Nomenclature of the dolphins, porpoises, and small whales: a review and guide to the early taxonomic literature

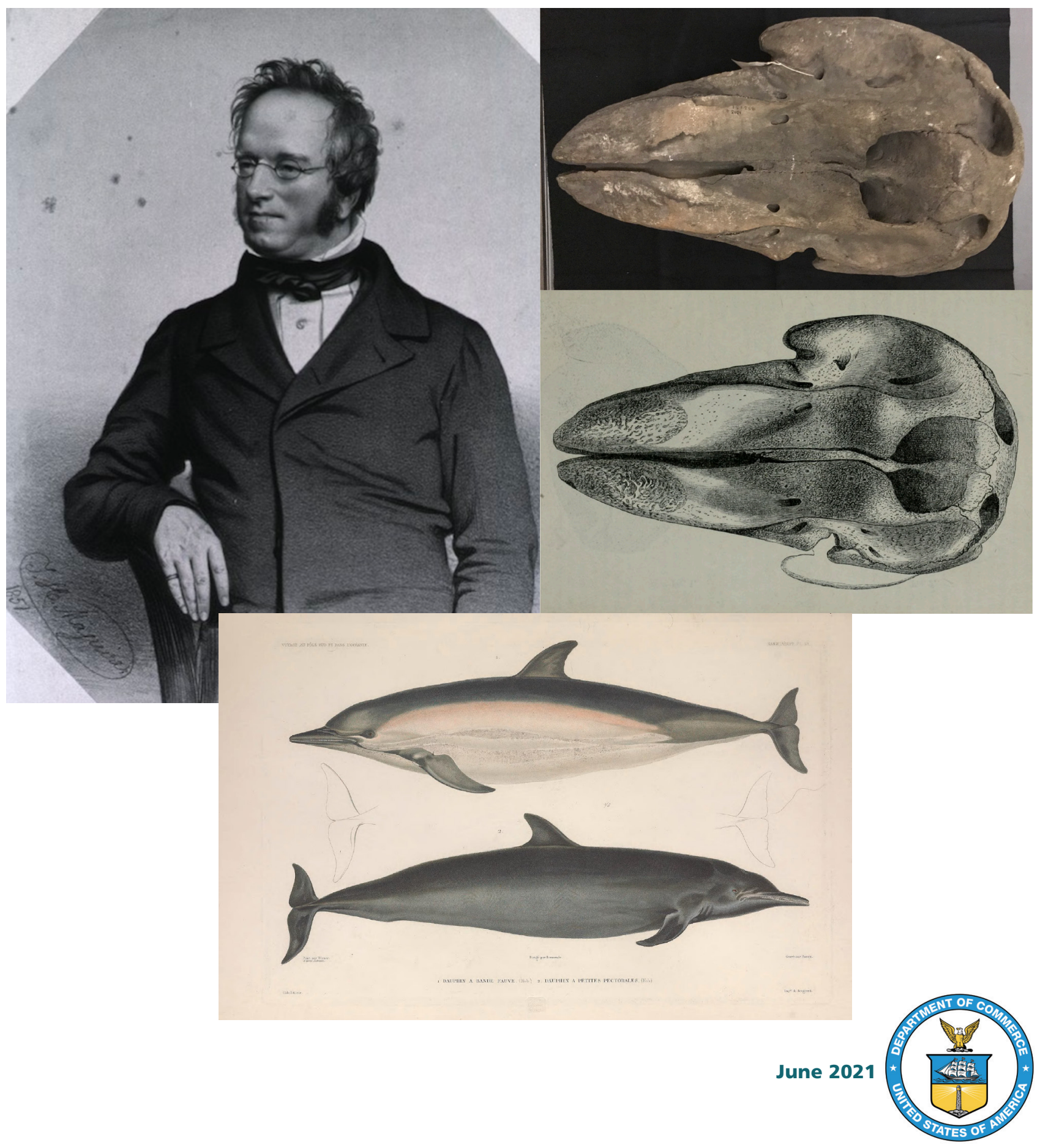




\section{U.S. Department of Commerce}

Gina M. Raimondo

Secretary of Commerce

\section{National Oceanic and Atmospheric Administration}

Richard W. Spinrad

Administrator

\section{National Marine Fisheries Service}

Janet Coit

Assistant Administrator for Fisheries

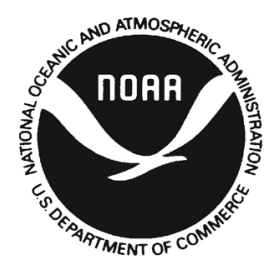

The NOAA Professional Paper NMFS (ISSN 1931-4590) series is published by the Scientific Publications Office, National Marine Fisheries Service, NOAA, 7600 Sand Point Way NE, Seattle, WA 98115.

The Secretary of Commerce has determined that the publication of this series is necessary in the transaction of the public business required by law of this Department. Use of funds for printing of this series has been approved by the Director of the Office of Management and Budget.

\section{NOAA Professional Papers NMFS}

\section{Scientific Editor \\ José I. Castro}

National Marine Fisheries Service, NOAA

263 13th Avenue South

Saint Petersburg, Florida 33701

\section{Associate Editor Cara Mayo}

National Marine Fisheries Service, NOAA

Scientific Publications Office

7600 Sand Point Way NE

Seattle, Washington 98115

\section{Managing Editor \\ Shelley Arenas}

National Marine Fisheries Service, NOAA

Scientific Publications Office

7600 Sand Point Way NE

Seattle, Washington 98115
The NOAA Professional Paper NMFS series carries peer-reviewed, lengthy original research reports, taxonomic keys, species synopses, flora and fauna studies, and dataintensive reports on investigations in fishery science, engineering, and economics. Copies of the NOAA Professional Paper NMFS series are available free in limited numbers to government agencies, both federal and state. They are also available in exchange for other scientific and technical publications in the marine sciences. Professional Papers are published online in PDF format at http://spo.nmfs.noaa.gov

NOTICE: This series was established in 2003 to replace the NOAA Technical Report NMFS series. 
NOAA Professional Paper NMFS 21

Nomenclature of the dolphins, porpoises, and small whales: a review and guide to the early taxonomic literature

Thomas A. Jefferson

June 2021 


\section{Cover image}

Portrait of John Edward Gray by Thomas Herbert Maguire (left, in public domain); photo and illustration of holotype of Globicephalus incrassatus (upper right); and illustration of dolphin specimens from Jacquinot and Pucheran (1853). All copyrights expired.

\section{Suggested reference}

Jefferson, Thomas A. 2021. Nomenclature of the dolphins, porpoises, and small whales: a review and guide to the early taxonomic literature. NOAA Professional Paper NMFS 21, 107 p. https://doi.org//10.7755/PP.21

\section{Online dissemination}

This report is posted online in PDF format at http://spo.nmfs.noaa.gov (click on Professional Papers link).

\section{Copyright law}

Although the contents of the Professional Papers have not been copyrighted and may be reprinted entirely, reference to source is appreciated.

\section{Proprietary products}

The National Marine Fisheries Service (NMFS) does not approve, recommend, or endorse any proprietary product or proprietary material mentioned in this publication. No reference shall be made to NMFS, or to this publication furnished by NMFS, in any advertising or sales promotion which would indicate or imply that NMFS approves, recommends, or endorses any proprietary product or proprietary material mentioned herein, or which has as its purpose an intent to cause directly or indirectly the advertised product to be used or purchased because of this NMFS publication.

\section{Disclaimer}

The findings and conclusions in this report are those of the author(s) and do not necessarily represent the views of the National Marine Fisheries Service (NOAA). 


\section{CONTENTS}

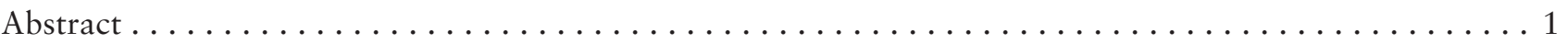

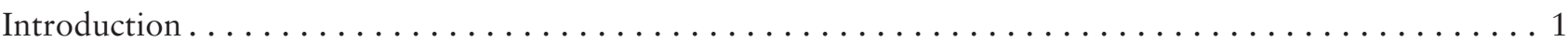

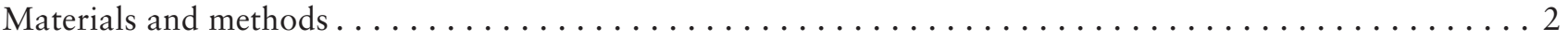

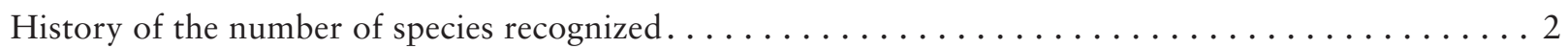

Examination and documentation of type specimens $\ldots \ldots \ldots \ldots \ldots \ldots \ldots \ldots \ldots \ldots \ldots$

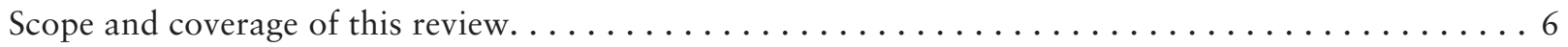

Review of the named species of dolphins, porpoises, and small whales $\ldots \ldots \ldots \ldots \ldots \ldots \ldots \ldots$

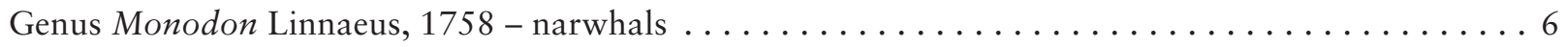

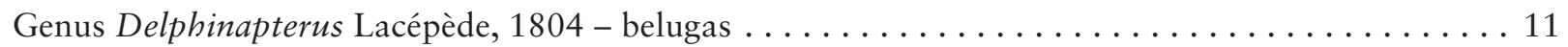

Genus Orcaella Gray, 1866 - Irrawaddy and snubfin dolphins . . . . . . . . . . . . . . 13

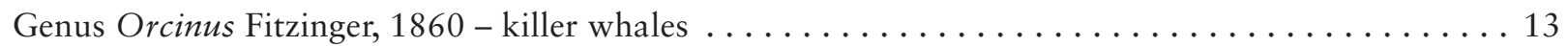

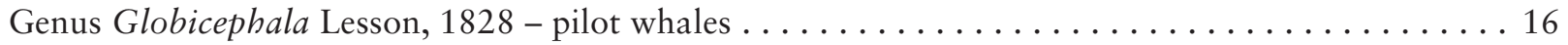

Genus Pseudorca Reinhardt, 1862 - false killer whales. . . . . . . . . . . . . . . . . . . . . . 19

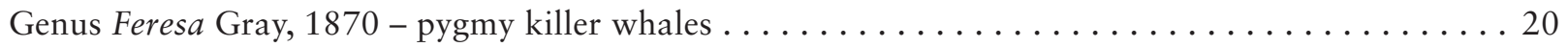

Genus Peponocephala Nishiwaki and Norris, 1966 - melon-headed whales . . . . . . . . . . 21

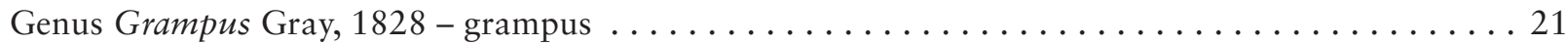

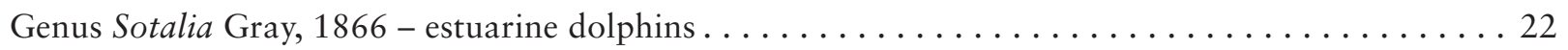

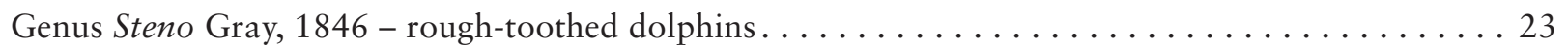

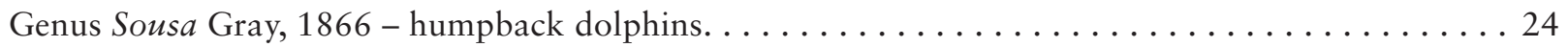

Genus Tursiops Gervais, 1855 - bottlenose dolphins . . . . . . . . . . . . . . . . . . . . 29

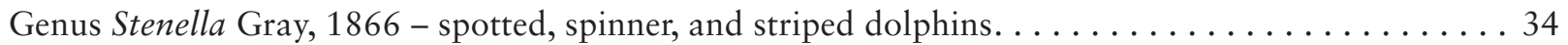

Genus Delphinus Linnaeus, 1758 - common dolphins . . . . . . . . . . . . . . . . . 40

Genus Lagenodelphis Fraser, 1956 - Fraser's dolphins . . . . . . . . . . . . . . . . . . . 45

Genus Lagenorhynchus Gray, 1846 - white-sided and white-beaked dolphins. . . . . . . . . . 45

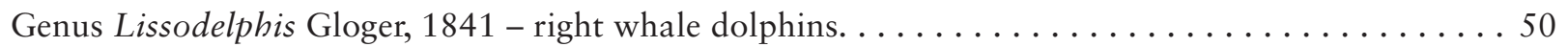

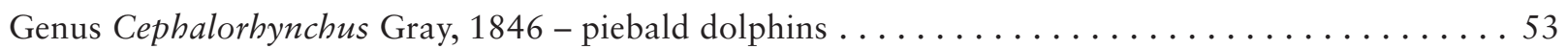

Genus Phocoenoides Andrews, 1911 - Dall's porpoises . . . . . . . . . . . . . . . . . . 55

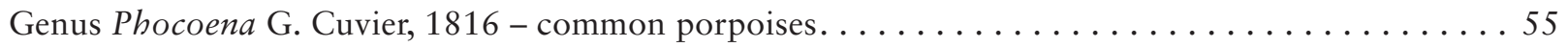

Genus Neophocaena Palmer, 1899 - finless porpoises. . . . . . . . . . . . . . . . 57

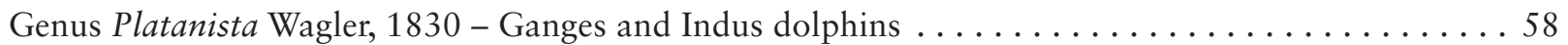

Genus Inia d'Orbigny, 1834 - Amazon river dolphins. . . . . . . . . . . . . . . . . . 59

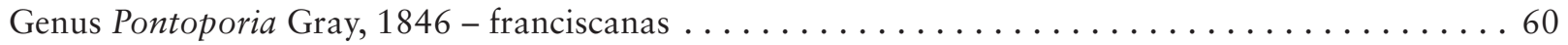

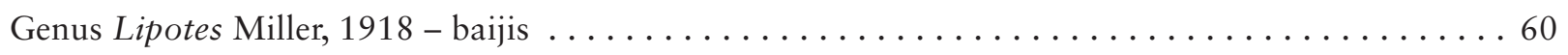

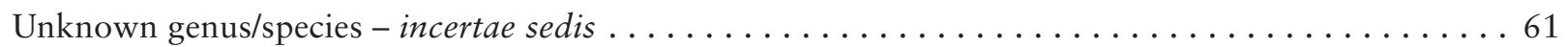

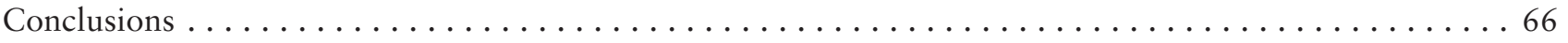

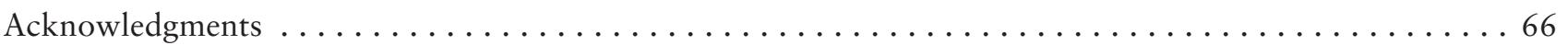

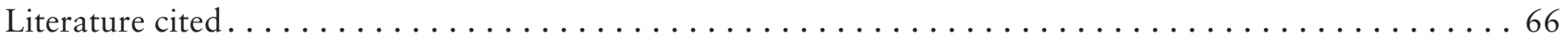

Appendix A: A note on interpreting the early taxonomic literature . . . . . . . . . . . . . 79

Appendix B: Short biographies of the major describers of delphinoid cetaceans $\ldots \ldots \ldots \ldots \ldots \ldots 8$

Appendix C: John Edward Gray (1800-1875): his contributions to marine mammal biology . . . . . . . 90 


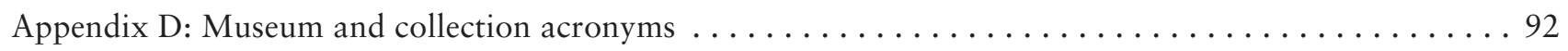

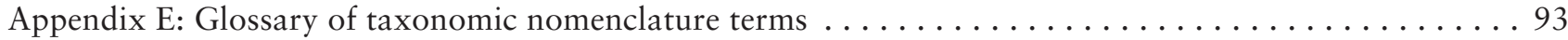

Appendix F: Species names originating in Schreber's Die Säugthiere in Abbildungen . . . . . . . . . 95

Appendix G: List of named species of dolphins, porpoises, and small whales . . . . . . . . . . . 97 
Abstract-The taxonomy of several genera of small cetaceans has been confused for decades or even centuries. At least 358 species of dolphins, porpoises, and small whales have been given names, yet only 50 of these are currently recognized as valid species; the vast majority of the rest are junior synonyms. Recent taxonomic revisions of some genera have clarified things, but there are others that await taxonomic revision, which will probably recommend generic recombinations and new or resurrected species. As new taxonomic studies are resurrecting old species and sometimes describing new ones, an understanding of the available names is crucial to this task. This monograph comprehensively reviews all 358 valid and invalid species of dolphins, porpoises, and small whales; documents their type specimens; summarizes the history of each name; and assigns a status to each. In addition, appendices discuss the early taxonomic literature, historical notes, and museum acronyms, and provide a glossary of relevant taxonomic terms. Ultimate goals are to help identify as many of the nomina dubia as possible, and to facilitate the inclusion of data and material (both morphological and molecular) from relevant type specimens into future taxonomic studies.

\title{
Nomenclature of the dolphins, porpoises, and small whales: a review and guide to the early taxonomic literature
}

\author{
Thomas A. Jefferson \\ Email address: sclymene@aol.com \\ Clymene Enterprises \\ 13037 Yerba Valley Way \\ Lakeside, California 92040
}

\section{Introduction}

In 1966, Phillip Hershkovitz published his review of nomenclature of extant species of cetaceans, Catalog of Living Whales. This impressive work was a comprehensive review of virtually every nominal species of whale, dolphin, or porpoise, and it has been an invaluable resource ever since, remaining indispensible to anyone wanting to investigate the history of cetacean taxonomic nomenclature or to construct a synonymy for these animals. After more than 54 years, however, Hershkovitz (1966) is dated, and while it is exceedingly thorough and comprehensive, it is not without errors.

With the advent and recent maturity of molecular phylogenetics in the past two decades, great strides have been made in our understanding of cetacean taxonomy and systematics. We have gone from a conservative phase of lumping to a more liberal phase of profound splitting. New species are being discovered, and old species (and even genera) that had been relegated to synonymy for decades or centuries are being resurrected with surprising frequency (SMM, 2020). This trend is likely to continue, and perhaps even intensify, over the next couple of decades. Taxonomic challenges that once seemed insurmountable are now feasible. For instance, it's no longer necessary to compile large sets of morphometric samples (primarily skulls), which were difficult to collect and maintain. We now only need to collect tiny bits of tissue (skin, muscle, bone, etc.) or even blood or feces (though permit issues can complicate matters). Although morphology remains important for making taxonomic decisions, we don't need to have access to dead specimens and can obtain samples from living animals. It is now possible to develop sampling programs, using environmental-DNA or biopsy sampling protocols, which will provide the large numbers of samples needed to address these taxonomic challenges (see Ma et al., 2016).

Nowhere has the problem of untangling the evolutionary history and developing an accurate systematic framework been more difficult than with the "dolphin-like" cetaceans (dolphins, porpoises, and small monodontid whales). The taxonomy of several genera of small cetaceans is still unresolved (see Perrin et al., 2013). Recent taxonomic revisions of some genera (e.g., Orcaella, Sotalia, Sousa, Lagenorhynchus) have clarified things to a great extent (Beasley et al., 2005; Caballero et al., 2007; Jefferson and Rosenbaum, 2014; Vollmer et al., 2019), but there are still other genera that await taxonomic revision, and which are sure to recommend generic recombinations and new or resurrected species (e.g., Orcinus, Tursiops, Stenella, Platanista). 


\section{Table 1}

List of exploring expeditions from which delphinoid species were described.

\begin{tabular}{|c|c|c|c|c|c|c|c|}
\hline \multirow[b]{2}{*}{ Ship name(s) } & \multirow[b]{2}{*}{ Nation } & \multirow[b]{2}{*}{ Years } & \multirow[b]{2}{*}{ Destination } & \multirow[b]{2}{*}{ Leader } & \multicolumn{2}{|c|}{$\begin{array}{c}\text { No. of } \\
\text { species described }\end{array}$} & \multirow[b]{2}{*}{ References } \\
\hline & & & & & Valid & Invalid & \\
\hline $\begin{array}{l}\text { Prinz Karl } \\
\text { L'Uraine and } \mathrm{La}\end{array}$ & Sweden & $1750-1752$ & China & Unknown & 1 & 0 & Osbeck, 1771 \\
\hline Physicienne & France & $1817-1820$ & Global & L. Freycinet & 1 & 2 & Quoy and Gaimard, 1824 \\
\hline La Coquille & France & $1822-1825$ & Global & L. I. Duperrey & 0 & 7 & Lesson, 1826; Lesson and Garnot, 1827 \\
\hline l'Astrolabe & France & $1826-1829$ & Antarctica & J. D. d'Urville & 0 & 2 & Quoy and Gaimard, 1830; Fischer, 1876 \\
\hline La Meuse & France & $1826-1833$ & S. America & N/A & 1 & 0 & d'Orbigny and Gervais, 1847 \\
\hline $\begin{array}{l}\text { H.M.S. Beagle } \\
\text { l'Astrolabe and }\end{array}$ & Great Britain & $1831-1836$ & S. America & R. Fitzroy & 0 & 1 & Waterhouse, 1838a; Darwin, 1860 \\
\hline $\begin{array}{l}\text { La Zelee } \\
\text { USS Vincennes }\end{array}$ & France & $1837-1840$ & Antarctica & J. D. d'Urville & 0 & 4 & Jacquinot and Pucheran, 1853 \\
\hline $\begin{array}{l}\text { and five others } \\
\text { H.M.S. Erebus }\end{array}$ & United States & $1838-1842$ & Global & C. Wilkes & 2 & 5 & Peale, 1849; Cassin, 1858 \\
\hline$\&$ Terror $^{1}$ & Great Britain & $1839-1843$ & Antarctica & J. C. Ross & 5 & 24 & Gray, 1846; Ross, 1982 \\
\hline N/A & France & $1843-1847$ & S. America & F. Castelnau & 0 & 1 & Gervais, 1855 \\
\hline N/A & British India & 1868,1875 & S.E. Asia & $\begin{array}{l}\text { E. B. Sladen and } \\
\text { H. Browne }\end{array}$ & 0 & 1 & Anderson, 1879 \\
\hline Terra Nova & Great Britain & 1910 & Antarctica & R. F. Scott & 0 & 1 & Lillie, 1915 \\
\hline
\end{tabular}

${ }^{1} \mathrm{Few}$, if any, of the species described in Gray's (1846) monograph were actually collected on this expedition.

Impediments to such resolution include the challenge of identifying proper nomenclature when taxonomic revisions are made and when new taxa are proposed. There are currently $c a .360$ nominal species of "delphinoid" cetaceans (most described in the nineteenth century), yet only 50 of these are currently recognized as valid species (SMM, 2020; Table 1). Many of the remainder of these names are currently considered to be nomina dubia (i.e., of questionable identity), yet information in the literature and examination of the relevant type specimens have often not been adequately pursued.

The set of nominal species that are currently not recognized as valid is a tangled mess, with many names based on a single specimen, often a skull or bone. Often there is little or no information on the external appearance, or worse yet, a description from an atsea sighting outlining body shape and color pattern, but providing no clues on the skeletal anatomy. Such was common practice for the naturalists and biologists of the nineteenth century, during zoology's great age of discovery (see True, 1889). Far-flung expeditions brought back biological material for the description of many new species (Table 2), but the extent of geographic variation within a species was generally not recognized. Many species were described as different simply because a specimen was a bit larger or smaller, or had more or less teeth, or sometimes just because it came from a different ocean basin.

In 2018, I felt the need for an updated, critical review of the nomenclature of delphinoid cetaceans. This project had as its main objective reviewing the status of all nominal species of dolphins, porpoises, and small whales, and documenting their type specimens. Ultimate goals were to identify as many of the nomina dubia as possible, and to facilitate the inclusion of data and material (both morphological and molecular) from relevant type specimens into future taxonomic studies.

\section{Materials and methods}

\section{History of the number of species recognized}

From Linneaus' initial four species described in 1758, the number of species of delphinoid cetaceans recognized expanded greatly in the middle of the nineteenth century (Fig. 1). This was due to the hundreds of specimens brought back from the various English, French, and American voyages of discovery, mostly focusing on the Southern Hemisphere and Antarctic. Examples were the French voyages of La Coquille (1822-1825 - Lesson, 1826; Lesson and Garnot, 1827), and the Astrolabe and Zelee (1826-1829, 1837-1840 - Quoy and Gaimard, 1830; Jacquinot and Pucheran, 1853); 
Table 2

List of species covered in this review.

\begin{tabular}{|c|c|c|}
\hline Common name & Scientific name & Authority \\
\hline Narwhal & Monodon monoceros & Linnaeus, 1758 \\
\hline Beluga or white whale & Delphinapterus leucas & Pallas, 1776 \\
\hline Australian snubfin dolphin & Orcaella heinsohni & Beasley et al., 2005 \\
\hline Irrawaddy dolphin & Orcaella brevirostris & Owen in Gray, $1866 b$ \\
\hline Killer whale & Orcinus orca & Linnaeus, 1758 \\
\hline Long-finned pilot whale & Globicephala melas & Traill, 1809 \\
\hline Short-finned pilot whale & Globicephala macrorhynchus & Gray, 1846 \\
\hline False killer whale & Pseudorca crassidens & Owen, 1846 \\
\hline Pygmy killer whale & Feresa attenuata & Gray, 1874 \\
\hline Melon-headed whale & Peponocephala electra & Gray, 1846 \\
\hline Risso's dolphin & Grampus griseus & G. Cuvier, 1812 \\
\hline Tucuxi & Sotalia fluviatilis & Gervais and Deville in Gervais, 1853 \\
\hline Guiana dolphin & Sotalia guianensis & P. J. Van Beneden, 1864 \\
\hline Rough-toothed dolphin & Steno bredanensis & Lesson, 1828 \\
\hline Indo-Pacific humpback dolphin & Sousa chinensis & Osbeck, 1765 \\
\hline Indian Ocean humpback dolphin & Sousa plumbea & G. Cuvier, 1829 \\
\hline Atlantic humpback dolphin & Sousa teuszii & Kükenthal, 1892 \\
\hline Australian humpback dolphin & Sousa sahulensis & Jefferson and Rosenbaum, 2014 \\
\hline Common bottlenose dolphin & Tursiops truncatus & Montagu, 1821 \\
\hline Indo-Pacific bottlenose dolphin & Tursiops aduncus & Hemprich and Ehrenberg, 1832 \\
\hline Pantropical spotted dolphin & Stenella attenuata & Gray, 1846 \\
\hline Atlantic spotted dolphin & Stenella frontalis & G. Cuvier, 1829 \\
\hline Spinner dolphin & Stenella longirostris & Gray, 1828 \\
\hline Clymene dolphin & Stenella clymene & Gray, 1850 \\
\hline Striped dolphin & Stenella coeruleoalba & Meyen, 1833 \\
\hline Common dolphin & Delphinus delphis & Linnaeus, 1758 \\
\hline Fraser's dolphin & Lagenodelphis hosei & Fraser, 1956 \\
\hline White-beaked dolphin & Lagenorhynchus albirostris & Gray, 1846 \\
\hline Atlantic white-sided dolphin & Lagenorhynchus acutus & Gray, 1828 \\
\hline Pacific white-sided dolphin & Lagenorhynchus obliquidens & Gill, 1865 \\
\hline Dusky dolphin & Lagenorhynchus obscurus & Gray, 1828 \\
\hline Hourglass dolphin & Lagenorhynchus cruciger & Quoy and Gaimard, 1824 \\
\hline Peale's dolphin & Lagenorhynchus australis & Peale, 1849 \\
\hline Northern right whale dolphin & Lissodelphis borealis & Peale, 1849 \\
\hline Southern right whale dolphin & Lissodelphis peronii & Lacépède, 1804 \\
\hline Commerson's dolphin & Cephalorhynchus commersonii & Lacépède, 1804 \\
\hline Hector's dolphin & Cephalorhynchus hectori & P. J. Van Beneden, 1881 \\
\hline Chilean dolphin & Cephalorhynchus eutropia & Gray, 1846 \\
\hline Heaviside's dolphin & Cephalorhynchus heavisidii & Gray, 1828 \\
\hline Dall's porpoise & Phocoenoides dalli & True, 1885 \\
\hline Harbor porpoise & Phocoena phocoena & Linnaeus, 1758 \\
\hline Spectacled porpoise & Phocoena dioptrica & Lahille, 1912 \\
\hline Burmeister's porpoise & Phocoena spinipinnis & Burmeister, 1865a \\
\hline Vaquita & Phocoena sinus & Norris and McFarland, 1958 \\
\hline Indo-Pacific finless porpoise & Neophocaena phocaenoides & G. Cuvier, 1829 \\
\hline Narrow-ridged finless porpoise & Neophocaena asiaeorientalis & Pilleri and Gihr, 1972a \\
\hline South Asian river dolphin & Platanista gangetica & Lebeck, 1801 \\
\hline Boto or Amazon river dolphin & Inia geoffrensis & Blainville in Desmarest, 1817 \\
\hline Franciscana & Pontoporia blainvillei & Gervais and d'Orbigny, 1844 \\
\hline Baiji or Yangtze river dolphin & Lipotes vexillifer & Miller, 1918 \\
\hline
\end{tabular}

and the British voyages of the H.M.S. Erebus and Terror (1839-1843 - Gray, 1846; Ross, 1982) and Beagle (1832-1836 - Waterhouse, 1838a; Darwin, 1860). The United States contributed the U.S. Exploring Expedition (1838-1842), a global voyage of discovery involving six vessels, the Sea Gull, Vincennes, Flying Fish, Peacock, Porpoise, and Relief (Peale, 1849; Cassin, 1858). The specimens brought back from these far-flung expeditions provided naturalists and museum curators a wealth of previously unknown cetacean specimens 


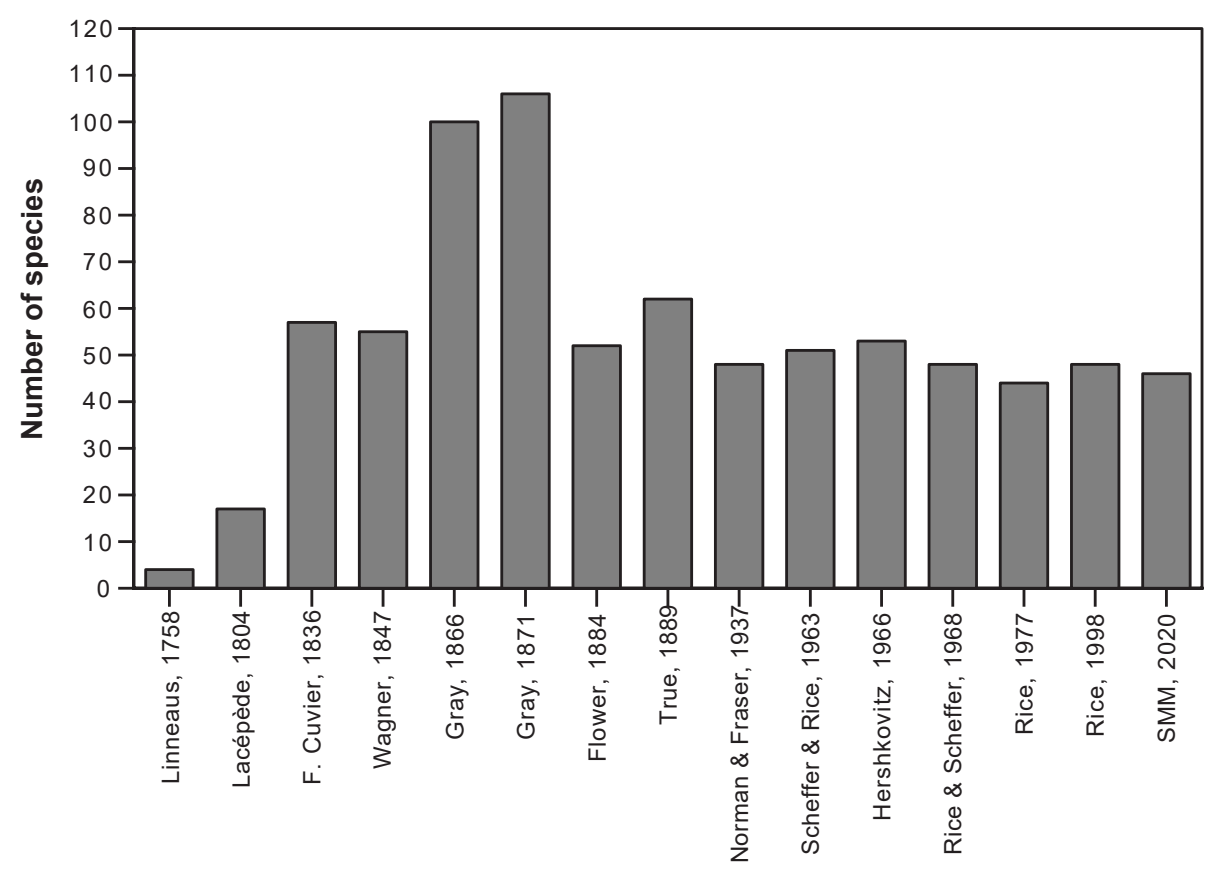

Reference

Figure 1

The number of delphinoid species recognized by various authors from Linnaeaus to present, listed chronologically by reference date. Gray's propensity toward splitting is obvious here, as he recognized many more species than authors before or after him did.

(Table 2). The benefits to our knowledge of cetacean diversity were undeniable. However, the huge influx of materials and often incomplete or erroneous documentation also caused great confusion, resulting in the description of many nominal species that have not survived and have been relegated to junior synonymy. The result has been a tangled mess of names that must be sorted through new taxonomic work (see Hershkovitz, 1966 for a discussion). Appendix A provides a guide to interpreting the early taxonomic literature.

The peak of this heyday was in the 1840s through 1860s, during what Perrin (2009) called the "great Victorian Radiation" (Fig. 2). During these three decades, $41 \%$ (143/352) of all species of dolphins and porpoises were described. Most of the authors of these species descriptions were British or French, and while there were many naturalists who only described one or a couple of species, there were a few prolific scientists who described large numbers of species (Fig. 3; Appendix B). The most famous and important of these was John Edward Gray, who worked at the British Museum of Natural History from 1816 to 1875 and became its curator. He single-handedly described no less than 73 species of delphinoid cetaceans $(21 \%$ of all species described, and more than three times as many as any other author), in addition to many species of other plant and animal taxa. The highly prolific Gray was also largely responsible for the two peaks in delphinoid species described in the 1840s (Zoology of the Voyage of the H.M.S. Erebus and Terror; Gray, 1846) and 1860s (Catalogue of Seals and Whales in the British Museum; Gray, 1866a) - see Fig. 2. Gray's extensive contributions to the field of marine mammalogy, and the resulting problems they caused, are reviewed in Appendix C.

\section{Examination and documentation of type specimens}

I contacted museums that had been reported in the literature as having type specimens, in order to determine their current status. However, it was not always possible to obtain the desired information. I visited museums that maintain collections of delphinoid cetacean specimens and hold significant numbers of type specimens (see Appendix D for a list of museum and collection acronyms). At each museum visited, I queried the relevant curators about what delphinoid type specimens 


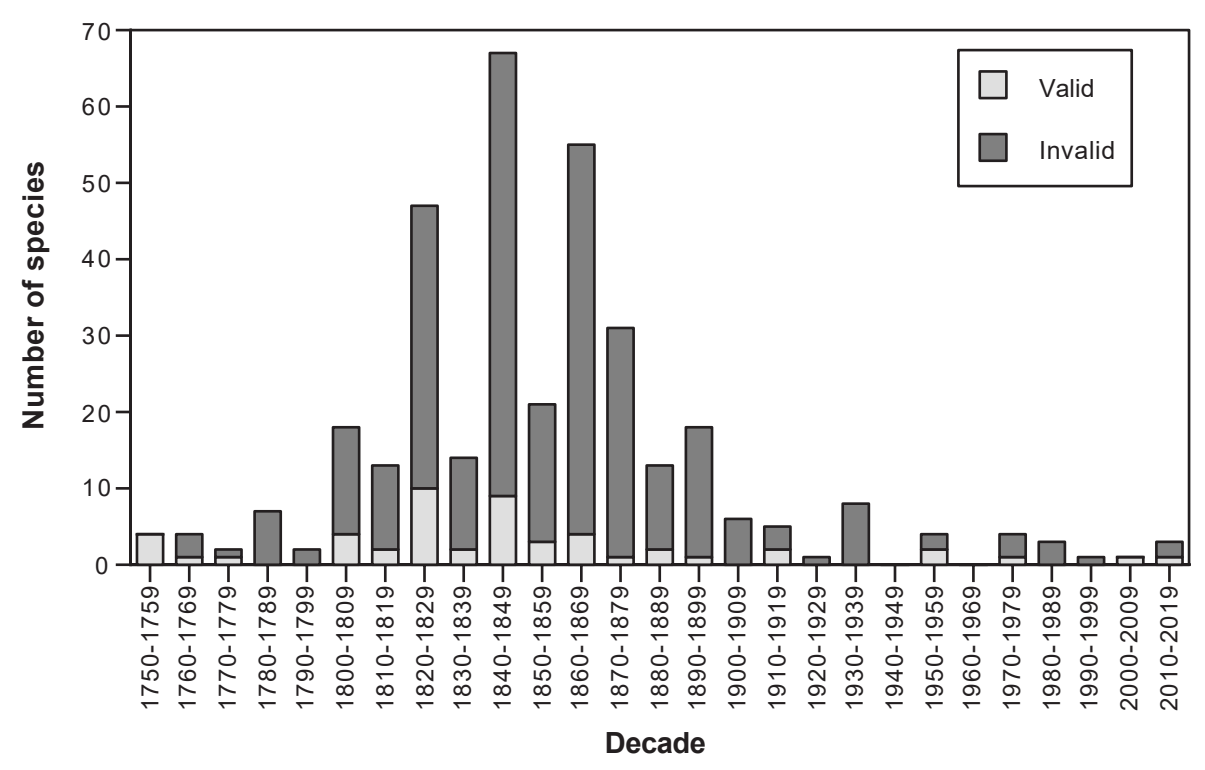

Figure 2

The number of delphinoid species described by decade. The 1820 s through the 1860 s were the heyday of species description, what Perrin (2009) called the "Great Victorian Radiation.”

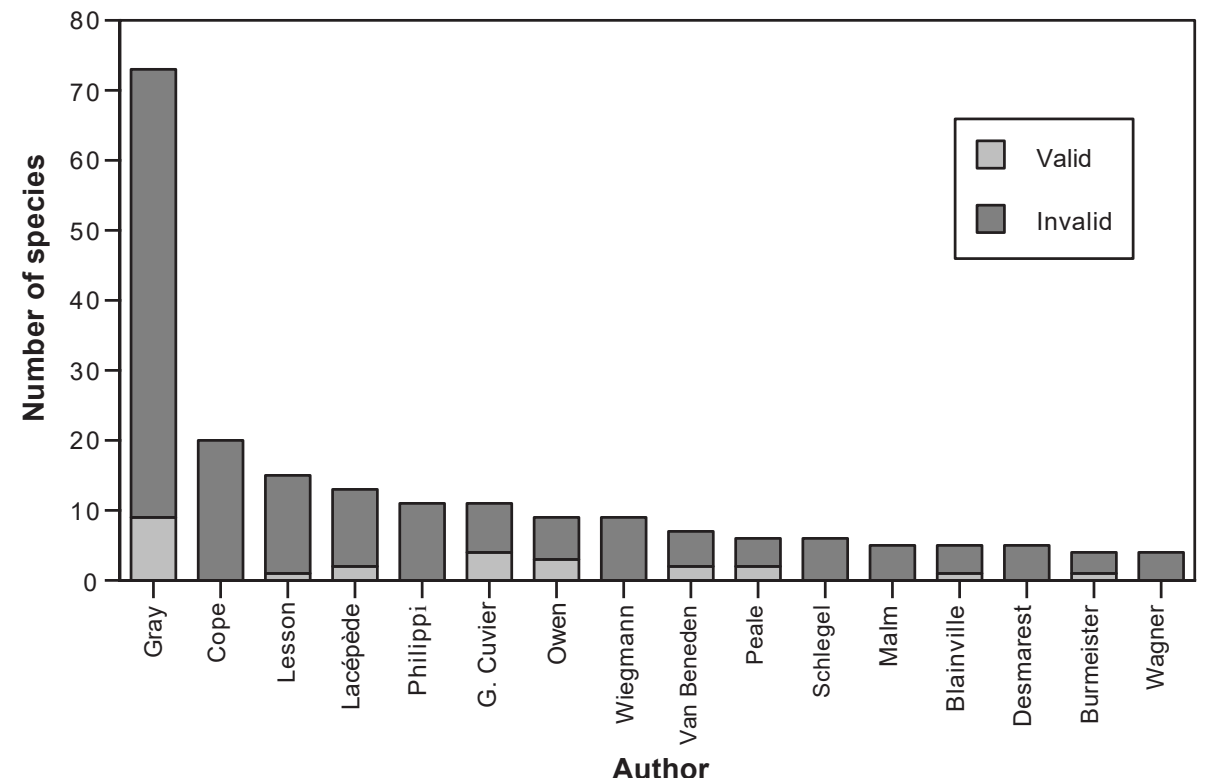

Figure 3

The number of delphinoid species described by authors, showing Gray's enormous contribution to the description of species in this group. 
the institution maintained. Then, I attempted to document each type specimen identified. I collected the following kinds of information on each:

1) Species identification - Regardless of the original identification, each specimen was examined to determine the identification to species level, using the list of recognized marine mammal species maintained and regularly updated by the Society for Marine Mammalogy's Committee on Taxonomy (SMM, 2020).

2) Nature of material and condition - Documentation was made of the kind of material comprising the type (e.g., skull, cranium, postcranial skeleton, stuffed skin, etc.), and the condition that it was in (e.g., undamaged, damaged, stored in alcohol, fixed in formalin, etc.).

3) History - The museum's records and tags on specimens were consulted for information on the collector, collection details, and history of the specimen, to see if that information matched what is recorded in published literature.

4) Photographs - Standard photographs were taken of each type specimen; for skulls, dorsal, ventral, lateral, and mandible views were taken.

5) Skull measurements - An abbreviated set of standardized measurements was taken on skulls with vernier calipers (anthropometer), to allow for better identification and comparison, and to evaluate adulthood. Measurements that I took of type specimens are presented in Table 3.

For certain specimens, generally when the identity was not known, I asked the curatorial staff if a small sample of tissue could be collected for use in molecular genetic studies.

\section{Scope and coverage of this review}

This paper attempts to review and evaluate every named species of recent "dolphin-like" cetacean (here defined as members of the families Delphinidae, Phocoenidae, Monodontidae, Platanistidae, Iniidae, Pontoporiidae, and Lipotidae). Although it is now known that platanistid river dolphins do not have a close evolutionary relationship with the other species covered in this review (see McGowen et al., 2020), I have chosen to include them because their nomenclatorial history is closely intertwined with that of the other species.

By nominal or named species, I mean each species name that was intended as a new binomen, whether it was for a species perceived by the describer as new, or was intended as a replacement name (see Appendix E for a glossary of taxonomic and nomenclatorial terms). However, with few exceptions, I do not include names from pre-Linnaean (1758) works, generic recombinations, subspecies or variety names, emendations (justi- fied or unjustified), or various spelling errors, such as printing errors, or slips of the pen (i.e, lapsus calami). Thus, I make no attempt to produce full synonymies for the species covered. That will be left up to specialists on those species.

Published type descriptions of all relevant species were obtained and examined, either in hardcopy or electronic (pdf) form. The database Biodiversity Heritage Library (https://www.biodiversitylibrary.org/) was invaluable in this endeavor. With the exception of English, I am not fluent in the languages that were used to describe many of the species in earlier days (e.g., French, German, Spanish, Danish, Dutch), and the website GoogleTranslate (https://translate.google.com/) was used to provide a rough translation so that relevant details could be extracted. I made use of published synonymies such as those in the Mammalian Species accounts (https://academic.oup.com/mspecies) and Hershkovitz's catalog of whales (Hershkovitz, 1966), but also attempted to go back to each primary reference to independently confirm details and identifications.

The appendices cover various topics of relevance to the review, but which would disrupt the flow of the document if not moved to separate sections (Appendix $F$ provides a summary of the results of an exhaustive search for information on how to cite and reference relevant sections of Schreber's Säugthiere, an important early reference). The Fourth Edition of the International Code of Zoological Nomenclature (ICZN, 1999) was used as the nomenclatorial standard throughout. The taxonomic scheme used in this review is the latest version of the Society for Marine Mammalogy's Committee on Taxonomy webpage (SMM, 2020). Published taxonomic revisions (such as that by Vollmer et al., 2019) have not been incorporated, unless accepted by the Committee on Taxonomy.

\section{Review of the named species of dolphins, porpoises, and small whales}

\section{Genus Monodon Linnaeus, 1758 - narwhals Monodon monoceros Linnaeus, 1758 - narwhal Monodon monoceros Linnaeus, 1758}

This was the first of 12 species of cetaceans described by Linnaeus (1758) in his 10th edition of Systema Naturae, the starting point of our modern system of binomial nomenclature. No type specimen was collected (the name was based on the narwhal, Norwegian for "corpse whale," known to ancient whalers and mariners), but Linnaeus stated that the species had a single tooth in the upper jaw, and was found in the oceans of America and Europe. This is the senior synonym and valid name of the narwhal. 


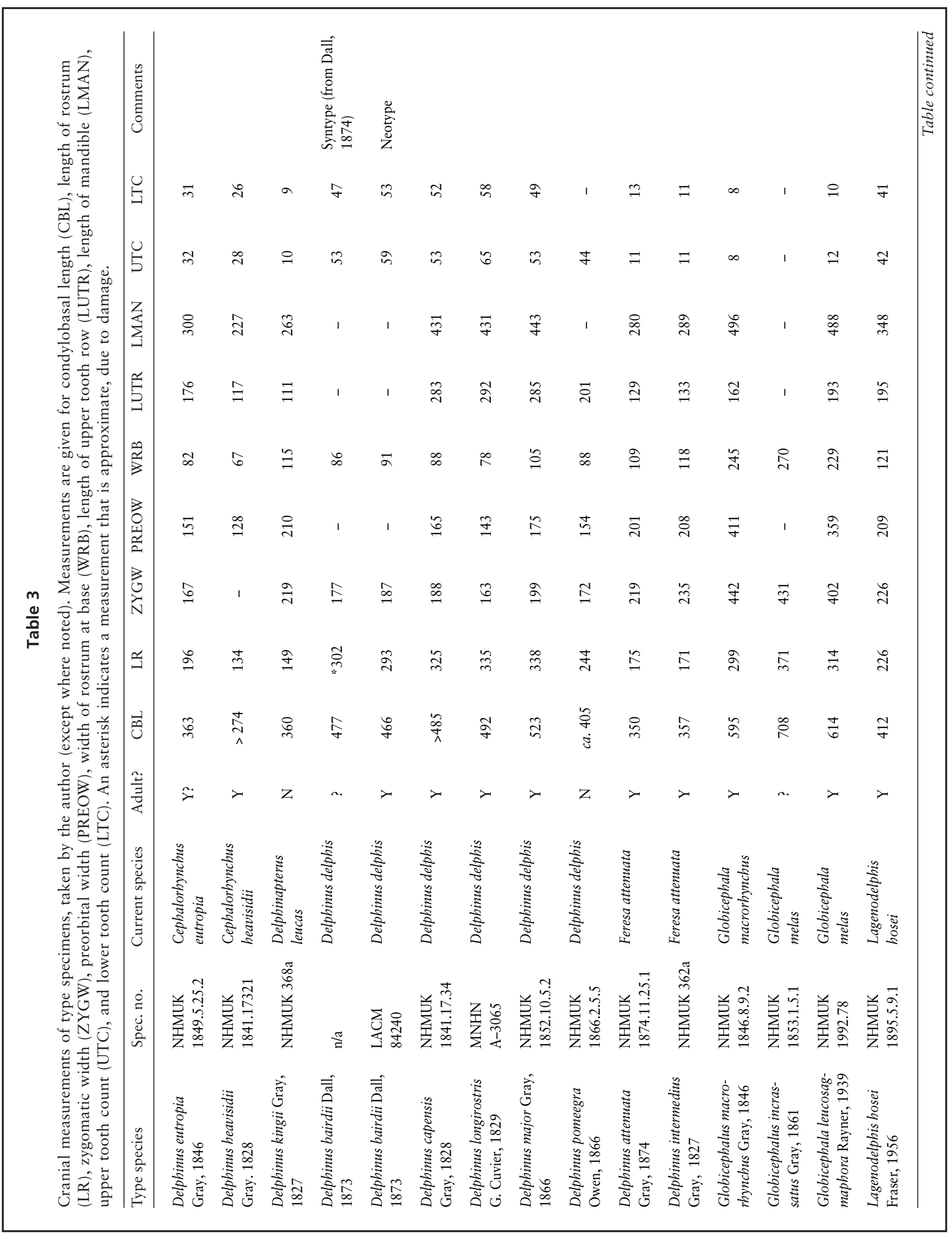




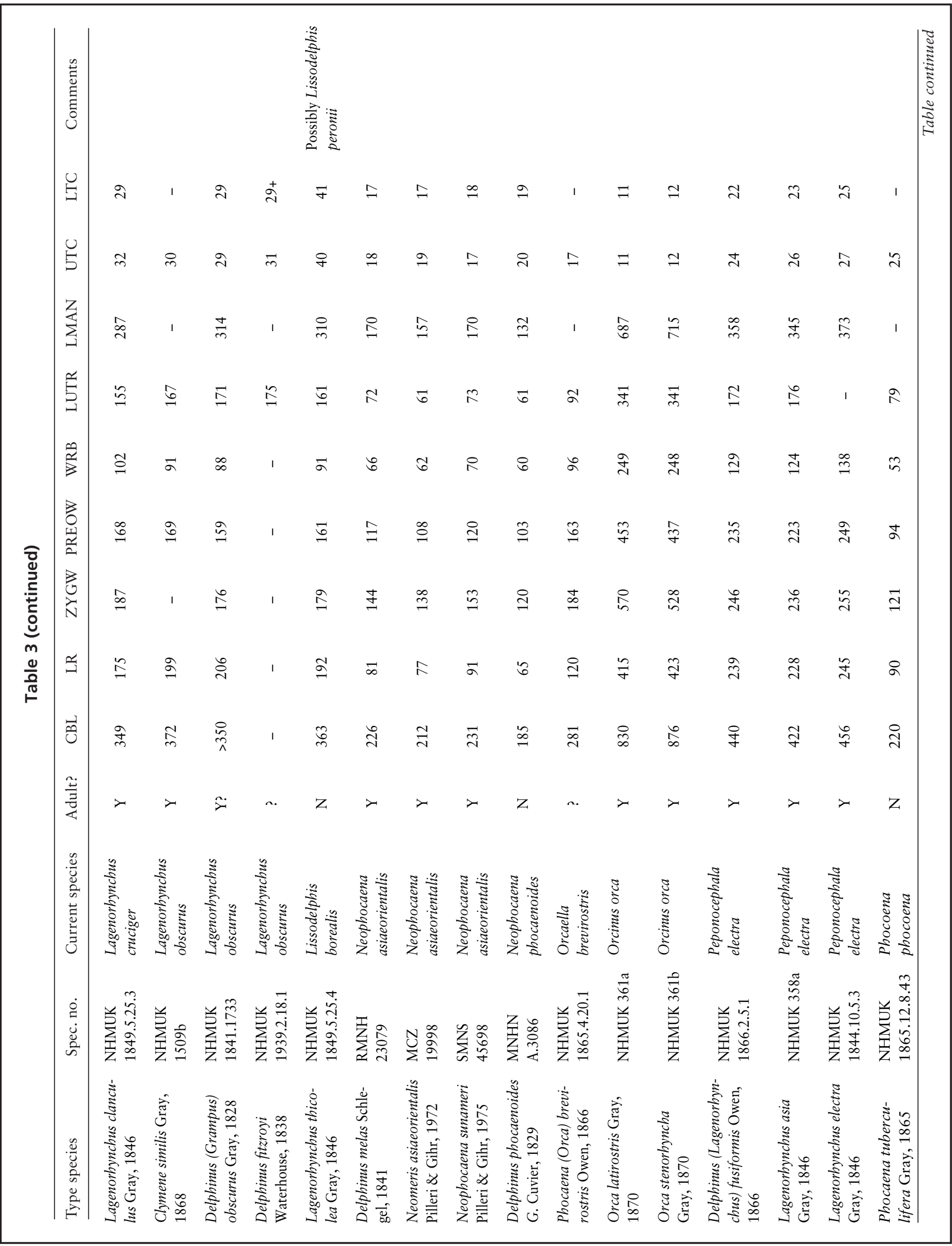




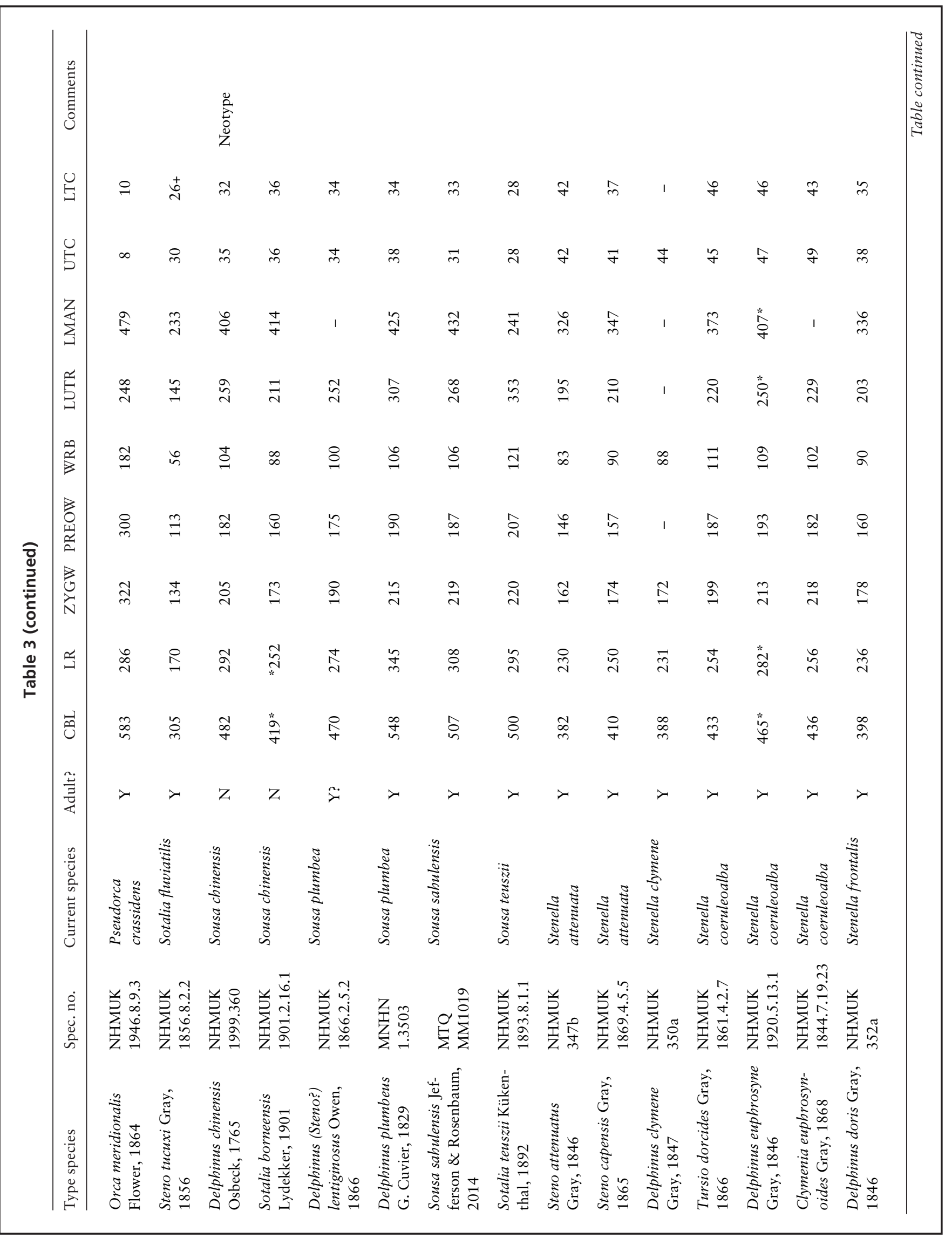




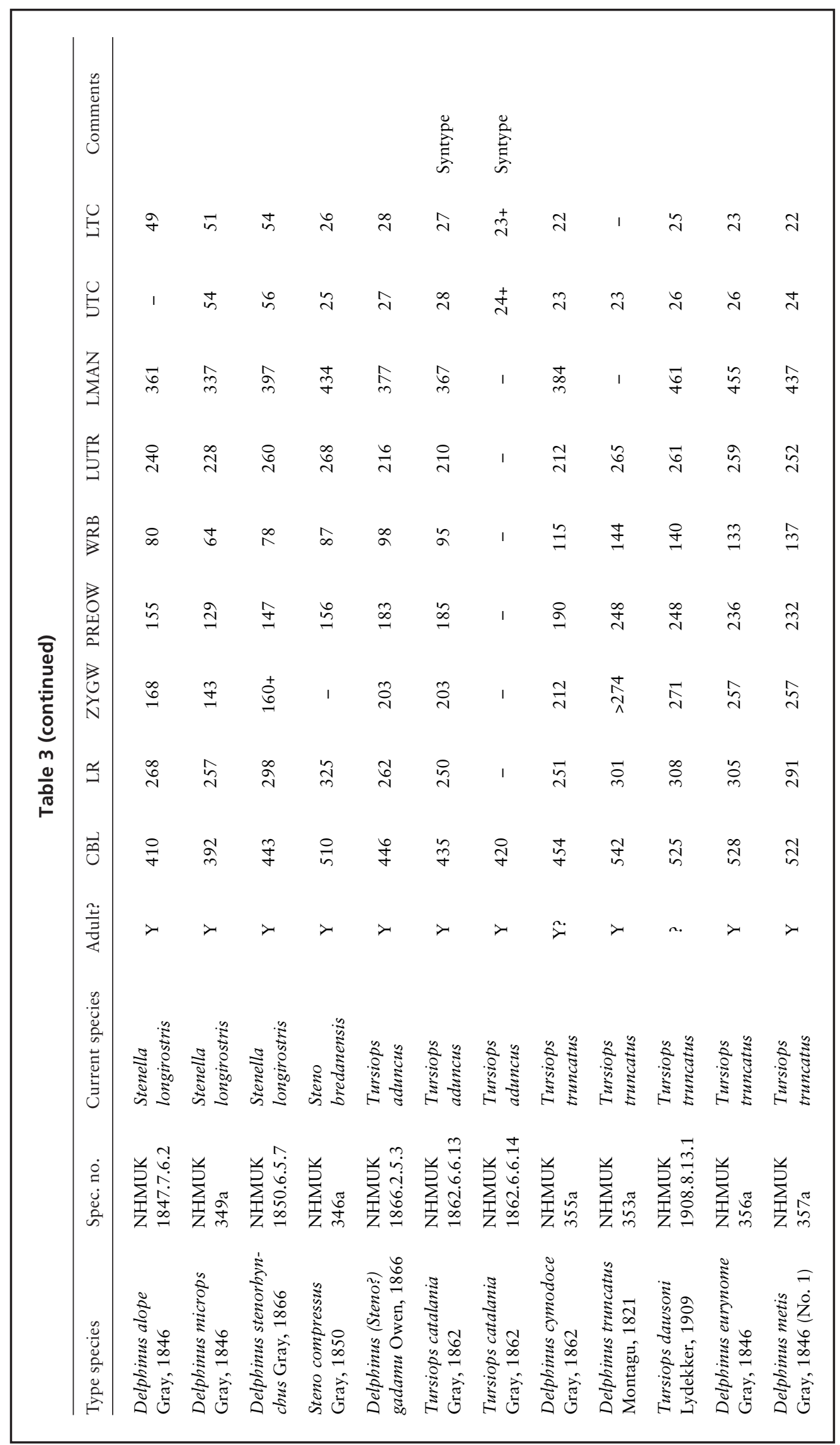




\section{Ceratodontis ceratodon Brisson, 1762}

In a short, but fairly-detailed account, Brisson describes the narwhal under this name. The type locality was the seas around Iceland, Greenland, and Davis Strait, although apparently no type specimen was collected. The name is now considered to be a junior synonym of Monodon monoceros.

\section{Monodon narwhal Blumenbach, 1779}

Blumenbach's short account uses the name Monodon narwhal for a cetacean with a long, straight spiral tooth. The type locality is unknown and it is not believed that a type specimen was obtained. The name is now considered to be a junior synonym of Monodon monoceros.

\section{Monodon narhval Borowski, 1781}

While some might consider this a new name, Monodon narbval appears to be simply an emendation of Blumenbach's (1779) Monodon narwhal. The account is rather detailed, but with no figures. This is a junior synonym of Monodon monoceros.

\section{Narwalus vulgaris Lacépède, 1804}

Lacépède's description of Narwalus vulgaris (apparently a new name for Monodon monoceros) is long on dramatic imagery, but short on details of the unique characters of this species (other than describing the tusk). The illustration of the form of the animal (plate 4, fig. 3) leaves no doubt about the identity of this nominal species. The type locality is unknown, and there was no type specimen collected. This is a junior synonym of Monodon monoceros.

\section{Narwalus microcephalus Lacépède, 1804}

Lacépède considered this a different species of narwhal, much smaller in size than the typical species, Narwalus vulgaris. The type locality was Boston (Lincolnshire, England), but it is unknown if a specimen was deposited into any collection. There are two illustrations of this species in his account (plate 5, fig. 2 and plate 9, fig. 1; the latter shows an animal with two tusks), which clearly indicate the species to be what we now consider to be the single species of narwhal, and the name is therefore a junior synonym of Monodon monoceros.

\section{Narwalus andersonianus Lacépède, 1804}

This short account by Lacépède describes what he considered a third narwhal species, one with very smooth tusks (these were probably older individuals, with the tusks smoothed by wear). The type locality is the Elbe River (presumably near its mouth in Germany), but it appears that no type specimen was deposited. The name is considered a junior synonym of Monodon monoceros.

\section{Ceratodon monodon Pallas, 1811}

Pallas's Ceratodon monodon is apparently a renaming of Monodon monoceros. The account is fairly short, and there is no illustration of this species among his plates. Reeves and Tracey (1980) mention a type locality from the coast of Siberia. The name is considered a junior synonym of Monodon monoceros.

\section{Tachynices megacephalus Brookes, 1828}

In the catalog of Joshua Brookes' personal zoological collection, he listed seven specimens of this species under this name, which was apparently a renaming of Monodon monoceros. The description of the specimens and the mention of "tusks" make it quite clear what species he was referring to, even though there are no figures. The Brookes collection was later purchased by the RMNH in Leiden, and it is unknown if these specimens still reside in that collection. The name is a junior synonym of Monodon monoceros.

\section{Genus Delphinapterus Lacépède, 1804 - belugas \\ Delphinapterus leucas (Pallas, 1776) - beluga or white whale}

\section{Cetus albicans Brisson, 1762}

This short description by Brisson of a white whale (le chachalot blanc) found in the Davis Strait and vicinity ("Baye Meridionale, appellee Sud-Bucht") appears to have been largely overlooked in recent times. Brisson had earlier described this species in 1756, but that was pre-Linnaean. Brisson's species was said to be similar to the narwhal and about 15-16 feet in length (4.6$4.9 \mathrm{~m}$ ), and it appears to be the first valid description of the beluga. There was no type specimen collected. The name has rarely or never been used in the last 120 years (I could find no such instances since 1900), and Hershkovitz (1966) incorrectly credited the name (as B[alaena] albicans) to Müller (1776), instead giving priority for the beluga to Pallas' Delphinus leucas (see below), a practice that has been erroneously followed ever since. Tomilin (1957) correctly showed Cetus albicans to be the senior synonym, but did not explain why this name was not used as the valid name of the beluga, instead again using Delphinapterus leucas. Therefore, in order to maintain stability, Cetus albicans should be declared a nomen oblitum. A proposal to designate the name a nomen oblitum (and thereby to protect Delphinapterus leucas - see next paragraph) has been made (Jefferson, 2021). Variant spellings include abians. 


\section{Delphinus leucas Pallas, 1776}

The short description in a footnote in Pallas has traditionally been viewed as the valid type description for the beluga. Although there was no illustration in the original, in a later publication, Pallas (1811, plate on p. 273) provided a very accurate drawing of his species (reproduced in Pilleri and Arvy, 1981), which is without a doubt a beluga (see also Pallas, 1778). The type locality is the Ob River in northeastern Siberia, but no type specimen was collected (and no figure was provided in the original account). However, it has been discovered that the name is preceded by Cetus albicans, which is actually the senior synonym. Since the name leucas has been in nearly constant use for the beluga in the last century or more, this name should be conserved as a nomen protectum (Jefferson, 2021). Variant spellings include leucaster, as used by Gray (1821).

\section{D[elphinus] phocaena albus Kerr, 1792}

This is not a new species name (as it has sometimes erroneously been considered), but a subspecies name, and therefore is outside the scope of this review.

\section{Delphinapterus beluga Lacépède, 1804}

In this fairly long account by Lacépède, he described the beluga under this new name. The type locality was said to be the Arctic Sea and North Atlantic Ocean, especially Davis Strait. No type specimen was collected, and the name is a junior synonym of Delphinapterus leucas.

\section{Delphinus canadensis Desmarest, 1822}

In this short description of the beluga ("dauphin blanc"), Desmarest used the name Delphinus canadensis as a renaming. The type locality is the seas of Canada. The name is a junior synonym of Delphinapterus leucas.

\section{Delphinus (Delphinapterus?) kingii Gray, 1827}

Gray provided a short description of what he considered a new species, based on a specimen obtained on a survey of the "coast of New Holland" (though the specific type locality is uncertain). The type specimen, collected by Captain King on his return trip from surveying the Australian coast, is still in the British Museum (NHMUK 368a; Table 3), but the account does not contain any illustrations of it. Hershkovitz (1966) cast some doubt about the origin of the specimen, supposedly collected by Captain King. The name is a junior synonym of Delphinapterus leucas.

\section{Beluga borealis Lesson, 1828}

Lesson used this name in the table of contents for his book, listing p. 192. But on that page, although a be- luga is described (under the name Delphinus leucas), the borealis name does not appear. There is no description of identifying features, nor illustration of Beluga borealis anywhere in the volume. Therefore, according to ICZN rules, this name should be viewed as a nomen nudum.

\section{Beluga glacialis Lesson, 1838}

According to Hershkovitz (1966), a description of this species appears on p. 194 of Lesson (1828), but in fact, there is no text description of this species in this book. The name Beluga glacialis apparently first appears in Lesson (1838) on plate 3, fig. 2, to illustrate the external appearance of a white small cetacean without a dorsal fin. Although there appears to be no text description under this name, the above-mentioned plate clearly shows this species to be a beluga. With this indication, the name is available, and therefore it is a junior synonym of Delphinapterus leucas.

\section{Beluga catodon Gray, 1846}

The short account by Gray describes this species based upon a skull in the NHMUK (I did not locate the specimen when I visited in 2019), collected from Greenland. There are no figures, but the brief description is adequate to identify this as a beluga. The name is a junior synonym of Delphinapterus leucas.

\section{Beluga declivis Cope, 1865}

This species is based on a very short description, which focuses mostly on perceived differences in the skeleton (Cope, 1865a). The type is a skeleton apparently in the MCZ (not confirmed), from an unknown locality (possibly Greenland). The name is a junior synonym of Delphinapterus leucas.

\section{Beluga concreta Cope, 1865}

This species is based on a short description (Cope, 1865a), which focuses mostly on perceived differences in the skeleton from other belugas. There is a type specimen in the ANSP (No. 2598, skeleton; Koopman, 1976), from an unknown locality (possibly Greenland). The name is a junior synonym of Delphinapterus leucas.

\section{Beluga rhinodon Cope, 1865}

This species was first mentioned in the species description for Beluga concreta, which focuses mostly on perceived differences in the skeleton (Cope, 1865a). There is a type specimen in the ANSP (No. 3011, skeleton; Koopman, 1976), which apparently comes from Upernavik, Greenland. The name is a junior synonym of Delphinapterus leucas. 


\section{Beluga angustata Cope, 1866}

Cope provided a short description of this new species of Arctic whale, possibly from Greenland. No illustrations were presented. Cope included a small table, which compared Beluga angustata with Beluga catadon. The type specimen is apparently kept at the ANSP (No. 3010, skeleton; Koopman, 1976). It appears that this is a beluga, and the name is therefore regarded as a junior synonym of Delphinapterus leucas.

\section{Delphinapterus freimani Klumov, 1935}

Klumov's species is based on a type locality in the White Sea. He considered that there were skull differences at the species level from other known beluga species. His account does include an outline drawing comparing the three species discussed, but these do not show any species-level differences. There are some comparative measurements presented in Barabash (1937). This name is a junior synonym of Delphinapterus leucas.

\section{Delphinapterus dorofeevi Barabash and Klumov, 1935}

This beluga species was described in a moderate-length account, which did not include any figures showing the animal. The species was mainly distinguished by supposed differences in the skull. The type locality is in the Okhotsk Sea, but it is not known if a type specimen was deposited in any collection. The name is considered a junior synonym of Delphinapterus leucas.

\section{Genus Orcaella Gray, 1866 - Irrawaddy and snubfin dolphins}

\section{Orcaella brevirostris (Owen in Gray, 1866) - Irrawaddy dolphin}

\section{Phocaena (Orca) brevirostris Owen in Gray, 1866}

Owen's very detailed description was used by Gray to designate this species from the type locality "east coast of India, the harbour of Vizgapatam" (Gray, 1866a). The type description of the skull is thorough and includes an illustration. The holotype specimen (a skull, NHMUK 1865.4.20.1) is still in the British Museum, and was recently examined by Beasley et al. (2005) and me (Table 3). See Arnold and Heinsohn (1996) for nomenclatorial history and proper authorship. This is the senior synonym and valid name of the Irrawaddy dolphin.

\section{Orcaella fluminalis Anderson in Gray, 1871}

This species was described from the "River Irawady" in a brief description by Gray. The authority for this species has been controversial, often cited as Anderson (1871); however, Beasley et al. (2005) made a strong case for citing Anderson in Gray (1871). The type specimen, an articulated skeleton, was earlier in the Indian
Museum, Calcutta, in the late 1880s (Sclater, 1891). It was later moved to the British Museum (NHMUK $1454 \mathrm{~b}$ or 77.12 .10 .17$)$, though it was not found on a visit there in 2019 (the specimen may have been temporarily moved from the collection shelves). The name is a junior synonym of Orcaella brevirostris.

\section{Orcaella heinsohni Beasley et al., 2005 - Australian snubfin dolphin}

\section{Orcaella heinsohni Beasley et al., 2005}

The Australian snubfin dolphin was described in 2005, the type specimen being a skull (QM JM471 [JCU MM61]) in the Queensland Museum. The type specimen was taken in a shark net at Horseshoe Bay, Magnetic Island, Queensland, Australia, on 21 April 1972. The new species was described in detail (with measurements and photos) and compared in detailed fashion to Orcaella brevirostris, and many diagnostic characters were identified. The description includes molecular characters. There are no synonyms, and this is the valid name of the Australian snubfin dolphin.

\section{Genus Orcinus Fitzinger, 1860 - killer whales Orcinus orca (Linnaeus, 1758) - killer whale [Delphinus] orca Linnaeus, 1758}

Although Kinze (2018) cast some doubt on the identity of the original description by Linnaeus, arguing that the name Physeter microps was what Linnaeus was using when referring to the killer whale (this may stem from Fabricius' [1780] use of the name), stability seems to have prevailed in this case. Lacépède (1804) apparently considered Delphinus orca to be a killer whale. His description referred to illustrations in Rondelet (1554) and Gesner (1558), both of which show a robust cetacean with a large dorsal fin and flippers, short beak, and teeth in both jaws. It is not clearly recognizable, but seems to suggest the killer whale more than any other species. Virtually all marine mammal biologists over the last several centuries have considered Linnaeus' Delphinus orca to be the senior synonym of the killer whale. No type specimen was collected, but Linnaeus stated that the species had serrated teeth in both jaws, and was a small whale ("Balaena minor") from the "Oceano Europaeo." Schlegel's (1841a) use of Delphinus orca has been listed as a junior synonym of Grampus griseus G. Cuvier, 1812, but Linnaeus' description, although not at all clear, seems to better fit the killer whale. Therefore, and notwithstanding Kinze's expert opinion, I continue to follow tradition and precedent, and view Linnaeus' name [Delphinus] orca as the senior synonym and valid name of the killer whale. 


\section{Delphinus serra Borowski, 1781}

Borowski's description of the "saw-fisch" was a species described from Spitzbergen, Davis Strait, etc. However, no type specimen was collected; it was based on a description in Brisson (1756). No illustration was provided. The name is now considered to be a junior synonym of Orcinus orca.

\section{Physeter microps Fabricius, 1780}

Fabricius based this species name on killer whales from the Greenland seas. His description is rather detailed, though no illustration was given, and no type specimen was designated. This name is a junior synonym of Orcinus orca.

\section{D[elphinus] gladiator Bonnaterre, 1789}

Bonnaterre's description of "l'épée de mer" translates to "swordfish," an old name for killer whales. This species was based on travelers' accounts of killer whales in Spitzbergen, Davis Strait, and New England, especially that of Anderson (1746). No type specimen was collected, and the description is brief, with no illustration. The name is a junior synonym of Orcinus orca.

\section{Delphinus duhameli Lacépède, 1804}

The description of this species was based on an individual cetacean that was injured and spent a good deal of time around the mouth of the Loire River, France. No type specimen was collected, but the type description is detailed and unmistakably refers to the killer whale (Lacépède, 1804; Perrin ${ }^{1}$ ). The name is a junior synonym of Orcinus orca.

\section{Delphinus grampus Desmarest, 1817}

Desmarest (often incorrectly cited as Blainville or Blainville in Desmarest) based this species, the "épaulard" (an old name for killer whale), on descriptions of North Atlantic killer whales, primarily the "grampus" of Hunter (1787). No type specimen was designated, but the type locality was "les mers du Nord." The name is now considered a junior synonym of Orcinus orca, and also the senior homonym of Delphinus grampus Gray, 1846 (= Globicephala).

\section{Orca capensis Gray, 1846}

Gray described this species from the Cape of Good Hope, southern Africa. The type specimen (skull purchased from B. M. Viney, Museum of the Royal College of Surgeons No. 1139) is presumably in the NHMUK (No. 1856.4.10.1 or No. 1165b), but I could

\footnotetext{
${ }^{1}$ Perrin, W. F. 2006. Review of the nomenclature of killer whales. Southwest Fish. Sci. Cent. Admin. Rep. LJ-06-01, 10 p. [Available from Southwest Fisheries Science Center, 8901 La Jolla Shores Drive, La Jolla, CA, 92037.]
}

not locate it on a visit in 2019. The skull is well illustrated (Gray, 1846, plate 9), making it clear that this is a killer whale, but the reported diagnostic characters of capensis are not reliable. The name is therefore considered a junior synonym of Orcinus orca, and also the senior homonym of Orca capensis Van Beneden, 1873 (= Cephalorhynchus heavisidii).

\section{Delphinus victorini Grill, 1858}

This species was based on a specimen stranded at the Knysna River, South Africa, and its external appearance was well-depicted in a drawing by Victorini (and published in Grill, 1858), leaving no doubt that this was a killer whale. It is unclear if a type specimen was collected. The name is a junior synonym of Orcinus orca.

\section{Orca eschrichtii Reinhardt in Eschricht, 1866}

In 1866, J. Reinhardt (following Prof. Steenstrup) named this species in honor of Danish cetologist D. Eschricht, based on skulls and skeletons of 3-4 individuals stranded near Kollefjord, Stromo Island, Faroe Islands. The types are reported to be in the NHMD, Copenhagen, Denmark, but D. K. Johansson ${ }^{2}$ reported that there is only one type specimen (a skull missing the lower jaw and all teeth) in the current collection (ZMUC CN15x). Although the original Danish paper was published in 1863 (Eschricht, 1863), it did not contain the note by J. Reinhardt, in which he published the name Orca eschrichtii (the latter was added as a short note to the 1866 English translation, after Eschricht's death). See Kinze (2011) for history. The name is a junior synonym of Orcinus orca. Variant spellings include eschricthi.

\section{O[rca] schlegelii Lilljeborg, 1866}

This species, Lilljeborg's lesser killer or "whale dog," was based upon two killer whale skeletons in the Bergen Museum, which were collected from an 1860 stranding near Bergen, Norway. The description is largely copied from Schlegel (1841a). Measurements are presented in the text, and it is unknown if the types are still extant. Perrin ${ }^{1}$ speculated that the name may date from Lilljeborg (1861), but the name does not appear in that reference. The name is a junior synonym of Orcinus orca.

\section{Orca magellanica Burmeister, 1866}

The holotype specimen is a skull in the MACN-Ma. It was collected in 1866 at Rio de Christiano Muer-

\footnotetext{
${ }^{2}$ Johansson, D. K. 2020. Personal commun. Nat. Hist. Mus. Denmark, Øster Voldgade 5-7, 1350 Copenhagen, Denmark.
} 
to, south of Cabo Corrientes, Buenos Aires, Argentina $\left(38^{\circ} 50^{\prime} \mathrm{S}\right)$. The description is moderately detailed, and the illustration only includes the rostrum and nares regions of the dorsal part of the skull. The description includes comparisons to Orca capensis and Orca gladiator Van Beneden and Gervais, 1880. The name is a junior synonym of Orcinus orca. Variant spellings include magellanicus.

\section{Orca ater Cope in Scammon, 1869}

Cope described what he considered a new species of killer whale as occurring on the "northwest coast from Oregon to the Aleutian Islands" and based it on the animal shown in plate 17, fig. 2 of Scammon (1874). He thought that killer whales with shorter dorsal fins were a species distinct from those with taller dorsal fins (we now know the ones with tall dorsal fins are adult males). No specimen was collected, though his type description is from animals observed at sea in the Strait of Juan de Fuca, near Port Angeles, Washington. The name is a junior synonym of Orcinus orca. Variant spellings include atra.

\section{Orca rectipinna Cope in Scammon, 1869}

Cope described this species as occurring off the "coast of California" and based it on the animal shown in plate 17, fig. 1 of Scammon (1874). He believed that killer whales with shorter and taller dorsal fins were separate species (we now know that individuals with tall dorsal fins are adult males). Apparently no type specimen was collected. It is likely that this nominal species corresponds to either Bigg's killer whale (transient form) or the resident killer whale of the Pacific Northwest, though this is not confirmed. The name is a junior synonym of Orcinus orca. Variant spellings include rectispina.

\section{Orca stenorhyncha Gray, 1870}

Gray described this "North Sea" killer whale based on specimens collected from Weymouth and the "English coast." He distinguished it from Orca latirostris and Orca pacifica by supposed features of the skull that do not appear to be reliable. The syntypes (skull and complete skeleton) still exist in the NHMUK (1846.8.7.3 or $361 \mathrm{~b}$; and 1874.7 .6 .3 or $361 \mathrm{c}$; Table 3 ). The name is a junior synonym of Orcinus orca.

\section{Orca latirostris Gray, 1870}

Gray described this "North Sea" killer whale based on skulls collected from the coast of Essex, England, U.K. The type still exists in the NHMUK (361a; Table 3). Gray distinguished it from Orca stenorbyncha and Orca pacifica by features of the skull that do not ap- pear to be reliable. The name is a junior synonym of Orcinus orca.

\section{Orca pacifica Gray, 1870}

Gray described this "North Pacific" killer whale based on a skull collected by Captain Deville from an unknown locality in the North Pacific. The type specimen was originally in the Zoological Society of London's collection, but now exists in the NHMUK (No. 1165a; the previous number 1065a was an error). Gray distinguished this species from Orca stenorhyncha and Orca latirostris by features of the skull that do not appear to be taxonomically reliable. The name is a junior synonym of Orcinus orca.

\section{Orca africana Gray, 1871}

A cetacean skull from Algoa Bay, South Africa, and illustrated in Van Beneden and Gervais' (1880) atlas (plate 47, fig. 2) was used as the basis of this new species, presumably a "smaller" type of killer whale. The type description was very brief, and it is possible that this was just a young specimen. It is unknown if the type specimen still exists (it is not in the NHMUK). The name is a junior synonym of Orcinus orca.

\section{Orca tasmanica Gray, 1871}

Gray described another species of killer whale in a very brief account, with no illustration. The type locality was from Tasmania, Australia, and the very minimal description was based on a 32 -inch $(0.8 \mathrm{~m})$ long skull depicted in Van Beneden and Gervais' (1880) atlas (plate 47, fig. 1). It is not known if the type is still in existence. The name is a junior synonym of Orcinus orca.

\section{Orca minor Malm, 1871}

Malm described this new species of killer whale from the North Atlantic, based upon a skeleton collected at Warberg, Sweden. The holotype is reportedly in the Goteborg Museum, collected or donated on 17 July 1849. Malm also described several other specimens in his detailed account, which included measurements, and provided an illustration of a vertebra. The name is a junior synonym of Orcinus orca.

\section{Orca antarctica Fischer, 1876}

Although no type specimen was designated, there is a detailed description of this species in Fischer's (1876) account. The species is based upon a description and drawing by M. Dumoutier of killer whales observed at sea during the "Voyage au Pole Sud" on the ships Astrolabe and Zelee. No specimens were collected. From 
Dumoutier's notes: "We estimate that their length is 14 to 15 feet $(5 \mathrm{~m})$; the head, very short, is rounded forward into a quarter-circle; the dorsal fin very large, triangular, very acute, is planted in the middle of the length of the back; its height is 2 or 3 feet. The coloring of these cetaceans is remarkable. A large spot of a beautiful golden yellow, of almost trapezoidal shape, is seen on the neck behind and above the eye..." From this description, this nominal species could correspond with the type-B killer whale, but all killer whale ecotypes in Antarctica acquire diatoms and can end up with yellow eyepatches $\left(\operatorname{Pitman}^{3}\right)$. The name is a junior synonym of Orcinus orca.

\section{Orcinus nanus Mikhalev et al., 1981}

Mikhalev and co-authors described a new species of killer whale, a "dwarf" form, based upon animals killed in Russian whaling operations in the Amundsen Sea, Crozet Islands, and southwestern Atlantic. External measurements are given in the account, but there are no illustrations and no type specimens were designated. Mitchell (1985) considered this name to be a nomen nudum, but the description is adequate to determine that this is a junior synonym of Orcinus orca. It is possible that this nominal species corresponds to the type-C killer whale.

\section{Orcinus mörzer-bruynsus Heintzelman, 1981}

Mörzer Bruyns (1971) described the "Alula whale," based on several at-sea sightings in the Gulf of Aden of what might have been killer whales with anomalous color patterns (sepia brown, with star-shaped patches on the body). These animals were later designated with the name Orcinus mörzer-bruynsus by Heintzelman (1981), which would be amended to Orcinus moerzerbruynsus. It is unclear exactly what species this was, and therefore the name would have to be considered a nomen dubium. However, since there was no formal designation of a name-bearing type, and the name was not accompanied by a formal designation as a new species, it does not subscribe to ICZN rules, and therefore the name is not available.

\section{Orcinus glacialis Berzin and Vladimirov, 1982}

This "yellow" type killer whale of the high latitudes of the Indian Ocean sector of the Antarctic was described as a new species by Berzin and Vladimirov from a holotype (No. 4 in the TINRO Museum, Vladivostok); however, the type specimen has since been discarded after being damaged in a storm $\left(\right.$ Berzin $\left.^{4}\right)$. Perrin ${ }^{1}$ stated

\footnotetext{
${ }^{3}$ Pitman, R. L. 2019. Personal commun. Southwest Fish. Sci. Cent., Natl. Mar. Fish. Serv., 8901 La Jolla Shores Drive, La Jolla, CA 92037.

${ }^{4}$ Berzin, A. 2019. Personal commun. to R. L. Pitman, Southwest
}

that the tooth shown in a photo in the published type description may qualify as a type specimen if it still exists. Despite the fact that Mitchell (1985) considered this name to be a nomen nudum, I disagree, as the account contains a detailed description with identifying features. I consider the name to be a junior synonym of Orcinus orca. Berzin and Vladimirov described Orcinus glacialis as a smaller, fish-eating killer whale, often covered with yellowish diatoms, that lived in the pack ice. They cited differences in body proportions (e.g., smaller flukes) and skull proportions that strongly suggest Orcinus glacialis as the type-C killer whale.

\section{Genus Globicephala Lesson, 1828 - pilot whales Globicephala melas (Traill, 1809) - long-finned pilot whale}

\section{Delphinus melas Traill, 1809}

Based on a mass stranding of 92 pilot whales at Scapay Bay, Pomona, in the Orkney Islands, Traill described this new species in 1809. The account provides details on the external appearance (including a good illustration of body shape and color pattern) and behavior of the animals, which were said to abound around the Orkney and Shetland Isles. However, there is no description of the skull or skeleton, and no type specimen is mentioned. A lectotype has been designated in the NHMUK (No. 44.12.3.2; Hershkovitz, 1966), apparently from among the 92 specimens that were mass stranded. This name is the senior synonym and valid name of the long-finned pilot whale, and also the senior homonym of Delphinus melas Schlegel, 1841b (= Neophocaena asiaeorientalis). Although the gender emendation melaena was used for many years (after Thomas, 1898), the original spelling melas is in current use, following Jones et al. (1986). Variant spellings include melaena and mela.

\section{Delphinus globiceps G. Cuvier, 1812}

Cuvier based his description of Delphinus globiceps (the dolphin of St.-Brieux) on characteristics of pilot whales from European waters. The description is rather brief, but there is a very accurate illustration of the external appearance of a long-finned pilot whale (middle two illustrations in his plate 1). It is unclear if any type specimen was collected or deposited. This name is a junior synonym of Globicephala melas.

\section{Delphinus deductor Scoresby, 1820}

Scoresby appears to have used this name as a replacement name for the European pilot whale already known

Fish. Sci. Cent., Natl. Mar. Fish. Serv., 8901 La Jolla Shores Drive, La Jolla, CA 92037. 
as Delphinus melas. Scoresby described the general appearance and ecology of this species, but provided little detail on the skeleton. This name is now considered to be a junior synonym of Globicephala melas.

\section{Delphinus grinda Lyngbye, 1826}

Lyngbye described a species of small whale taken in the "grind," the traditional pilot whale drive fishery of the Faroe Islands. He included a detailed description of the animals in this account, but with no illustrations. However, paintings of the animals have been discovered in his unpublished notebooks (Lyngbye $\left.^{5}\right)$, which clearly show that these are long-finned pilot whales. No type specimens appear to have been collected or deposited. This name is a junior synonym of Globicephala melas.

\section{Delphinus intermedius Harlan, 1827}

The type specimen was harpooned at Salem, Massachusetts, and the holotype is supposedly still preserved at the ANSP (this needs to be checked, and the specimen is not listed in Koopman, 1976). Although sometimes considered a nomen dubium, the detailed description and illustration provided by Harlan leave little doubt that this was a long-finned pilot whale, and I place the species firmly in the synonymy of Globicephala melas. This name is also the senior homonym of Delphinus intermedius Gray, 1827 (= Feresa attenuata).

\section{Phocaena globiceps Lesson, 1827}

Lesson described this species from an unknown locality in the Atlantic Ocean, presumably near Europe. A type specimen was apparently collected, but it is not known if it still exists (it could not be located in the NHMUK in 2019). The general description could apply to either species of pilot whale, but Lesson's comments on the number of teeth: "there are 9 to 13 teeth on each side and up and down" suggest that he was describing a long-finned pilot whale. The name is therefore provisionally considered to be a junior synonym of Globicephala melas.

\section{Phocaena edwardii Smith, 1834}

The short account by Smith mainly describes the external appearance from animals observed near the Cape of Good Hope, South Africa. There are no illustrations, and the description could refer to one of several species of "blackfish." There is apparent-

\footnotetext{
${ }^{5}$ Lyngbye, H. C. Unpubl. notebooks. [Available from http://faeroensis. blogspot.com/2017/07/da-hc-lyngbye-var-i-grind-i-hvalba-1817. html.]
}

ly a type specimen in the Museum of Natural History, Bordeaux; it needs to be examined to confirm identity. This name is tentatively considered a junior synonym of Globicephala melas, and the senior synonym of the subspecies Globicephala melas edwardii (SMM, 2020). Variant spellings include edwardi and edwardsii.

\section{Globicephalus conductor Rapp, 1837}

Rapp used this species name as a new name for the "globicephale conducteur" of Lesson (1828, p. 278). It is unknown if a type specimen was collected. The description is rather brief, with no illustrations. This name is a junior synonym of Globicephala melas.

\section{Globicephalus affinis Gray, 1846}

Gray's typically-short description says that this may be the young of Globicephalus svineval; nonetheless he gave it a new name. The type specimen was said to have been in the Museum of the Royal College of Surgeons (No. 2999), but its current whereabouts is not known. Gray (1866a) caused some confusion when he listed the same specimen (Museum of College of Surgeons No. 1138) under two different genera and three different species: Globicephalus affinis, Globicephalus svineval, and Grampus sp. This name is regarded as a junior synonym of Globicephalas melas.

\section{Globicephalus svineval Gray, 1846}

Gray used this species name as a new name for the "Cachelot svinewal" of Lacépède (1804). Gray's brief account described several specimens of this new species, supposedly from the coast of North America, presumably the east coast. The type or types were in the Museum of the Royal College of Surgeons, possibly later transferred to the NHMUK (though I could not find them there in 2019). This name is a junior synonym of Globicephala melas.

\section{Delphinus grampus Gray, 1846}

Gray used this name in the synonymy of Globicephalus svineval. However, the name is a junior homonym of Delphinus grampus Desmarest, 1817 (=Orcinus orca), and therefore cannot be a valid name.

\section{Globiocephalus incrassatus Gray, 1861}

Gray's detailed description and multiple illustrations of the skull of this nominal species place it firmly in the genus Globicephala, though the skull is somewhat damaged and worn, making it challenging to tell if it is a long- or short-finned pilot whale (Fig. 4). However, 
based on the position of the maxillae and premaxillae and the length/ width ratio of the rostrum, it is confirmed to be a specimen of Globicephala melas (Fig. 4). The stated habitat of the species is the "British seas" and the tag lists Bridgeport. The type specimen is still at the NHMUK (No. 1853.1.5.1; Table 3). This name is a junior synonym of Globicephala melas.

\section{Globicephalus chiliensis Philippi, 1895}

Philippi described this species, based on a specimen from Chile in the MNHNS in Santiago. The very detailed and accurate skull illustrations in the accompanying plate (plate 1 , figs. 3,4 ) show that this specimen is a long-finned pilot whale. The name is now considered to be a junior synonym of Globicephala melas.

\section{Delphinus melaena Thomas, 1898}

This was an unjustified emendation of the original species name Delphinus melas. It is listed here, since it is different enough from the original name to appear as if it is a separate species name. In fact, this unjustified spelling was used extensively in the latter part of the twentieth century. However, in recent years the valid name of the short-finned pilot whale has reverted back to Globicephala melas, following Jones et al. (1986).

\section{Globicephala leucosagmaphora Rayner, 1939}

Rayner's short description of this new species of pilot whale is based on a specimen harpooned 40 miles (64 $\mathrm{km})$ SSW of the Cape of Good Hope. It was thought to be a unique species due to perceived coloration pattern differences. The account does not include any illustrations, but does mention that a skeleton was being prepared. The type specimen (skull and skeleton) is in the NHMUK (No. 1992.78; Table 3); a note in the account says that a more detailed description will be forthcoming, but I am unaware of such ever being published. This name is a junior synonym of Globicephala melas. 


\section{Globicephalus sieboldii Gray, 1846}

Gray named this species, based on syntype specimens collected in 1827 from Nagasaki, Japan. The lectotype specimen (skeleton) is still in the collection of the RMNH (No. 21648). Earlier authors who described it (e.g., Schlegel, 1844) did not regard the specimen as different enough from European pilot whales to justify a new species, but Gray's tendency toward splitting resulted in this nominal species. The name is now considered to be a junior synonym of Globicephala macrorhynchus (see van Bree, 1971a).

\section{Delphinus fuscus Reichenbach, 1846}

Reichenbach's very short account introduces this name (credited to Jardine), but provides little detail and no illustrations. Apparently, no type specimen was collected. This name was supposedly based on "blackfish" described by Lesson (1826), and is thus tentatively considered a junior synonym of Globicephala macrorbynchus, according to van Bree (1971a).

\section{Globicephalus indicus Blyth, 1852}

Blyth provided a short description of this species. It was based on syntype specimens killed "in the Hugly" near Serampore, Bay of Bengal, India. A stuffed specimen was created and deposited in the Indian Museum, Calcutta (it is unknown if it still exists). This name is a junior synonym of Globicephala macrorhynchus.

\section{Globicephalus scammonii Cope in Scammon, 1869}

In a rather short description (including no illustrations), Cope described this species of pilot whale from the eastern Pacific $(16 \mathrm{~km}$ off the coast of Baja California, Mexico, at $\left.31^{\circ} \mathrm{N}\right)$. Scammon (1874) in his classic book, The Marine Mammals of the Northwestern Coast of North America, provided much more detail on the anatomy (including illustrations of external appearance) and habits of this species. A lectotype specimen (skull, USNM 238167, earlier cataloged as USNM 9074) was designated by True (1889), and is housed in the USNM (see Fisher and Ludwig, 2016, for history). The name is now considered to be a junior synonym of Globicephala macrorbynchus. Variant spellings include scamonii and scammoni.

\section{Globiocephalus propinquus Malm, 1871}

Malm provided a long description of this new species of pilot whale, complete with various measurements and detailed anatomical description. It is based on a fetus preserved in alcohol, apparently from somewhere in the Atlantic Ocean, and the type specimen is in the Goteborg Museum. The only illustration provided shows the bones of the pectoral fin. The name is now considered to be a junior synonym of Globicephala macrorbynchus.

\section{Globiocephalus guadaloupensis Gray, 1871}

Gray named this species, apparently based on a specimen stranded on the coast of Guadaloupe (French Antilles) and residing in the MNHN (No. A.3215). There is no description of identifying features, and no illustration; however, Robineau (1990) later provided a brief description. Although the name has been considered to be a junior synonym of Globicephala macrorhynchus (van Bree, 1971a), the lack of description indicates that this name should actually be considered a nomen nudum.

\section{Globicephalus sibo Gray, 1871}

Gray recognized this new species as a type of pilot whale from Japan (and called "Sibo golo" by the Japanese). It supposedly was distinguished by being "purple, with a white spot behind the dorsal fin," the latter of which probably refers to the post-dorsal fin saddle. Apparently, no type specimen was collected, and there is not an adequate description, so this name might be considered by some to be a nomen nudum. However, based on the collection locality, it is here tentatively viewed as a junior synonym of Globicephala macrorbynchus.

\section{Globicephalus brachypterus Cope, 1876}

Cope described this species based on syntype specimens from Delaware Bay, which are supposedly stored in the ANSP (this needs to be checked, and the specimens are not listed in Koopman, 1976). The description is quite detailed, and there are very accurate illustrations of several views of the skull, which show clearly that this is a short-finned pilot whale. The name is considered to be a junior synonym of Globicephala macrorhynchus. Variant spellings include brachyptera and brachycephala.

\section{Genus Pseudorca Reinhardt, 1862 - false killer whales}

\section{Pseudorca crassidens (Owen, 1846) - false killer whale}

\section{Delphinus dalippus Rafinesque Schmaltz, 1814}

This long-forgotten name was recently shown by Woodman et al. (2020) to be the senior synonym for the false killer whale. The name actually antedates Pseudorca crassidens, the valid name, by 32 years. However, Delphinus dalippus has not been used for the false killer whale, apparently due to the relative obscurity of the indication (a short description and illustration) that it was based on. 
In order to maintain stability, Delphinus dalippus should be designated a nomen oblitum, thereby protecting Pseudorca crassidens as the valid name.

\section{Phocaena crassidens Owen, 1846}

Owen described this species in his book on fossil mammals and birds from the U.K., from a subfossil specimen collected in 1843 from "Lincolnshire Fens, near Stamford, England." Owen was not sure if the species was extinct, but he suspected it might still be extant (see also Pilleri and Arvy, 1981). His description contains measurements and illustrations of the skull and cervical vertebrae. The type specimen was deposited in the Museum of Stamford Institute, later apparently moved to the Royal College of Surgeons and then the Cambridge University Museum, but apparently was eventually lost. The species, of course, is still extant, and this is now the valid name for the false killer whale (see Reinhardt, 1866).

\section{Orca meridionalis Flower, 1864}

Flower, originally thinking this was a type of killer whale, provided a detailed description of this species from two specimens (skulls) collected from Tasmania. $\mathrm{He}$ included measurements and illustrations of the skulls, which were in the Royal College of Surgeons (No. 2986), London, and now reside in the NHMUK (No. 1946.8.9.3; Table 3). He later (Flower, 1865) moved the species to the genus Pseudorca, allying it with the false killer whale. The name is considered a junior synonym of Pseudorca crassidens.

\section{Orca destructor Cope, 1866}

Cope published a short description of the skull of this species. The type locality of this species was from the southern Pacific, off Paita, Peru. The holotype composed of a rostrum and mandible is in the USNM (No. 3679), but I have not examined it. The name is considered a junior synonym of Pseudorca crassidens.

\section{Globicephalus grayi Burmeister, 1868}

Burmeister first described this species in a short paper published in 1868, in which he characterized and illustrated the skull from a specimen found on shore at Buenos Aires, Argentina. In a more detailed account the following year, Burmeister (1869) re-described the species, including a sighting at sea from a locality reportedly in the mid-Atlantic off Brazil $\left(8^{\circ} \mathrm{S}, 22.5^{\circ} \mathrm{W}\right)$. Burmeister's (1869) plate 1 shows an illustration of the school at sea, an outline of the body, and several views of the skull. The illustrations of the external appearance suggest pilot whales (Globicephala sp.), but the skull illustrations clearly indicate that this was a false killer whale. A group of five cetaceans sighted were included in this original description, but Burmeister (1872) later reported that those cetaceans observed atsea were not the ones he was describing as Globicephala grayi, but were indeed pilot whales. He also stated that his Globicephala grayi was in fact a representative of the genus Pseudorca. The type specimen is thought to still exist in the MACN-Ma, and the name is considered a junior synonym of Pseudorca crassidens.

\section{Pseudorca? mediterranea Giglioli, 1882}

The species was described from two skulls collected in the Mediterranean Sea (unknown location in Italy/Sicily). Giglioli provided a description with some details of the skull and comparisons to other known species. The type was deposited in the Florence Museum, though it is not known if it still exists to this day. The name is considered a junior synonym of Pseudorca crassidens.

\section{Genus Feresa Gray, 1870 - pygmy killer whales}

Feresa attenuata Gray, 1874 - pygmy killer whale

\section{Delphinus intermedius Gray, 1827}

This name is a junior homonym of Delphinus intermedius Harlan, 1827 (= Globicephala melas) (Hershkovitz, 1966), and therefore cannot be a valid name. Gray's name is based on a specimen from an unknown locality, which is still in the British Museum (NHMUK 362a; Table 3). The type description is not very detailed and no illustrations are presented. Variant spellings include intermedia.

\section{Feresa attenuata Gray, 1874}

This species was described from a specimen in the NHMUK (skull still held as No. 1874.11.25.1; Table 3 ), collected from an unknown location in the "South Seas." The original description is very short on details and contains no illustrations. A follow-up paper was published the next year (Gray, 1875), and though not much more detailed, was accompanied by several illustrations of the skull and earbones. Because the older name, Delphinus intermedius (a junior homonym), was preoccupied, Feresa attenuata is the valid name for the pygmy killer whale.

\section{Feresa occulta Jones and Packard, 1956}

Jones and Packard proposed this name as a replacement name for Delphinus intermedius (this name was found to be preoccupied - see above), which they considered to be a separate species from Feresa attenuata. However, there is currently considered to be only a single species of pygmy killer whale, and thus Feresa occulta becomes a junior synonym of Feresa attenuata. 


\section{Genus Peponocephala Nishiwaki and Norris, 1966 - melon-headed whales}

\section{Peponocephala electra (Gray, 1846) - melon- headed whale}

\section{Lagenorhynchus electra Gray, 1846}

Gray provided a short description of this species from a skull in the British Museum (NHMUK 1844.19.5.3; Table 3), which came from an unknown locality. The accompanying illustration of the type specimen (plate 13) clearly shows the skull of a melon-headed whale, and this name is thus the senior synonym and valid name of Peponocephala electra.

\section{Lagenorhynchus asia Gray, 1846}

Gray described this species from a skull, which is still in the British Museum (NHMUK 358a; Table 3), and which came from an unknown locality. Gray's (1846) description was brief, but his illustration of the type (plate 14) shows the skull of what is without a doubt a melon-headed whale, and this name is thus a junior synonym of Peponocephala electra.

\section{Phocoena pectoralis Peale, 1849}

Peale described this species from a specimen harpooned at the bow of the U.S.S. Peacock (on the U.S. Exploring Expedition) at $27^{\circ} 16^{\prime} \mathrm{S}, 75^{\circ} 30^{\prime} \mathrm{W}$ (note that Peale's volume was later withdrawn, due to a belief that it contained too many taxonomic errors; see p. 343 in Philbrick, 2003). In the later re-issued version of this volume (Cassin, 1858), virtually the same description appears under the name Delphinus pectoralis. The holotype specimen is a mandible in the USNM (No. 4108). The description and illustrations of external appearance (which appeared in Cassin, 1858, plate 5 , fig. 2) definitely show a melon-headed whale, and this name is thus a junior synonym of Peponocephala electra.

\section{Delphinus (Lagenorhynchus) fusiformis Owen, 1866}

This species was described from a specimen collected off Waltair, India, by Walter Elliot. The type specimen is in the British Museum (NHMUK 1866.2.5.1; Table $3)$. Although Owen's description and illustration of the external form of the body show a beaked dolphin (possibly Tursiops or Delphinus), the description and illustrations of the skull (Owen, 1866, plate 7) identify this as a melon-headed whale, and this name therefore is a junior synonym of Peponocephala electra. It is possible that the drawings of the external body (which were prepared by an Indian artist under Walter Elliot's supervision) were mixed up before being received by Owen at the British Museum.

\section{Electra obtusa Gray, 1868}

This is a renaming of Lagenorbynchus electra. Gray's (1868a) description is quite brief, with little new information and no illustrations provided, though description of the type can be found in Gray (1846) under Lagenorbynchus electra. This name is a junior synonym of Peponocephala electra.

\section{Genus Grampus Gray, 1828 - grampus \\ Grampus griseus (G. Cuvier, 1812) - Risso's dolphin}

\section{Delphinus griseus G. Cuvier, 1812}

Cuvier provided a very short description and a rather crude illustration of this new species of dolphin from Brest, France, which served as the type description for Risso's dolphin. There is a type specimen (skull and postcranial skeleton) in the MNHN (JAC: 1944-307, 1945-4; CAG: B II/156). The external illustration in Cuvier's account is not clearly identifiable to species, but this is generally considered the senior synonym and valid name of Risso's dolphin. Robineau (1990) published an illustration of the type skull, clearly showing what is known today as Grampus griseus.

\section{[Delphinus] aires G. Cuvier, 1812}

In another brief description, Cuvier introduced this new species, though it is never described using this name in the text of the paper (he only calls it "l'aries marinus," which Hershkovitz, 1966, interpreted as Delphinus aires). Cuvier did, however, provide an illustration of the species (labeling it "Delphinus aires?" in the bottom illustration of his plate 1); this shows an animal that can be clearly identified as a Risso's dolphin (the only major flaw being the flippers placed too far back on the body). No type specimen was identified. This name is regarded as a junior synonym of Grampus griseus.

\section{Delphinus rissoanus Desmarest, 1822}

Desmarest called this "dauphin de Risso" and he was clearly describing what we know today as Risso's dolphin. Although no type specimen was specifically designated (and there is no illustration), he identifies this species as found in the Mediterranean, in the vicinity of Nice. This is a junior synonym of Grampus griseus. Variant spellings include rissonus.

\section{D[elphinus] risso Risso, 1826}

This nominal species was based on a specimen from Nice, France, collected some time before 1811 by Risso (probably the same specimen used by Cuvier, 1812). 
There is a short description of the species, which was said to be about $3 \mathrm{~m}$ in length, and the color plate leaves no doubt about the species involved. Risso credited the name to Cuvier, though Cuvier's published names for Risso's dolphins were griseus and aries. No preserved type specimen is known. The name is a junior synonym of Grampus griseus. Variant spellings include rissoi.

\section{Globicephalus rissii Hamilton, 1837}

Hamilton provided a brief description and beautiful color plate of the external appearance of this species, and he obviously based this on Risso's species (see D[elphinus] risso), modifying the name. The plate makes clear the species involved is a Risso's dolphin. The name is considered a junior synonym of Grampus griseus. Variant spellings include rissonus.

\section{Grampus cuvieri Gray, 1846}

Gray introduced this species name as a replacement name for Cuvier's Delphinus griseus, largely repeating information on its characters from previous work by the Cuvier brothers (Georges and Frederic) and d'Orbigny. The name is now considered to be a junior synonym of Grampus griseus.

\section{Grampus sakamata Gray, 1846}

This is a replacement provided by Gray for a species originally mentioned by Schlegel (1844) from Japan (Gray calls it Sakamata kuzira, but in fact Schlegel never formally named it in the short footnote where he introduced it). There is a holotype specimen (donated by the Japanese government) in the MNHN (No. JAC: $1877-$ 276), and Robineau (1990) presented measurements of the skull and history of the specimen. He also stated that the skull figured by Gervais in the Van Beneden and Gervais atlas (1880) (plate LXIV, fig. 5, p. 568) is the type of Grampus sakamata. The name Grampus sakamata is now considered to be a junior synonym of Grampus griseus. Variant spellings include sakata.

\section{Grampus richardsoni Gray, 1850}

Gray provided a very short description of a specimen in the NHMUK (No. 1626a; previously in the Haslar Hospital Museum) from an unknown locality, and it represents the type description for this species. The type consists only of the lower jaw. In 1866, Gray provided a more detailed description, with some measurements, and stated that the species came from the Cape of Good Hope. The name is a junior synonym of Grampus griseus.

\section{Grampus stearnsii Dall, 1873}

Dall proposed this new species of Grampus, from specimens observed off the coast of California, near Monterey (and described as the "whiteheaded or mottled grampus" by Scammon, 1874). Although no formal holotype specimen was designated by Dall (1873), a description of the jaws of a specimen collected by Scammon are provided, and a more detailed description with measurements is provided in Dall (1874). A lectotype was designated by F. W. True (USNM 13021), and is currently in the Smithsonian's USNM (see Fisher and Ludwig, 2016, for details). The name is a junior synonym of Grampus griseus.

\section{Grampus sowerbianus Fischer, 1881}

Fischer provisonally described this species of Grampus, which he thought might be new, based on a skull preserved in the Bordeaux Museum, France, and whose origin was unknown. His short description provides skull measurements, but no illustrations. The species is not considered valid, and the name is a junior synonym of Grampus griseus.

\section{Grampidelphis kuzira Iredale and Troughton, 1933}

This name was proposed as a replacement name for Grampus sakamata (Iredale and Troughton stated that it was the name of Van Beneden and Gervais, 1880, and not of Gray, 1846). The account was rather detailed, but did not provide any illustrations. The name is now considered to be a junior synonym of Grampus griseus.

\section{Grampidelphis exilis Iredale and Troughton, 1933}

The authors provided a detailed description, measurements, and several skull photos of the types for this new nominal species of Grampus. These types were deposited in the Australian Museum (including a holotype AM S.1776, cast and complete skeleton from Ocean Beach, Sydney, Australia; and "paratype" AM S.1832, skull from Dee Why Beach, north of Manly, Australia; Parnaby et al., 2017). The name is now considered to be a junior synonym of Grampus griseus.

\section{Genus Sotalia Gray, 1866 - estuarine dolphins \\ Sotalia fluviatilis (Gervais and Deville in Gervais, 1853) - tucuxi}

\section{Delphinus fluviatilis Gervais and Deville in Gervais, 1853}

Gervais and Deville in Gervais (1853) introduced this species name in a short footnote, with very little in the way of description and no figures. Gervais (1855) gave a much more detailed description, providing the diagnostic features and also a painting of the body 
showing external features. There has been some controversy as to the authorship of the type description, which is discussed in van Bree (1974a). The holotype specimen consists of a rostrum and mandibles held at the MNHN (JAC: 1880-550), collected from near Pebas, Marañon River, Peru (upper Amazon basin). Robineau (1990) provided a photo of the holotype, as well as some measurements. This name might be considered a nomen nudum by some (as it has by Cabrera, 1957), and some have regarded Gervais as the sole author of the description. However, I have followed tradition by crediting the name, which is the senior synonym and valid name for the tucuxi, to Gervais and Deville in Gervais (1853).

\section{Delphinus pallidus Gervais, 1855}

This species was based on a specimen apparently collected from Loreto or Nauta, in the Peruvian Amazon (though a label on the skull indicates Fonte Boa, Brazil, according to Robineau, 1990). In the original reference, a detailed description was provided with some measurements and illustrations of the whole body. The type specimen still exists in the MNHN (skeleton: JAC: 1880-549; stuffed skin: CGZ No. 29), and details and measurements were provided by Robineau (1990). Apparently, this was just a color variant of Delphinus fluviatilis, and the name is now considered to be in the synonymy of Sotalia fluviatilis. Variant spellings include pallida.

\section{Steno tucuxi Gray, 1856}

This species was based on male and female skulls in the NHMUK (No. 1189a and 1189b, respectively; one of these also has the number BMNH 1856.8.2.2; Table 3), collected by H. W. Bates in the Amazon River of Brazil, apparently near Santarem. The type description is short, with some discussion and measurements of the skull, but no figures or illustrations. The name is now considered a synonym of Sotalia fluviatilis. Variant spellings include tuchuschi and tucaxi.

\section{Sotalia guianensis (P. J. Van Beneden, 1864) - Guiana dolphin}

\section{Delphinus guianensis P. J. Van Beneden, 1864}

The two syntypes include a skull and complete skeleton (Nos. 1516, 2349) held at the Musee Royal d'Histoire Naturelle de Belgique, Brussels, Belgium, previously held at the Stuttgart Museum, Germany. They were collected from the mouth of the Maroni River (or Marowijne River), near the border between French Guiana and Surinam. The type description is quite detailed, and it includes an illustration of the complete skeleton. This is the senior synonym and valid name for the recently resurrected Guiana dolphin (or "costero"). Variant spellings include guyanensis.

\section{Sotalia brasiliensis E. Van Beneden, 1875}

Edouard (not the more well-known P. J.) Van Beneden described this species from a specimen collected at the Bay of Rio de Janeiro (Baia de Guanabara), Brazil. He provided a very detailed description of the animal, including measurements, and illustrations of the external appearance, skull, and postcranial skeleton. The holotype specimen (skin and complete skeleton) is thought to reside in the Louvain Museum, Brussels, Belgium. This name is considered to be a synonym of Sotalia guianensis. Variant spellings include braziliensis.

\section{Genus Steno Gray, 1846 - rough-toothed dolphins}

\section{Steno bredanensis (Lesson, 1828) - rough- toothed dolphin}

\section{Delphinus bredanensis Lesson, 1828}

This species of dolphin was described from a specimen collected from the River Scheldt (Belgium). Lesson had drawings available to him that depicted this dolphin and its skull, preserved in the Ghent University $\mathrm{Mu}-$ seum, which were also published by the collector, J. G. S. Van Breda (1829). The drawings have apparently not been recently examined and may have been lost. Bekker et al. (2016) recently rediscovered the skull that the species description was based on (Ghent University Museum, No. MDV50426). Several undocumented skulls in Paris were considered by Smeenk (2018) to be syntypes (or more accurately, paratypes). This name is the senior synonym of the rough-toothed dolphin. The author of this species is sometimes incorrectly cited as G. Cuvier or G. Cuvier in Lesson. See Smeenk (2018) for a detailed history of this name, its history, and related nomenclature. Variant spellings include bredansis and bredaensis.

\section{Delphinus chamissonis Wiegmann, 1840}

Wiegmann published a plate (plate 359) depicting this species, which represents the first use of this species name. However, since there was no description of distinctive features (and no reference to such), nothing was known of its external appearance. To some, the name might not appear to be available, but under ICZN Article 12.2.7, the name is indeed available, and is therefore a junior synonym of Steno bredanensis. 


\section{Delphinus planiceps Schlegel, 1841}

This name was applied to the rough-toothed dolphin by Schegel (1841b), who erroneously attributed the name to Van Breda (1829). It is essentially a renaming of Delphinus bredanensis. Schlegel copied the name from an undocumented specimen in the RMNH (see Smeenk, 2018, for detailed history). The name is considered an objective junior synonym of Steno bredanensis.

\section{Delphinus reinwardtii Schlegel, 1841}

This species was described from two syntype specimens in the RMNH (skull: No. 31179; incomplete skull: No. 31180), which were collected by C. G. C. Reinwardt from the island of Java, Indonesia. The illustrations of the skull and description in Schlegel (1841b) clearly indicate that this is a rough-toothed dolphin, and the name is considered a junior synonym of Steno bredanensis.

\section{Delphinus compressus Gray, 1843}

Gray (1843a) introduced this name for a skull in the NHMUK (No. 346a), but there was no description or illustration of identifying characters. In fact, the only thing said about this species was that there was a "skull" in the collection (I confirmed this in 2019). Therefore, the name is considered a nomen nudum, and is not available. The type locality is unknown.

\section{Delphinus chamissonis Wagner, 1847}

The authorship of Wagner's species Delphinus chamissonis is sometimes cited as Wiegmann, 1840; this is likely because Wiegmann prepared the plate for this species some time earlier than the time of Wagner's 1847 publication. In Wagner's book, he provides a brief description, which together with the relevant illustration (plate 359) indicates that this is a roughtoothed dolphin. The name is a junior synonym of Steno bredanensis.

\section{Steno compressus Gray, 1850}

Gray made this name available again (see above under Delphinus compressus) by finally describing the type skull, and stating that it was the specimen figured in Gray (1846, plate 27). The type specimen (No. 346a; Table 3) is still in the collection of the NHMUK. The information presented in Gray (1850) and the plate in Gray (1846) make it clear that this is a rough-toothed dolphin, and the name is therefore a junior synonym of Steno bredanensis.

\section{Delphinus (Steno) perspicillatus Peters, 1877}

This species was based on a specimen (complete skeleton) in the Berlin Museum (ZMB No. 5097) from the
Atlantic Ocean, harpooned at the reported position of $32^{\circ} 29^{\prime} \mathrm{S}, 2^{\circ} 1^{\prime} \mathrm{W}$. While the illustration of the external appearance of the harpooned specimen provided by Peters does not look at all like a rough-toothed dolphin (it shows a beak distinctly separated from the forehead), the detailed illustrations of the skull clearly show several unmistakeable diagnostic features of Steno bredanensis. This dilemma was recognized and discussed by True (1889), who clearly saw that something was not right, but did not feel he had the information to resolve it. It now seems likely that there was some mix-up, and the illustration of the external appearance (Peters, 1877 , plate 2) was from a specimen of the common dolphin (Delphinus delphis), which was the other species of dolphin caught on the same voyage (see Fraser, 1966). The skull (plate 3), which is archived and available for study in the Berlin Museum, is thus taken as the correct type specimen, and so the name is considered to be a junior synonym of Steno bredanensis (see West et al., 2011).

\section{Genus Sousa Gray, 1866 - humpback dolphins Sousa chinensis (Osbeck, 1765) - Indo-Pacific humpback dolphin}

\section{Delphinus chinensis Osbeck, 1765}

Pehr Osbeck (a student of Linnaeus) based this species on a sighting of live animals observed in the Canton (Pearl) River, Guangdong Province, China, in 1751. The stated white color of the dolphins and their location leave little doubt that this is what today we know as the Indo-Pacific humpback dolphin (locally called "Chinese white dolphin" in southern China). No type specimen was designated, as the original publication date of Osbeck's description was 1757 , the year before the starting point of modern taxonomic nomenclature (1 January 1758; Linnaeus, 1758). Therefore, the translation of Osbeck's description into German (Osbeck, 1765) is used as the official description of the species (see Hershkovitz, 1963; Pilleri, 1979). The description was later translated into English (Osbeck, 1771). The detailed description of a specimen by Flower (1870) was viewed as a "substitute" for an official type specimen, but unfortunately a bombing raid in World War II resulted in the destruction of that skeletal material (Pilleri, 1979). Porter (2002) designated a neotype (skull and skeleton) from Hong Kong and deposited it in the NHMUK (ZD 1999.360; Fig. 5). Porter's $(1998,2002)$ descriptions of the neotype specimen contain a number of serious errors, it has thus been suggested that Porter's measurements not be used for comparative purposes (see Jefferson and Karczmarski, 2001; Jefferson and Rosenbaum, 2014). I examined the specimen in 2019, and the skull measurements I took 


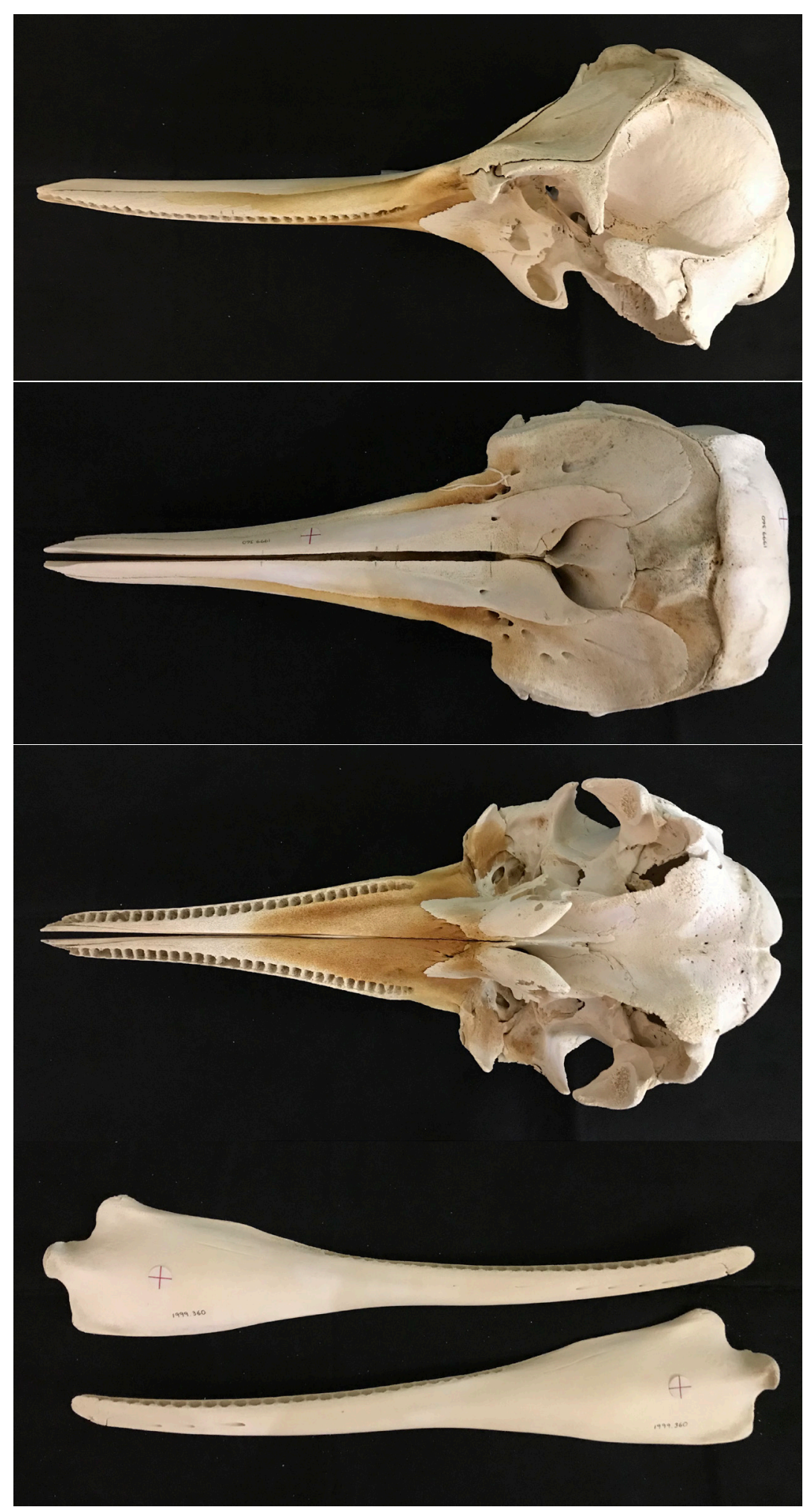

Figure 5

The neotype specimen of Delphinus chinensis Osbeck, 1765 (NHMUK ZD 1999.360). 
are presented in Table 3 . The correct vertebral counts are $\mathrm{C} 7$, Th12, $\mathrm{L}+\mathrm{Ca} 30$ (with 2-3 missing at the end), for a total count of 51-52. Sousa chinensis is the senior synonym of the Indo-Pacific humpback dolphin, as redescribed in Jefferson and Rosenbaum (2014). Variant spellings include sinensis.

\section{Sotalia borneensis Lydekker, 1901}

Lydekker described this species from the skin and skeleton of a dolphin collected at "Sipang," near the mouth of the Sarawak River, in what is present-day Malaysian Borneo. The type specimen is in the Natural History Museum, London (skull and skeleton: NHMUK 1901.2.16.1; Table 3, Fig. 6); it was measured for Jefferson and Van Waerebeek (2004). Lydekker's type description is fairly detailed and includes illustrations of the skull and external appearance. The general consensus is that Sousa borneensis is not a valid species, and is a junior synonym of Sousa chinensis (see Jefferson and Van Waerebeek, 2004), and I consider it to be in the synonymy of that species. However, very few specimens of this form of humpback dolphin have been examined, and future studies may show this to be a valid subspecies of Sousa chinensis.

\section{Sousa huangi Wang, 1999}

Wang described a young specimen of humpback dolphin from Behai, southern China, as the new species, Sousa huangi. Earlier, Huang and Fu (1984) had described a specimen from this area in an abstract, but it appears their work was never published. There was no official declaration of a type specimen, but Wang (1999) provided a detailed description of the skeleton of the animal he obtained. His description of the species' supposedly unique characters is dubious, and there is little doubt that any reported differences from Sousa chinensis were simply a result of developmental and individual variation (see Jefferson et al., 2012, for a description of the age- and sex-related variation of these animals). The validity of this species has been soundly rejected (Jefferson and Rosenbaum, 2014), and the name has been placed in the synonymy of Sousa chinensis.

\section{Sousa plumbea (G. Cuvier, 1829) - Indian Ocean humpback dolphin}

\section{Delphinus plumbeus G. Cuvier, 1829}

The two syntype specimens - one adult of $226 \mathrm{~cm}$ and one young calf of $98 \mathrm{~cm}$ - from "Malabar" (India, Bay of Bengal) are stored in the Muséum National d'Histoire Naturelle [Paris Museum] (skulls: MNHN A.3051, A.3053; stuffed skin: CGZ No. 31; Robineau, 1990). Cuvier's type description is quite brief and does not include illustrations. However, figures of the external appearance of the syntype specimens, showing the prominent dorsal hump, were reproduced in Arvy (1972a) and Robineau (1990, 2005). I measured the complete adult skull for the Jefferson and Van Waerebeek (2004) study (Table 3). Sousa plumbea is a valid species, based on the results and conclusions of Jefferson and Rosenbaum (2014), and Delphinus plumbeus is the senior synonym of the newly-resurrected Indian Ocean humpback dolphin. Variant spellings include plumbea.

\section{Delphinus (Steno?) lentiginosus Owen, 1866}

The type specimen of this species was captured at "Waltair" (in present-day Visakhapatnam, at about $18^{\circ} \mathrm{N}$ in central eastern India). The type skull is still in the collection of the Natural History $\mathrm{Mu}-$ seum, London (NHMUK 1866.2.5.2), where it was measured in 1999 as part of the Jefferson and Van Waerebeek (2004) study (Table 3, Fig. 7). Hershkovitz (1966) credited the name to Gray (1866a) for reasons that are not clear to me. It has been challenging to ascertain the affinity of the type specimen of Steno lentiginosa, since it was collected within the currently-understood range of both the plumbea-type and the chinensis-type. A plate illustrating the external appearance of the 2.4-m specimen in Owen's paper shows extensive spotting on the body. It does not give much indication of the prominent dorsal hump that is characteristic of the plumbea-type, although there does appear to be evidence of a keel at the posterior of the dorsal fin (Owen, 1866, fig. 1). Fraser (1966), noted that a taxonomic review of humpback dolphins was "badly needed" and conducted a detailed examination this putative species. His analysis appeared to support Lydekker's (1909) earlier suggestion that Steno lentiginosa is most likely allied with the plumbea-type and not the chinensis-type. Therefore, I tentatively consider this name to be a junior synonym of Sousa plumbea. New molecular evidence suggests that humpback dolphins in the Bay of Bengal are distinct from both chinensis and plumbea, possibly at the species level (Amaral et al., 2017). If Owen's type specimen is found to cluster with Amaral's Bay of Bengal specimens in future molecular studies, then the name lentiginosallentiginosus would be associated with any species or subspecies proposed to describe the Bay of Bengal animals. Variant spellings include lentiginosa.

\section{Sotalia fergusoni Lydekker, 1904}

This species was based on the carcass of a very small $(c a .1 \mathrm{~m})$ dolphin collected at "Trevandrum," India. The specimen consists of the skull and postcranial 


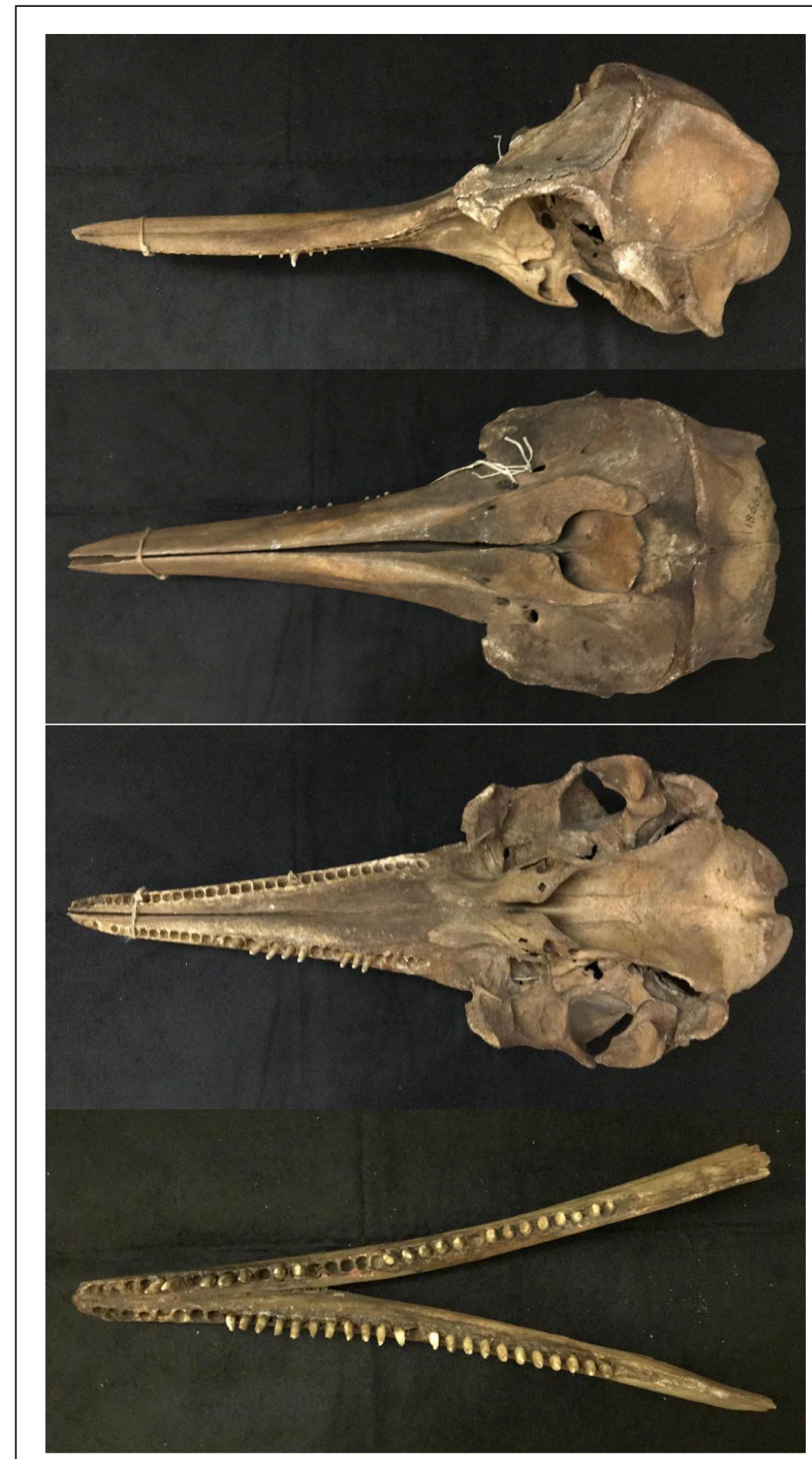

Figure 6

The type specimen of Sotalia borneensis Lydekker, 1901 (NHMUK 1901.2.16.1). 


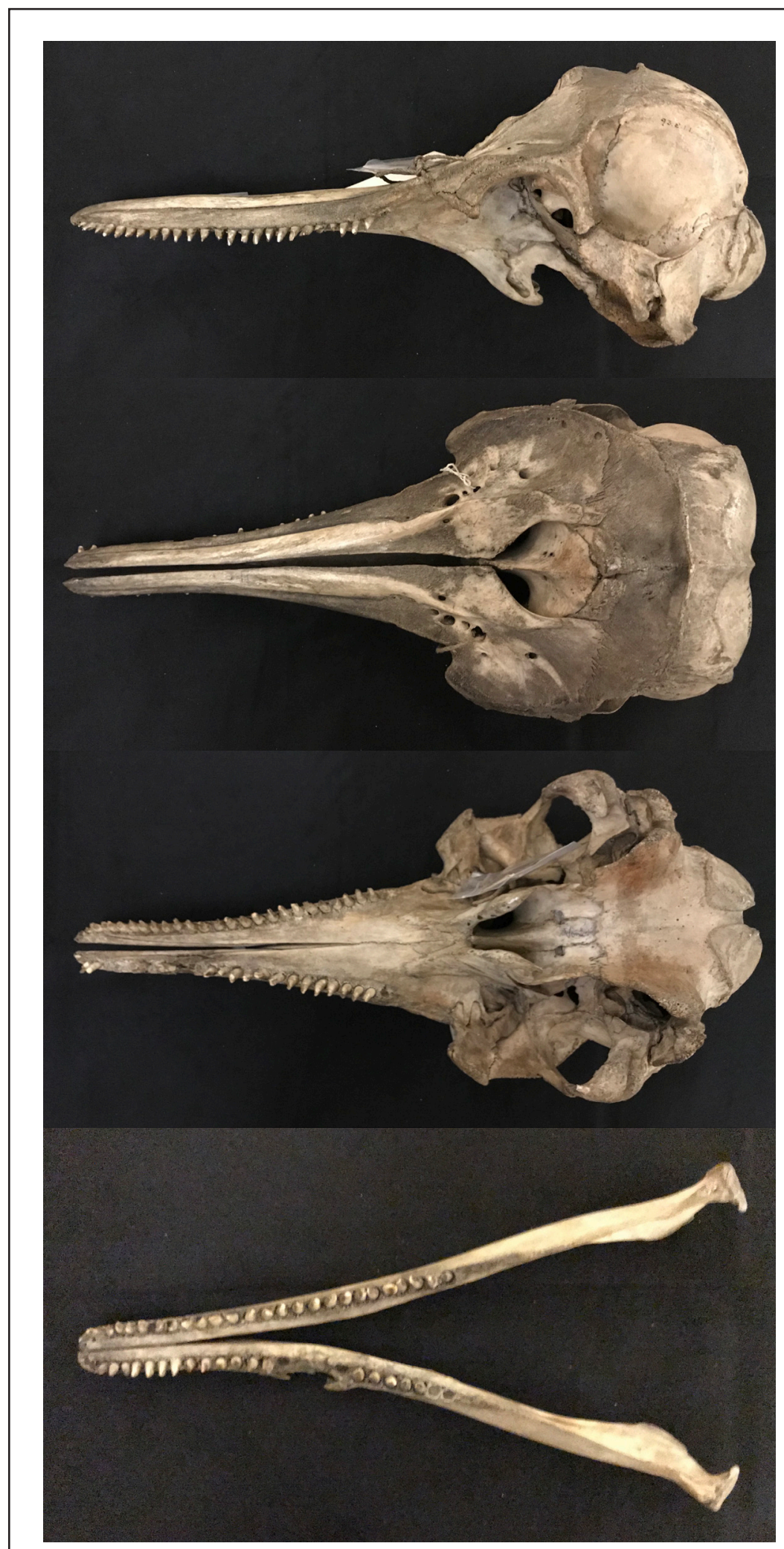

Figure 7

The type specimen of Delphinus (Steno?) lentiginosus Owen, 1866 (NHMUK 1866.2.5.2). 
skeleton of an obviously immature specimen. The type description is moderately detailed, and includes an illustration which shows an apparent dorsal hump. The specimen (skull and skeleton) may have been previously kept in the Trivandrum (Travancore) Museum, but it is now in the holdings of the British Museum (NHMUK 1903.9.12.2). It was examined as part of the Jefferson and Van Waerebeek (2004) study. I consider this name to be a junior synonym of Sousa plumbea.

\section{Stenopontistes zambezicus Miranda-Ribeiro, 1936}

For some years, this species was erroneously considered to be a synonym of Steno bredanensis; however, Brownell (1975) re-examined the skull and placed it in the synonymy of the humpback dolphins (Sousa spp.). The species was described from a specimen (MN 131) in the Museu Nacional, Rio de Janiero, Brazil, which was collected in "Zambezi" (also spelled Zembeze, presumably Zambezia, in present-day Mozambique, on the east coast of central/southern Africa). The type description is detailed and includes multiple photos of the skull. Notwithstanding the objections of Pilleri and Gihr (1976), I consider this name to be a synonym of Sousa plumbea.

\section{Sousa teuszii (Kükenthal, 1892) - Atlantic humpback dolphin}

\section{Sotalia teuszii Kükenthal, 1892}

Hershkovitz (1966) stated that the holotype specimen (a skull from Cameroon, West Africa) was "presumably still in the Jena Natural History Museum." However, it is now located in the collection of the Natural History Museum, London (NHMUK 1893.8.1.1), where I re-examined it (for Jefferson and Van Waerebeek, 2004; Table 3, Fig. 8). A photograph of the skull was published with the type description, and Pilleri and Gihr (1972a) provided additional photos of the type specimen. This name is the senior synonym of the Atlantic humpback dolphin, from West African waters. Variant spellings include teuszi.

\section{Sousa sahulensis Jefferson and Rosenbaum, 2014} - Australian humpback dolphin

\section{Sousa queenslandensis Gaskin, 1972}

Though seemingly based on scant evidence, in 1972 Gaskin correctly speculated that Australian humpback dolphins might eventually be found to be a distinct species or subspecies. He offered the name Sousa queenslandensis if that were indeed found to be the case. However, Gaskin provided no description of characters that would differentiate the taxon. As such, this name violates Article 13 of the International Code of Taxonomic Nomenclature (ICZN, 1999). It is considered to be a nomen nudum, and is therefore not available.

\section{Sousa sahulensis Jefferson and Rosenbaum, 2014}

The Australian humpback dolphin was described by Jefferson and Rosenbaum, with a type specimen (skull) housed at the MTQ (MTQ/JM20036; Table 3). The description is detailed, conducted as part of a global revision of the genus Sousa. It included photographs of the skull and external appearance, measurements with comparisons to other species in the genus, as well as molecular characters and comparisons. Gaskin (1972) had previously suggested that Australian humpback dolphin may turn out to be a separate species, but his name is a nomen nudum (see Sousa queenslandensis Gaskin, 1972). Sousa sabulensis is thus the valid name for the Australian humpback dolphin.

\section{Genus Tursiops Gervais, 1855 - bottlenose dolphins}

\section{Tursiops truncatus (Montagu, 1821) - common bottlenose dolphin}

\section{Delphinus tursio Gunnerus, 1768}

This species was named and described by Gunnerus in 1768, with reference to the illustrations in Klein (1741) which clearly show a common bottlenose dolphin. The name appears to have long been overlooked and forgotten, until it was "rediscovered" and proposed by Kinze (2018) as the valid name for the common bottlenose dolphin. It is the senior homonym of Delphinus tursio Fabricius, 1780, the latter of which has been used occasionally in the twentieth century. However, True (1903) convincingly argued that this latter name was not a bottlenose dolphin (see Delphinus tursio Fabricius, 1780). Assuming that these are in fact two different names (which is not $100 \%$ clear), Gunnerus' Delphinus tursio does not appear to have been used for the bottlenose dolphin since 1899 , thereby satisfying the condition of Article 23.9.2 of the ICZN (1999), and making it appropriate to consider it a nomen oblitum. An explicit proposal to do so (and thereby to conserve Delphinus truncatus Montagu, 1821) has been made (Jefferson, 2021).

\section{Delphinus nesarnack Lacépède, 1804}

Although the Greenlandic name "nesernack" originally meant the "other porpoise" and could refer to several delphinid species, Lacépède's description includes a painting that shows what appears to be a bottlenose dolphin. Delphinus nesarnack had previously been considered to be the senior synonym for the common 


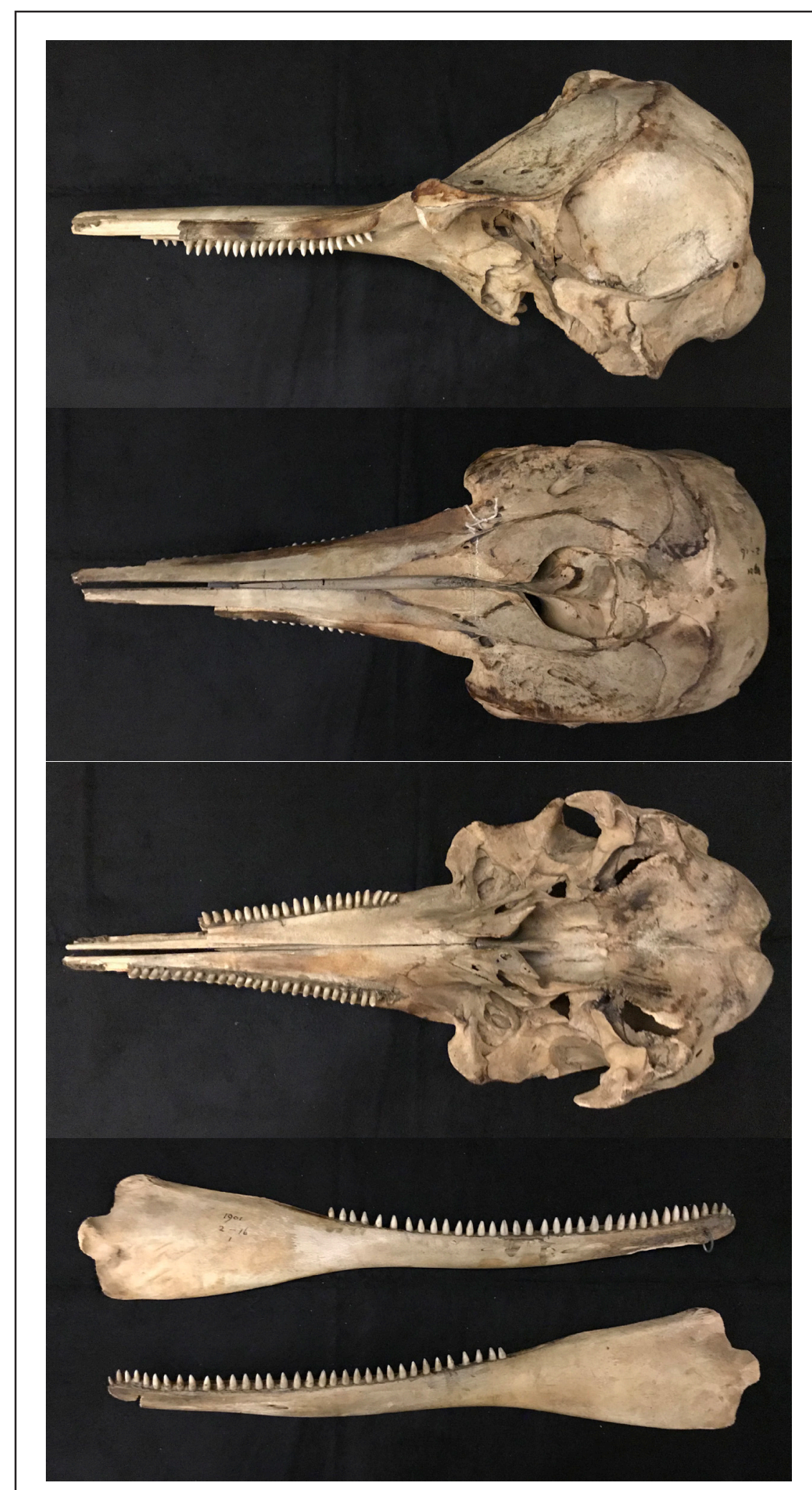

Figure 8

The type specimen of Sotalia teuszii Kükenthal, 1892 (NHMUK 1893.8.1.1). 
bottlenose dolphin, but it had rarely been used for this species since being published in 1804 and seems to have been forgotten. The type specimen was supposedly in the École Nationale Veterinaire d'Alfort (Veterinary School of Alford, near Paris), but it has not been subsequently found, and is presumed lost. Although Hershkovitz (1961) made a case for resurrecting this name for the common bottlenose dolphin, he later changed his mind (Hershkovitz, 1966). Rice (1984) petitioned the ICZN to have this name placed on the Official Index of Rejected and Invalid Specific Names in Zoology, and the suppressed name is now considered to be a nomen oblitum. Variant spellings include nesarnak.

\section{Delphinus truncatus Montagu, 1821}

The species is based upon a detailed description of a skull from a specimen collected in 1814 from Duncannon Pool, about 5 miles $(8 \mathrm{~km})$ up the Dart River, in the region of Totness, England. The description contains an illustration of the skull (reproduced in Pilleri and Arvy, 1981), and the type specimen is still present in the NHMUK (No. 353a; Table 3). Although not the senior synonym, this species name has been in almost universal use for the common bottlenose dolphin in the twentieth and twenty-first centuries, since the note by True (1903) was published stating that this was probably the "correct" name of the common bottlenose dolphin. Although antedated by two other names, Rice (1984) petitioned the ICZN to have this name conserved, and the name is now considered to be a nomen conservandum (Tubbs, 1986). It is the valid name for the common bottlenose dolphin. Variant spellings include troncatus.

\section{Delphinus compressicauda Lesson, 1828}

Lesson described Delphinus compressicauda from a specimen harpooned in the central tropical Atlantic Ocean (off the coast of Brazil at approximately $4^{\circ} \mathrm{S}$, $\left.26^{\circ} \mathrm{W}\right)$; it is uncertain if the specimen was preserved. The holotype description is rather detailed, but there are no accompanying figures. Tooth counts (44 upper, 46 lower) suggest that this was a bottlenose dolphin, and the name is considered to be in the synonymy of Tursiops truncatus.

\section{Delphinus eurynome Gray, 1846}

This species was briefly described by Gray from a skull from an unknown locality (although NHMUK records list it as the Bay of Bengal) in the NHMUK (No. 356a; Table 3), and illustrated clearly in his 1846 monograph (plate 17). The illustration shows a common bottlenose dolphin skull, and recently Kurihara and Oda (2007) confirmed it as a specimen of Tursiops truncatus. The name is considered to be a junior synonym of Tursiops truncatus.

\section{Delphinus metis [No. 1] Gray, 1846}

Gray described and illustrated the skull of this species in 1846 under the name Delphinus metis. He listed the type locality as unknown, but later (Gray, 1871) listed it as coming from "West Africa." Unfortunately, on the following page in the original publication (Gray, 1846), he used the same name for another species of dolphin (the Clymene dolphin [Stenella clymene]). This makes Delphinus metis [No. 1] the senior homonym, and Delphinus metis [No. 2] a junior homonym (see below under Stenella clymene for a detailed history of these names). The type specimen of Delphinus metis [No. 1] is still in the NHMUK (No. 357a; Table 3). The drawings of the skull (plate 18) make it clear that Delphinus metis [No. 1] is a common bottlenose dolphin. The name is considered to be a junior synonym of Tursiops truncatus.

\section{Delphinus cymodoce Gray, 1846}

Gray described this species very briefly in 1846 , based on a skull in the NHMUK (No. 355a; Table 3) from an unknown locality. He included a plate with drawings of the skull, which allow identification as a common bottlenose dolphin. In a later revision of the cetaceans (Gray, 1871), he listed the origin of the specimen as "River Uragua. Mus. Buenos Ayres" (the River Uragua is in Uruguay). This name is considered to be a junior synonym of Tursiops truncatus. Variant spellings include symodoce, cymodice, and symodice.

\section{Delphinus tursio obtusus Schlegel, 1862}

Although this name is sometimes considered to be a junior synonym of Tursiops truncatus, it is not a new species name (as it has sometimes erroneously been treated), but a subspecies name, and therefore is outside the scope of this review.

\section{Delphinus erebennus Cope, 1865}

Cope (1865a) described this species of bottlenose dolphin primarily from perceived vertebral differences, based on a skeleton collected from the coast at Red Bank, near Philadelphia, Pennsylvania. The holotype specimen is in the ANSP (No. 3020, partial postcranial skeleton; Koopman, 1976). The name is considered a junior synonym of Tursiops truncatus. 


\section{Tursiops gillii Dall, 1873}

In a very brief account, Dall described this species from a specimen collected from Monterey, California. The type specimen, the mandible only (along with outline drawings of the external appearance by Capt. C. M. Scammon), is preserved in the USNM (No. 13022). Although the name has been used in numerous publications on Pacific bottlenose dolphins, it is not considered a valid species, and the name is regarded as a junior synonym of Tursiops truncatus. See Fisher and Ludwig (2016) for history. Variant spellings include gilli.

\section{Tursiops subridens True, 1884}

True introduced this name for U.S. east coast bottlenose dolphins, without much description; although he did mention casts of two specimens (USNM 13317 and 13318). In Flower's (1884) monograph on delphinids, the species was described from a specimen from Cherry Point, Virginia. The description is extremely brief and no illustrations were provided in either paper. Interestingly, True (1889) does not mention the species in his comprehensive review of the Delphinidae, published five years later. There are two syntypes in the USNM (No. 16504 - skull and mounted skeleton, and 16505 - skull and mounted skeleton), as well as several casts (probably USNM 13317 and 13318). Although this species usually appears in the synonymy of Tursiops truncatus, True's (1884) original name is probably best considered a nomen nudum.

\section{Tursiops parvimanus P. J. Van Beneden, 1886}

Van Beneden introduced this name for a dolphin specimen in the NHMD in Copenhagen (No. 4327). However, the species was not described and the account only said that there was a skeleton from the Adriatic and apparently a stuffed skin. No illustrations were provided. Lütken (1887) believed it to be a bottlenose dolphin (Tursiops sp.), but due to the lack of identifying information, this name should actually be considered a nomen nudum.

\section{Tursiops parvimanus Lütken, 1887}

Lütken provided a description of this species, giving measurements of what is considered the type specimen, which was presumably the same one earlier mentioned by Van Beneden (1886). The specimen from the Adriatric Sea was said to be a small form, and several supposedly diagnostic skeletal characters were given, prompting True (1889) to consider this a valid species. It is no longer recognized, and is now considered to be a junior synonym of Tursiops truncatus.

\section{Tursiops gephyreus Lahille, 1909}

Lahille provided a detailed description with measurements, multiple illustrations, and skull photos of this proposed new species from two syntypes - male and female specimens collected by Nicolas Antieri at Rio de la Plata and Punta Lara, Argentina. A lectotype (skull and mounted skeleton of the female specimen; the male has been lost) has been designated and is still present in the MACN-Ma (No. 54.113; Varela et al., 2010). The name has been used periodically at the species level by South American researchers, and there have been several recent suggestions that the form is either a valid species or subspecies. Wickert et al. (2016) and Hohl et al. (2020) suggested that there are indeed species-level differences and that the name should be resurrected. However, this has not been accepted by the Committee on Taxonomy (SMM, 2020), and the name is currently considered to be a junior synonym of Tursiops truncatus and the senior synonym of the subspecies Tursiops truncatus gephyreus (the coastal form of bottlenose dolphin from the western South Atlantic - see Costa et al., 2016, 2021; Wang et al., 2021).

\section{Tursiops dawsoni Lydekker, 1909}

A fairly detailed description serves to identify this species, which includes measurements of two specimens and a painting of the external appearance. The specimens were collected from Trivandrum, Travancore coast, India, and the skeleton of one of them was sent to the British Museum to serve as the type for the species (NHMUK 1908.8.13.1; Table 3). The other specimen might be in the Trivandrum Museum, India (needs to be confirmed). Ostelogical differences are used to distinguish the new species from others known at the time, but these are not convincing. According to Lydekker, the two specimens measured $2.74 \mathrm{~m}$ and $2.85 \mathrm{~m}$ in total length, both above the known maximum for Tursiops aduncus (Wang, 2018). Based on these measurements, the features in the illustration of the body, and examination of one of the syntypes in the NHMUK, this species is a junior synonym of Tursiops truncatus. Kurihara and Oda (2007) also confirmed NHMUK1908.8.13.1 as Tursiops truncatus.

\section{Tursiops nuuanu Andrews, 1911}

This species was based on a bottlenose dolphin specimen collected from the eastern tropical Pacific (from $12^{\circ} \mathrm{N}, 120^{\circ} \mathrm{W}$ ), as well as several skulls found on beaches in the Gulf of California, Mexico (Andrews, 1911a). The type description is detailed, including measurements, and the holotype skull is still in the American Museum (AMNH 35045; Goodwin, 1953). 
However, the species is not considered valid. The name is considered to be a junior synonym of Tursiops truncatus.

\section{Tursiops maugeanus Iredale and Troughton, 1934}

Iredale and Troughton named this species from a specimen from Tasmania, southern Australia. There is no description of identifying features, and no photos or illustrations were provided. There apparently is a type specimen in the QVMAG. The name has generally been considered a junior synonym of Tursiops truncatus. However, since there is not an adequate description, it should be considered a nomen dubium until the type can be identified with a particular species of bottlenose dolphin.

\section{Tursiops aduncus (Hemprich and Ehrenberg, 1832) - Indo-Pacific bottlenose dolphin}

Delphinus aduncus Hemprich and Ehrenberg, 1832

The type description is in a short footnote on the last page of an unpaginated fascicle with the subtitle "HERPESTES leucurus $\mathrm{H}$. et E" (Hemprich and Ehrenberg, 1832). Although the species is sometimes credited to W. F. Ehrenberg alone, the footnote lists the species as "Delphinus aduncus H. et E.," which explicitly indicates that the proper authorship is Hemprich and Ehrenberg (note that nineteenth-century authors consistently listed it this way - see Gray, 1846, 1850, 1866a; Van Beneden and Gervais, 1880; Flower, 1884; True, 1889). The year has also been controversial (variously listing 1832 or 1833); however, despite claims to the contrary, 1832 has been settled on as the correct year of publication (see Perrin et al., 2007a), making the full citation "Hemprich and Ehrenberg, 1832." For a long time it was believed that no type specimen existed, but the holotype specimen, a skull, was discovered by P. J. H. van Bree, and a detailed description (complete with photos, illustrations, measurements, and molecular data) was published by Perrin et al. (2007a). The type was recently in the Museum für Naturkunde, Berlin, Germany (ZMB 66400), but could not be found by the curator in 2019 (Christiane Funk, in litt.). The type specimen was collected on Belhosse Island of the Dahlak Archipelago of Ethiopia, in the Red Sea, at approximately $15^{\circ} 25^{\prime} \mathrm{N}, 40^{\circ} 43^{\prime} \mathrm{E}$. This name is the senior synonym and valid name for the Indo-Pacific bottlenose dolphin.

\section{Delphinus hamatus Wiegmann, 1840}

Wiegmann published a plate showing two views of the skull of this species (plate 369), which he credited to Hemprich and Ehrenberg. This plate apparently rep- resents the first use of this species name. The skull is that of a bottlenose dolphin, almost certainly Tursiops aduncus, showing a distinct premaxillary "pinch" or compression (diagnostic of Tursiops aduncus). However, since there was no description of distinctive features (and no reference to such), it might appear not to be available. But under ICZN Article 12.2.7, the name is indeed available.

\section{Delphinus abusalam Rüppell, 1842}

The detailed description, including measurements and tooth counts, and accompanying illustration of the external appearance and skull leave no doubt that this nominal species is an example of Tursiops aduncus. The type specimen (a female) was collected from the Red Sea, and is represented by a skin and skull in the Seckenberg Museum (SMF 4337). This name belongs in the synonymy of the Indo-Pacific bottlenose dolphin. Variant spellings include salam.

\section{Delphinus hamatus Wagner, 1847}

Wagner provided this name for a dolphin species as a replacement for Delphinus abusalam (= Tursiops aduncus). It is sometimes cited as Wiegmann, 1840, apparently because the illustration of the species by Wiegmann (plate 369) was available to some people before the description by Wagner was published. Based on the paintings of external appearance and the skull, this species is what is now known as the IndoPacific bottlenose dolphin; therefore this name is a junior synonym of Tursiops aduncus.

\section{Tursiops catalania Gray, 1862}

Gray described this species from two syntype skulls in the British Museum (NHMUK 1862.6.6.13 and 1862.6.6.14; Table 3). They were collected from Cape Melville, within the Great Barrier Reef, and from Cape Flattery, northeastern Australia. The description is not very detailed (but does contain some measurements), and there are no illustrations provided. Although the name might be considered a nomen dubium by some, it has been confirmed that these skulls are examples of the Indo-Pacific bottlenose dolphin (Kurihara and Oda, 2007). The name is here considered a junior synonym of Tursiops aduncus.

\section{Delphinus (Steno?) maculiventer Owen, 1866}

The holotype specimen collected by Walter Elliot from Waltair, India, is well illustrated and described in detail in Owen's monograph. The type specimen may still be at the NHMUK, but it could not be located in the collection in 2019. Owen's description and illustration of the external form and coloration make it 
clear that this species corresponds to Tursiops aduncus, and the name is a junior synonym of that species.

\section{Delphinus (Steno?) gadamu Owen, 1866}

Owen described Delphinus gadamu from a specimen collected at Vizagapatam, India, by W. Elliot. Owen's type description is quite detailed, with measurements, tooth counts, and illustrations of the whole animal and details of the skull. The skull is still in the NHMUK (No. 1866.2.5.3; Table 3), and recently Kurihara and Oda (2007) confirmed it as an Indo-Pacific bottlenose dolphin. The illustrations and described details show that this species is a junior synonym of Tursiops aduncus. Variant spellings include gudamu.

\section{Delphinus salam P. J. Van Beneden, 1886}

Van Beneden used this name with no description or illustration, only saying that it occurs in the "mer Rouge" (Red Sea). Often considered a nomen nudum, this name is apparently a lapsus calami for Delphinus abusalam, and therefore belongs in the synonymy of the Indo-Pacific bottlenose dolphin.

\section{Tursiops fergusoni Lydekker, 1903}

Lydekker provided a fairly detailed description of this species of dolphin, based on a specimen collected from Trivandrum, India. Some measurements were given, as well as a detailed color painting of the external appearance. The description indicates that the under-surface was "plumbeous" in color and marked with "streaks instead of spots." This suggests that this name is associated with the Indo-Pacific bottlenose dolphin, and I therefore tentatively consider this name to be a junior synonym of Tursiops aduncus. The skull was supposedly being sent to the NHMUK, but it remains to be confirmed whether the specimen is part of that collection (it was not located there on a visit in 2019).

\section{Tursiops australis Charlton-Robb et al., 2011}

This new species was proposed for a geographical form of bottlenose dolphin endemic to the coastal waters of southern Australia, called the Burrunan dolphin. A detailed description and comparison with other bottlenose dolphins from the region was presented, and it included photos, measurements, and molecular information. The type specimen is identified as QVMAG 1360. Although there is little doubt that this animal represents a well-marked geographic form of bottlenose dolphin, the evidence presented for it being a distinct species has so far been considered inadequate and unconvincing. The species has not been accepted by the Committee on Taxonomy (SMM, 2020). Proper global comparisons with other Tursiops spp. have recently been made, and these indicate that Tursiops australis should be considered to be a junior synonym of Tursiops aduncus (Moura et al., 2020).

\section{Genus Stenella Gray, 1866 - spotted, spinner, and striped dolphins}

\section{Stenella longirostris (Gray, 1828) - spinner dolphin}

\section{Delphinus longirostris Gray, 1828}

This is not Delphinus longirostris G. Cuvier, 1829, which is in the synonymy of the common dolphin (Delphinus delphis). Gray described this species from a type specimen obtained from an unknown locality. Although there is a label on the skull suggesting it came from the Cape of Good Hope, there may have been confusion with its homonym, Delphinus longirostris Cuvier (which was indeed collected from the Cape of Good Hope). So, this location is not considered to be reliable, and the type locality of Delphinus capensis Gray is thus uncertain (see van Bree and Perrin [1977] and Smeenk et al. [1996] for history). Gray (1846) caused great confusion when he erroneously synonymized several nominal species, including his Delphinus longirostris and Delphinus longirostris Cuvier. The holotype specimen of Gray's species (a skull) was originally in the private collection of D. Brookes in London (see Brookes, 1828), but was sold and is now in the Leiden Museum (RMNH 8676). Van Bree and Perrin (1977) provided a detailed description, sorted-out history, and illustration of the holotype. This name is the senior synomym and valid name of the spinner dolphin.

\section{Delphinus roseiventris Wiegmann, 1844}

Wiegmann published a plate of the external body, which represents the first use of this species name (plate 360 , fig. 1). The painting in the plate is a good rendition of a spinner dolphin. Since there was no description of distinctive features (and no reference to such), it might appear to be not available, but under ICZN Article 12.2.7, the name is indeed available. There is a detailed description of this species in Jacquinot and Pucheran (1853), which includes an accurate illustration of the body form and coloration (plate 22, fig. 2). This species represents a dwarf form of spinner dolphin, based on several specimens collected in the northern Arafura Sea in 1839 and deposited in the MNHN in Paris (skull: CAC: A.3026; skeleton: JAC: 1880-553; Robineau, 1990). One of these skulls in the Paris $\mathrm{Mu}-$ seum (MNHN 1882-104) was formerly considered the holotype, but the specimen has been lost or cannot be currently identified. Perrin et al. (1999) reviewed the complex nomenclatorial history of these specimens and provided a detailed summary. Although they errone- 
ously credited Wagner (1847) for the species name (a text description of roseiventris was not included in that volume), they helped to stabilize the taxonomy by designating a neotype specimen (skull, MNHN A-3026). The name is a junior synonym of Stenella longirostris and this form now is also recognized as a subspecies, the dwarf spinner dolphin (Stenella longirostris roseiventris) (Perrin et al., 2007b). Variant spellings include roseiventer.

\section{Delphinus alope Gray, 1846}

Gray described this species from a skull collected at an unknown locality. There is no text description of the species, but there is a good illustration (plate 32) that can be used to identify the skull as that of a spinner dolphin. The type specimen was in the Haslar Hospital Museum, London, but is now in the NHMUK (No. 1847.7.6.2; Table 3). The species is now considered a synonym of Stenella longirostris.

\section{Delphinus microps Gray, 1846}

Gray described this species in a brief account from a skull reportedly at the Haslar Hospital Museum, London, and collected from an unknown locality. The skull was accurately illustrated in Gray (1846), providing good evidence that this species name is a synonym of the spinner dolphin. The type specimen has been transferred to the British Museum (NHMUK 349a; Table 3), where it still resides. The name is a junior synonym of Stenella longirostris.

\section{Delphinus stenorhynchus Gray, 1866}

This species was described by Gray (1866a) from a skull in the NHMUK (No. 1850.6.5.9 or 1471a; Table 3) from an unknown locality. The description is very brief and there is no illustration, thereby suggesting that it perhaps should be considered a nomen nudum. However, Perrin and Gilpatrick (1994) considered it to be in the synonymy of the spinner dolphin, apparently based on the description of the very long rostrum and stated similarity to Delphinus microps (known to be a spinner dolphin), and I confirmed it as a spinner dolphin specimen in 2019. Therefore this name is a junior synonym of Stenella longirostris. Variant spellings include stenorhyncha.

\section{Stenella attenuata (Gray, 1846) - pantropical spotted dolphin}

\section{Delphinus velox G. Cuvier, 1829}

This species was based on a dolphin captured by J. J. Dussumier in the Indian Ocean between Sri Lanka (then called Ceylon) and the equator. The holotype (a mounted skin) is in the Paris Museum (MNHN CGZ No. 17 of the Catalogue de la Galerie de Zoologie). Robineau (1990) provided measurements of the stuffed skin, and an unpublished manuscript by J. J. Dussumier (MNHN manuscript No. 894; Arvy, 1972b) provides an outline of the type specimen, which clearly shows it to be a species of Stenella. Although Perrin et al. (1987) suggested that it is a representative of the pantropical spotted dolphin (and therefore would technically be the senior synonym of that species), because the name has not been used since the 1800 s, they considered it should represent a nomen oblitum. The name has since been suppressed by the ICZN (1991).

\section{Delphinus brevimanus Wiegmann, 1840}

Wiegmann published a plate showing what appears to be the skull of a pantropical spotted dolphin, which represents the first use of this species name (plate 361, fig. 2). However, since there was no description of distinctive features (and no reference to such), the name might appear to be unavailable. But under ICZN Article 12.2.7, the name is available. The name has since been suppressed by the ICZN (1991) and is a nomen oblitum.

\section{Delphinus pseudodelphis Wiegmann, 1840}

Wiegmann published a plate showing various views of the skull (plate 358). The holotype, apparently a specimen of Stenella attenuata, is in the ZMB, Berlin (No. 12009). Since the plate did not include any description of distinctive features (and no reference to such), some might think that the name is not available, but under ICZN Article 12.2.7, the name is indeed available. The name has since been suppressed by the ICZN (1991), however, and is now a nomen oblitum. Variant spellings include pseudo-delphis and pseudodelphinus.

\section{Delphinus pseudodelphis Schlegel, 1841}

This species was originally based upon a plate by Wiegmann (1840, plate 358), which is part of the series that ultimately resulted in the publication of the text in Wagner (1847). Therefore the date associated with this species has been confusing and controversial. There was no description in Wiegmann, but a short description of the skull of the species did appear in Schlegel (1841b). Wagner (1847) did later discuss the species in some detail and referenced the plate from Wiegmann. After thorough consideration, Perrin et al. (1987) considered the species to be a representative of the pantropical spotted dolphin, but because the name has only been used once since 1900 (by Oliver, 1922), they proposed that the name be considered a nomen obli- 
tum. The name has since been suppressed by the ICZN (1991). Spelling variations include pseudo-delphis.

\section{Delphinus attenuatus Gray, 1843}

Gray (1843a) listed this name in his 1843 list of mammalian species in the British Museum, but with essentially no description and no illustration, and therefore the name should be considered a nomen nudum.

\section{Steno attenuatus Gray, 1846}

In this publication, Gray finally provided a description of the species he earlier called Delphinus attenuatus but with no description, and by doing so made the name available. The holotype skull is in the British Museum (NHMUK 347b; Table 3) and is from an unknown locality. It is clearly allied with the pantropical spotted dolphin, and Perrin et al. (1987) felt that the specimen may have been from India. In any event, this name is the valid name used for the pantropical spotted dolphin. Although there are several names that antedate it (Delphinus velox, Delphinus pseudodelphis, and possibly Delphinus brevimanus), Perrin et al. (1987) proposed that Stenella attenuata be used as the valid name for the pantropical spotted dolphin. It has been retained by the ICZN as a nomen conservandum. Gray's (1843a) earlier use of Delphinus attenuatus, without any description, is a nomen nudum. Spelling variations include attenuata.

\section{Delphinus albirostratus Peale, 1849}

This species was described from a holotype specimen collected near the Phoenix Islands $\left(2^{\circ} 47^{\prime} \mathrm{S}, 174^{\circ} 13^{\prime} \mathrm{W}\right)$ during the U.S. Exploring Expedition of 1838-1842 (note that Peale's volume was later withdrawn, due to a belief that it contained too many taxonomic errors; see p. 343 in Philbrick, 2003). In the later re-issued version of this volume (Cassin, 1858, plate 6, fig. 2), virtually the same description appears under the name Lagenorbynchus coeruleoalbus. The type was apparently destined for the USNM, but was not on Peale's list of specimens (Fisher and Ludwig, 2016); it is no longer known to exist. The painting in Cassin's plate shows that this name should be regarded as a junior synonym of Stenella attenuata.

\section{Delphinus? microbrachium Gray, 1850}

This species was based on a specimen collected near Singapore, which was described briefly by Gray. The holotype skull is still in the Paris Museum (MNHN 1882-113, the same specimen on which Delphinus brevimanus Jacquinot and Pucheran, 1853 was based). The specimen is a pantropical spotted dolphin; since the name has not been used since 1900, Perrin et al.
(1987) considered it a nomen oblitum. Since Stenella attenuata is the valid name of the pantropical spotted dolphin, Delphinus microbrachium is a junior synonym of Stenella attenuata.

\section{Delphinus brevimanus Jacquinot and Pucheran, 1853}

This species was based on a specimen collected near Singapore or in the Strait of Banka, from a very short description (but including a good figure of the external appearance). The holotype (stuffed skin) is still in the Paris Museum (MNHN CGZ No. 21 or MNHN 1882-113, the same specimen on which Delphinus? microbrachium Gray, 1850 was based). The specimen is a pantropical spotted dolphin, but since the name has not been used since 1900, Perrin et al. (1987) considered it a nomen oblitum. The name has been suppressed by the ICZN (1991).

\section{Steno capensis Gray, 1865}

This is not Delphinus capensis Gray, 1828, which is in the synonymy of the common dolphin. The type specimen of this species was collected off the Cape of Good Hope, and the type (skull) is still in the British Museum (NHMUK 1869.4.5.5; Table 3; Gray, 1865a). Perrin et al. (1987) confirmed that this is a specimen of the pantropical spotted dolphin, and the name is a junior synonym of Stenella attenuata.

\section{Clymene punctata Gray, 1866}

Gray (1866c) provided a short account that mostly described the skull of this species, but also included a crude drawing of the external form and coloration. The type specimen of this species was collected from Cape Verde, off western Africa (reported to be $\left.16^{\circ} 40^{\prime} \mathrm{N}, 21^{\circ} \mathrm{W}\right)$. It was present in the Liverpool Public Museum (Walker's No. 3) in the 1880s (True, 1889). Tooth counts and color pattern information in True (1889) and the type description identify it as a pantropical spotted dolphin (Perrin et al., 1987). Unfortunately, the holotype skull, transferred to Berlin, was destroyed during World War II. Variant spellings include punctatus.

\section{Steno consimilis Malm, 1871}

Although sometimes considered erroneously to be in the synonymy of the spinner dolphin, the excellent illustrations of the skull in Malm's account show it clearly to be a specimen of the pantropical spotted dolphin (Perrin et al., 1987). The skull from Madagascar is apparently still in the Technological Institute, Norrkoping, Sweden, though it does not appear to have been examined recently. This name is considered a synonym of Stenella attenuata. 


\section{Prodelphinus graffmani Lönnberg, 1934}

Lönnberg provided a detailed description of this new species. The type specimen was collected off Acapulco, Mexico, and is in the State Museum of Natural History, Stockholm. It consists of the mounted skin and a badly damaged skull (from a gunshot used to kill the specimen in 1933). This name is a synonym of the pantropical spotted dolphin. It is now recognized as a subspecies, the coastal form of the pantropical spotted dolphin, Stenella attenuata graffmani (see Perrin, 1975).

\section{Stenella frontalis (G. Cuvier, 1829) - Atlantic spotted dolphin}

\section{Delphinus frontalis G. Cuvier, 1829}

A short description by Cuvier, with no illustrations, serves as the type description for this species. The holotype specimen was harpooned off Cape Verde, western Africa (approximately $15^{\circ} \mathrm{N}, 24^{\circ} \mathrm{W}$ ) by J. J. Dussumier in 1825 , and for many years its affinity remained controversial. The type specimen is still in the Paris $\mathrm{Mu}-$ seum (skull: MNHN A3035; stuffed mounted skin: CGZ No. 25). Robineau (1990) provided photos of the skull and measurements of the stuffed skin. Perrin et al. (1987) reviewed the history of this species and confirmed that it represents an Atlantic spotted dolphin. The name Delphinus frontalis is therefore considered the senior synomym and valid name of the Atlantic spotted dolphin.

\section{Delphinus froenatus F. Cuvier, 1836}

In 1836, F. Cuvier (note that his brother, Georges Cuvier, is sometimes incorrectly given credit for the species; also the year is sometimes incorrectly cited as 1829) described this species from a holotype specimen harpooned by J. J. Dussumier off Cape Verde in 1827. The collection locality was approximately $15^{\circ} \mathrm{N}, 24^{\circ} \mathrm{W}$. For many years its exact affinity remained controversial. The type specimen (skull) is still in the Paris $\mathrm{Mu}$ seum (MNHN A.3034). An unpublished manuscript by Dussumier (MNHN manuscript No. 894 - Arvy, $1972 \mathrm{~b}$ ) shows an outline of the type specimen, clearly a species of Stenella. True (1889) and Fraser (1950) provided measurements of the holotype skull. Perrin et al. (1987) and Robineau (1990) both reviewed the history of this species, and confirmed that it is an Atlantic spotted dolphin. The name Delphinus froenatus is therefore a junior synomym of Stenella frontalis. Variant spellings include fraenatus, frenatus, and fraenata.

\section{Delphinus doris Gray, 1846}

Gray provided a short account of this new species, which includes good drawings of the skull (plate 20).
The holotype skull (in the British Museum, NHMUK $352 \mathrm{a}$; Table 3) is from an unknown location. It was identified by Perrin et al. (1987) as an Atlantic spotted dolphin, and this species name is therefore a junior synonym of Stenella frontalis.

\section{Delphinus plagiodon Cope, 1866}

Cope provided a moderately-detailed account of this species, focusing on the characters of the skull, including some measurements. The type specimen (a skull) was obtained from an unknown locality (possibly the U.S. east coast), and is still in the Smithsonian collection (USNM 3884). Perrin et al. (1987) included the type in their discriminant analysis, and found that it was a specimen of Stenella frontalis. This name is a junior synonym of Stenella frontalis.

\section{Stenella coeruleoalba (Meyen, 1833) - striped dolphin}

\section{Delphinus coeruleo-albus Meyen, 1833}

Meyen described this species in a somewhat detailed account, based on a specimen harpooned from the region of the Rio de la Plata in Argentina or Uruguay. The accompanying illustration of the external appearance (reproduced in Pilleri and Arvy, 1981) is very detailed and though the body proportions are a bit off, the color pattern is shown quite accurately, depicting a striped dolphin without doubt. The complete skeleton of the holotype was deposited in the Berlin Royal Museum of Anatomy, but is now in the ZMB, Berlin (No. 51226). This name is therefore the senior synonym and valid name of the striped dolphin. Variant spellings are caeruleo-albus, caerulo-albus, caeruleoalbus, caeruleoalba, and coeruleoalbus. The species name is now spelled coeruleoalba.

\section{Delphinus styx Gray, 1846}

Gray described this species in a short account, based upon a skull in the NHMUK, apparently collected from an unknown location in southern or western Africa. The type specimen is well illustrated, clearly indicating that it is a striped dolphin. Gray stated that it was "very like D. Euphrosyne." The type may have subsequently been lost, as I could not locate it in the collection during a 2019 visit. The name is a junior synonym of Stenella coeruleoalba. Variant spellings include stylx.

\section{Delphinus euphrosyne Gray, 1846}

This species was described from a skull collected from an unknown locality (NHMUK records list it as from near Rio de la Plata). Gray said the type specimen was 
in the Museum of Norwich (no number), but was apparently later transferred to the Hunterian Museum, and is now in the NHMUK (No. 1920.5.13.1; Table $3)$. Although the description is not highly detailed, there is a plate (plate 22) that shows the skull well, indicating it is a striped dolphin. The name is now a junior synonym of Stenella coeruleoalba. Variant spellings include euphrosine.

\section{Delphinus holböllii Nilsson, 1847}

Although apparently first mentioned in a lecture by D. Eschricht in 1847 , it was not until later that year that the name was published with a description by S. Nilsson. It was based on the complete mounted skeleton of a young dolphin specimen from southwestern Greenland. Van Bree (1973a) provided a detailed account of the history of this nominal species, and redescribed and photographically illustrated the skull of the type specimen, which at the time was still in the collection of the ZMA (UZM-Kobenhavn CN 16*). The type is now housed in the NHMD, Copenhagen (No. 4326). There is also a good photo of the skull, as well as historical notes, in Kinze (2011). The name is a junior synonym of Stenella coeruleoalba. The proper spelling of the species name, according to ICZN rules, would be holboellii (without the umlaut, but adding the "e"). Variant spellings include bolbollii.

\section{Delphinus lateralis Peale, 1849}

This species was based on a specimen collected at sea in the North Pacific during the U.S. Exploring Expedition, at $13^{\circ} 58^{\prime} \mathrm{N}, 161^{\circ} 22^{\prime} \mathrm{W}$, southwest of the Hawaiian Islands (note that Peale's volume was later withdrawn, due to a belief that it contained too many taxonomic errors - see p. 343 in Philbrick, 2003). In the later reissued version of this volume (Cassin, 1858), virtually the same description appears under the name Lagenorhynchus lateralis. The description and figure published in Cassin (1858, plate 7, fig. 1) leave no doubt that this is a junior synonym of Stenella coeruleoalba. The type specimen, likely originally intended to be deposited in the USNM, apparently was lost. It was not on Peale's list of specimens from the voyage (see Fisher and Ludwig, 2016).

\section{Delphinus tethyos Gervais, 1853}

Gervais described this species from a specimen collected from Valreas, at the mouth of the Orb River, Herault, France, in 1852. The type description is not very detailed, but there is a good illustration showing several views of the skull, including a view of the underside of the cranium. This indicates that the skull is of a striped dolphin. The type specimen is still in the
MNHN (No. A.3021). The name is considered a junior synonym of Stenella coeruleoalba.

\section{Delphinus marginatus Duvernoy in Desmarest, 1856}

This species was named from several specimens collected from a stranding of a large dolphin group at Dieppe, France, in 1854. There was little in the way of description in Duvernoy's account, but the figure of external appearance (plate 29, fig. 1) clearly shows a striped dolphin (Desmarest, 1856, 1874). In the same year, Pucheran (1856) provided a detailed description (credited to Duvernoy) with a very detailed and accurate illustration (plate 25), which confirms the species as a striped dolphin. Duvernoy mentioned four specimens "sent to the museum," but there are only two represented in the Paris Museum collection. The two syntypes are at the MNHN (stuffed skin: CGZ No. 9; skull and skeleton: CAC: A.7946; Robineau, 1990). There has been some controversy over the authority for this species, but Robineau (1990) made a convincing case that the Desmarest (1856) reference appeared before Pucheran (1856), the latter of which was published in December of that year. The name represents a junior synonym of Stenella coeruleoalba, and it is also the senior homonym of Delphinus marginatus Lafont, 1868.

\section{Delphinus mediterraneus Loche, 1860}

This species is based on a specimen captured in 1860 in the harbor of Algiers, Algeria. Although there has been some controversy about the affinity of this species, Loche's fairly detailed color pattern description clearly identifies it as a striped dolphin (Perrin et al., 1987). In addition, Loche included a plate that shows a lateral view of the external morphology and coloration, and there is no mistaking that this is a striped dolphin. The type (skull and complete skeleton) remains in the MNHN (JAC: 1860-132), and Robineau (1990) provided some measurements of the skull. Variant spellings include mediterranea.

\section{Delphinus asthenops Cope, 1865}

Cope's (1865b) moderately detailed original description of the skull allies this species with the striped dolphin. There are no illustrations provided. Examination of the syntypes from an unknown location, said to be from the "Morton Coll" (syntypes in the Museum of the Peabody Academy, National Academy of Sciences, Philadelphia, ANSP 2595 and 2596, both skulls; Koopman, 1976) by Perrin et al. (1987) confirmed this. The name is a junior synonym of Stenella coeruleoalba. Variant spellings include esthenops and aesthenops. 


\section{Delphinus crotaphiscus Cope, 1865}

Cope's (1865b) rather short description (with no illustrations) states that this species is in the "same groups as styx, euphrosyne, and asthenops" (all known to be striped dolphins). Perrin et al. (1987) confirmed that it was not a spotted dolphin, as had earlier been assumed. It seems likely that this species was indeed a striped dolphin. The type specimen from an unknown locality (formerly at the Museum of Peabody Academy, Salem, and later at the MCZ) has been lost, so it is no longer possible to confirm the species identity. Therefore it might be best that this species be considered a nomen dubium. Variant spellings include crotaphisca.

\section{Tursio dorcides Gray, 1866}

Gray introduced this species in the Additions and Corrections section of his 1866 British Museum catalog (Gray, 1866a). The species was based on a skull in the NHMUK (No. 1861.4.1.7; Table 3) from an unknown locality. Gray said that the skull was "like D. doris." The type specimen is still in the NHMUK, and I recently examined it. The name is considered to be a junior synonym of Stenella coeruleoalba. Variant spellings include dorides and doriedes.

\section{Clymenia euphrosynoides Gray, 1868}

Gray (1868a) proposed this as a replacement name for Delphinus euphrosyne Gray, 1846, which he illustrated in his plate 31 . True (1889) stated that there is a type specimen of this species in the NHMUK (No. 1844.7.19.23), and I recently confirmed this (Table 3). The name is a junior synonym of Stenella coeruleoalba. Variant spellings include euphrosinoides.

\section{Clymenia burmeisteri Malm, 1871}

Malm described this species from a specimen (skull) from Brazil, apparently in the Rijkmuseum, Stockholm. His account is quite detailed and includes measurements and meristics of the skull. The very accurate skull illustrations in Malm's account (plate 6, figs. $54 \mathrm{a}, \mathrm{b})$ show this species to be either a striped dolphin or a Clymene dolphin; however, the condylobasal length reported $(426 \mathrm{~mm})$ is beyond the known range for the Clymene dolphin (see Jefferson, 1996). Therefore, the species name is considered to be a synonym of Stenella coeruleoalba.

\section{Clymenia novae-zealandiae Hector, 1873}

In a short but detailed account that includes measurements, Hector described this species from a specimen from Waikanae, New Zealand. No type specimen is known to be extant. The skull description and illustra- tions (plate 2) in Hector's account associate this species with the striped dolphin. Therefore, the name is a junior synonym of Stenella coeruleoalba. The proper spelling is novaezealandiae.

\section{Delphinus amphitriteus Philippi, 1893}

The species was described from a specimen collected in the South Atlantic Ocean at $29^{\circ} 15^{\prime} \mathrm{S}$. The type description is short, but includes some detail and external measurements. It is unknown if the type specimen still exists. The illustration of external appearance makes it clear that this was a striped dolphin, and the name is a junior synonym of Stenella coeruleoalba.

\section{Stenella clymene (Gray, 1850) - Clymene dolphin \\ Delphinus metis [No. 2] Gray, 1846}

Gray described this species from a specimen (Delphinus metis [No. 2], skull in the NHMUK) from an unknown locality, presumably somewhere in the tropical/ temperate Atlantic Ocean. In the same publication (on the previous page), Gray also described another species of dolphin using the same name (Delphinus metis [No. $1]$ ), which is now considered to belong in the genus Tursiops. Thus, Delphinus metis [No. 2], although being the earliest name used for the Clymene dolphin, can not be a valid name, since it is a junior homonym of Delphinus metis [No. 1]. The complicated taxonomic history of the Clymene dolphin is summarized in Jefferson and Curry (2003).

\section{Delphinus clymene Gray, 1847}

This is the first use of the name clymene for the Clymene dolphin, and the presumed type specimen (skull in the British Museum, NHMUK 350a) was measured by me (Table 3; Fig. 9). However, because no type specimen was originally designated and no description was provided by Gray, this name is technically a nomen nudum and is therefore unavailable for the Clymene dolphin (see Jefferson and Curry, 2003).

\section{Delphinus clymene Gray, 1850}

In this publication, Gray provided a more detailed description of the skull morphology of his Delphinus clymene, including some measurements. No illustrations are given, but Gray explained that this species was the same as his earlier described Delphinus metis [No. 2]. The name clymene could still be made available for use, and since this publication finally provided an available name along with a detailed description and designation of a type, Gray (1850) is the appropriate authority for the valid name of the Clymene dolphin. The type specimen is the same as for Delphinus metis [No. 2] (i.e., 
NHMUK 350a), and is still in the British Museum, where I measured it (Table 3).

\section{Clymene normalis Gray, 1866}

Though it is unclear why Gray (1866a) did not retain the species name clymene when he placed this species in the new genus Clymene, this is simply a renaming of Delphinus clymene Gray, 1850. Therefore the name is a junior synonym of Stenella clymene.

\section{Genus Delphinus Linnaeus, 1758 - common dolphins}

\section{Delphinus delphis Linnaeus, 1758 - common dolphin}

\section{Delphinus delphis Linnaeus, 1758}

Among the three species of "Delphinus" that Linnaeus included in his $10^{\text {th }}$ edition, which is the starting point of modern taxonomy, was this species of common dolphin. Linnaeus based the type description on the information from Oceano Europaeo by Artedi (1738). It was described briefly, with no details or illustration. No type specimen was collected. This is considered the senior synonym and valid name of the common dolphin.

\section{Delphinus vulgaris Lacépède, 1804}

The species is based on a general description that includes an illustration of a whole specimen, which Heyning and Perrin (1994) considered not even referable to genus. Fortunately, there was also a skull illustration and enough details to identify this as a common dolphin (Lacépède's plate 14, fig. 1). Apparently, no type specimen was collected. The published tooth counts are associated with the short-beaked form of Delphinus. Though some might think it best to consider this name a nomen dubium, I consider it to be a junior synonym of Delphinus delphis.

\section{Delphinus capensis Gray, 1828}

The species was based on a specimen collected off the Cape of Good Hope, South Africa. It was a stuffed whole specimen, with the skull inside; the skull was later extracted. The type specimen is in the NHMUK (No. 1841.17.34, whole mount with skull; Table 3) and was measured by me for Jefferson and Van Waerebeek (2002). The illustrations and measurements of the type make it clear that it is a member of the long-beaked population of common dolphins found off the South African coast. The species was resurrected in 1994 by Heyning and Perrin, and until recently, all long-beaked common dolphin populations around the world were thought to be of this species. However, it has been shown recently that the long-beaked condition has arisen independently several times during Delphinus evolution, and this type specimen (although from a long-beaked population) groups genetically with other short-beaked populations around the world (Cunha et al., 2015). Delphinus capensis is no longer recognized as a valid species, and the name is a junior synonym of Delphinus delphis (SMM, 2020). 


\section{Delphinus longirostris G. Cuvier, 1829}

In 1827, J. J. Dussumier collected a specimen of a longbeaked common dolphin from the Malabar coast of India, which Cuvier (1829) described as a new species, Delphinus longirostris. The holotype is in the Muséum National d'Histoire Naturelle (Paris Museum, MNHN A.3065; Table 3). I measured the specimen for Jefferson and Van Waerebeek (2002). However, this name cannot be used for a valid species, since it is preoccupied by Delphinus longirostris Gray, 1828, which is now a synonym of Stenella longirostris (the pantropical spinner dolphin; see Perrin, 1998). Therefore, Delphinus longirostris G. Cuvier is considered a junior synonym of Delphinus delphis, and also a junior homonym of Delphinus longirostris Gray.

\section{Delphinus novae-zelandiae Quoy and Gaimard, 1830}

A dolphin was collected off New Zealand on 4 February 1827 . The type locality was the "eastern coast of New Zealand, near Cape Gable," not far from Tolaga Bay (which is on the central coast of the North Island). The illustration provided by Quoy and Gaimard in their atlas (plate 28) shows a dolphin that could be either a Stenella or Delphinus, but with white patches on the dorsal fin and flippers it appears to be a common dolphin. The type specimen consists of a skull which confirms that this is a common dolphin. External and skull measurements for the type specimen have been published, associating this species with a short-beaked form of Delphinus (Heyning and Perrin, 1994). The current location of the type skull is not known. Variant spellings include zelandae, zeelandae, and zealandiae.

\section{Delphinus loriger Wiegmann, 1840}

Wiegmann published a plate, which represents the first use of this species name (plate 362). However, since there was no description of distinctive features (and no reference to such), it might appear to be not available, but under ICZN Article 12.2.7, the name is available. Heyning and Perrin (1994) discussed the confusion about the date of this species name in their monograph, but were not able to resolve the issue. The holotype specimen (a skull) is in the ZMB, Berlin (No. 66429). See Appendix F for an explanation of the relationship between Wiegmann (1840) and Wagner (1847).

\section{Delphinus zelandae Gray, 1843}

This is simply a renaming of Delphinus novae-zelandiae Quoy and Gaimard. That name is in the synonymy of Delphinus delphis, the common dolphin. Little additional information is given by Gray (1843b), other than to say that the species inhabits "Cooks Straits."

\section{Delphinus janira Gray, 1846}

Gray described and illustrated this species from a Canadian dolphin skull. The type specimen is a skull from Newfoundland, Canada, reportedly originally in the Museum of Bristol (Heyning and Perrin, 1994). The skull is described and illustrated in the type description. True (1889) stated that the type was in the NHMUK (No. 1470a) when he visited in the 1880s, and NHMUK records show it still present in the collection. Low tooth counts associated this species with the short-beaked form of the common dolphin, as does the type locality (only short-beaks are found off eastern Canada). The name is a junior synonym of Delphinus delphis.

\section{Delphinus forsteri Gray, 1846}

Gray based this species on a description and unpublished illustration in Forster (1844). Apparently, no type specimen was collected (Heyning and Perrin, 1994), and the species may have been based on specimens seen swimming at sea. Gray listed them as inhabiting the "Pacific Ocean, between New Caledonia and Norfolk Island." The excellent illustration of external appearance in plate 24 clearly shows what appears to be a short-beaked common dolphin, and the low tooth counts and color pattern further associate it with the short-beaked form. The name is a junior synonym of Delphinus delphis.

\section{Delphinus loriger Wagner, 1847}

The species is based on a description and illustration of a whole specimen from an unknown locality. The type description is short and uninformative. Apparently, no type specimen was retained. Fortunately, there is a plate that shows the external form and color pattern (plate 362), and this clearly indicates a common dolphin (Delphinus sp.). The date associated with this species has been controversial, as the plates showing the illustration by Wiegmann (plate 362 usually listed as Wiegmann, 1840 or 1841) may have been published (and were sometimes bound) separately from the description by Wagner (1847). Heyning and Perrin (1994) considered this species to be a junior synonym of Delphinus delphis, and the illustration confirms this.

\section{Delphinus albimanus Peale, 1849}

This species is based on a specimen reportedly harpooned at the bow of the U.S.S. Peacock ca. 190 miles $(306 \mathrm{~km})$ off the coast of northern Chile $\left(27^{\circ} 16^{\prime} \mathrm{S}\right.$, $75^{\circ} 30^{\prime} \mathrm{W}$ ) during the U.S. Exploring Expedition (Peale, 1849; Cassin, 1858). The illustration of the external shape and coloration of the type (Cassin, 1858, plate 


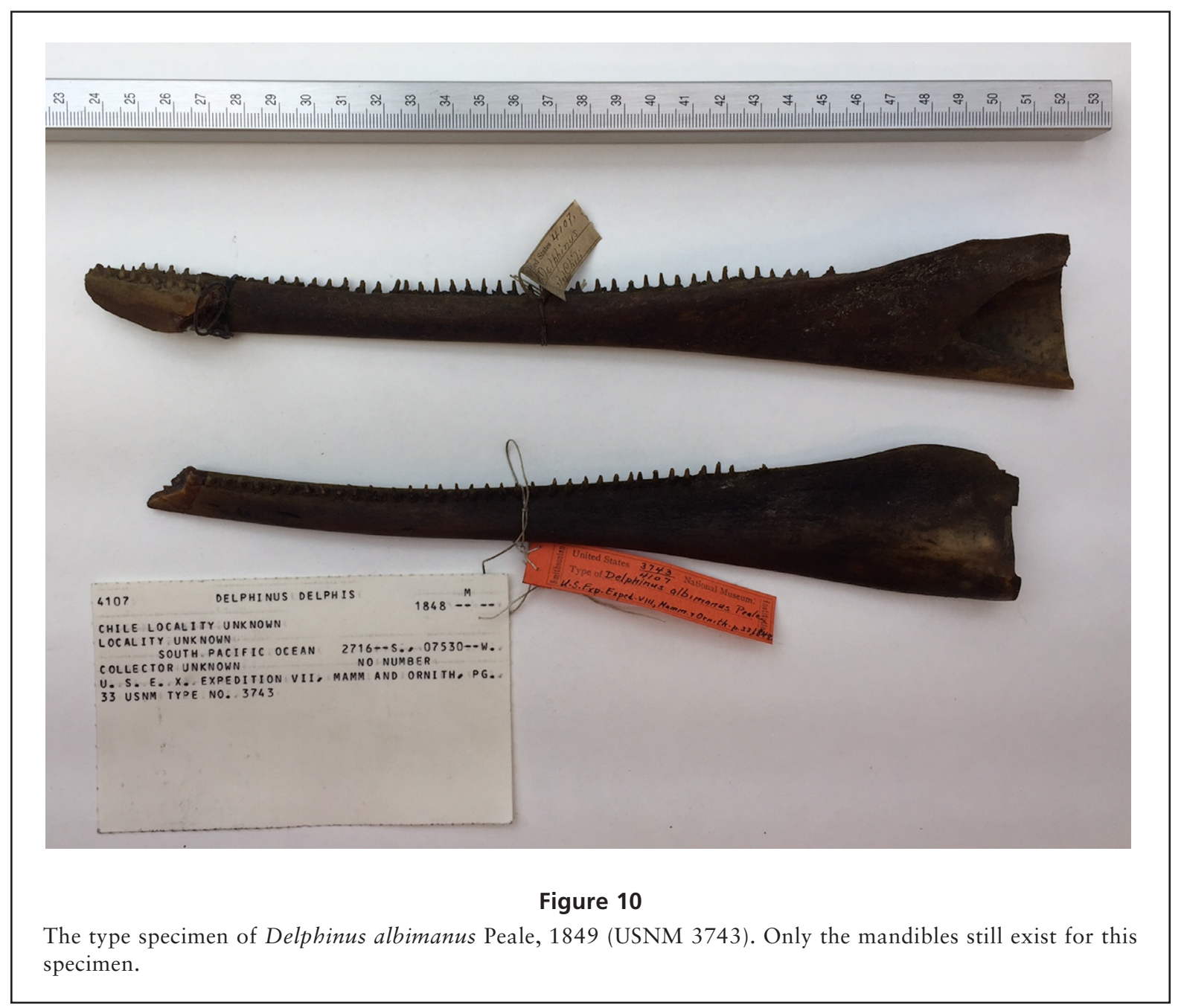

6, fig. 1) make it clear that it is a common dolphin. Though Heyning and Perrin (1994) considered it tentatively to be a short-beaked form, some aspects depicted in the painting do not seem to fit, and it is not clear whether it is of a long- or short-beaked form (Cassin, 1858). The type specimen is in the USNM (Type No. 3743), and True (1889) examined it and removed a portion of the mandible (all that he could find of the skull) from the mounted skin. In 2018, I examined what remains of the type. Unfortunately, only incomplete portions of the mandibles are still in existence (Fig. 10). Other samples (mounted skin) have been lost $\left(\mathrm{Mead}^{6}\right)$. Tooth counts that I took are lower left $=46+3-4$, lower right $=47+3-4$, which are in the range of overlap of long- and short-beaked forms, as currently recognized. See Fisher and Ludwig (2016) for history. The name is currently a synonym of Delphinus delphis.

${ }^{6}$ Mead, J. G. 2019. Personal commun. Natl. Mus. Nat. Hist., Smithson. Inst., Washington, D.C.

\section{Delphinus fulvifasciatus Jacquinot and Pucheran, 1853}

This species is described from a specimen collected from Hobart, Tasmania, Australia. Jacquinot and Pucheran included a short description of supposedly diagnostic features, but the color plate shows only a dolphin of the Stenella/Delphinus group, but which cannot be identified to species. The type specimen, including the stuffed skin and cranium, is in the MNHN (No. CGZ No. 20, CAC A.3025), and Robineau (1990) examined and identified it as a common dolphin, Delphinus delphis. The measurements and tooth counts published by Robineau (1990) refer this specimen to the shortbeaked form, the only one known to occur off southern Australia. Variant spellings include fulvofasciatus.

\section{Delphinus frithii Blyth, 1859}

Blyth's description lacks details, and there are no illustrations. The type specimen was collected at an unspecified locality during a voyage from the United Kingdom to India, so it may be from within the range 
of the Indo-Pacific common dolphin. Published tooth counts of 55/50 prompted Heyning and Perrin (1994) to associate it with a long-beaked form of common dolphin. Sclater (1891) reported that the holotype was in the Calcutta Museum. However, the skull could not be found in either the collection of the Indian $\mathrm{Mu}$ seum (the new name for the Calcutta Museum), nor that of the Zoological Survey of India (where many of the specimens from the old Indian Museum are now housed), when I visited Calcutta in April 2000. If more than one species of Delphinus is eventually recognized, Delphinus frithii might be considered a nomen dubi$u m$, but in the current one-species system, the name is a junior synonym of Delphinus delphis.

\section{Delphinus algeriensis Loche, 1860}

The type description has a reasonable amount of detail, and there is an accurate illustration of the body shape and color pattern. The type specimen is reportedly in the Natural History Museum of Algiers, and consists of a skin with the skull and possibly partial skeleton, presumably from the coast of Algeria (Heyning and Perrin, 1994). Although the illustration shows characteristics that could suggest either Delphinus or Stenella coeruleoalba, the long, prominent grooves on the palate and the color pattern components shown in the illustration indicate Delphinus. Tooth counts associate it with the short-beaked form. The short-beaked form is the only one found in the Mediterranean Sea, adjacent to Algeria, and therefore this name is a junior synonym of Delphinus delphis.

\section{Delphinus moorei Gray, 1866}

The type specimen is a skull from southwest of the Cape of Good Hope, South Africa $\left(34^{\circ} \mathrm{S}, 7^{\circ} 3^{\prime} \mathrm{W}\right)$, reportedly in the Liverpool Free Museum (Walkeri No. 1). Gray's (1866c) account is brief, but does include a crude illustration of external appearance. The palatal grooves are reported to be deep, a diagnostic character of Delphinus sp. Although some measurements are within the range of overlap for both forms of common dolphin, the balance of information suggests that this is associated with the long-beaked form of common dolphin that is very common off the coast of southern Africa (Heyning and Perrin, 1994). The name would therefore be a synonym of Delphinus delphis.

\section{Delphinus walkeri Gray, 1866}

In a slightly longer description than for the previous nominal species, Gray (1866c) introduced this name, and included a rather crude illustration of the external body. The type specimen is reportedly a skull in the Liverpool Free Museum (Walkeri No. 2). The palatal grooves are reported to be deep. The published illustration and measurements do not allow it to be confidently associated with either form of common dolphin, and Heyning and Perrin (1994) considered it to be unidentifiable to either long- or short-beaked. However, based on the reported type locality $\left(35^{\circ} 38^{\prime} \mathrm{S}, 10^{\circ} \mathrm{E}\right.$; in the South Atlantic, ca. $500 \mathrm{~km}$ from the coast of South Africa) and Gray's remark that the skull was very similar to that of Delphinus delphis, I believe this nominal species may be associated with an oceanic short-beaked population of Delphinus delphis.

\section{Delphinus microps Burmeister, 1866}

In a moderate-length account, but with no illustrations, Burmeister described the species based on skulls of three specimens from off the coast of Brazil (Heyning and Perrin, 1994); the syntype specimens (skulls) are reportedly in the MACN-Ma. However, True (1889) stated that there was a type of this species in the NHMUK (No. 349a), and this was confirmed in 2019. But this specimen is the type for Gray's species (see Delphinus microps Gray, 1846). Measurements and tooth counts suggest that this name may be referable to an Atlantic long-beaked form of common dolphin (Heyning and Perrin, 1994). The name is a junior homonym of Delphinus microps Gray (recognized as a spinner dolphin) and is currently considered to be in the synonymy of Delphinus delphis.

\section{Delphinus major Gray, 1866}

Gray (1866a) based his short account on a skull in the British Museum, and the type specimen is still in the NHMUK (No. 1852.10.5.2; Table 3). It is a skull from an unknown locality. The description is brief, with no illustrations, but the skull is said to have wide, but "rather shallow" palatal grooves. Heyning and Perrin (1994) examined the type and collected tooth counts, confirming it as a common dolphin. Measurements provided by Gray (1866a) of the skull, including the rostral length/zygomatic width ratio, and Heyning and Perrin's tooth counts indicate that this specimen may be associated with a relatively long-beaked form of common dolphin (Heyning and Perrin, 1994).

\section{Delphinus pomeegra Owen, 1866}

The type skull was reportedly collected by W. Elliot from the coast of India (Madras), and is in the collection of the Natural History Museum, London (NHMUK 1866.2.5.5). Owen's illustration of the external appearance is not identifiable to species (the color pattern shown is solid black), but the skull illustrations indicate it to be a common dolphin. I examined and measured the type skull in 1999, confirming that 
it is the skull of a long-beaked common dolphin (Table 3 ). The specimen was immature (condylobasal length =ca. $405 \mathrm{~mm}$ ) and the skull is badly damaged, which prompted Heyning and Perrin (1994) to suggest that the name should be considered a nomen dubium. However, the type is identifiable with certainty as an example of the Indo-Pacific common dolphin, and thus I consider this name to be in the synonymy of Delphinus delphis (tropicalis subspecies).

\section{Delphinus bairdii Dall, 1873}

The nominal species Delphinus bairdii was described from two female specimens caught off Point Arguello, California, by whaling captain Charles M. Scammon. The type specimens were prepared and one was reportedly sent to the USNM. It had a place in the register as No. 13802 (True, 1889), but there is no record of this specimen having arrived at the Smithsonian (Fisher and Ludwig, 2016). A neotype specimen has been designated (LACM 84240), and is in the collection of the Los Angeles County Museum of Natural History (Heyning and Perrin, 1994). Measurements were provided by Heyning and Perrin, and I also measured it in 2018 (Table 3). Measurements and tooth counts of the syntypes by Dall, as well as illustrations of one of the specimens from Scammon (1874), clearly associate this species with the long-beaked form found off the California coast (and further south in the eastern Pacific). If that form is eventually found to be a good species, then Delphinus bairdii will be the valid name of that species. It is currently a junior synonym of Delphinus delphis, and the senior synonym of the subspecies Delphinus delphis bairdii (SMM, 2020). Variant spellings include bairdi.

\section{Lagenorhynchus de castelnau Van Beneden, 1873}

Van Beneden described this type of dolphin from a specimen captured off the Cape of Good Hope, South Africa, in November 1856. The description does not contain much detail, but there is a watercolor painting (fig. 2 in Van Beneden's single plate), which clearly shows the general body shape and coloration pattern of a common dolphin (Delphinus), and this species is known to be common off South Africa. The main issue is whether Van Beneden intended his name Lagenorhynchus de castelnau to be a scientific name or a common name. This is somewhat ambiguous, as in the text it is presented in italics, but in the figure caption, only Lagenorhynchus is in italics. True (1889) considered that the name was not intended as a "formal scientific appellation." Whatever Van Beneden's intention was, this name does not strictly conform to binomial structure and does not have a latinized ending, and therefore I do not consider this to be a true scientific name.

\section{E[udelphinus] tasmaniensis Van Beneden and Gervais, 1880}

The species was based on a skull collected from Tasmania, Australia, in 1843 or 1853 . The type specimen is reportedly in the MNHN, but Robineau (1990) reported that the mandible has the number A.3071 and the cranium could not be found (True [1889] was able to examine and measure the cranium). No type description was provided, though there is an illustration of the palate and pterygoid region in Van Beneden and Gervais (1880), clearly showing the very deep palatal grooves and narrow rostrum diagnostic of Delphinus. Only short-beaked common dolphins are known from Tasmania. Heyning and Perrin (1994) suggested that the name should be considered a nomen dubium, but I consider the name to be a junior synonym of Delphinus delphis.

\section{Delphinus dussumieri Blanford, 1891}

This is a new name proposed by Blanford for Delphinus longirostris G. Cuvier, 1829, which was found to be preoccupied. No type specimen was collected. However, this name also can't be used, as it is preoccupied by Delphinus dussumieri Fischer, 1829, which is considered to be a junior synonym of Cephalorhynchus heavisidii (Gray, 1828; Hershkovitz, 1966). Blanford's name is considered to be a junior synonym of Delphinus delphis (van Bree, 1971b,c). Available tooth counts and measurements do not allow it to be confidently referred to any specific form of common dolphin, although only the long-beaked tropicalis subspecies is known from the tropical Indian Ocean (see below).

\section{Delphinus tropicalis van Bree, 1971}

Van Bree (1971c) proposed this new name for the extremely long-beaked Indo-Pacific common dolphin, when he found that both Delphinus longirostris $\mathrm{G}$. $\mathrm{Cu}-$ vier, 1829 and Delphinus dussumieri Blanford, 1891 were preoccupied. Delphinus tropicalis has been used since 1971 to refer to the Indo-Pacific common dolphin by authors who considered it to be a valid species (e.g., Pilleri and Gihr, 1972a,b; van Bree and Gallagher, 1978). However, based on the analyses of Jefferson and Van Waerebeek (2002), this form is now recognized as a subspecies of Delphinus delphis (Delphinus delphis tropicalis) (SMM, 2020). The holotype specimen is the same as for Delphinus longirostris G. Cuvier, 1829 (MNHN A-3065). 


\section{Genus Lagenodelphis Fraser, 1956 - Fraser's dolphins}

\section{Lagenodelphis hosei Fraser, 1956 - Fraser's dolphin}

\section{Lagenodelphis hosei Fraser, 1956}

This species was described by Fraser from a skull and skeleton found by Ernest Hose at the mouth of the Lutong River, Baram, Borneo, Indonesia. The skull and skeleton were described in detail, and Fraser also included photos of osteological characters. However, for 17 years the external appearance was completely unknown, until the species was "rediscovered" in the early 1970s from the collection of several whole specimens from different parts of the tropical ocean, and its external morphology and coloration were described for the first time (Perrin et al., 1973). The type specimen is still in the NHMUK (No. 1895.5.9.1; Table 3) in London. No other species have been described in the genus, and this name is the valid name of Fraser's dolphin.

\section{Genus Lagenorhynchus Gray, 1846 - white- sided and white-beaked dolphins}

\section{Lagenorhynchus albirostris (Gray, 1846) - white- beaked dolphin}

\section{Lagenorhynchus albirostris Gray, 1846}

Gray described and named this species in his 1846 report on the cetaceans of the voyage of the H.M.S. Erebus and Terror. It is based on the type specimen of Brightwell's (1846) Delphinus tursio (a case of mistaken identity that I do not consider to be a new name), which was pre-occupied by Delphinus tursio Gunnerus, 1768 (a synonym of Tursiops truncatus). Gray included good illustrations of the external appearance (plate 10) and skull (plate 11). The origin of the type is from England (stated as the coast of Norfolk and later clarified as Yarmouth; Gray, 1850), and the specimen was in the Norwich Museum in the 1880s (True, 1889), sometimes said to be in the NHMUK (though it was not located upon my visit in 2019). This is the senior synonym and valid name for the white-beaked dolphin.

\section{Delphinus pseudotursio Reichenbach, 1846}

This species was introduced without a description of diagnostic characters, but only from a drawing of its external appearance. The painting (referencing Brightwell's specimen) is presented in Reichenbach's plate 24 , fig. 76 , with no relevant description in the text. No type specimen is known to exist, although Reichenbach apparently intended Brightwell's specimen to be considered the type - see Galatius and
Kinze (2016) for history. Although some might view it as a nomen nudum, the name is available. Because no specific date can be determined for Reichenbach's name, it is considered a junior synonym of Lagenorhynchus albirostris.

\section{Delphinus ibsenii Eschricht, 1846}

Eschricht described this species in a short account from a specimen from Denmark (apparently Agger Tange; see Galatius and Kinze, 2016), but with few details and no illustrations. His intention to publish a more detailed description was never realized. Fortunately, the holotype, the complete skeleton of a dolphin stranded around 1845, is still housed in the NHMD in Copenhagen (No. 4324); see Kinze (2011) for details and a photograph of the type. Apparently Eschricht's name was preceded by Gray's Lagenorhynchus albirostris by eight months, making Delphinus ibsenii a junior synonym of Lagenorhynchus albirostris (see Kinze, 2011). Variant spellings include ibseni.

\section{Lagenorhynchus acutus (Gray, 1828) - Atlantic white-sided dolphin}

\section{Delphinus (Grampus) acutus Gray, 1828}

This species was described in a very short section (with no illustrations), from a skull obtained from the Orkney Islands, originally in the Museum of D. Brookes (Brookes, 1828), but obtained by C. J. Temminck for the Leiden Museum in 1828, and now housed in the RMNH (No. 18281). In 1846, Gray described the species more thoroughly, and stated that the species was very much like Delphinus leucopleurus Rasch, 1843. This is the senior synonym and valid name of the Atlantic white-sided dolphin. Variant spellings include acuta.

\section{Delphinus eschrichtii Schlegel, 1841}

Delphinus eschrichtii was named by Schlegel (1841b), with a type locality in the Faroe Islands. The holotype specimen, a skeleton that had been obtained from Copenhagen in 1838, is in the RMNH (No. 31210). The type description contains a great amount of detail. Useful illustrations of the skull are presented in plates 1 and 2 of the type description. This name is a junior synonym of Lagenorhynchus acutus.

\section{Delphinus leucopleurus Rasch, 1843}

Rasch named this species from specimens collected in the Gulf of Christiana, Norway (previously known as Drøbak, Oslo Fjord). The syntype specimens (a skeleton, skin, and mounted skull) were obtained from a school of 23 animals driven ashore in $1842\left(\right.$ Smeenk $\left.^{7}\right)$.

\footnotetext{
${ }^{7}$ Smeenk, C. 2018. Personal commun. Deceased 2018.
} 
The syntype specimens were in the Christiana Museum, but now are housed in the Leiden Museum (RMNH 31209, 31211) and the Natural History Museum, University of Oslo (NHMO 2645; Wiig and Bachmann, 2013). See Kinze (2011) for history. This name is a junior synonym of Lagenorhynchus acutus.

\section{Leucopleurus arcticus Gray, 1868}

Gray (1868a) used this name as a replacement name for Lagenorhynchus leucopleurus Gray, 1846 (= Delphinus leucopleurus Rasch). His very short account includes plates showing the external appearance of a fetus and several views of the skull. These are clearly Atlantic white-sided dolphins. This name is a junior synonym of Lagenorhynchus acutus.

\section{Lagenorhynchus perspicillatus Cope, 1876}

This was a species described in a detailed account (with measurements) and based on types collected off Portland, Maine. There is a good illustration of the external appearance in plate 4. True (1889) later clarified that the type locality was actually Cape Cod or Woods Hole, Massachussetts (see Vollmer et al., 2019). The lectotype specimen is in the USNM (No. 14244). The name is a junior synonym of Lagenorhynchus acutus.

\section{Lagenorhynchus gubernator Cope, 1876}

Cope described this species from a specimen collected near Portland, Maine. The species description contains moderate detail, and the illustration that is apparently erroneously cited for gubernator (plate 4) is actually of Lagenorhynchus perspicillatus (an Atlantic white-sided dolphin). No holotype is known to exist, but there is a cast of the type at the USNM (No. 12306). The name is a synonym of Lagenorhynchus acutus.

\section{L[agenorhynchus] bombifrons Cope, 1876}

This name is considered to represent a nomen nudum, as it was mentioned in the account on Lagenorhynchus gubernator, but with no description or illustration. This nominal species was compared to Lagenorhynchus gubernator Cope (see above). The name has sometimes been regarded as a synonym of Lagenorhynchus acutus, but by ICZN rules, the name bombifrons as a nomen nudum is unavailable.

\section{Lagenorhynchus cruciger (Quoy and Gaimard, 1824) - hourglass dolphin}

\section{Delphinus cruciger Quoy and Gaimard, 1824}

Based on a description of animals observed at sea between New Holland, Australia, and Cape Horn, Chile, in January 1820, a fairly detailed description and draw- ings are provided (the drawing is not very accurate, but shows a distinctly-colored black and white dolphin). No specimen was collected. A specimen was later collected by d'Orbigny and Gervais (1847), which was deposited in the MNHN (No. CAC: A.3045/1880-647). Robineau (1990) includes a dorsal photo of the cranium. However, see the complicated history of this specimen in Vollmer et al. (2019). This is the senior synonym and valid name of the hourglass dolphin (Lagenorhynchus cruciger). Variant spellings include crucigera.

\section{Delphinus albigena Quoy and Gaimard, 1824}

This species was based on a sighting a few days later than that describing Delphinus cruciger (see above), and therefore likely in the same general area. No type specimen was collected, and Quoy and Gaimard (1824) thought that this was a different species or a younger form of Delphinus cruciger. The animals were probably not seen very clearly, and the illustrations of external appearance do not show an hourglass pattern very well, but they do indicate a small cetacean with a distinct black and white lobed pattern. The name is considered a junior synonym of Lagenorhynchus cruciger.

Delphinus bivittatus Lesson in Lesson and Garnot, 1827

Lesson described this species from an at-sea sighting around Cape Horn, about 140 leagues $(778 \mathrm{~km})$ from the Falkland Islands. No specimen was collected. The description and illustration (plate 9, fig. 3) in the accompaying atlas, although not very accurate, indicate a black-backed dolphin with a white hourglass-like pattern, and make it clear that these were hourglass dolphins. They were thought to be distinct from Delphinus cruciger, because of perceived coloration differences. The name is a junior synonym of Lagenorhynchus cruciger. Delphinus livitatus F. Cuvier, 1836 is simply a mis-spelling (lapsus) of Delphinus bivittatus. Variant spellings include livitatus and livittatus.

\section{Phocaena homeii Smith, 1829}

Smith based this species on a black and white dolphin found around the Cape of Good Hope, and which he said was often caught in Table Bay (Cape Town). His account of it is short and only includes details on the external appearance. Apparently, there is a type specimen in the SAM (unconfirmed). The name is considered a junior synonym of Lagenorhynchus cruciger.

\section{Lagenorhynchus clanculus Gray, 1846}

This species was named by Gray, who provided good illustrations of the skull, but with no accompanying description in the text. Fraser and Noble (1968) identi- 
fied the skull as being an example of Lagenorhynchus cruciger, and the name is now considered a junior synonym of that species. No type locality was specified for the type skull, which is still in the NHMUK (No. 1849.5.25.3; Table 3; see Vollmer et al., 2019). Gray (1850) later noted that the type skull was from the Pacific Ocean. Variant spellings include clancula.

\section{Delphinus obscurus Gray, 1850}

Gray used this name (not Delphinus obscurus Gray, 1828) as a replacment name for a group of dolphin species that he synonymized (including Delphinua cruciger Quoy and Gaimard, 1824; Delphinus bivittatus Lesson in Lesson and Garnot, 1827; and Delphinus albigena Quoy and Gaimard, 1824). He identified a skull (though not specifically designated as a holotype) at the MNHN, and this appears to be MNHN 1880-646 (Robineau, 1990). This name was considered a junior synonym of Lagenorhynchus cruciger by Vollmer et al. (2019); however, it is also a junior homonym of Gray's 1828 name, and therefore cannot be valid.

\section{Electra clancula Gray, 1868}

Gray (1868a) introduced this name as a renaming of his Lagenorbynchus clanculus Gray, 1846. The name is known to be a junior synonym of Lagenorhynchus cruciger, and also the senior homonym of Electra clancula Hector, 1873.

\section{Lagenorhynchus latifrons True, 1889}

True used this name in discussing a species based on a skull from New Zealand in the Paris Museum (MNHN a3041), which had this species name listed on the label. No more specific type locality is given, and there is no description of identifying features, and no figures presented. True did state that he could not find a description of the species in the literature, and he does give a few measurements of the type. Vollmer et al. (2019) regarded the name as a junior synonym of Lagenorhynchus cruciger, but in keeping with the ICZN rules (since there was no description of characters that were purported to distinguish it), the name should be viewed as a nomen nudum, and therefore unavailable.

\section{Phocaena d'orbignyi Philippi, 1893}

This is a replacement name for Delphinus cruciger d'Orbigny and Gervais, 1847, as Philippi thought that this was a different species. No type specimen was collected. Philippi's account contains a moderate level of detail, and the illustration of external appearance (plate 2, fig. 2) is a stylized, but clearly identifiable, hourglass dolphin. The name is now considered a junior synonym of Lagenorhynchus cruciger.

\section{Lagenorhynchus wilsoni Lillie, 1915}

Lillie based this species on animals observed swimming at sea from the vessel Discovery, and earlier described, but not named, by Wilson (1907). Lillie included nine sighting records of the species in his account. Wilson's observations took place between 1901 and 1904, in the Southern Ocean between $54^{\circ}$ and $65^{\circ} \mathrm{S}$ (just north of the pack ice). No specimens were collected. Lillie does not include any figures, though he refers to fig. 7 of Wilson (1907), which clearly shows hourglass dolphins. The name is now considered a junior synonym of Lagenorhynchus cruciger.

\section{Lagenorhynchus obscurus (Gray, 1828) - dusky dolphin}

\section{Delphinus (Grampus) obscurus Gray, 1828}

This species was introduced from several specimens collected off the Cape of Good Hope, South Africa. Gray's short account includes a useful illustration of external appearance. The type specimens (an adult and young) were stuffed skins, with the skulls inside. The skull of the adult has been extracted, and is now recognized as the lectotype specimen. It was originally in the Museum of the Royal College of Surgeons, but is now in the NHMUK (No. 1841.1733; Table 3). This name is the senior synonym and valid name of the dusky dolphin. Variant spellings include obscura and obscurum.

\section{Delphinus fitzroyi Waterhouse, 1838}

Waterhouse (1838a,b) described a dolphin specimen harpooned in the Bay of St. Joseph, Patagonia, Argentina $\left(42^{\circ} 30^{\prime} \mathrm{S}\right)$, apparently collected and examined by Charles Darwin on the voyage of the H.M.S. Beagle, as a distinct species. External measurements are included in the description, which are also repeated in the official report of the voyage (Waterhouse, 1838b). The illustration in both accounts shows this to be a dusky dolphin, and the name is now considered to be a junior synonym of Lagenorbynchus obscurus, and the senior synonym of the subspecies Lagenorhynchus obscurus fitzroyi (SMM, 2020). The type specimen (rostrum and anterior part of the mandibles only - Fig. 11) is housed in the NHMUK (1939.2.18.1; Table 3). Variant spellings include fitzroy.

\section{Delphinus breviceps Wiegmann, 1840}

Wiegmann published a plate (plate 368), which represents the first use of this species name. The painting is very similar to that published later in Jacquinot and Pucheran (1853), and resembles a dusky dolphin, though not very accurately. Despite the fact that there was no description of distinctive features (and no reference to such), the name is available under ICZN rules 


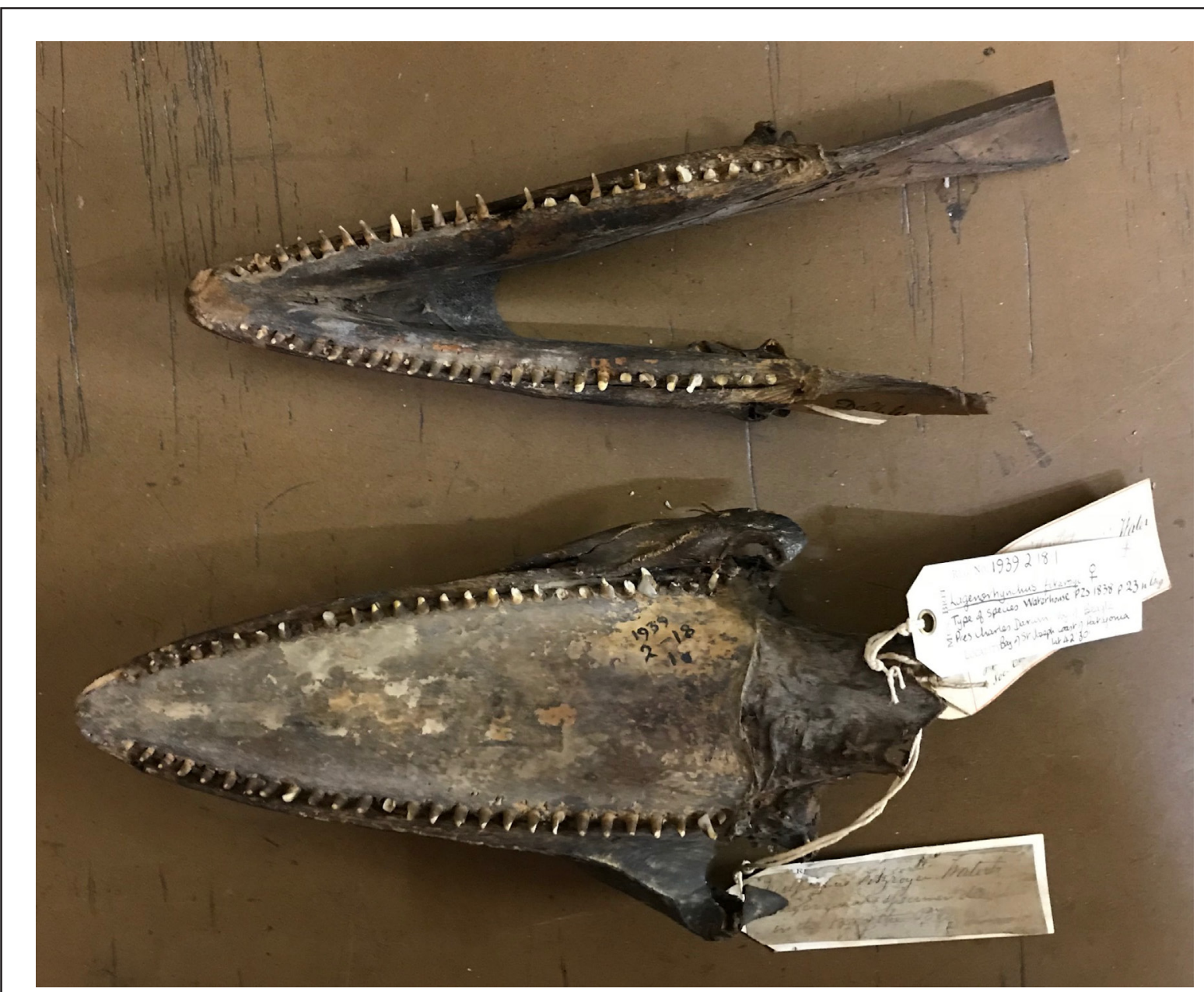

Figure 11

The type specimen of Delphinus fitzroyi Waterhouse, 1838 (NHMUK 1939.2.18.1). This specimen consists of only the anterior portions of the rostrum and mandibles, and was collected by Charles Darwin on the voyage of H.M.S. Beagle.

and is considered a junior synonym of Lagenorhynchus obscurus.

\section{Delphinus breviceps Jacquinot and Pucheran, 1853}

Although sometimes erroneously credited to Wagner (1847), Jacquinot and Pucheran provided a very short description of this species, but their account included an illustration of the external form (not highly accurate) and good views of the skull, which allow it to be identified as a dusky dolphin. The holotype of this nominal species was obtained from Rio de la Plata, Argentina (about 20 leagues [111 km] from the mouth of the river). The type specimen is apparently still in the MNHN (JAC:1880-646). Robineau (1990) provides a photo and some measurements of the holotype skull. The name is listed in the appendix of Wagner (1847), referring to Wiegmann's (1840) plates, but with no description. The name is considered to be a junior synonym of Lagenorhynchus obscurus. See Vollmer et al. (2019) for a summary of the history of this species and its type specimen.

\section{Clymene similis Gray, 1868}

In a somewhat-detailed (for Gray) description, Gray (1868b) described this as a new species, from a holotype specimen (skull), which is in the NHMUK (No. 1509b; Table 3). The type was collected from off the Cape of Good Hope, South Africa, and Gray listed features of the skull that he thought differentiated it from Lagenorhynchus obscurus. He did not illustrate the whole skull, but only the pterygoid region. Despite some past uncertainty about the identity, the name is 
considered to be a junior synonym of Lagenorhynchus obscurus.

\section{Prodelphinus petersii Reinhardt in Lütken, 1889}

Reinhardt described this species from a holotype specimen collected from near Amsterdam Island, in the southern Indian Ocean $\left(37^{\circ} 55^{\prime} \mathrm{S}, 77^{\circ} 40^{\prime} \mathrm{E}\right)$. The description is not very long, but does include a small illustration of the skull. The type is still in the collection of the Zoological Museum, Copenhagen (NHMD 4325). It was recently examined by Van Waerebeek et al. (1995), and was confirmed to be a specimen of Lagenorhynchus obscurus, and so the name is a junior synonym of that species.

\section{Phocaena posidonia Philippi, 1893}

Based on a specimen harpooned off Chile $\left(48^{\circ} 10^{\prime} \mathrm{S}\right.$, $\left.77^{\circ} \mathrm{W}\right)$, Philippi described this species in 1893 . His description includes measurements and information on external appearance, and there is an illustration of the body shape and coloration (plate 2, fig. 1), which shows this to be a dusky dolphin. The holotype specimen (a skin and skull) apparently still exists at the Natural History Museum, Santiago (NMH-S). This name is considered a junior synonym of Lagenorhynchus obscurus, and the senior synonym of the subspecies Lagenorhynchus obscurus posidonia (SMM, 2020).

\section{Tursio? panope Philippi, 1895}

In a very brief account with no illustrations, Philippi (1895, 1896) described Tursio panope from a skull from Chile at the NHM, Santiago (No. 584). There has long been controversy about its true identity. The type was examined by K. S. Norris, and by R. N. P. Goodall and I. S. Cameron, and it has generally been considered to be a junior synonym of Cephalorhynchus eutropia. However, due to dubious characters, Goodall et al. (1988a) suggested that it should be considered a nomen dubium. Later, Pichler and Olavarria (2001) conducted genetic analyses that suggested it was synonymous with Cephalorhynchus eutropia. However, there may have been some mix-up of samples, due to loose teeth. Based on thorough assessments, the identification was confirmed as Lagenorhynchus obscurus by Brownell and Mead (1989) and Canto (2014), and Tursio panope therefore belongs in the synonymy of that species.

\section{[Lagenorhynchus] thicolea Trouessart, 1899}

This has been considered to be a renaming/new name combination, synonymizing Delphinus breviceps Jac- quinot and Pucheran, 1853 with Lagenorhynchus thicolea Gray, 1846 and other names (see Vollmer et al., 2019 for a full explanation). They considered the name to be a junior synonym of Lagenorhynchus obscurus. However, Trouessart's intention was not fully clear, and based on the way he listed the name I think that he used Lagenorbynchus thicolea simply in reference to Gray's species (which is a junior synonym of Lissodelphis borealis - see below). Thus Trouessart's name would not be a new species name.

\section{Lagenorhynchus australis (Peale, 1849) - Peale's dolphin}

\section{Phocoena australis Peale, 1849}

This species was based on a brief description by Peale of a specimen harpooned in the South Atlantic Ocean off the coast of Patagonia during the U.S. Exploring Expedition of 1838-1842 (note that Peale's volume was later withdrawn, due to a belief that it contained too many taxonomic errors - see p. 343 in Philbrick, 2003). In the later re-issued version of this volume (Cassin, 1858), virtually the same description appears under the name Delphinus obscurus. Peale refers to a plate of external appearance (plate 6, fig. 2) of his Phocoena australis, but that particular volume of plates apparently never was published (a common issue with the "Ex Ex" reports - see Philbrick, 2003). A plate volume did accompany Cassin's (1858) reissue, and I believe that plate 5, fig. 1 of that volume corresponds to the animal that Peale originally named Phocoena australis (although it is labeled as Delphinus obscurus in that volume). The painting is realistic, and the specimen is undoubtedly a Peale's dolphin. There is some evidence that the type collection locality can be more specifically given as between Staten Island and Cape San Diego, in Tierra del Fuego (Argentina), though this information is not provided in the original type description (see Kellogg, 1941). The type specimen was likely originally intended to be archived in the USNM, but now appears to have been lost. This name is the senior synonym and valid name of Peale's dolphin.

\section{Delphinus obscurus (in part) Cassin, 1858}

This is a replacement name for Phocoena australis. Cassin primarily used Peale's description, and synonymized Phocoena australis with Delphinus obscurus (= Lagenorhynchus obscurus). The painting he provides (plate 5, fig. 1) very clearly shows a Peale's dolphin, and therefore this name can be considered a junior synonym of Lagenorhynchus australis. However, the name is also a junior homonym of Delphinus obscu- 
rus Gray, and therefore cannot be valid. The type may still be at the USNM, but this needs to be confirmed.

\section{Sagmatias amblodon Cope, 1866}

The type specimen is a skull in the USNM (No. 3887), collected at sea on the U.S. Exploring Expedition in 1839, of which Cope (1866) provided a description and measurements. His description is moderately detailed, but there are no figures. Cope also specified no type locality, but Kellogg (1941) stated that the type was collected between Staten Island and Cape San Diego, Tierra del Fuego, which suggests that the type may have been the same as that for Phocoena australis, though this is uncertain (see Goodall et al., 1997). Kellogg also provides, for the first time, a detailed description of the species that includes measurements, photos of the skull and external appearance, and comparisons to other, related species. The name is considered to be a junior synonym of Lagenorhynchus australis. See Vollmer et al. (2019) for more detailed historical information.

\section{Tursio chiloensis Philippi, 1900}

In a moderately-detailed section, Philippi described this species based on an incomplete skull collected near Ancud, on Chiloe Island, Chile. He provided more information in a follow-up paper (Philippi, 1901). The type is apparently still maintained at the NHM, Santiago (MNHN-S 586). Although the illustration provided in the type description shows what would appear to be the underside of the rostrum of a phocoenid, the name was actually determined to be a junior synonym of Lagenorhynchus australis by Goodall (1986). I provisionally follow her recommendation.

\section{Lagenorhynchus obliquidens Gill, 1865 - Pacific white-sided dolphin}

\section{Lagenorhynchus obliquidens Gill, 1865}

The Pacific white-sided dolphin was described by Gill from three skulls (syntypes) collected at San Francisco, California, and which are still located at the USNM (Nos. 1961, 1962, 1963). The short type description did not include any illustrations, but the species was described in much more detail and illustrated in Scammon's (1874) classic book, The Marine Mammals of the Northwestern Coast of North America. This is the senior synonym and valid name of the Pacific whitesided dolphin.

\section{Delphinus longidens Cope, 1866}

Cope described this nominal species of dolphin from a type specimen (skull), which is still in the USNM (No. 3886). The account is brief, and contains no illustra- tions. The type locality is not precisely known, but it presumably came from somewhere in the North Pacific. The name is a junior synonym of Lagenorhynchus obliquidens.

\section{Lagenorhynchus ognevi Sleptsov, 1955}

This new species was described in a detailed account (with multiple illustrations and measurements) of four syntype specimens (three complete skeletons with skulls, and one skull) from the western Pacific Ocean (in the Nemoro Sea, 15-20 miles east of the South Kuril Cape, Kunashir Island, Russia). The syntypes are reportedly in the Zoological Museum of Moscow State University, although Perrin et al. (2004) listed only a single skull of this species in the collection (ZMMGU S-60152); it is unknown if this specimen is one of the syntypes. Although a number of differences were proposed, these animals are now considered conspecific with the Pacific white-sided dolphin of the central and eastern North Pacific (Lagenorhynchus obliquidens), and therefore this name is a junior synonym of that species.

\section{Genus Lissodelphis Gloger, 1841 - right whale dolphins}

\section{Lissodelphis peronii (Lacépède, 1804) - southern right whale dolphin}

\section{Delphinus peronii Lacépède, 1804}

Francois Peron observed black and white dolphins of an unknown species on the expedition of Baudin to Australia, and sent his notes to the Paris Museum (MNHN). Based on those notes, this species was described by Lacépède from a specimen collected south of Van Diemen's Land (Tasmania) in 1802, and may be represented by a skull in the Paris Museum (needs to be confirmed). A plate (Gray, 1846) showing the external appearance makes it clear that this is a southern right whale dolphin, and this name is therefore the senior synonym and valid name of that species. Variant spellings include peroni.

\section{Delphinus leucorhamphus Peron in Lacépède, 1804}

According to Newcomer et al. (1996), Lacépède changed Peron's name leucorhamphus to peronii, when describing this species. The description was apparently based on specimens observed at sea south of Tasmania on a French expedition to the Antarctic. No type was designated, but an unpublished manuscript by the collector, J. J. Dussumier (MNHN manuscript No. 894 - Arvy, 1972b), shows an outline of a specimen he obtained, which clearly shows it to be a southern right 


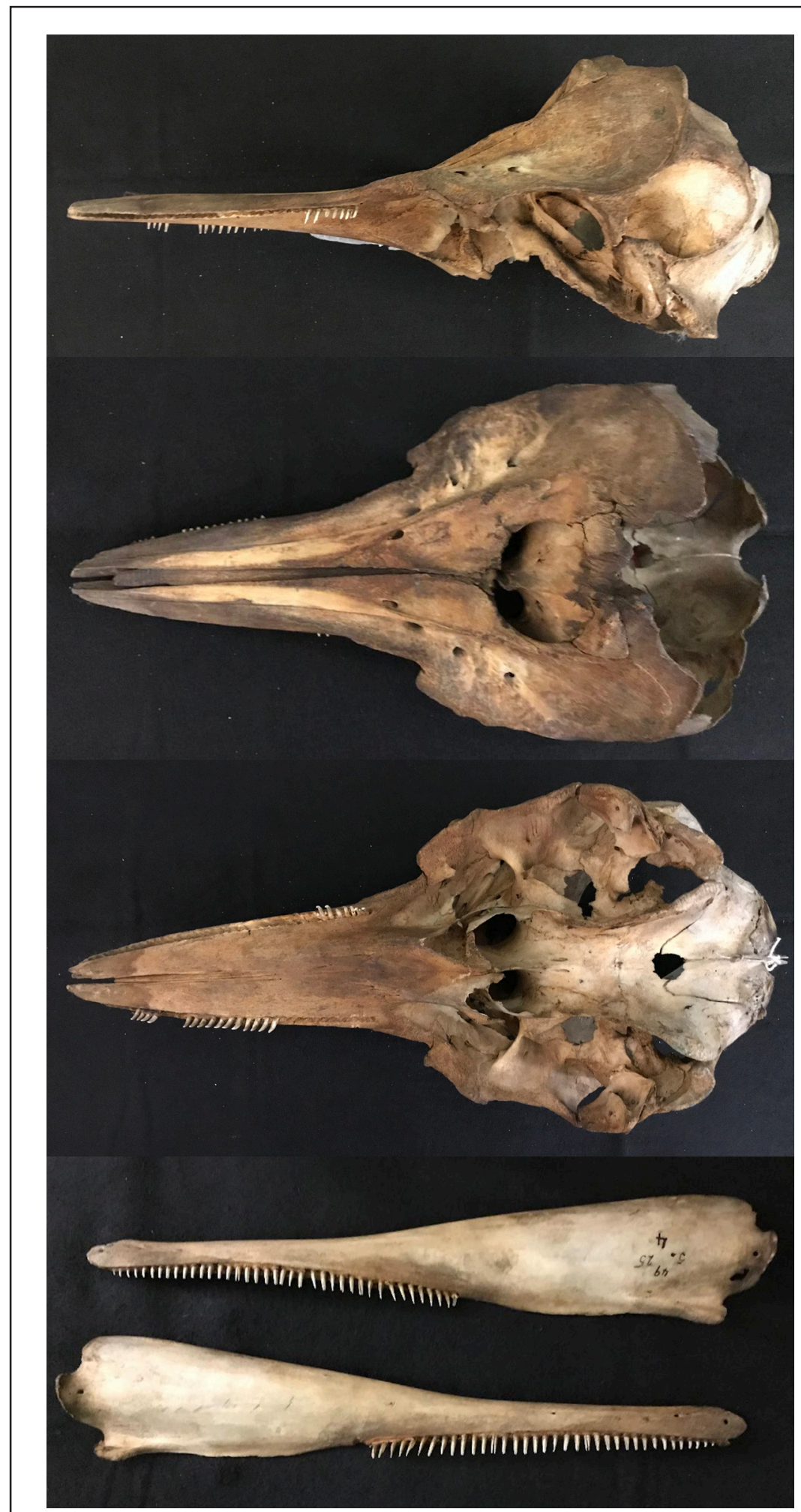

Figure 12

The type specimen of Lagenorhynchus thicolea Gray, 1846 (NHMUK 1849.5.25.4). This specimen is known to be of the genus Lissodelphis. Based on its reported collection locality (off the west coast of North America), it would be Lissodelphis borealis, but some uncertainty remains about which species of Lissodelphis it represents. 
whale dolphin. Variant spellings include leucoramphus and leucorrhamphus.

\section{D[elphinus] bicolor Gray, 1846}

Gray listed this species as a synonym of Delphinapterus (=Delphinus) peronii, crediting "Stephenson MSS Icon. ined." The type locality is apparently from the South Pacific, reportedly at $46^{\circ} 48^{\prime} \mathrm{S}, 142^{\circ} \mathrm{W}$. The plate (plate 15 in Gray, 1846) showing the external appearance of Delphinus peronii makes it clear that this is a southern right whale dolphin, and Delphinus bicolor should therefore be considered a junior synonym of that species. Although there was no description of identifying characters, by ICZN rules, the presence of an "indication" (the illustration in the plate) dictates that the name could still be considered available.

\section{Delphinapterus lessonii Philippi, 1893}

This was a new name proposed for Delphinus peronii of Lesson and Garnot (1827), according to Newcomer et al. (1996). No type specimen was designated. Philippi's plate of external appearance (plate 4, fig. 3 ) shows a southern right whale dolphin. The name is a junior synonym of Lissodelphis peronii.

\section{Prodelphinus gervaisi Trouessart, 1899}

This is a new name based on Prodelphinus leucorhampus of Van Beneden and Gervais (1880), according to Newcomer et al. (1996). The name is thus considered to be a junior synonym of Lissodelphis peronii.

\section{Lissodelphis borealis (Peale, 1849) - northern right whale dolphin}

\section{Lagenorhynchus thicolea Gray, 1846}

This species was based upon a skull illustrated (but not described in the text) in plate 36 of Gray (1846). The type skull is in the NHMUK (1849.5.25.4; Table 3, Fig. 12). The illustration shows the skull of a right whale dolphin (genus Lissodelphis), but it could be either species, and the lack of designated type locality did not allow it to be identified to species based on known distribution. However, in a later publication, Gray (1849) stated that the specimen was collected in the North Pacific Ocean ("West Coast of America"), thus suggesting that this name should be an example of the northern right whale dolphin. Both tags (old and new) on the skull also indicate "N. America," and if this is correct, it has serious implications for the nomenclature of the northern right whale dolphin. As this name predates Peale's (1849) Delphinapterus borealis (see next paragraph), thicolea would technically be the valid name of that spe- cies. However, this would upset longstanding usage, since the name thicolea has not been used for this species in over a century (past use of the name erroneously considered it to be a species of the genus Lagenorhynchus or possibly Lissodelphis peronii see for example Rice and Scheffer, 1968; Rice, 1977; Vollmer et al., 2019). There is an even more pressing issue, though. Doubts have been raised about this being a northern right whale dolphin, as the collector, "Dr. Dickie," was known to have collected cetacean specimens in the Southern Hemisphere, but not in the North Pacific where the northern right whale dolphin is exclusively found (see Vollmer et al., 2019). Therefore, some have opted that Lagenorhynchus thicolea should be considered to be a nomen dubium. However, I believe that unless specific information can be found indicating that the North Pacific collection locality is incorrect, the information on the tags and in the published literature must be trusted, associating this species with the northern right whale dolphin. A proposal to designate this name as a nomen oblitum has been made (Jefferson, 2021). Trouessart's (1899) use of this name appears to be in reference to Gray's species, and thus is not a new species name (as has sometimes been assumed).

\section{Delphinapterus borealis Peale, 1849}

Peale described this species from a specimen collected at $46^{\circ} 06^{\prime} 50^{\prime \prime} \mathrm{N}, 134^{\circ} 05^{\prime} \mathrm{W}$, about $800 \mathrm{~km}$ off the coast of Astoria, Oregon, during the U.S. Exploring Expedition of 1838-1842 (note that Peale's volume was later withdrawn, due to a belief that it contained too many taxonomic errors - see p. 343 in Philbrick, 2003). In the later re-issued version of this volume (Cassin, 1858), virtually the same description appears under the name Delphinus borealis. The plate that Peale referred to (plate 8, fig. 2) was not published as such, but did appear in Cassin's (1858) atlas as plate 7, fig. 2, under the name Delphinapterus borealis. Both that plate and the text description clearly indicate a northern right whale dolphin. The specimen on which this species was based was not included in Peale's list of specimens supplied to the USNM, and therefore no holotype specimen is known to exist (Fisher and Ludwig, 2016). This name has traditionally been considered the senior synonym of the northern right whale dolphin, but it is predated by Lagenorhynchus thicolea (see above). However, since the latter name has not been used for the species in over a century, and reverting to it would upset longstanding usage, it is suggested that borealis be retained, and that Delphinapterus borealis be conserved as a nomen protectum and thus the valid name of the northern right whale dolphin. 


\section{Genus Cephalorhynchus Gray, 1846 - piebald dolphins}

\section{Cephalorhynchus commersonii (Lacépède, 1804) \\ - Commerson's dolphin}

\section{Delphinus commersonii Lacépède, 1804}

Lacépède described Commerson's dolphin from an unpublished manuscript by Philibert Commerson on a dolphin sighting at sea during Bougainville's expedition around the world in 1766-1769. The sighting took place around Tierra del Fuego and the Strait of Magellan in 1767. The description mainly talks about the body shape, coloration, and behavior of the dolphins. There was no type specimen collected, but the information presented by Lacépède allies this with what is known today as Commerson's dolphin. This name is the senior synonym and valid name of the Commerson's dolphin. Variant spellings include commersoni.

\section{Lagenorhynchus floweri Moreno, 1892}

Moreno provided a detailed description of this species, which included measurements and excellent illustrations of the skull and external appearance. From two specimens obtained, he was the first to describe the skull of this species, which is without a doubt what we now know as Commerson's dolphin. One of the types from Bahia de Santa Cruz, Argentina, is still in the Museo de la Plata, Argentina (MLP 1480; Olivares et al., 2016), and Brownell and Praderi (1985) "rediscovered" it, publishing photos and comparative measurements. The other type specimen may be lost. The name is now considered to be a junior synonym of Cephalorbynchus commersonii.

\section{L[agenorhynchus] burmeisteri Moreno, 1892}

Moreno used this name as a substitute or replacement for Lagenorhynchus floweri, in the same publication. Apparently this name was his first choice for the new species he described as Lagenorhynchus floweri, and Goodall et al. (1988b) considered Lagenorhynchus burmeisteri to be a nomen lapsus for that species (however, this is not a term officially recognized by the ICZN). There is no separate account and no illustration of this species in Moreno's paper. Thus, the name is a junior synonym of Cephalorhynchus commersonii.

\section{Cephalorhynchus heavisidii (Gray, 1828) - Heaviside's dolphin}

\section{Delphinus (Grampus) heavisidii Gray, 1828}

In a short account, this species was described by Gray from a mounted specimen from the Cape of Good
Hope, South Africa, in the Museum of the Royal College of Surgeons (later the NHMUK). The skull of the type specimen collected by Captain Haviside was later removed from the mounted skin; the whereabouts of the skin is not known, but the skull is still in the NHMUK (No. 1841.1732; Table 3). A decent illustration of the whole body (plate 2, fig. 6) shows a Heaviside's dolphin, and this is the senior synonym and valid name of Cephalorhynchus heavisidii. Variant spellings include heavisidei and headivisii.

\section{D[elphinus] capensis Dussumier in G. Cuvier, 1829}

In 1829, G. Cuvier described this species (credited to the collector, J. J. Dussumier); his "marsouin du Cap" was from a specimen collected from near the Cape of Good Hope, South Africa (identified as the "Cap de Bonne-Esperance" by Robineau, 1990). The specimen is known to be still present in the MNHN as a stuffed skin with skull (CGZ No. 26 or A.3063). See detailed description with measurements of the skin in Robineau (1990), who lists it as "Phocaena capensis G. Cuvier, 1829." This is considered to be a Heaviside's dolphin, based on information contained in a rediscovered sketch of the type (in an unpublished manuscript by the collector J. J. Dussumier, MNHN manuscript No. 894 - Arvy, 1972b), as well as the clearly-identifiable stuffed skin (see Best [1988] and Robineau [1990] for detailed history). This name is considered a junior synonym of Cephalorhynchus heavisidii.

\section{Delphinus dussumieri Fischer, 1829}

This was a replacement name for Delphinus capensis, which was found to be pre-occupied. This name is the senior homonym of Delphinus dussumieri Blanford, 1891 (which, in turn, is a junior synonym of the common dolphin [Delphinus delphis]).

\section{Delphinus cephalorhynchus F. Cuvier, 1836}

F. Cuvier used this name for what is thought to be Heaviside's dolphin, apparently as a replacement name for Delphinus capensis Dussumier in G. Cuvier, 1829, a species that G. Cuvier called "marsoiun du Cap" (note that in an alternate, presumably earlier, version of F. Cuvier's book, the name "D. capensis" is used instead of "D. cephalorhynchus"). The type specimen is presumably the same as for Delphinus capensis. This name is considered a junior synonym of Cephalorhynchus heavisidii.

\section{Delphinus hastatus F. Cuvier, 1836}

This species was described by F. Cuvier, from two different descriptions by different people, accompanied by figures. The first, by J. R. C. Quoy, was from a speci- 
men collected near the Cape of Good Hope. No type specimen is thought to exist, and Cuvier did not include a figure of this new species in his monograph. The second is a "rediscovered" painting of this species from an unpublished manuscript (reproduced in Arvy, 1972a, fig. 7; Arvy, 1977, fig. 7; MNHN manuscript No. 109), which shows a quite accurate rendition of a dolphin that is undoubtedly a Heaviside's dolphin. The name is thus a junior synonym of Cephalorhynchus heavisidii.

\section{Delphinus tridens Castelnau in P. J. Van Beneden, 1873}

This nominal species was introduced by Van Beneden, from a specimen originating from South Africa. In his paper, Van Beneden described and figured the type, which is clearly a Heaviside's dolphin, but he did so mistakenly under the name Orca capensis (he probably meant Delphinus capensis G. Cuvier). However, he also introduced for the species the new name Delphinus tridens, which he obtained from an unpublished manuscript by F. Castelnau. The latter name is now considered a junior synonym of Cephalorhynchus heavisidii. No existing type is known.

\section{Orca capensis P. J. Van Beneden, 1873}

See above explanation under Delphinus tridens for the origin of this name. The name, however, is a junior homonym of Orca capensis Gray, 1846 (now a junior synonym of Orcinus orca), and therefore cannot be a valid name.

\section{Cephalorhynchus eutropia (Gray, 1846) - Chilean dolphin}

\section{Delphinus lunatus Lesson, 1826}

This is apparently the earliest description of the Chilean dolphin. It was based on an observation at sea in Bahia de Concepcion, Chile, and the description is quite brief and somewhat generic. No type specimen was collected. Lesson and Garnot (1827) redescribed the species, mentioning a brown crescent behind the blowhole. The associated atlas includes a plate showing the supposed external appearance of this species (plate 4, fig. 4, and reproduced in Goodall et al., 1988a), and this does not look much like a Chilean dolphin. However, the dark crescent is clearly shown, and Goodall et al. (1988a) interpreted this as indicating it to be recognizable as a Chilean dolphin. Since the name has apparently not been used for this species since at least 1858 , it has been considered a nomen oblitum, though without proper justification (Goodall et al., 1988a). A specific proposal to do so, with appropriate documentation according to the current ICZN rules, has been made (Jefferson, 2021).

\section{Delphinus eutropia Gray, 1846}

Gray illustrated, but did not describe in the text, this species, from a skull in the British Museum, collected by Dr. Dickie. The type is still in the NHMUK (No. 1849.5.25.2; Table 3). The illustration of the skull (plate 34, labeled as "Delphinus eutropia") is consistent with the Chilean dolphin (and I confirmed on a visit to the NHMUK in 2019). Although not the earliest name, this name has been in more-or-less continuous use for this species for many decades, and the name is to be considered a nomen protectum and the valid name for the Chilean dolphin. See Goodall et al. (1988a) for history.

\section{Eutropia dickiei Gray, 1866}

Gray (1866b) used this name for what is now considered to be a Chilean dolphin. The name is a replacement name and is now regarded as a junior synonym of Delphinus eutropia. Variant spellings include dickii.

\section{Phocaena (Hyperoodon?) albiventris Perez Canto in Philippi, 1893}

This new species was based on a specimen collected near Valparaiso, Chile, in 1882 (Philippi, 1893; Perez Canto, 1896). The type specimen may still exist at the NMH, Santiago. Perez Canto's description and the somewhat-crude illustrations of the external appearance clearly indicate the Chilean dolphin (see Goodall et al., 1988a). The name is a junior synonym of Cephalorhynchus eutropia.

\section{Tursio? platyrrhinus Philippi, 1895}

This is a species described by Philippi, based on skulls at the NMH, Santiago. His rather detailed account includes measurements and various views of the skull, which appear to be from a Chilean dolphin. This name is now considered to be a junior synonym of Cephalorbynchus eutropia. Variant spellings include platyrhinus.

\section{Cephalorhynchus hectori (P. J. Van Beneden, 1881) - Hector's dolphin}

\section{Electra clancula Hector, 1873}

Hector described a new species of New Zealand dolphin in 1873, the type specimen of which is in the Colonial Museum, Wellington (now Museum of New Zealand Te Papa Tongarewa). He provided illustrations of the skull and external appearance, and in another paper (Hector, 1872) he provided measurements and illustrations. These show that the species he described is what is now known as Hector's dolphin. However, the name cannot be used for Hector's dolphin, as it is a junior homonym 
of Electra clancula Gray, 1868 (Gray, 1868a) (now considered to be in the synonymy of Lagenorhynchus cruciger). Variant spellings include clancula.

\section{Electra hectori P. J. Van Beneden, 1881}

In a detailed species account, P. J. Van Beneden provided a description of the New Zealand endemic dolphin, based on a type specimen (skin and skeleton) at the Louvain Museum, Brussels, or possibly the Museum Royale d'Histoire Naturelle, Brussels. He included several illustrations showing the body and color pattern of this unique dolphin. Although this is not the earliest name used for Hector's dolphin, it is in fact the valid name of the species, since the earlier name was shown to be a junior homonym and therefore cannot be a valid name.

\section{Cephalorhynchus albifrons True, 1889}

True provided a description of what he considered a new nominal species from New Zealand. The illustrations of the skull and external appearance (which are reproduced from Hector, 1872, 1873), combined with the known range in New Zealand, make it clear that this is what we now know as Hector's dolphin. This name is considered a junior synonym of Cephalorhynchus hectori. No type specimen is known to exist.

\section{Genus Phocoenoides Andrews, 1911 - Dall's porpoises}

\section{Phocoenoides dalli (True, 1885) - Dall's porpoise}

\section{Phocaena dalli True, 1885}

This porpoise species was described from a specimen collected in the "strait west of Adakh (Adak) Island" in the Aleutian Islands, Alaska, in 1873 by W. H. Dall. The type description contains measurements and reasonably accurate illustrations of external appearance and color pattern. The type (a skull only) is in the USNM (No. 21762). This is the senior synonym and valid name of Dall's porpoise.

\section{Phocoenoides truei Andrews, 1911}

Andrews (1911b) erected the genus Phocoenoides and described this new species, based upon an adult male specimen collected by a local whaling ship from Aikawahama, Rikuzen Province, Japan. The detailed type description has measurements and includes photos of the skull and external appearance. The holotype specimen, a complete skull and skeleton, resides in the AMNH (No. 31425; Goodwin, 1953). The validity of the species has been controversial, being at various times considered a full species, a subspecies, or just a geographic form/color morph. However, based mostly on the assessment by Escorza-Treviño et al. (2004), this nominal species is now considered a subspecies of Phocoena dalli (Phocoenoides dalli truei).

\section{Genus Phocoena G. Cuvier, 1816 - common porpoises \\ Phocoena phocoena (Linnaeus, 1758) - harbor
porpoise}

\section{Delphinus phocoena Linnaeus, 1758}

Linnaeus described this cetacean in his 10th edition of Systema Naturae, as the common porpoise of the "Oceano Europaeo, \& Balthico." No type specimen was designated, but it was clear that he was describing what we now know as the harbor porpoise. This is the senior synonym and valid name for that species. Variant spellings include phocaena and phocena.

\section{D[elphinus] phocaena fuscus Kerr, 1792}

Although this name is sometimes considered to be a junior synonym of Phocoena phocoena, it is not a new species name (as it has sometimes erroneously been treated), but a subspecies name, and therefore is outside the scope of this review.

\section{Delphinus ventricosus Lacépède, 1804}

Lacépède's nominal species was described from the River Thames, England. No type specimen was designated. Based on the description and the painting included in Lacépède's volume, the name is generally considered to be a junior synonym of Phocoena phocoena. Variant spellings include ventricosa.

Phocaena communis Lesson, 1827

This was a replacement name for Delphinus phocoena. The account is quite short, with no illustrations of the appearance of the species. The name is a junior synonym of Phocoena phocoena.

\section{Phocaena tuberculifera Gray, 1865}

Gray (1865b) described a supposedly new species of harbor porpoise from a specimen collected at the mouth of the Thames River, England, and stored at the Royal College of Surgeons (No. 2965). The type is now in the NHMUK (No. 1865.12.8.43; Table 3) and consists of a skull and full skeleton (along with the skin preserved "in spirits"). The name is considered to be a junior synonym of Phocoena phocoena. 


\section{Phocoena vomerina Gill, 1865}

In a brief account, with no figures, Gill described this species of porpoise from two skulls (syntypes), one from Puget Sound, Washington, and the other from San Francisco, California, both stored at the USNM (No. 4149, 4746/4402). The name is considered to be a junior synonym of Phocoena phocoena, and the senior synonym of the recognized subspecies Phocoena phocoena vomerina (SMM, 2020). See history in Fisher and Ludwig (2016).

\section{Phocaena brachycium Cope, 1865}

This species was based on two skulls from the Museum of Essex, Salem, Massachussetts (Cope, 1865a). The specimens were collected in the nearby harbor. Hershkovitz (1966) speculated that these may now be in the USNM, but they may be lost as they are not listed in Poole and Schantz (1942), nor in Fisher and Ludwig (2016). The descriptive account is moderately detailed, including some measurements. The name is now considered a junior synonym of Phocoena phocoena. Variant spellings include brachcium.

\section{Phocaena americana J. A. Allen, 1869}

Allen introduced this name in a very brief account, with little description, saying that he did not know if this species was separate from Phocaena brachycium Cope, 1865 (Cope, 1865a). Allen mentioned that the species was common in Massachussetts. No formal type specimen was designated, but he did say that there are several specimens in the MCZ. The name is a synonym of Phocoena phocoena.

\section{Phocoena rondeletti Giglioli, 1870}

This species was described by Giglioli in a very brief account. He mentioned that it was a "common species on the western coasts of Europe, it rarely seems to venture into the Mediterranean." No type specimen was designated, and the name is now considered a junior synonym of Phocoena phocoena.

\section{Phocaena lineata Cope, 1876}

Cope described this nominal species from a specimen collected at the harbor of New York. The specimen was sent to the USNM, where a plaster cast of it is still preserved (USNM 12481, 15781). Several additional specimens, consisting of skeletal material, were also obtained. His account is quite detailed, with information on both skeletal and external morphology, but no figures. See history of the holotype specimen in Fisher and Ludwig (2016). The name is a junior synonym of Phocoena phocoena.

\section{Phocoena relicta Abel, 1905}

This new species was described in a very detailed account, from syntypes collected on the Crimean coast of the Black Sea. Abel compared his Black Sea harbor porpoise with other known species of harbor porpoise. His account includes two very accurate drawings of the external appearance of the species. The two type skeletons are reportedly in the Academy of Science, Sebastopol, Russia. The name is a junior synonym of Phocoena phocoena, and the senior synonym of the subspecies Phocoena phocoena relicta (ViaudMartínez et al., 2007; SMM, 2020).

\section{Phocoena spinipinnis Burmeister, 1865 - Burmeister's porpoise}

\section{Phocaena spinipinnis Burmeister, 1865}

The well-known naturalist Hermann Burmeister described this porpoise species from a $162 \mathrm{~cm}$ specimen collected near the mouth of the Rio de la Plata, Argentina (Burmeister, 1865a,b). Burmeister's species account is moderately detailed, with good illustrations of the unique dorsal fin and the skull of this species. The mounted skin of the type specimen still exists at MACN-Ma (No. 20810; Vaccaro and Piantanida, 1998), but the skull and postcranail skeleton are missing. Gallardo (1917) presented a photograph of the mounted, stuffed skin of the holotype. This is the senior synonym and valid name for Burmeister's porpoise. Variant spellings include spinipennis.

\section{Phocaena philippii Philippi, 1893}

This nominal species was described by Philippi in 1893. His account is short, but includes information on coloration and external form. Philippi included a plate (plate 3, fig. 2), which shows an animal that can only be what we now know as Burmeister's porpoise. No type specimen is known. The name is considered a junior synonym of Phocoena spinipinnis.

\section{Phocoena dioptrica Lahille, 1912 - spectacled porpoise}

\section{Phocoena dioptrica Lahille, 1912}

This species was described by Lahille from a pregnant female specimen stranded alive at Punta Colares, near the Rio de la Plata, Buenos Aires, Argentina. His species description is very complete, and includes infomation on both external and skeletal anatomy, measurements, comparisons to related phocoenid species, 
and photos of the adult specimen and its fetus. Unfortunately, the skeleton of the adult female has been lost, but the fetus is still preserved in alcohol at the MACN-Ma (No. 12.14; Varela et al., 2010). This is the senior synonym and valid name of the spectacled porpoise.

\section{Phocaena stornii Marelli, 1922}

In 1922, Marelli described Phocaena stornii from a skull collected in Tierra del Fuego. His account is very thorough, with multiple photos of the skull, measurements, and comparisons to other species of porpoise. The holotype skull is still present at MACN-Ma (No. 16407; Varela et al., 2010). This name is a junior synonym of Phocoena dioptrica.

\section{Phocoena sinus Norris and McFarland, 1958 - vaquita}

\section{Phocoena sinus Norris and McFarland, 1958}

Norris and McFarland described this new species of Gulf of California porpoise from three skulls found on the dunes and beaches near San Felipe, Baja California, Mexico, in 1950 and 1951. The holotype is in the MVZ (No. 120933, skull only), and the two paratypes are labeled MVZ 120934 and USNM 303308. Their paper presented a very detailed description, including comparative measurements and multiple photographs of the skull. The external appearance of the species was not known at the time, and it was assumed that it was very similar to that of Phocoena phocoena. It was not until 1987 that the examination of several fresh specimens allowed the external form and coloration to be described (Brownell et al., 1987). This is the valid name for the vaquita.

\section{Genus Neophocaena Palmer, 1899 - finless porpoises}

Neophocaena phocaenoides (G. Cuvier, 1829) Indo-Pacific finless porpoise

\section{Delphinus phocaenoides G. Cuvier, 1829}

The type specimen was supposedly collected from the Cape of Good Hope, South Africa, by French naturalist J. J. Dussumier in 1827. Although there has been a good deal of controversy about the collection locality of the type specimen (see Jefferson, 2002), it is now generally accepted that the specimen was actually collected along the Malabar coast of India. The holotype skull is preserved in the MNHN (No. A.3086), and an unpublished manuscript by the collector J. J. Dussumier (MNHN manuscript No. 894; Arvy, 1972b) shows an outline of the type specimen, which clearly shows it to be a finless porpoise. Robineau (1990) also provided photos of the skull and an outline drawing of the body.
I examined and meausured the holotype skull (Jefferson, 2002; Table 3). This is the senior synonym and valid name of the Indo-Pacific finless porpoise.

\section{Delphinapterus molagan Owen, 1866}

Owen described this species based on a drawing in the possession of Mr. W. Elliot, of a young specimen (32 inches, or $81 \mathrm{~cm}$, long) from India. Apparently, no type specimen was collected. It is clearly a finless porpoise, owing to the description. Based on the locality of origin of the drawn specimen, this name is considered a junior synonym of Neophocaena phocaenoides.

\section{Neomeris kurrachiensis Murray, 1884}

Murray provided a short, but detailed description, lacking any illustrations. The type specimen was collected from Kurrachee (Karachi, in present-day Pakistan) (Murray, 1884). There is apparently a finless porpoise skull in the Karachi Museum, which is presumably the type of this species, but as far as I know, it has not been examined since being collected in the late 1800 s. This name is considered to be a junior synonym of Neophocaena phocaenoides.

\section{Neophocaena asiaeorientalis (Pilleri and Gihr, 1972) - narrow-ridged finless porpoise}

\section{Delphinus melas Schlegel, 1841}

This species was described by Schlegel (1841b) based on a specimen from Nagasaki, Japan, and the holotype (an incomplete skeleton) is in the collection of the RMNH (No. 23079). I examined it and measured the skull for Jefferson (2002; Table 3). Schlegel's (1841b) brief description was followed by a more detailed description (Schlegel, 1844, often erroneously cited as Temmink and Schlegel, 1844). Van Bree (1973b) clarified that the name was pre-occupied by Delphinus melas (= Globicephala melas). Schlegel's name is thus a junior primary homonym of Delphinus melas Traill, 1809, and therefore cannot be used for the narrow-ridged finless porpoise. Variant spellings include melus.

\section{Neomeris asiaeorientalis Pilleri and Gihr, 1972}

Pilleri and Gihr (1972a) provided a detailed description, with photos and measurements, describing this species of narrow-ridged finless porpoise from a specimen from the Yangtze River in the collection of the MCZ, Harvard University (MCZ 19998). I examined the type for Jefferson (2002; Table 3). This is the senior synonym and valid name of the narrow-ridged finless porpoise. If future studies show the Yangtze 
River form to be a separate species (see Zhou et al., 2018), the name asiaeorientalis would apply to that species.

\section{Neophocaena sunameri Pilleri and Gihr, 1975}

This species is a renaming of Delphinus melas Schlegel, 1841 (Schlegel, 1841a), the species earlier described from Japanese waters, but later found to be pre-occupied (see above). I examined and measured the holotype, a specimen in the RMNH (No. 23079), for Jefferson (2002; Table 3). The same holotype is used for Delphinus melas. The name is a junior synonym of Neophocaena asiaeorientalis, and this form is currently recognized as a valid subspecies, Neophocaena asiaeorientalis sunameri (Jefferson and Wang, 2011; SMM, 2020).

\section{Genus Platanista Wagler, 1830 - Ganges and Indus dolphins}

\section{Platanista gangetica (Lebeck, 1801) - South Asian river dolphin}

\section{Delphinus gangeticus Lebeck, 1801}

This river dolphin species was described in 1801 in two separate publications, one by Heinrich Julius Lebeck and the other by William Roxburgh. There has been much controversy about which author should be credited with the type description and which reference has priority. Pilleri $(1972,1978)$ made an elaborate case for Roxburgh being the original describer, largely based on the notion that Lebeck had seen Roxburgh's early account and plagiarized much of it. However, after extensive research, Kinze (2000) found original elements in both papers and rejected the argument of plagiarism; he further deduced a publication date of 24 August 1801 for Lebeck's account. No date could be ascertained for Roxburgh's, and thus priority was awarded to Lebeck. Lebeck's type description is based on an adult male specimen collected in November 1797 about $11 \mathrm{~km}$ from Calcutta, and it is thought that this is the same material that Roxburgh based his description on (thereby making Roxburgh's name a junior objective synonym). This type specimen was presented to the Royal College of Surgeons, but was apparently destroyed in World War II. Fortunately there is a cast of the rostrum and part of the mandible still in the NHMUK (No. 1884.5.3.1 or No. 1939.4523). Delphinus gangeticus is considered the senior synonym and valid name of the Ganges river dolphin.

\section{Delphinus gangeticus Roxburgh, 1801}

See detailed description above under Delphinus gangeticus Lebeck, 1801. The Roxburgh type description is moderately detailed, and includes an illustration of the external features. All that remains is a cast of the rostrum and part of the mandible (NHMUK 1884.5.3.1 or 1939.4523). Roxburgh's name represents an unusual case, which is considered both a junior objective synonym and junior objective homonym of Delphinus gangeticus Lebeck, 1801.

\section{Susu platanista Lesson, 1828}

This name was cited in Hershkovitz (1966) as a synonym for the South Asian river dolphin, but in Lesson's monograph, he used "sousou plataniste" only as a common name, and the Latin name he used in the description on p. 215 is Delphinus gangeticus Lebeck. "Susu platanista" only appears in the index on p. 440 (perhaps a printing error?). Therefore, Susu platanista Lesson is not a true scientific name, and should thus be considered a nomen nudum.

\section{Platanista minor Owen, 1853}

Owen described a new type of river dolphin from "the Indus" based on a skull collected by David Wallich (specimen No. 2481 in the Royal College of Surgeons, London). He described it as a minor variety, Platanista gangetica, var. minor, and not a species or subspecies. But despite this fact, the ICZN has determined that such names published before 1961 are available in zoological nomenclature (see Articles 10.2 and 45.6). The type specimen in the Hunterian $\mathrm{Mu}-$ seum was apparently destroyed during a World War II German bombing raid, and thus no longer exists (Pilleri and Gihr, 1977). There has been much controversy over the years as to whether this is a valid species, though new evidence using a variety of markers indicates that it should be considered a distinct species (Braulik et al., 2021). However, until it is officially recognized as such, this name is considered a junior synonym of Platanista gangetica, and the senior synonym of the subspecies Platanista gangetica minor (van Bree, 1976; SMM, 2020).

\section{Platanista indi Blyth, 1859}

In 1859, Blyth described Platanista indi as a new species, based on a skull collected by Sir Alexander Burnes. The disposition of the type is not mentioned in the original publication, but both Sclater (1891) and Hershkovitz (1966) stated that the type skull was in the Asiatic Society Museum, Calcutta (now known as the Indian Museum). Pilleri and Gihr (1977) stated that neither Blyth's nor Owen's types could be found in the 1970s, and therefore used this as a justification to designate a neotype for the Indus river dolphin (No. 623 in the Pilleri collection, which is now in the possession of the Staatliches Museum für 
Naturkunde Karlsruhe, Stuttgart, Germany, where it has the number SMNS 45643; see Dieterlen et al., 2013). However, this neotype has no standing in zoological nomenclature (Rice, 1998), and for the reasons discussed above Platanista indi is considered to be a junior synonym of Platanista gangetica.

\section{Genus Inia d'Orbigny, 1834 - Amazon river dolphins}

\section{Inia geoffrensis (Blainville in Desmarest, 1817) - boto or Amazon river dolphin}

\section{Delphinus rostratus Shaw, 1801}

George Shaw described this species in 1801 based on a type that was possibly in the possession of the Hunterian Museum (Eschricht, 1851, 1852), which has also been known as the Museum of the Royal College of Surgeons. Its current location is not known, though it is not in the NHMUK. The exact type locality is unknown, but the species was "supposed to inhabit the Indian Seas." The name has in the past erroneously been considered to be a synonym of Steno bredanensis (see West et al., 2011) or Platanista gangetica, and its questionable identity might lead some to consider this a nomen dubium. However, recently Smeenk (2018), in a very detailed and exhaustive historical review of the name Delphinus rostratus, showed that the type is actually an example of the Amazon river dolphin. Therefore, this is the senior synonym of that species and should be used as its name. However, as Shaw's name has not been in use for over 120 years, Smeenk (2018) suggested that a request to suppress the name (and thereby to conserve geoffrensis) should be made to the ICZN. However, a ruling of the ICZN should not be required in this case, and a request to designate this name as a nomen oblitum has been made (Jefferson, 2021). Variant spellings include rostrats.

\section{Delphinus geoffrensis Blainville in Desmarest, 1817}

The Amazon river dolphin was known to science well before Linnaeus' (1758) binomial system of nomenclature came into use (see Romero et al., 1997), but names used before 1758 have no standing in modern taxonomic nomenclature. A. G. Desmarest, in the encyclopedia he edited, described this species based on material at the MNHN in Paris (No. 1870-274). There has been quite a bit of confusion about the authorship of this name, as it is not always clear who wrote what sections of the encyclopedia. However, the relevant text was apparently written by Desmarest, who credited the name to Blainville; therefore the authorship should be listed as "Blainville in Desmarest, 1817." The type specimen is a mounted skin (painted to simulate natural color) with skull, from either the Rio Negro or from the lower Amazon and its affluents, but supposedly brought to Paris from "Portugal" (presumably Brazil) by Professor G. SaintHilaire. It is illustrated in Robineau (1989). The skull has been extracted and studied by van Bree and Robineau (1973), who also included measurements and photos. Although this is not the oldest name for the Amazon river dolphin, it has been in nearly continuous use for that species for over 100 years. Therefore, a specific proposal has been made to conserve this name (a nomen protectum) as the valid name for the Amazon river dolphin (see Smeenk, 2018, for further justification). Variant spellings include geoffroyensis, geoffroyii, and geoffroyi.

\section{Delphinus shawensis Blainville in Desmarest, 1817}

Desmarest examined two river dolphin skulls from an unknown location (but thought to be from the "upper Amazon of Brazil") in the Museum of the Royal College of Surgeons in London (current location not known). He described them as a new species, Delphinus shawensis, in honor of George Shaw, who had apparently examined the same specimens (Eschricht, 1851, 1852). Smeenk (2018) provided an English translation of the type description, and found that the holotype (an incomplete skull) is the same as for Delphinus rostratus Shaw, 1801. This name is considered a new name for Delphinus rostratus, and thus the name should technically be viewed as a junior objective synonym of Inia geoffrensis (see above under Delphinus rostratus Shaw, 1801). Variant spellings include schawensis.

\section{[Delphinus] frontatus G. Cuvier, 1823}

Cuvier described this species from an unknown locality in South America, presumably somewhere in Brazil (though Lisbon, Portugal is listed in the account). The type material is thought to be currently kept at the MNHN in Paris (needs to be confirmed). This species may have originally been based on composite material (a skin and series of undocumented skulls in the MNHN in Paris, including some material from a specimen of Steno bredanensis). But Cuvier later, in the seventh part of this work (published in Cuvier, 1825), restricted the name Delphinus frontatus to the mounted skin only. The skull referred to in Cuvier's "Addition Importante" note on p. 400 (shown in plate 21, figs. 7,8 ) appears to be a rough-toothed dolphin skull (and in fact, Delphinus frontatus has sometimes been considered to be a synonym of Steno bredanensis - see West et al., 2011). With this restriction of the type material to exclude the skull mentioned above, Delphinus fron- 
tatus has now been identified by Smeenk (2018) as a junior synonym of Inia geoffrensis.

\section{Delphinus amazonicus von Spix and von Martius, 1831}

Von Spix and von Martius introduced this nominal species from material collected from the lower reaches of the Rio Negro in the Amazon River basin. The type (skin and skull?) originally may have been in the Munich Zoological Collection, but appears to have been lost, most likely during World War II (see Pilleri and Arvy, 1981). It is clear that the type material is associated with the Amazon river dolphin. The name is therefore considered a junior synonym of Inia geoffrensis.

\section{Inia boliviensis d'Orbigny, 1834}

D'Orbigny described a new species of Amazon river dolphin from type material collected from Fort du Principe de Beira, along the Itenez River, Bolivia. The holotype skull is still housed in the MNHN (No. A.11478). The original account by d'Orbigny is rather detailed, with some measurements and crude illustrations of the skull and external appearance (figs. 1-3). Van Bree and Robineau (1973) also provided a very detailed description, measurements, and photos of the skull of the type specimen. Although sometimes viewed as a valid species, it has not been accepted as such by the Committee on Taxonomy (SMM, 2020). This name is a junior synonym of Inia geoffrensis, and the senior synonym of the subspecies Inia geoffrensis boliviensis (SMM, 2020).

\section{Delphinus inia Rapp, 1837}

This short account by Rapp provides a replacement name for Inia bolivensis d'Orbigny. There is no type specimen, and no figures are provided. The name is thus a junior synonym of Inia geoffrensis.

\section{Inia araguaiaensis Hrbek et al., 2014}

Hrbek and colleagues reported the discovery of a supposedly new species of river dolphin from the Araguaia basin of Brazil. The type description is rather detailed and uses both morphological and molecular markers. The focus is on the genetic information, and the morphological analyses are based on a very few data (though they do provide photos of the skull). The type material was deposited at the Mammal Collection of the National Institute for Amazonian Research, in Manaus, Brazil (No. INPA MA 44). However, the sample sizes for some of the analyses were extremely small, and there are methodological problems with some analyses. As a result, the species has not been accepted by the Committee on Taxonomy (SMM, 2020), and the name is at present considered a junior synonym of Inia geoffrensis.

\section{Genus Pontoporia Gray, 1846 - franciscanas \\ Pontoporia blainvillei (Gervais and d'Orbigny, 1844) - franciscana}

\section{Delphinus blainvillei Gervais and d'Orbigny, 1844}

This species of river dolphin was described by Gervais and d'Orbigny from a skull collected by M. Freminville, and deposited in the MNHN. The type specimen was collected near the mouth of Rio de la Plata, near the city of Montevideo, Uruguay. Gervais and d'Orbigny's account is rather brief, with no illustrations accompanying it. In a later publication, d'Orbigny and Gervais (1847) provided a more detailed description of the species, in addition to useful figures showing the skull and external appearance. A detailed history and discussion of the type is provided in Robineau (1989). This is the senior synonym and valid name for the franciscana. Variant spellings include blainvillii.

\section{Pontoporia tenuirostris Malm, 1871}

Malm described this nominal species from a mounted, stuffed skin and skull in the Goteborg Naturhistoriska Museum, in Sweden. The type was collected from near Montevideo, Uruguay. Malm's description is very thorough, with extensive information on the skull and skeleton, associated measurements, and excellent figures showing the external appearance and various views of the skull (plate 2, fig. 10). The information and figures provided show clearly that the type is what we now know as the franciscana. This name is thus considered a junior synonym of Pontoporia blainvillei.

\section{Genus Lipotes Miller, 1918 - baijis}

\section{Lipotes vexillifer Miller, 1918 - baiji}

Lipotes vexillifer Miller, 1918

Miller erected the new river dolphin genus Lipotes and described this species from an adult male specimen collected from Tung Ting Lake, about 600 miles up the Yangtze River, People's Republic of China. The specimen was collected by Charles M. Hoy in February 1916, and the skull and cervical vertebrae are preserved in the USNM (No. 21293 or 218293). Detailed information, including photographs and measurements, were presented in Miller's (1918) paper (see also van Bree, 1975), and no other nominal species have been described for the genus Lipotes, which regrettably became extinct some time in the first decade of the 2000s (Turvey et al., 2007). 


\section{Unknown genus/species - incertae sedis}

\section{Monodon spurius Fabricius, 1780}

Based on a short but moderately detailed description, with no illustrations, Fabricius used this name to describe the "anarnak" of Greenland, a term now generally considered to refer to the northern bottlenose whale (Hyperoodon ampullatus) (see Hershkovitz, 1966). No type specimen was collected, and the name, while very likely referring to the narwhal, is now considered to be a nomen dubium (Hershkovitz, 1966).

\section{Delphinus tursio Fabricius, 1780}

Fabricius introduced this name for the "nesarnack" of Greenland (see also under Delphinus nesarnack Lacépède, 1804), and although no type specimen was collected, it is thought to have been based on a composite description of a number of North Atlantic delphinid species (see Hershkovitz, 1966). The name may have been intended to refer to a bottlenose dolphin, perhaps following Gunnerus (1768) and it was used for that species frequently in the 1800 s. But True (1903) showed that the description does not match the bottlenose dolphin. The name is now considered to be a nomen dubium. This name is also a junior homonym of Delphinus tursio Gunnerus, 1768.

\section{D[elphinus] feres Bonnaterre, 1789}

This name was used by Bonnaterre to describe a dolphin collected from the mouth of the Gulf of Grimaud, southeastern France (in the Mediterranean Sea). The type was a skeleton, reportedly in the museum of the seminary of Frejus, France. However, it is unknown if the type still exists, and as the description is unclear and there is no illustration, the species is considered unidentifiable, a nomen dubium. True (1903) suggested that it might have been a pilot whale (Globicephala sp.).

\section{Delphinapterus senedetta Lacépède, 1804}

The moderate-length description of this nominal species may have been referring to a beluga (e.g., lack of dorsal fin, 8-9 teeth in each tooth row), but some characters do not fit (e.g., long, pointed muzzle and occurrence in the Mediterranean). No type specimen was deposited, and so it is considered to be unidentifiable, a nomen dubium. In fact, Hershkovitz (1966) remarked that it may be mythical.

\section{Anarnack groenlandicus Lacépède, 1804}

This is a new name for Monodon spurius Fabricius, which is considered to be a nomen dubium (though probably referring to the narwhal). The account is short, and does not include any figures of the animal. This name is also a nomen dubium.

\section{D[elphinus] bonnaterrei Tiedemann, 1808}

This very brief account with no illustrations provides a new name for Delphinus feres Bonnaterre (which may have been a pilot whale). Due to uncertainty about its true identity, it is a nomen dubium.

\section{Delphinus siculus Rafinesque Schmaltz, 1810}

The short description of this species (with no illustration) does not permit identification, though True (1903) suggested that it might have been a bottlenose dolphin. It was described from Sicily, in the Mediterranean Sea, but no type specimen was collected. The name is a nomen dubium.

\section{D[elphinus] dubius G. Cuvier, 1812}

The very brief description of this species, consisting of only three lines of text (with no illustrations), is not sufficient for identification. When describing this nominal species of dolphin, a type specimen was not designated by Cuvier in his original account of 1812. Cuvier's (1823) later description of Delphinus dubius was based on several skulls in the Paris Museum (MNHN) from an unknown locality in the Atlantic Ocean, and included a table with measurements of one of the skulls. Perrin et al. (1987) stated that a skull in the Paris Museum (A-3033, labeled Delphinus froenatus) appeared to fit with the dubius syntype measurements, but Robineau (1990) found that at least one other skull in the MNHN collection (JAC 1972-184) was also very close, and therefore that it was impossible to designate a lectotype from the series. Perrin et al. (1987) found that the type series was likely a composite that applied to both species of spotted dolphins (Stenella attenuata and Stenella frontalis). As there is uncertainty about the original material on which Cuvier based this species, Robineau (1990) considered Delphinus dubius to be a nomen dubium, and I concur. Variant spellings include dubia.

\section{[Delphinus] coronatus Freminville, 1812}

Freminville's rather short description and illustration were based on animals observed at sea in the North Atlantic off Spitzbergen, north of $74^{\circ} \mathrm{N}$. In his outline figure of the species (plate 1, fig. 11; also reproduced in Arvy, 1972b), the long beak and dorsal fin set far back on the body suggest a possible beaked whale species, as does the stated length of about 10 $\mathrm{m}$. However, the information indicating 48 conical 
and very sharp teeth in the upper jaw and 30 in the lower is in conflict with this, and this information does suggest a species of dolphin. All considered, the description and drawing are not identifiable to species or even genus. No type specimen was collected. The name is therefore a nomen dubium.

\section{Delphinus pernettensis Blainville in Desmarest, 1817}

Giving credit to Blainville, A. G. Desmarest based this species on a drawing published by Pernety (1769) of a dolphin captured, apparently off the Cape Verde Islands at $6^{\circ} 43^{\prime} \mathrm{N}, 25^{\circ} 17^{\prime} \mathrm{W}$ (note that a position of $16^{\circ} 44^{\prime} \mathrm{S}, 35^{\circ} 10^{\prime} \mathrm{W}$ given by Hershkovitz [1966] is off Brazil and is not the type locality, according to van Bree [1971d]). Pernety's description of the dolphin school from which this specimen was collected may have been of a mixed school containing both spotted and spinner dolphins. No type specimen was retained or deposited. The sketch (plate 2, fig. 1 in the original French 1769 edition, and plate 14, fig. 34 in the English translation in Pernety [1771]; reproduced in van Bree [1974b] and in Pilleri and Arvy [1981]), while somewhat primitive, shows obvious diagnostic features of the pantropical spotted dolphin (Stenella attenuata). Although Perrin et al. (1987) suggested that the animal drawn (effectively the type specimen) was likely a pantropical spotted dolphin, without a specimen to examine, the specific identity cannot be certain. It is best considered a nomen dubium. In any event, the name has been suppressed by the ICZN and is no longer available (van Bree, 1974b,c; Melville, 1977). Variant spellings include pernetyi, pernettyi, and pernettyensis (note that Delphinus pernettyi Desmarest, 1822 appears to be simply an emendation of his earlier name).

\section{Delphinus bertini Duhamel in Desmarest, 1817}

The brief description does not permit identification with any certainty (and could even refer to a pygmy or dwarf sperm whale), and no illustration was provided in the reference by Desmarest. This species was based on the dauphin de Bertin of Duhamel du Monceau (1782, plate 10, fig. 3). The illustration in that reference shows the head of a long-beaked dolphin, which could be any of several species (though Hershkovitz [1966] suggested that it might be a Risso's dolphin). The name is therefore a nomen dubium.

\section{Delphinus niger Lacépède, 1818}

Lacépède apparently based this species on a Japanese drawing of a dolphin, which was mostly black with a smooth rostrum. It cannot be identified to species. No type specimen was designated, and there are no illustrations included in the description. The name is considered a nomen dubium.

\section{Delphinus boryi Desmarest, 1822}

Desmarest (1822) provided a fairly detailed description of this species, but with no illustrations. It was based on animals of an unrecognized species observed at sea between Madagascar and the Mascarene Islands, and no type specimen was obtained. The description is not diagnostic, though the mention of the lower body of a light gray with spots suggests possibly the pantropical spotted dolphin. The name represents a nomen dubium.

\section{Delphinus anarnacus Desmarest, 1822}

This is another name for Monodon spurius Fabricius, which is considered to be a nomen dubium. This name is therefore also a nomen dubium.

\section{Delphinus epiodon Desmarest, 1822}

This is another species based on a description that does not allow identification. No illustrations were provided. Desmarest described it as having a lower jaw shorter than the upper, and stated that it is found in the seas of Sicily in his account. No type specimen was collected, and the name is considered a nomen dubium.

\section{Delphinus rhinoceros Quoy and Gaimard, 1824}

This species was based on animals observed at sea between Hawaii and Australia at $5^{\circ} 28^{\prime} \mathrm{N}$. It was described as twice the size of a "common porpoise" (probably referring to Tursiops truncatus, which would make it about 5-7 m). The illustration in Quoy and Gaimard's atlas (plate 2, fig. 1) of this animal swimming at sea shows what looks like a dolphin with two dorsal fins, and a black body with large white blotches. No cetacean species has two dorsal fins. It cannot be identified (it was possibly a shark or mythical creature), and the name is a nomen dubium.

\section{Delphinus leucocephalus Lesson, 1826}

This is another species Lesson presumably based on at-sea sightings, this time in the South Pacific near the Tuamotus Islands (Dangereux Archipel). The characteristics given in the short account are quite generic and not identifiable, and there is no illustration. Lesson and Garnot (1827) redescribed it, but provided little else that would help identify it. As suggested by 
Hershkovitz (1966), I consider this name to be a nomen dubium.

\section{Delphinus malayanus Lesson, 1826}

This species was based on a specimen captured between Java and Borneo, Indonesia. The original description was quite brief with no illustrations. Although no type specimen was mentioned by Lesson (1826), Lesson and Garnot (1827) described a harpooned 5'11" $(1.8 \mathrm{~m})$ specimen, which they illustrated to show the perceived external characters of this species. Van Bree ${ }^{8}$ considered Delphinus malayanus to be synonymous with Sousa plumbea, due to the presence of "ridges" on the tail stock, and made an argument suggesting that Delphinus malayanus would actually have taxonomic priority over Sousa plumbea. He then further suggested that Delphinus malayanus should be suppressed by the ICZN, but this proposal seems to have not gotten anywhere. The illustration in the atlas for Lesson and Garnot's voyage shows a longbeaked dark dolphin, which could be a humpback dolphin (but does not exclude other species), although the dorsal fin does not resemble any from the genus Sousa. Schlegel (1841b) was able to obtain three specimens of what he considered this species (one from Borneo and two from Java), and his illustration (plate 1, fig. 2) of the skull of one of them (presumably at the RMNH) and description of the specimen, including tooth counts, can only be a humpback dolphin of the genus Sousa. I here disagree with van $\mathrm{Bree}^{8}$, who stated that this specimen was an example of the species Stenella attenuata. Lesson's Delphinus malayanus has in the past variously been considered to be synonymous with either Stenella dubia or Sousa plumbea (Hershkovitz, 1966). Perrin et al. (1987) earlier reviewed the controversy surrounding this name, and considered it a nomen nudum. I feel reasonably confident that Lesson's Delphinus malayanus corresponds to a humpback dolphin (and based on currently-understood distribution, this would be Sousa chinensis; see Jefferson and Rosenbaum, 2014), and that the name could be considered a synonym of that species. However, taking a conservative approach, and recognizing the residual uncertainty about its true identity, I agree with Kinze (2015), and think it better to consider the name a nomen dubium.

\section{Delphinus minimus Lesson and Garnot, 1827}

The identity of this nominal species cannot be ascertained. The description was based on a large school

\footnotetext{
${ }^{8}$ Van Bree, P. J. H. 1986. On Delphinus malayanus Lesson, 1826 and on skulls of Delphinus malayanus Schlegel, 1841 (Cetacea, Delphinoides). Unpubl. manuscript, 5 p.
}

(thousands) seen at sea near the Solomon Islands, and they were said to be all less than 2 feet $(0.6 \mathrm{~m})$ in length. No dolphin species is known to be this small as adults, and no illustration was provided. Therefore, the name is a nomen dubium.

\section{Delphinus maculatus Lesson and Garnot, 1827}

There is a short account of this species, based on atsea sightings, this time in the South Pacific near the Tuamotus Islands, $18^{\circ} \mathrm{S}, 137^{\circ} \mathrm{W}$. The characteristics given are not identifiable, and there is no illustration. No type specimen was collected. The name is a nomen dubium.

\section{Delphinus superciliosus Lesson and Garnot, 1827}

Lesson and Garnot provided a description of a dolphin harpooned at $44^{\circ} \mathrm{S}$ near Cape Diemen (southern Tasmania). Although their description was brief, the illustration of this species in the accompanying atlas (plate 9, fig. 2) shows what resembles a dusky dolphin. However, the species is not identifiable with any certainty and may possibly be an hourglass dolphin. The type specimen was not preserved, or was discarded or lost. In their taxonomic revision of the genus Lagenorhynchus, the name was regarded as a nomen dubium by Vollmer et al. (2019), and I follow their lead here. Variant spellings include supercillosus.

\section{Delphinus nesarnac Lesson, 1827}

This is another name for Delphinus tursio Fabricius, which is considered to be a nomen dubium. The description is short, with few details and no figures. Lesson's name is also a nomen dubium.

\section{[Delphinus] fabricii Billberg, 1827}

The brief description provides a new name for Delphinus tursio Fabricius, which is considered to be a nomen dubium, and therefore this species would also be considered a nomen dubium. No type specimen is known, though it is suspected that a bottlenose dolphin was being described. The date of this reference is in question, as there appear to be two versions, one with 1827 and the other with an 1828 publication date (I assume the former is correct).

\section{C[atodon] sibbaldi Fleming, 1828}

The very short description of this species, with no figures included, is not adequate to identify this species, described from the Orkney Islands. The animals were said to be 2-24 feet in length (0.6-7.3 m). There is no mention of the deposition of a type specimen. Although it has been viewed as a synonym of Del- 
phinapterus leucas, the name should be considered a nomen dubium.

\section{Delphinus harlani Fischer, 1829}

This is a new name for Delphinus intermedius Harlan (which was based on a misidentification). The brief description of this species does not allow an identification to be made, although Hershkovitz (1966) considered it a synonym of the long-finned pilot whale. No illustration was included, and the species is now considered a nomen dubium. The page number of the description is imprinted incorrectly - it is imprinted with 456, but it is actually page 656 .

\section{Delphinorhynchus santonicus Lesson, 1836}

Lesson described this species in 1836, from a specimen stranded at the mouth of the Charente River, France, but no holotype specimen is known to exist (van Bree and Duguy, 1972). The name has been considered to be a synonym of the rough-toothed dolphin (Hershkovitz, 1966; West et al., 2011). However, I question that identification, based on Lesson's stated tooth counts (33-38 in each tooth row) and his observation that the muzzle was separated from the rising forehead. There are thus strong doubts about its identity, and the illustration of the type (also reproduced in Lesson, 1841) shows a generic long-beaked dolphin that cannot be identified with any certainty, but is clearly not a rough-toothed dolphin (see also van Bree and Duguy, 1972). Therefore, taking a conservative view, the name is here considered a nomen dubium.

\section{Delphinus fulvifasciatus Wiegmann, 1840}

Wiegmann published a plate showing the external appearance (plate 361, fig. 1) of what could be a species of Delphinus or Stenella. This represents the first use of this species name (it is sometimes erroneously credited to Wagner, 1847, who only made reference to Wiegmann's plate in his list of plates). Since there was no description of distinctive features (and no reference to such), it might appear to be not available, but under ICZN Article 12.2.7, the name is indeed available.

\section{Delphinus carbonarius Wiegmann, 1844}

Wiegmann published a plate (plate 352, fig. 1) showing the external appearance of this nominal species, which represents the first use of this species name. Since there was no description or reference to distinctive features, it might appear to be unavailable; however, under ICZN Article 12.2.7, the name is indeed available. The illustration makes it clear that this is a pilot whale (Globicephala sp.), but it is not possible to determine of which species, thus the name is a nomen dubium.

\section{Delphinus rappii Reichenbach, 1846}

The type specimen was collected from the Cape of Good Hope, South Africa. It is reportedly in the Stuttgart Museum, but recent records do not mention it (Dieterlen et al., 2013). Reichenbach's very brief description, and accompanying illustration of external appearance, do not allow this species to be identified with any certainty. The illustration (plate 18, fig. 57) shows a dark dolphin with a long beak and whitish belly, which could be any of several species of delphinids. The skull does not appear to have been recently examined, and there is much uncertainty about its affinity. Since the name has not been used since 1846, it would technically qualify as a nomen oblitum. However, this is a moot point, as Perrin et al. (1987) considered that the name should remain incertae sedis (i.e., a nomen dubium).

\section{Delphinus sao Gray, 1846}

Supposedly a common dolphin, the type locality for Delphinus sao is Madagascar, which is potentially in the range of the Indo-Pacific common dolphin. No figures are provided with the short description. Gray stated that the type was located in the Paris Museum, and in fact there are currently two skulls in the Paris Museum (MNHN A 3037 and MNHN 1928162) that could correspond to the type. I examined these skulls and found both of them to be examples of pantropical spotted dolphin (Stenella attenuata), and tooth counts of neither skull match those reported for the type of Delphinus sao. Delphinus sao is often listed as a junior synonym of Delphinus delphis. However, due to the uncertainties described above, D. Robineau (footnote 11 in Jefferson and Van Waerebeek, 2002) has suggested that Delphinus sao Gray, 1846 be considered a nomen dubium (ICZN, 1999), and I concur.

\section{D[elphinus] carbonarius Wagner, 1847}

Wagner's description of this species is primarily based on the observations of Bennett (1840), who sighted these animals on a whaling voyage in the early 1800 s. This animal was known as the blackfish of the South Seas, and Bennett called them "Phocaena sp." There is much information provided on the habits and external anatomy, but none on the skull or skeleton. Tooth counts suggest Globicephala macrorhynchus, but other information suggests Globicephala melas. Wagner references the illustration in Wiegmann (1844, plate 
352, fig. 1). No type specimen was deposited in any museum. This name is a nomen dubium.

\section{Delphinus perniger Blyth, 1848}

Blyth provided a brief description with measurements for this new species from the Bay of Bengal. No illustration was provided. There is apparently a stuffed specimen in the Indian Museum, Calcutta, which has not been recently examined. Although this species may correspond to Tursiops sp., until the type is reexamined, there is uncertainty about the identification, and thus the name should be considered a nomen dubium.

\section{D[elphinus] oxyrhynchus Gray, 1850}

This name was used by Gray as a synonym for Steno? rostratus (= Steno bredanensis), without description (and with no corresponding illustration), but erroneously attributing it to Jardine. The name is considered a nomen nudum and a nomen dubium.

\section{Delphinus obtusus Schlegel, 1862}

There is supposedly an illustration of this species in plate 13 of Schlegel (1862), but that plate in fact contains only an illustration of a subspecies of the bottlenose dolphin labeled "Delphinus tursio obtusus." Although according to the ICZN (see Articles 10.2 and 45.6) such subspecific names published before 1961 can be available, this review generally does not deal with subspecies. Thus, this taxon is not considered further.

\section{Lagenorhynchus? nilssonii Gray, 1864}

Gray introduced this name for a dolphin species described by Nilsson as Delphinus obscurus, but occurring in the Swedish North Sea of Scandinavia. No type specimen was designated by Gray, but Nilsson (1847) based his description on a specimen (skull?) in the Museum of Lund. Lilljeborg (1866) rightly doubted the presence of Delphinus obscurus (a Southern Hemisphere endemic species) in Scandinavia. This name has at times been considered a junior synonym of Stenella frontalis, Lagenorhynchus obscurus, or Lagenorhynchus cruciger (see Hershkovitz, 1966), but the true identity is in question. Therefore, it is best to view this name as a nomen dubium.

\section{Globicephalus chinensis Gray, 1866}

Gray (1866a) made the brief description from observations at sea, based on the "Chinese Globicephala" of Blyth (1859). A type specimen obtained in the "China sea, near Luechen" was described as being black with a lighter belly, and having a very rigid dorsal fin. The description suggests that it was possibly a Risso's dolphin or pilot whale. It is believed that no type specimen is preserved, and the description is not adequate to confidently identify it to species or even genus. The name is a nomen dubium.

\section{Delphinus marginatus Lafont, 1868}

According to Hershkovitz (1966), this species was based on a misidentification, and therefore is not a new species name (Heyning and Perrin, 1994). No type specimen was collected, and there is essentially no description and no illustration of any identifying characters, so if it does represent a species of animal, it would be considered a nomen dubium. The name is also a junior homonym of Delphinus marginatus Duvernoy in Desmarest, 1856, and therefore cannot be valid.

\section{Delphinus caerulescens Giglioli, 1874}

Giglioli's description is rather detailed, but there is no illustration provided. The type description is based on specimens observed at sea between Kyushu and Tanega Islands, Japan. The information contained is not sufficient to identify it to species with any certainty. It is unknown if a type specimen exists, but it does not seem likely. This species may correspond to Tursiops aduncus, but the name should be considered a nomen dubium.

\section{Phocaena obtusata Philippi, 1893}

Philippi provided a moderately detailed description with measurements, and an illustration of the external appearance of this species. The illustration shows a blunt-headed small cetacean, with a dark back and white on the undersides, extending in lobes onto the flanks. It is not identifiable to species, although it most closely resembles a spectacled porpoise (Phocoena dioptrica). The type (skin only) may still exist at the NHM, Santiago, though this has not been recently confirmed. There have been suggestions that it is actually a specimen of Cephalorbynchus eutropia (Goodall et al., 1988b), but considering the lingering uncertainty, the name should be considered a nomen dubium.

\section{Delphinus chilensis Philippi, 1895}

Philippi's brief description with no illustration does not allow an identification to be made. It is likely a species of either Stenella or Delphinus (Hershkovitz, 1966). The type specimen is a fetus in alcohol, from an unknown locality, and it is uncertain if it still exists. The name is considered a nomen dubium. 


\section{Lagenorhynchus fitzroyi Lahille, 1899}

Lahille used this name from Waterhouse (1838a,b), and mistakenly thought his species was a dusky dolphin (now known as Lagenorhynchus obscurus). No type specimen was collected for this nominal species. The name has usually been viewed as a junior synonym of Lagenorhynchus cruciger, but considering the confusion about its identity, this name is probably best considered a nomen dubium.

\section{Conclusions}

Since the initiation of our binomial system of zoological nomenclature in 1758, 358 apparent scientific names have been proposed for species of dolphins, porpoises, and monodontid small cetaceans (however, for various reasons, five of them are not really species names). All 358 names are reviewed in this paper, and currently there are 50 species of dolphins, porpoises, and mondontid whales recognized as valid species. Of the remaining 308 names, most (231) are junior synonyms; however, there are 7 junior homonyms, 40 nomina dubia, 11 nomina nuda, 13 nomina oblita, and one simple emendation (see Appendix G for a summary).

Most of the 50 valid species are recognized under their senior synonyms, however there are four instances in which the senior synonym is a junior homonym of another species, thus precluding use of that name. In another six cases, preservation of stability dictates that the senior synonym should not be used as the valid name. These consist of cases in which a nomen conservandum has been recognized by the ICZN as the valid name, or a nomen protectum has been favored over the relevant senior synonym (which then becomes a nomen oblitum). By recognition of these arrangements, stability is maintained in small cetacean taxonomy, a high priority of the International Code of Zoological Nomenclature.

\section{Acknowledgments}

Thanks to the museum curators who accomodated me and assisted with finding specimens and their associated data, especially R. Sabin of the NHMUK and J. G. Mead and M. McGowen of the USNM. Discussions with several colleagues were influential in forming many of the ideas presented herein, in particular R. L. Brownell, C. Kinze, J. G. Mead, W. F. Perrin, and J. Y. Wang. B. Würsig assisted with translating several passages from German. I thank the editors, R. L.
Brownell, M. McGowen, and an anonymous reviewer for their suggestions on improving the manuscript.

\section{Literature cited}

Abel, O. V.

1905. Eine stammtype der delphiniden aus dem Miocän der halbinsel Taman. Jahrb. K. K. Geol. Reichsanstalt 55:375-392.

Allen, J. A.

1869. Catalogue of the mammals of Massachusetts: with a critical revision of the species. Bull. Mus. Comp. Zool. Harvard Univ. 1:143-252.

Amaral, A. R., B. D. Smith, R. M. Mansur, R. L. Brownell Jr., and H. C. Rosenbaum.

2017. Oceanographic drivers of population differentiation in Indo-Pacific bottlenose (Tursiops aduncus) and humpback (Sousa spp.) dolphins of the northern Bay of Bengal. Conserv. Genet. 18:371-381. https://doi.org/10.1007/ s10592-016-0913-7

Anderson, J.

1746. Nachrichten von Island Groenland und der strasse Davis, 328 p. Verlegis Georg Christian Grund, Hamburg, Germany.

Anderson, J.

1879. Anatomical and zoological researches: comprising an account of the zoological results of the two expeditions to western Yunnan in 1868 and 1875; and a monograph of the two cetacean genera, Platanista and Orcella, 2 vols. Bernard Quartich, London. [Apparently published in 1879 , not 1878 .]

Andrews, R. C.

1911a. Description of an apparently new porpoise of the genus Tursiops, with remarks upon a skull of Tursiops gillii Dall. Bull. Am. Mus. Nat. Hist. 30:233-237.

1911b. A new porpoise from Japan. Bull. Am. Mus. Nat. Hist. 30:31-51.

Arnold, P. W., and G. E. Heinsohn.

1996. Phylogenetic status of the Irrawaddy dolphin $\mathrm{Or}$ caella brevirostris (Owen in Gray): a cladistic analysis. Mem. Qld. Mus. 39:141-204.

Artedi, P.

1738. Ichthyologia: sive, opera omnia de piscibus, scilicet: bibliotheca ichthyologica. Philosophia ichthyologica. Genera piscium. Synonymia specierum. Descriptiones specierum: omia in hoc genere perfectoria, quam, antea, ulla, 104 p. Apud Conradum Wishoff, Lugduni Batavorum.

Arvy, L.

1972a. Jean-Jacques Dussumier, master mariner and cetologist (1792-1883). Invest. Cetacea 4:263-269.

1972b. The cetological gleanings of Christophe Paulin de la Poix, Compte de Freminville, naval commander (17871848). Invest. Cetacea 4:270-274.

1977. Cetology and naturalists in France at the beginning of the nineteenth century. Invest. Cetacea 8:323-339.

Barabash, I. I.

1937. Taxonomic observations on white whales. J. Mammal. 18:507-509. https://doi.org/10.2307/1374345 
Barabash, I. I., and S. K. Klumov.

1935. The Pacific form of the beluga. [In Russian.] Sea Fish. Econ. U.S.S.R. 11:24.

Beasley, I., K. M. Robertson, and P. Arnold.

2005. Description of a new dolphin, the Australian snubfin dolphin Orcaella heinsohni sp. n. (Cetacea, Delphinidae). Mar. Mamm. Sci. 21:365-400. https://doi. org/10.1111/j.1748-7692.2005.tb01239.x

Bekker, J. P., M. E. J. Bosselaers, and G. R. Heerebout.

2016. Supposedly lost syntype of the rough-toothed dolphin (Steno bredanensis (Lesson, 1828)) traced back at the Ghent University Museum. Lutra 59:65-73.

Bennett, F. D.

1840. Narrative of a whaling voyage round the globe, from the year 1833 to 1836,2 vols. Richard Bentley, London.

Berzin, A. A., and V. L. Vladimirov.

1982. Novyi vid kosatok iz Antarktiki [A new species of killer whale from the Antarctic] (S. Pearson, trans.). Priroda 6:31.

Best, P. B.

1988. The external appearance of Heaviside's dolphin, Cephalorhynchus heavisidii (Gray, 1828). Rep. Int. Whal. Comm. (special issue) 9:279-299.

Billberg, G. J.

1827. Synopsis faunae Scandinaviae, tom. 1, pars 1, Mammalia, 55 p. Ex Officina Typogr. Caroli Deleen, Holmiae, Sweden.

Blanford, W. T.

1891. The fauna of British India including Ceylon and Burma: Mammalia, 617 p. Taylor and Francis, London.

Blumenbach, J. F.

1779. Handbuch der naturgeschichte, vol. 1, 448 p. Johann Christian Dieterich, Göttingen, Germany.

Blyth, E.

1848. Report of Curator, Zoological Department. J. Asiatic Soc. Bengal 17:247-255.

1852. Report of Curator, Zoological Department. J. Asiatic Soc. Bengal 21:341-358.

1859. On the great rorqual of the Indian Ocean, with notices of other cetals, and of the syrenia or marine pachyderms. J. Asiatic Soc. Bengal 28:481-498.

Bonnaterre, P. J.

1789. Tableau encyclopédique et méthodique des trois règnes de la nature. Cétologie, 28 p., 12 plates. Pandkoucke, Paris.

Borowski, G. H.

1781. Gemeinnüzzige naturgestchichte des thierreichs, vol. 1, Text, 332 p., Plates, 38 plates. Gottlieb August Lange, Berlin and Stralsund, Germany. [The plates volume was published in 1780 , but the text volume was published in 1781.]

Braulik, G. T., F. I. Archer, U. Khan, M. Imran, R. K. Sinha, T.

A. Jefferson, and J. A. Graves.

2021. Revision of the South Asian River dolphin (genus Platanista): Ganges and Indus River dolphins are separate species. Mar. Mamm. Sci. 2021:1-38. https://doi. org/10.1111/mms.12801

Brightwell, T.

1846. Observations on a specimen of the bottle-nosed dolphin, Delphinus tursio, Fabr., taken at Great Yarmouth, October 1845. Ann. Mag. Nat. Hist. 17:21-22.
Brisson, M.-J.

1756. Le regne animal divisé en IX classes, ou, méthode contenant la division generale des animaux en IX classes: $\&$ la division particuliere des deux premieres classes, sçavoir de celle des quadrupedes \& de celle des cetacées, en ordres, sections, genres \& espéces: aux quelles on a joint une courte description de chaque espéce, avec les citations des auteurs qui en ont traité, les noms qu'ils les différentes nations, \& les noms vulgaires, 384 p. Cl. Jean-Baptiste Bauche, Paris.

1762. Regnum animale in classes IX. Distributum, sive, synopsis methodica: sistens generalem animalium distributionem in classes IX, \& duarum primarum classium, quadrupedum scilicet $\&$ cetaceorum, particularem divisionem in ordines, sectiones, genera \& species: cum brevi cujusque speciei descriptione, citationibus auctorum de iis tractantium, nominibus eis ab ipsis \& nationibus impositis, nominibusque vulgaribus, 296 p. Apud Theodorum Haak, Lugduni Batavorum.

Brookes, J.

1828. A catalogue of the anatomical and zoological museum of Joshua Brookes, Esq., F.R.S. F.L.S. \&c, 40 p. Richard Taylor, London.

Brownell, R. L., Jr.

1975. Taxonomic status of the dolphin Stenopontistes zambezicus Miranda-Ribeiro, 1936. Z. Saug. 40:173-176.

Brownell, R. L., Jr., and R. Praderi.

1985. Distribution of Commerson's dolphin, Cephalorbynchus commersonii, and the rediscovery of the type of Lagenorhynchus floweri. Sci. Rep. Whales Res. Inst. 36:153-164.

Brownell, R. L., Jr., and J. G. Mead.

1989. Taxonomic status of the delphinid (Mammalia: Cetacea) Tursio? panope Philippi, 1895. Proc. Biol. Soc. Wash. 102:532-534.

Brownell, R. L., Jr., L. T. Findley, O. Vidal, A. Robles, and N. S. Manzanilla.

1987. External morphology and pigmentation of the vaquita, Phocoena sinus (Cetacea: Mammalia). Mar. Mamm. Sci. 3:22-30. https://doi.org/10.1111/j.1748-7692. 1987.tb00149.x

Burmeister, $\mathrm{H}$.

1865a. Description of a new species of porpoise in the Museum of Buenos Ayres. Proc. Zool. Soc. Lond. 33:228-231. https://doi.org/10.1111/j.1469-7998.1865. tb02325.x

$1865 \mathrm{~b}$. Description of a new species of porpoise in the Museum of Buenos Ayres. Ann. Mag. Nat. Hist. 16:132-134.

1866. On some cetaceans. Ann. Mag. Nat. Hist. (Ser. 3) 18:99-103.

1868. On Globicephalus grayi, nov. spec. Ann. Mag. Nat. Hist. 1:52-54.

1869. Descripción de cuatro especies de delfinides de la costa Argentina del Océano Atlántico. An. Mus. Nac. Hist. Nat. Buenos Aires 1:367-442.

1872. On my so-called Globicephalus grayi. Ann. Mag. Nat. Hist.10:51-54.

Caballero, S., F. Trujillo, J. A. Vianna, H. Barrios-Garrido, M. G. Montiel, S. Beltrán-Pedreros, M. Marmontel, M. C. Santos, M. Rossi-Santos, F. R. Santos, et al.

2007. Taxonomic status of the genus Sotalia: species level ranking for "tucuxi" (Sotalia fluviatlis) and "costero" 
(Sotalia guianensis) dolphins. Mar. Mamm. Sci. 23:358386. https://doi.org/10.1111/j.1748-7692.2007.00110.x

Cabrera, A.

1957. Catalogo de los mamiferos de America del Sur. I: Metatheria-Unuiculata-Carnivora. Rev. Mus. Argent. Cienc. Nat. Bernardino Rivadavia Inst. Nac. Invest. Cienc. Nat., Cienc. Zool. 4(1-2):301-307, 309-311, 603-625.

Canto, H. J.

2014. On the taxonomic identity of the holotype of Tursio? Panope Philippi, 1895. Bol. Mus. Nac. Hist. Nat., Chile 63:51-59.

Cassin, J.

1858. United States Exploring Expedition. During the years 1838, 1839, 1840, 1841, 1842. Under the command of Charles Wilkes, U.S.N. Mammalogy and ornithology. With a folio atlas, vol. 8, bk. 1, Text, 466 p., bk. 2, Atlas, 53 plates. Lippincott and Co., Philadelphia, PA.

Charlton-Robb, K., L. Gershwin, R. Thompson, J. Austin, K. Owen, and S. McKechnie.

2011. A new dolphin species, the Burrunan dolphin Tursiops australis sp. nov., endemic to southern Australian coastal waters. PLoS ONE 6(9):e24047. https://doi. org/10.1371/journal.pone.0024047

Cope, E. D.

1865a. Second contribution to a history of the Delphinidae. Proc. Acad. Nat. Sci. Phila. 17:278-281.

1865b. A contribution to a knowledge of the Delphinidae. Proc. Acad. Nat. Sci. Phila. 17:198-204.

1866. Third contribution to the history of the Balaenidae and Delphinidae. Proc. Acad. Nat. Sci. Phila. 18:293-300.

1876. Fourth contribution to the history of the existing Cetacea. Proc. Acad. Nat. Sci. Phila. 28:129-139.

Costa, A. P. B., P. E. Rosel, F. G. Daura-Jorge, and P. C. Simões-Lopes.

2016. Offshore and coastal common bottlenose dolphins of the western South Atlantic face-to-face: what the skull and the spine can tell us. Mar. Mamm. Sci. 32:14331457. https://doi.org/10.1111/mms.12342

Costa, A. P. B., P. F. Fruet, E. R. Secchi, F. G. Daura-Jorge, P. C. Simões-Lopes, J. C. Di Tullio, and P. E. Rosel.

2021. Ecological divergence and speciation in common bottlenose dolphins in the western South Atlantic. J. Evol. Biol. 34:16-32. https://doi.org/10.1111/jeb.13575

Cunha, H. A., R. L. de Castro, E. R. Secchi, E. A. Crespo, J. Lailson-Brito, A. F. Azevedo, C. Lazoski, and A. M. Solé-Cava.

2015. Molecular and morphological differentiation of common dolphins (Delphinus sp.) in the Southwestern Atlantic: testing the two species hypothesis in sympatry. PLoS ONE 10(11):e0140251. https://doi.org/10.1371/journal. pone. 0140251

Cuvier, F.

1836. De l'histoire naturelle des cétacés, ou recueil et examen des faits dont se compose l'histoire naturelle de ces animaux, 416 p., 22 plates. Libraire Encyclopedique de Roret, Paris.

Cuvier, G.

1812. Rapport fait à la classe des sciences mathématiques et physiques, sur divers cétacés pris sur les côtes de France, principalement sur ceux qui sont échoués près de paimpol, le 7 Janvier 1812. Ann. Mus. Hist. Nat. 19:1-16.

1816. Le règne animal distribué d'après son organsation, pour servir de base à l'histoire naturelle des animaux et d'introduction à l'anatomie comparée. Les reptiles, les poissons, les mollusques et les annélides, vol. 2, 532 p. Deterville, Paris.

1823. Recherches sur les ossemans fossiles, où l'on rétablit les caractères de plusieurs animaux dont les révolutions du globe ont détruit les espèces, nouvelle édition, vol. 5, part 1, 405 p., 27 plates. G. Dufour et E. d'Ocague, Paris.

1825. Recherches sur les ossemens fossiles, où l'on rétablit les caractères de plusieurs animaux dont les révolutions du globe ont détruit les espèces, nouvelle édition, vol. 7. G. Dufour et E. d'Ocague, Paris.

1829. Le règne animal distribué d'après son organsation, pour servir de base à l'histoire naturelle des animaux et d'introduction à l'anatomie comparée, nouvelle édition, vol. 1, 584 p. Deterville, Paris.

d'Orbigny, A.

1834. Notice sur un nouveau genre de cetacé des riviéres du centre de l'Amérique méridionale. Nouv. Ann. Mus. d'Hist. Nat. 3:28-36.

d'Orbigny, A., and P. Gervais.

1847. Voyage dans l'Amérique méridionale: (le Brésil, la république orientale de l'Uruguay, la République Argentine, la Patagonie, la République du Chili, la République de Bolivia, la République du Pérou), exécuté pendant les années 1826, 1827, 1828, 1829, 1830, 1831, 1832, et 1833, vol. 4, part 2: mammifères, 32 p. P. Bertrand, Paris.

Dall, W. H.

1873. Descriptions of three new species of Cetacea, from the coast of California. Proc. Calif. Acad. Sci. 5:12-14.

1874. Catalogue of the Cetacea of the North Pacific Ocean, with osteological notes, and descriptions of some new forms. In The marine mammals of the North-western coast of North America together with an account of the American whale-fishery (C. M. Scammon, ed.), p. 281308. Manessier Publishing Co., San Francisco, CA.

Darwin, C.

1860. Journal of researches during the voyage of H.M.S. "Beagle", 2nd ed., 512 p. Collins' Clear-Type Press, London.

Desmarest, A. G.

1817. Dauphin. In Nouveau dictionnaire d'histoire naturelle, appliquée aux arts, à l'agriculture, à l'économie rurale et domestique, à la médicine, etc. par une société de naturalistes et d'agriculteurs, nouvelle édition, vol. 9, p. 146-180. Deterville, Paris.

1822. Part 2: contenant les ordres des rongeurs, des édentés, des pachydermes, des ruminans et des cétacés. In Mammalogie ou description des espèces de mammifères, p. 277-555. Mme. Veuve Agasse, Paris.

Desmarest, E.

1856. Deuxième sous-ordre. Cétacés proprement dits. Cetae. Linné. In Encyclopédie d'histoire naturelle ou traité complet de cette science: pachydermes, ruminants, édentés, cétacés, marsupiaux et monotrèmes (J. C. Chenu, ed.), p. 276-310. Marescq et Compagnie and G. Havard, Paris. 
1874. Cétacés. In Encyclopédie d'histoire naturelle ou traité complet de cette science: pachydermes, ruminants, édentés, cétacés, marsupiaux et monotrèmes (J. C. Chenu, ed.), p. 255-310. Firmin Didot et Cie, Paris.

Dieterlen, F., H. Turni, and K. Marquart.

2013. Type specimens of mammals in the collection of the Museum of Natural History Stuttgart. Stuttg. Beitr. Nat. kd. A, n.s. 6:291-303.

Duhamel du Monceau, M.

1782. Traité général de peches, et histoire des poissons qu'elles fournissent. Suite de la seconde partie, tom. 4, 73 p. Veuve Desaint, Paris.

Eschricht, D. F.

1846. Undersögelser over hvaldyrne. Femte afhandling. Finhvalernes Osteologie og Artsadskillelse. Kongelige Danske Vid. Selsk. Naturvid.og Mathem. Afh. 12:225-396.

1851. Om Gangesdelphinen. Kongelige Danske Vidensk. Selsk. Skr. 5 Raekke, Naturv. og Math. Afd. 2:345-387.

1852. On the Gangetic dolphin. Ann. Mag. Nat. Hist. 9:161-188, 279-293.

1863. Om spaekhuggeren (Delphinus orca L.). Oversigt over det Kongelige Danske Vid. Selsk. Forhandlinger 1862:65-91, 234-264. [Although usually cited as published in 1862, Eschricht's monograph on the killer whale/orca (with Reinhardt's note introducing the relevant scientific name) was actually published in 1863.]

1866. On the species on the genus Orca inhabiting the northern seas. In Recent memoirs on the Cetacea (W. H. Flower, ed.), p. 151-188. R. Hardwicke, London.

Escorza-Treviño, S., A. E. Dizon, and L. A. Pastene.

2004. Molecular analyses of the truei and dalli morphotypes of Dall's porpoise (Phocoenoides dalli). J. Mammal. 85:347-355. https://doi.org/10.1644/15451542(2004)085<0347:MAOTTA>2.0.CO;2

Fabricius, O.

1780. Fauna Groenlandica: Systematice Sistens Animalia Groenlandiae Occidentalis Hactenus Indagata, quad Nomen Specificum, Triviale, Vernaculumque: Synonyma Auctorum Plurium, Descriptionem, Locum, Victum, Generationem, Mores, Usum, Capturamque Singuli, Prout Detegendi Occasio Fuit: Maximaque Parte Secundum Proprias Observationes, p. 29-52. Ioannis Gottlob Rothe, Copenhagen, Denmark.

Fischer, J. B.

1829. Synopsis Mammalium, 752 p. Suntibus J. G. Cottae, Stuttgardtiae, Germany.

Fischer, P.

1876. Sur une espèce de cétacé (Orca antarctica) observée durant le voyage de l'Astrolabe et de la Zélée dans les parages des Îles Powell et des Nouvelles-Shetland méridionales. J. Zool. 5:146-151.

1881. Cétacés du sud-ouest de la France. Actes Soc. Linn. Bordx. 35:1-220.

Fisher, R. D., and C. A. Ludwig.

2016. Catalog of type specimens of recent mammals: Order Carnivorna, Perrisodactyla, Artiodactyla, and Cetacea in the National Museum of Natural History. Smithson. Contrib. Zool. 646, 112 p.

Fitzinger, L. J.

1860. Wissenschaftlich-populäre naturgeschichte der säugethiere in ihren sämmtlichen hauptformen: nebst einer einleitung in die naturgeschichte uberhaupt und in die Lehre von den Thieren insbesondere, vol. 6, 364 p. Aus der Kaiserlich-königlichen hof- und staatsdrucherei, Wien (Vienna), Austria.

Fleming, J.

1828. A history of British animals: exhibiting the descriptive characters and systematical arrangement of the genera and species of quadrupeds, birds, reptiles, fishes, mollusca, and radiata of the United Kingdom; including the indigenous, extirpated, and extinct kinds, together with periodical and occasional visitants, 565 p. Bell \& Bradfute, Edinburgh, Scotland.

Flower, W. H.

1864. On a new species of Grampus (Orca meridionalis) from Tasmania. Proc. Zool. Soc. Lond. 32:420-426. https:// doi.org/10.1111/j.1469-7998.1864.tb00409.x

1865. Note on Pseudorca meridionalis. Proc. Zool. Soc. Lond. 33:470-471. https://doi.org/10.1111/j.1469-7998.1865. tb02374.x

1870. Description of the skeleton of the Chinese white dolphin (Delphinus sinensis, Osbeck). Trans. Zool. Soc. Lond. 7:151-160.

1884. On the characters and divisions of the family Delphinidae. Proc. Zool. Soc. Lond. 1883:466-513. [Although the date imprinted on the header of the paper is $20 \mathrm{No}-$ vember 1883, a handwritten note by the author (Flower) on a reprint sent to Agassiz indicates that it was actually published on 1 April 1884.]

Forster, J. R.

1844. Descriptiones animalium quae in itinere ad maris australis terras per annos 1772, 1773 et 1774 suscepto collegit, 424 p. Ex Officina academica, Berolini.

Fraser, F. C.

1950. Description of a dolphin Stenella frontalis (Cuvier) from the coast of French Equatorial Africa. In Atlantide report 1 . Scientific results of the Danish expedition to the coasts of tropical West Africa 1945-1946, p. 61-84. Danish Science Press, Copenhagen, Denmark.

1956. A new Sarawak dolphin. Sarawak Mus. J., 7(8, n.s.):478-503.

1966. Comments on the Delphinoidea. In Whales, dolphins, and porpoises (K. S. Norris, ed.), p. 7-31. Univ. Calif. Press, Berkeley, CA.

Fraser, F. C., and B. A. Noble.

1968. Skull of Lagenorhynchus cruciger from Livingston Island, South Shetland Islands. Br. Antarct. Surv. Bull. 15:29-38.

Freminville, M.

1812. Notice sur espèce de dauphin observée dans la mer glaciale. Nouv. Bull. Sci., Soc. Philom., Paris 3(56):71.

Galatius, A., and C. C. Kinze.

2016. Lagenorhynchus albirostris (Cetacea: Delphinidae). Mammal. Species 48:35-47. https://doi.org/10.1093/ mspecies/sew003

Gallardo, A.

1917. Sobre el tipo de la Phocaena spinipinnis Burmeister. Physis, Buenos Aires 3:83-84.

Gaskin, D. E.

1972. Whales, dolphins, and seals, with special reference to the New Zealand region, 200 p. Heineman Educational Books, London. 
Gervais, P.

1853. Remarques sur les mammifères marins qui frequentent les côtes de la France et plus particulièrement sur une nouvelle espèce de dauphins propre à la Méditerranée. Bull. Soc. Cent. Agric. Comices Agric. Dép. l'Hérault, Montpelier 40:140-156.

1855. Description des trois espèces de dauphins qui vivent dans la region du haut Amazone. In F. de Castelnau, Expédition dans les parties centrales de l'Amérique du Sud, de Rio de Janeiro a Lima, et de Lima au Para, 7, Zoologie, p. 89-94. P. Bertrand, Paris.

Gervais, P., and A. d'Orbigny.

1844. Mammalogie. Bull. Soc. Philom., Paris 1844:38-40.

Gesner, C.

1558. Historiæ animalivm liber IV. Qui est de piscium \& aquatilium animantium natura. Cum iconibus singulorum ad viuum expressis ferè omnibus 712,1052 p. In Bibliopolio Andrae Cambieri, Francofurti.

Giglioli, E. H.

1870. Mammiferi. In Note Intorno Alla Distribuzione della Fauna Vertebrata Nell'Oceano Prese Durante un Viaggio Intorno al Globo 1865-68, p. 71-82. G. Civelli, Firenze.

1874. I Cetacei Osservati Durante IL Viaggio Intorno Al Globo Della R. Pirocorvetta Magenta 1865-68, 105 p. Stamperia della R. Univ., Napoli, Italy.

1882. Note intorno un nuovo Cetaceo nel Mediteraneo da riferersi probabilemente al genere Pseudorca. Zool. Anz. 5:288-290.

Gill, T.

1865. On two species of Delphinidae, from California, in the Smithsonian Institution. Proc. Acad. Nat. Sci. Phila. 17:177-178.

Gloger, C. W. L.

1841. Gemeinnütziges hand- und hilfsbuch der naturgeschichte. Für gebildete leser aller stände, besonders für die reifere Jugend und ihre lehrer, vol. 1, 495 p. Berlag von Aug, Schulz and Comp., Breslau.

Goodall, R. N. P.

1986. On the identity of Tursio chiloensis Philippi 1900. Mar. Mamm. Sci. 2:230-232. https://doi.org/10.1111/j.17487692.1986.tb00044.x

Goodall, R. N. P., K. S. Norris, A. R. Galeazzi, J. A. Oporto, and I. S. Cameron.

1988a. On the Chilean dolphin, Cephalorhynchus eutropia (Gray, 1846). Rep. Int. Whal. Comm. (special issue) 9:197-257.

Goodall, R. N. P., A. P. Sobral, M. Labal de Vinuesa, and I. S. Cameron.

1988b. On Phocoena obtusata, with a comparison of certain diagnostic characters in South American phocoenids and the genus Cephalorhynchus. Rep. Int. Whal. Comm. (special issue) 9:259-276.

Goodall, R. N. P., K. S. Norris, W. E. Schevill, F. Fraga, R. Praderi, M. A. Iñiguez, Jr., and J. C. de Haro.

1997. Review and update on the biology of Peale's dolphin, Lagenorhynchus australis. Rep. Int. Whal. Comm. 47:777-796.

Goodwin, G. G.

1953. Catalogue of the type specimens of recent mammals in the American Museum of Natural History. Bull. Am. Mus. Nat. Hist. 102:207-411.
Gray, J. E.

1821. On the natural arrangement of vertebrose animals. Lond. Med. Repos. 15:296-310.

1827. Description of the skulls of two apparently undescribed species of dolphins, which are in the British Museum. Philos. Mag. 2:375-376. https://doi. org/10.1080/14786442708674500

1828. Spicilegia zoologica; or original figures and short systematic descriptions of new and unfigured animals, $5 \mathrm{p}$. Treuttel, Wurtz and Co., London.

1843a. List of the specimens of Mammalia in the collection of the British Museum, 216 p. Order of the Trustees, London.

1843b. List of Mammalia hitherto recorded as found in New Zealand. In Travels in New Zealand with contributions to the geography, geology, botany, and natural history of that country, vol. 2, (E. Dieffenbach, ed.), p. 181-185. J. Murray, London.

1846. On the cetaceous animals. In The zoology of the voyage of H.M.S. Erebus and Terror, under the command of Captain Sir James Clark Ross, R.N., FR.S., during the years 1839 to 1843 . Volume 1: Mammalia, birds (J. Richardson and J. E. Gray, eds.), p. 13-53. E. W. Janson, London.

1847. List of the osteological specimens in the collection of the British Museum, 147 p. Order of the Trustees, London.

1849. Descriptions of three new species of Delphinidae. Proc. Zool. Soc. Lond. 17:1-3.

1850. Catalogue of the specimens of Mammalia in the collection of the British Museum. Part 1, Cetacea, 153 p. Order of the Trustees, London.

1856. Description of a new species of dolphin (Steno) from the upper parts of the River Amazon. Ann. Mag. Nat. Hist. 18:157-159. https://doi. org/10.1080/00222935608697602

1861. Notice of a new species of pilot-whale (Globicephalus), from the coast of Dorsetshire. Proc. Zool. Soc. Lond. 1861:309-313.

1862. Notice of a new species of dolphin (Delphinus catalania), discovered in North Australia by Mr. John Macgillivray. Proc. Zool. Soc. Lond. 1862:143-145.

1864. On the Cetacea which have been observed in the seas surrounding the British Islands. Proc. Zool. Soc. Lond. 1864:195-248.

1865a. Notices of a new genus of delphinoid whales from the Cape of Good Hope, and of other cetaceans from the same seas. Proc. Zool. Soc. Lond. 1865:522-529.

1865 b. Notice of a new species of porpoise (Phocaena tuberculifera) inhabiting the Mouth of the Thames. Proc. Zool. Soc. Lond. 1865:318-321.

1866a. Catalogue of seals and whales in the British $\mathrm{Mu}-$ seum, 2nd ed., 402 p. Order of the Trustees, London.

$1866 \mathrm{~b}$. Notes on the skulls of dolphins, or bottlenose whales, in the British Museum. Proc. Zool. Soc. Lond. 1866:211-216.

1866c. Description of three species of dolphins in the Free Museum at Liverpool. Proc. Zool. Soc. Lond. 1865:735-739.

1868a. Synopsis of the species of whales and dolphins in the collection of the British Museum, 10 p., 37 plates. Bernard Quartitch, London. 
1868b. Notice of Clymene similis, a new dolphin sent from the Cape by Mr. Layard. Proc. Zool. Soc. Lond. 1868:146-149.

1870. Notes on the skulls of the genus Orca in the British Museum, and notice of a specimen of the genus from the Seychelles. Proc. Zool. Soc. Lond. 1870:70-77.

1871. Supplement to the catalogue of seals and whales in the British Museum, 103 p. Order of the Trustees, London.

1874. Description of the skull of a new species of dolphin (Feresa attenuata). Ann. Mag. Nat. Hist. (Ser. 4) 14:238239. https://doi.org/10.1080/00222937408680959

1875. Feresa attenuata. J. Mus. Godeffroy 8:184.

Grill, J. W.

1858. Zoologiska Anteckningar under en resa i södra delarne af Caplandet åren 1853-1855; af J. F. Victorin. Ur den aflidnes papper samlade och ordade af J. W. Grill. Kongliga Svenska Vetenskaps-Akademiens Handlingar 2(10):1-62.

Gunnerus, J. E.

1768. Om stour-vagnen eller de Gamles Orca. Det Kongelige Norske Videnskabers Selskabs Skrifter 4:99-112.

Hamilton, R.

1837. The naturalist's library: Mammalia, whales, etc, vol. 26, 264 p. W. H. Lizars and H. G. Bohn, London. [Although an 1852 reprint/facsimile edition of this book is often cited, the book was originally published in 1837.]

Harlan, R.

1827. Description of a new species of Grampus, (Delphinus, Cuv.) inhabiting the coast of New England. J. Acad. Nat. Sci. Phila. 6:51-53. [Although the imprint date on the journal title page is 1829 , the date 1827 imprinted on the paper is considered the correct publication date for this article.]

Hector, J.

1872. On the New-Zealand bottlenose (Lagenorhynchus clanculus, Gray). Ann. Mag. Nat. Hist. 9:436-438. https://doi.org/10.1080/00222937208696613

1873. On the whales and dolphins of the New Zealand seas. Trans. N. Z. Inst. 5:154-170.

Heintzelman, D. S.

1981. A world guide to whales, dolphins, and porpoises, 156 p. Winchester Press, Tulsa, OK.

Hemprich, C. G., and W. F. Ehrenberg.

1832. Symbolae Physicae. Mammalia, 2. Herpestes leucurus H. et E., 6 p., unpaginated. Berolini Ex Officina Academica, Berlin, Germany. [This work was published between the years of 1828 and 1845. Description of Tursiops aduncus in footnote by Ehrenberg on last page of unpaginated fascicle headed Herpestes leucurus $\mathrm{H}$. et E. Two versions of this work were published in 1832, one with and one without the footnote.]

Hershkovitz, P.

1961. On the nomenclature of certain whales. Fieldiana Zool. 39:547-565.

1963. Notes on the South American dolphins of the genera, Inia, Sotalia, and Tursiops. J. Mammal. 44:98-103. https://doi.org/10.2307/1377172

1966. Catalog of living whales. Bull. U.S. Natl. Mus. 246, $259 \mathrm{p}$.
Heyning, J. E., and W. F. Perrin.

1994. Evidence for two species of common dolphins (genus Delphinus) from the eastern North Pacific. Nat. Hist. Mus. Los Ang. Cty., Contrib. Sci. 442, 35 p.

Hohl, L. S. L., F. L. Sicuro, J. C. Wickert, I. B. Moreno, O. Rocha-Barbosa, and A. S. Barreto.

2020. Skull morphology of bottlenose dolphins from different ocean populations with emphasis on South America. J. Morphol. 281:564-577. https://doi.org/10.1002/ jmor.21121

Hrbek, T., V. M. F. da Silva, N. Dutra, W. Gravena, A. R. Martin, and I. P. Farias.

2014. A new species of river dolphin from Brazil or: how little do we know of our biodiversity. PLoS ONE 9(1):e83623. https://doi.org/10.1371/journal. pone. 0083623

Huang, W., and B. Fu.

1984. A new species of genus Sousa. In Collected abstracts of the fiftieth anniversary of the founding of China $\mathrm{Zo}$ ological Society and eleventh representative conference (Anonymous, ed.), p. 446. China Zool. Soc., Shanghai, China.

Hunter, J.

1787. Observations on the structure and oeconomy of whales. By John Hunter, Esq. F. R. S. communicated by Sir Joseph Banks, Bart. F. R. S. Philos. Trans. R. Soc. Lond. 77:371-450. https://doi.org/10.1098/ rstl.1787.0038

ICZN (International Commission on Zoological Nomenclature). 1991. Opinion 1659. Steno attenuatus (Gray), 1846 (currently Stenella attenuata; Mammalia, Cetacea): Specific name conserved. Bull. Zool. Nomencl. 48:277-278.

1999. The International Code of Zoological Nomenclature, 4th ed., 306 p. Int. Trust Zool. Nomencl., Nat. Hist. Mus., London.

Iredale, T., and E. L. G. Troughton.

1933. The correct generic names for the grampus or killer whale, and the so called grampus or Risso's dolphin. Rec. Aust. Mus. 19:28-36. https://doi.org/10.3853 /j.0067-1975.19.1933.689

1934. A check-list of the mammals recorded from Australia. Aust. Mus. Mem. 6:1-122. https://doi.org/10.3853 /j.0067-1967.6.1934.516

Jacquinot, H., and J. Pucheran.

1853. Mammiferes et oiseaux. In Voyage au pole sud et dans l'Océanie sur les corvettes L'Astrolabe et la Zélée, Zoologie, vol. 3, part 1 (J. Hombron and H. Jacquinot, eds.), p. 7-166. Gide et J. Baudry, Paris.

Jefferson, T. A.

1996. Morphology of the Clymene dolphin (Stenella clymene) in the northern Gulf of Mexico. Aquat. Mamm. 22:35-43.

2002. Preliminary analysis of geographic variation in cranial morphometrics of the finless porpoise (Neophocaena phocaenoides). Raffles Bull. Zool., Suppl. 10:3-14.

2021. Proposal to retain the scientific names of five species of small cetaceans (Delphinapterus leucas, Tursiops truncatus, Lissodelphis borealis, Cephalorhynchus eutropia, and Inia geoffrensis) by designating their unused senior synonyms as nomina oblita. Aquatic Mammals 47(3):257-267. 
Jefferson, T. A., and L. Karczmarski.

2001. Sousa chinensis. Mammal. Species 655:1-9. https:// doi.org/10.2307/0.655.1

Jefferson, T. A., and K. Van Waerebeek.

2002. The taxonomic status of the nominal dolphin species Delphinus tropicalis van Bree, 1971. Mar. Mamm. Sci. 18:787-818. https://doi.org/10.1111/j.1748-7692.2002. tb01074.x

2004. Geographic variation in skull morphology of humpback dolphins (Sousa spp.). Aquat. Mamm. 30:3-17. https://doi.org/10.1578/AM.30.1.2004.3

Jefferson, T. A., and B. E. Curry.

2003. Stenella clymene. Mammal. Species 726:1-5. https:// doi.org/10.1644/726

Jefferson, T. A., and J. Y. Wang.

2011. Revision of the taxonomy of finless porpoises (genus Neophocaena): the existence of two species. J. Mar. Anim. Ecol. 4(1):3-16.

Jefferson, T. A., and H. C. Rosenbaum.

2014. Taxonomic revision of the humpback dolphins (Sousa spp.), and description of a new species from Australia. Mar. Mamm. Sci. 30:1494-1541. https://doi. org/10.1111/mms.12152

Jefferson, T. A., S. K. Hung, K. M. Robertson, and F. I. Archer. 2012. Life history of the Indo-Pacific humpback dolphin in the Pearl River Estuary, southern China. Mar. Mamm. Sci. 28:84-104. https://doi.org/10.1111/j.1748-7692. 2010.00462.x

Jones, J. K., and R. L. Packard.

1956. Feresa intermedia (Gray) preoccupied. Proc. Biol. Soc. Wash. 69:167-168.

Jones, J. K., D. C. Carter, H. H. Genoways, R. S. Hoffman, D.

W. Rice, and C. Jones.

1986. Revised checklist of North American mammals north of Mexico, 1986. Occas. Pap., Mus. Texas Tech. Univ. 107:1-22.

Kellogg, R.

1941. On the identity of the porpoise Sagmatias amblodon. Field Mus. Nat. Hist., Zool. Ser. 27:293-311.

Kerr, R.

1792. The animal kingdom, or zoological system, of the celebrated Sir Charles Linnaeus. Class 1. Mammalia, 644 p. A. Strahan and T. Cadwell, Edinburgh.

Kinze, C. C.

2000. Rehabilitation of Platanista gangetica (Lebeck, 1801) as the valid scientific name of the Ganges dolphin. Zool. Meded. 74:193-203.

2011. Daniel Frederik Eschricht (1798-1863), his investigations on cetaceans and the nordic whales in particular. Hist.-meereskund. Jahrb. (Hist. Oceanogr. Yearb.) 17:65-96.

2015. Comments on Sousa nomenclature: a response to Jefferson and Rosenbaum. Mar. Mamm. Sci. 31:833-836. https://doi.org/10.1111/mms.12223

2018. A case for Tursiops tursio (Gunnerus, 1768). Lutra 61:189-197.

Klein, J. T.

1741. Historiae Piscium Naturalis Promovendae. Missus Secondus de Piscibus Per Pulmones Spirantibus ad Iustum Numerum et Ordinem Redigendis, 39 p., 4 plates. Litteris Schreiberianis, Gedani, Germany.
Klumov, S. K.

1935. A new form of the beluga [In Russian]. Sea Fish. Econ. U.S.S.R. 7:26-28.

Koopman, K. F.

1976. Catalog of type specimens of recent mammals in the Academy of Natural Sciences at Philadelphia. Proc. Acad. Nat. Sci. Phila. 128:1-24.

Kükenthal, W.

1892. Sotalia teuszii n. sp. ein pflanzenfressender (?) delphin aus Kamerun. Zool. Jahrb. Abt. Syst. Oekol. Geogr. Tiere. 6:442-446.

Kurihara, N., and S. Oda.

2007. Cranial variation in bottlenose dolphins Tursiops spp. from the Indian and western Pacific Oceans: additional evidence for two species. Acta Theriologica 52:403-418. https://doi.org/10.1007/BF03194238

Lacépède, B. G. E.

1804. Histoire naturelle des cétacées, 329 p. Plassan, Paris. 1818. Note sur des cétacées des mers voisines du Japon. Mem. Mus. Natl. Hist. Nat. 4:467-475.

Lafont, A.

1868. Note pour servir à la faune de la Giron, contenant la liste des animaux marins dont la présence à Arachon a été constatée pendant les années 1867 et 1868. Actes Soc. Linn. Bordx. 26:518-531.

Lahille, F.

1899. Ensayo sobre la distribución geográfica de los mamiferos en la República Argentina. Primera Reun. Congr. Cient. Latino Am. 3:165-206.

1908. Nota sobre un delfin (Tursiops gephyreus Lah.). An. Mus. Nac. Hist. Nat. Buenos Aires (Ser. 3) 9:347-365.

1912. Nota preliminar sobre una nueva especie de marsopa del Rio de la Plata (Phoocena dioptrica). An. Mus. Nac. Hist. Nat. Buenos Aires 23:269-278.

Lebeck, H. J.

1801. Delphinus gangeticus beschrieben von Herrn Heinrich Julius Lebeck. Der Ges. Nat. Forsch. Fruende zu Berlin 3:280-282.

Lesson, R. P.

1826. Indication de quelques cétacés nouveaux observés dans le voyage autour du monde de la Corvette La Coquille. Bull. Sci. Nat. Geol. 7:373-374.

1827. Manuel de mammalogie, ou histoire naturelle des mammifères, 442 p. J. B. Bailliere et Fils, Paris.

1828. Histoire naturelle générale et particulière des mammifères et des oiseaux décoverts depuis la mort de buffon. Volume 1: Cétacés, 442 p. Pourrat Frères, Paris.

1836. Histoire naturelle générale et particulière des mammifères et des oiseaux. Volume 10: oiseaux et mammifères, 414 p. Pourrat Frères, Paris.

1838. Livre 11: les mammifères cétacés. In Compléments de Buffon, vol. 1, p. 555-660. P. Pouttat Freres, Paris.

1841. Catalogue d'une faune du département de la Charente-Inférieure. Actes Soc. Linn. Bordeaux 12:1-66.

Lesson, R. P., and P. Garnot.

1827. Observations générales sur quelques cétacées. In Voyage autour du monde, éxecuté par ordre du Roi, sur la corvette de Sa Majesté, la Coquille, pendant les années 1822, 1823, 1824 et 1825. Zoologie, vol. 1, part 1 (R. P. Lesson, and P. Garnot, eds.), p. 177-186. Arthus Bertrand, Paris. [Tome Premier, 1re partie, p. 49-216 published in 1827, not 1826.] 
Lillie, D. G.

1915. Cetacea. British Antarctic ("Terra Nova") Expedition, 1910. Nat. Hist. Rep., Zool. 1:85-124.

Lilljeborg, W.

1861. Öfversigt af de inom Skandinavien (Sverige och Norrige) anträffade Hvalartade Däggdjur (Cetacea), 80 p. Upsala Univ. Arsskrift, Sweden.

1866. Synopsis of the cetaceous Mammalia of Scandinavia (Sweden and Norway). In Recent memoirs on the Cetacea (W. H. Flower, ed.), p. 219-312. R. Hardwicke, London.

Linnaeus, C.

1758. Systema naturae per regna tria naturae, secumdum classes, ordines, genera, species, cum characteribus, differentiis, stnontmis, locis, (10th revised ed.), vol. 1, 824 p. Holmiae, Laurtenii Salvii.

Loche, G. G.

1860. Description de deux nouvelles espèces du genre dauphin. Rev. Mag. Zool. (Ser. 2) 12:473-479.

Lönnberg, E.

1934. Prodelphinus graffmani n. sp. a new dolphin, from the Pacific coast of Mexico. Arkiv fur Zool. 26A:1-11.

Lütken, C. F.

1887. Kritiske studier over nogle tandhvaler af slaegterne Tursiops, Orca og Lagenorhynchus. Danske Vidensk. Selsk. Skr. (Ser. 6) 6:337-397.

1889. Spolia Atlantica. Bidrag til kundskab de tre pelagiske tanhvalslaegter Steno, Delphinus og Prodelphinus. Danske Vidensk. Selsk. Skr. 6:61.

Lydekker, R.

1901. Notice of an apparently new estuarine dolphin from Borneo. Proc. Zool. Soc. Lond. 1:88-91.

1903. Notes on the Trivandrum cetaceans. J. Bombay Nat. Hist. Soc. 15:40-41.

1904. On two dolphins from Madras. J. Bombay Nat. Hist. Soc. 15:408-414. [Actual publication is 1904.]

1909. On an Indian dolphin and porpoise. Proc. Zool. Soc. Lond. 1908:802-808.

Lyngbye, H. C.

1826. Om grindefangsten paa Færøerne, tilligemed bidrag til grindens naturhistorie. Tidsskr. Nat. 1826:204-232.

Ma, H., K. Stewart, S. Lougheed, J. Zheng, Y. Wang, and J. Zhao.

2016. Characterization, optimization, and validation of environmental DNA (eDNA) markers to detect an endangered aquatic mammal. Conserv. Genet. Resour. 8:561568. https://doi.org/10.1007/s12686-016-0597-9

Malm, A. W.

1871. Hvaldjur i sveriges museer, år 1869. Kongliga Svenska Vetenskaps-Akademiens Handlingar, vol. 9, no. 2, 104 p., 6 plates. P. A. Norstedt \& Söner, Stockholm, Sweden.

Marelli, C. A.

1922. Résultados de la primera expedición a Tierra del Fuego (1921). Phocaena stornii sp. n. una especie de marsopa del mar austral Argentino. An. Soc. Cient. Argentina 94:229-240.
McGowen, M. R., G. Tsagkogeorga, S. Álvarez-Carretero, M. dos Reis, M. Struebig, R. Deaville, P. D. Jepson, S. Jarman, A. Polanowski, P. A. Morin, et al.

2020. Phylogenomic resolution of the cetacean tree of life using target sequence capture. Syst. Biol. 69:479-501. https://doi.org/10.1093/sysbio/syz068

Melville, R. V.

1977. Opinion 1067. Suppression of Delphinus pernettensis de Blainville, 1817 and Delphinus pernettyi Desmarest, 1820 (Cetacea). Bull. Zool. Nomencl. 33:157-158.

Meyen, F. J. F.

1833. Beiträge zur zoologie, gesammelt auf einer reise um die erde. Verh. Kaiserlichen-Carolinischen Akad. Nat. 16:549-610.

Mikhalev, Y. A., M. V. Ivashin, V. P. Savusin, and F. E. Zelemaya.

1981. The distribution and biology of killer whales in the Southern Hemisphere. Rep. Int. Whal. Comm. 31:551-566.

Miller, G. S., Jr.

1918. A new river-dolphin from China. Smithson. Misc. Coll. 68(9):1-12.

Miranda-Ribeiro, A. de

1936. Cetological notes (The genera: "Steno", "Sotalia" and "Stenopontistes"). Bol. Mus. Nac. Rio de Janiero $12: 25-46$.

Mitchell, E.

1985. Relationships of killer whale (Orcinus orca) within Delphinidae. In Sixth biennial conference on the biology of marine mammals, abstracts; Vancouver, 22-26 November, p. 56. Soc. Mar. Mammol., Lawrence, KS.

Montagu, G.

1821. Description of species of Delphinus, which appears to be new. Mem. Wernerian Nat. Hist. Soc. 3:75-82.

Moreno, F. P.

1892. Noticias sobre algunos cetáceos fósiles y actuales de la República Argentina. Rev. Mus. La Plata 3:383-392.

Mörzer Bruyns, W. F. J.

1971. Field guide of whales and dolphins, 258 p. Uitgeverij Tor, Amsterdam, Netherlands.

Moura, A. E., K. Shreves, M. Pilot, K. R. Andrews, D. M. Moore, T. Kishida, L. Möller, A. Natoli, S. Gaspari, M. McGowen, et al.

2020. Phylogenomics of the genus Tursiops and closely related Delphininae reveals extensive reticulation among lineages and provides inference about eco-evolutionary drivers. Mol. Phylogen. Evol. 146:106756. https://doi. org/10.1016/j.ympev.2020.106756

Müller, O. F.

1776. Zoologiae Danicae prodromus, seu Animalium Daniae et Norvegiae indigenarum characteres, nomina, et symonyma imprimis popularium, 282 p. Havniae, Typis Hallageriis, Havniæ (Copenhagen), Denmark.

Murray, J. A.

1884. A contribution to the knowledge of the marine fauna of Kurrachee. Ann. Mag. Nat. Hist. 13:348-352.

Newcomer, M. W., T. A. Jefferson, and R. L. Brownell, Jr. 1996. Lissodelphis peronii. Mammal. Species 531:1-5.

Nilsson, S.

1847. Skandinavisk fauna. Volume 1: Daggdjuren, 656 p. C. W. K. Gleerups, Lund, Sweden. 
Nishiwaki, M., and K. S. Norris.

1966. A new genus, Peponocephala, for the odontocete cetacean species Electra electra. Sci. Rep. Whales Res. Inst. 20:95-100.

Norman, J. R., and F. C. Fraser.

1937. Giant fishes, whales and dolphins, 361 p. Putnam, London.

Norris, K. S., and W. N. McFarland.

1958. A new harbor porpoise of the genus Phocoena from the Gulf of California. J. Mammal. 39:22-39. https://doi. org/10.2307/1376606

Olivares, A. I., R. Bastida, M. C. Loza, A. C. Rodríguez, J. B.

Desojo, L. H. Soibelzon, and H. López.

2016. Catalogue of marine mammals of the mammalogical collection of the Museo de La Plata, Argentina. Rev. Mus. La Plata 1:57-82.

Oliver, W. R. B.

1922. A review of the Cetacea of the New Zealand seas. Proc. Zool. Soc. Lond. 92:557-585. https://doi. org/10.1111/j.1096-3642.1922.tb02157.x

Osbeck, P.

1765. Reise Nach Ostindien und China, 552 p. Johann Christian Koppe, Rostock, Germany.

1771. A voyage to China and the East Indies, together with a voyage to Suratte, and an account of the Chinese husbandry, vol. 2 (J. R. Forster, trans.), 367 p. Benjamin White, London.

Owen, R.

1846. A history of British fossil mammals, and birds, 560 p. John van Voorst, London.

1853. Descriptive catalogue of the osteological series contained in the Museum of the Royal College of Surgeons of England. Volume 2: Mammalia Placentalia, p. 351914. Taylor and Francis, London.

1866. On some Indian Cetacea collected by Walter Elliot, Esq. Trans. Zool. Soc. Lond. 6:17-47. https://doi. org/10.1111/j.1096-3642.1866.tb00570.x

Pallas, P. S.

1776. Reise durch verschiedene Provinzen des Rußischen Reichs, vol. 3, bk. 1, p. 1-454, bk. 2, p. 455-760. Kayserliche Academie der Wissenschaften, St. Petersburg.

1778. Reise durch verschiedene Provinzen des Rußischen Reichs in einem ausfuhrlichen auszuge, 635 p. Fleischer, Frankfurt, Germany.

1811. Zoographia Rosso-Asiatica : sistens omnium animalium in extenso Imperio Rossico, et adjacentibus maribus observatorum recensionem, domicilia, mores et descriptiones, anatomen atque icones plurimorum, vol. 1, p. 271-296. In officina Caes. Acadamiae Scientiarum Impress, Petropoli. [The original publication date is 1811, the 1831 version is a reprint.]

Palmer, T. S.

1899. Notes on three genera of dolphins. Proc. Biol. Soc. Wash. 13:23-24.

Parnaby, H. E., S. Ingleby, and A. Divljan.

2017. Type specimens of non-fossil mammals in the Australian Museum, Sydney. Rec. Aust. Mus. 69:277-420.

Peale, T. R.

1849. United States Exploring Expedition. During the years 1838, 1839, 1840, 1841, 1842. Under the command of Charles Wilkes, U.S.N. Volume 8: Mammalia and orni- thology, 338 p. C. Sherman, Philadelphia. [Although imprinted with 1848 , the actual publication date is 1849 .]

Perez Canto, C.

1896. Description de deux nouveaux cétacés de la côte du Chili. Actes Soc. Sci. Chili 5:227-229. [Although the date imprinted at the end of the paper is 14 October 1895, the date imprinted on the journal title page is 4 April 1896.]

Pernety, A. J.

1769. Journal historique d'un voyage fait aux Îles Malouines en $1763 \& 1764$, pour les reconnoître \& y former un établissement; et de deux voyages au Détroit de Magellan, avec une rélation sur les Patagons, vol. 2, 386 p. Etienne de Bourdeaux, Berlin, Germany.

1771. The history of a voyage to the Malouine (or Falkland) Islands made in 1763 and 1764, under the command of M. de Bougainville, in order to form a settlement there: and of two voyages to the Streights of Magellan, with an account of the Patagonians: translated from Dom Pernety's Historical Journal written in French, 294 p. T. Jefferys, London.

Perrin, W. F.

1975. Variation of spotted and spinner porpoise (genus Stenella) in the eastern Pacific and Hawaii. Bull. Scripps Inst. Oceanogr. Univ. Calif. 21:1-206.

1998. Stenella longirostris. Mammal. Species 599:1-7.

2009. Species. In Encyclopedia of marine mammals, 2nd ed. (W. F. Perrin, B. Würsig, and J. G. M. Thewissen, eds.), p. 1084-1087. Academic Press, Burlington, MA.

Perrin, W. F., and J. W. Gilpatrick.

1994. Spinner dolphin Stenella longirostris (Gray, 1828). In Handbook of marine mammals. Volume 5: the first book of dolphins (S. H. Ridgway and R. Harrison, eds.), p. 99-128. Academic Press, London.

Perrin, W. F., P. B. Best, W. H. Dawbin, K. C. Balcomb, R. Gambell, and G. J. B. Ross.

1973. Rediscovery of Fraser's dolphin Lagenodelphis hosei. Nature 241:345-350. https://doi.org/10.1038/ $241345 \mathrm{a} 0$

Perrin, W. F., E. D. Mitchell, J. G. Mead, D. K. Caldwell, M. C. Caldwell, P. J. H. van Bree, and W. H. Dawbin.

1987. Revision of the spotted dolphins, Stenella spp. Mar. Mamm. Sci. 3:99-170. https://doi. org/10.1111/j.1748-7692.1987.tb00158.x

Perrin, W. F., M. L. L. Dolar, and D. Robineau.

1999. Spinner dolphins (Stenella longirostris) of the western Pacific and southeast Asia: pelagic and shallow-water forms. Mar. Mamm. Sci. 15:1029-1053. https://doi. org/10.1111/j.1748-7692.1999.tb00876.x

Perrin, W. F., G. E. Zubtsova, and A. A. Kuz'min.

2004. Partial catalog of cetacean osteological specimens in Russian museums. NOAA Tech. Memo. NMFS-SWFSC 364, $26 \mathrm{p}$.

Perrin, W. F., K. M. Robertson, P. J. H. van Bree, and J. G. Mead.

2007a. Cranial description and genetic identity of the holotype specimen of Tursiops aduncus (Ehrenberg, 1832). Mar. Mamm. Sci. 23:343-357. https://doi.org/10.1111/j. 1748-7692.2007.00119.x 
Perrin, W. F., M. T. Aquino, M. L. L. Dolar, and M. N. R. Alava.

2007b. External appearance of the dwarf spinner dolphin Stenella longirostris roseiventris. Mar. Mamm. Sci. 23:464-467. https://doi. org/10.1111/j.1748-7692.2007.00117.x

Perrin, W. F., P. E. Rosel, and F. Cipriano.

2013. How to contend with paraphyly in the taxonomy of the delphinine cetaceans? Mar. Mamm. Sci. 29:567-588. https://doi.org/10.1111/mms.12051

Peters, W.

1877. Mittheilung uber die von S. M. S. Gazelle gesammelten säugethiere aus den abtheilungen de nager, hufthiere, sirenen, cetaceen und beutelehiere. Monatsberichte der Königlichen Preussische Akademie des Wissenschaften $\mathrm{zu}$ Berlin 1876:355-366. [Although the imprint date is 1876 , the correct publication date is 1877.$]$

Philbrick, N.

2003. Sea of glory: America's voyage of discovery, the U.S. Exploring Expedition, 1838-1842, 452 p. Viking Press, New York.

Philippi, R. A.

1893. Los delfines de la punta austral de la América del Sur. An. Mus Nac. Chile, Zool., 6:5-17.

1895. Los delphines Chilenos. An. Univ. Chile, Santiago 90:281-285.

1896. Los cráneos de los delfines Chilenos. An. Mus. Nac. Chile, Zool. 12:4-18.

1900. Contribucion a la osteolojía de Grypotherium domesticum Roth i un nuevo delfin, 12 p. Imprenta Cervantes, Santiago, Chile.

1901. Tursio? chiloensis Ph. eine neue Art chilenischer delphine. Arch. Naturgesch. 1:276-278.

Pichler, F. B., and C. Olavarria B.

2001. Resolving Chilean dolphin (Cephalorhynchus eutropia, Gray 1846) synonymy by sequencing DNA extracted from teeth of museum specimens. Rev. Biol. Mar. Oceanogr. 36:117-121. https://doi.org/10.4067/ S0718-19572001000100012

Pilleri, G.

1972. Original description of the Gangetic dolphin, Platanista gangetica attributed to William Roxburgh. Bull. Br. Mus. Nat. Hist. (Zool.) 21:345-348.

1978. William Roxburgh (1751-1815), Heinrich Julius Lebeck († 1801) and the discovery of the Ganges dolphin (Platanista gangetica Roxburgh, 1801). Invest. Cetacea 9:11-21.

1979. Pehr Osbeck (1723-1805) and the discovery of the Chinese white dolphin (Sousa chinensis Osbeck, 1765). Invest. Cetacea 10:333-334.

Pilleri, G., and M. Gihr.

1972a. Contribution to the knowledge of the cetaceans of Pakistan with particular reference to the genera Neomeris, Sousa, Delphinus and Tursiops and description of a new Chinese porpoise (Neomeris asiaorientalis). Invest. Cetacea 4:107-162.

1972b. A rare species of dolphin Delphinus tropicalis Van Bree, 1971 (= dussumieri Blanford, 1891) from the coast of Pakistan. Mammalia 36:406-413. https://doi. org/10.1515/mamm.1972.36.3.406
1975. On the taxonomy and ecology of the finless black porpoise, Neophocaena (Cetacea, Delphinidae). Mammalia 39:657-674. https://doi.org/10.1515/ mamm.1975.39.4.657

1976. Osteological differences in the cervical vertebrae of Platanista indi and gangetica. Invest. Cetacea 7:105-108. 1977. Neotype for Platanista indi Blyth, 1859. Invest. Cetacea 8:77-81.

Pilleri, G., and L. Arvy.

1981. The precursors in cetology from Guillaume Rondelet to John Anderson. Invest. Cetacea 12:11-18.

Poole, A. J., and V. S. Schantz.

1942. Catalog of the type specimens of mammals in the United States National Museum, including the biological surveys collection. Bull. U.S. Natl. Mus. 178:703.

Porter, L. J.

1998. The taxonomy, ecology and conservation of Sousa chinensis (Osbeck, 1765) (Cetacea: Delphinidae) in Hong Kong waters. Ph.D. diss., 202 p. Univ. Hong Kong, Hong Kong, China.

2002. A redescription of Sousa chinensis (Osbeck, 1765) (Mammalia, Delphinidae) and designation of a neotype. Bull. Nat. Hist. Mus. Lond. (Zool.) 68:27-37.

Pucheran, M.

1856. Notices mammalogiques. Cétacés. Rev. Mag. Zool. 8:145-149, 315-321, 362-369, 449-460, 545-552.

Quoy, J. R. C., and J. P. Gaimard.

1824. Des cétacés. In Voyage autour du monde, exécuté sur les corvettes du S. M. l'Uranie et la Physicienne pendant les années 1817, 1818, 1819 et 1820, par M. Louis de Freycinet, Zoologie, p. 76-89. Pillet Aîné, Paris.

1830. Zoologie. In Voyage de decouvertes l'Astrolabe exécuté par ordre du Roi, pendant les années 18261827-1828-1829, sous le Commandement de M. J. Dumont d'Urville, vol. 1, 268 p. J. Tatsu, Paris.

Rafinesque Schmaltz, C. S.

1810. Caratteri di Alcuni Nuovi Generi e Nuove Specie di Animali e Piante della Sicilia: con varie osservazioni sopra i medesimi, 105 p. Per de Stampe di Sanfilippo, Palermo, Italy.

1814. Précis des découvertes et travaux somiologiques de m.r C. S. Rafinesque-Schmaltz entre 1800 et 1814 ou choix raisonné de ses principales découvertes en zoologie et en botanique, pour servir d'introduction à ses ouvrages futurs, 55 p. Royale Typographie Militaire, Palermo, Italy.

Rapp, W.

1837. Die Cetaceen Zoologisch-Anatomisch Dargestellt, 182 p. Stuttgart und Tübingen, Stuttgart, Germany.

Rasch, $\mathrm{H}$.

1843. Beskrivelse over en I Christianiafjorden fanget nye delphinart. Nyt Mag. Nat. 4:97-125. [Although usually cited as published in 1845 (which is the date imprinted on the journal), the actual publication date is 1843.]

Rayner, G. W.

1939. Globicephala leucosagmaphora, a new species of the genus Globicephala. Ann. Mag. Nat. Hist. 4:543-544. https://doi.org/10.1080/00222933908527019

Reeves, R. R., and S. Tracey.

1980. Monodon monoceros. Mammal. Species 127:1-7. https://doi.org/10.2307/3503952 
Reichenbach, H. G. L.

1846. Die cetaceen oder walthiere. Abt. 1 Saugethiere. In Die Vollstandigste Naturgesichte des In- und Auslandes. Expedition der Vollstandigsten Naturgesichte (H. G. L. Reichenbach, ed.), vol. 1, p. 53-132. Expedition der Vollfandigten Naturgeichichte, Dresden und Leipzig.

Reinhardt, J.

1862. Om en for den Danske Fauna ny Delphinart (Pseudorca crassidens Owen). Oversigt over det Kongelige Danske Videnskabernes Selskabs Forhandlinger 1862: 103-152.

1866. Pseudorca crassidens, a cetacean hitherto unknown in the Danish fauna. In Recent memoirs on the Cetacea (W. H. Flower, ed.), p. 189-218. R. Hardwicke, London.

Rice, D. W.

1977. A list of the marine mammals of the world, 3rd ed. NOAA Tech. Rep. NMFS SSRF-711, 15 p.

1984. Delphinus truncatus Montagu, 1821 (Mammalia, Cetacea): proposed conservation by suppression of Delphinus nesarnack Lacépède, 1804. Z.N.(S.)2082. Bull. Zool. Nomencl. 41:274-275.

1998. Marine mammals of the world: systematics and distribution. Spec. Publ. 4, 231 p. Soc. Mar. Mammal, Lawrence, $\mathrm{KS}$.

Rice, D. W., and V. B. Scheffer.

1968. A list of marine mammals of the world. U.S. Fish Wildl. Serv., Special Scientific Report - Fisheries 579, 16 p.

Risso, A.

1826. Histoire naturelle des principales productions de l'Europe méridionale et particulièrement de celles des environs de Nice et des Alpes Maritimes, vol. 3, 480 p. F.G. Levrault, Paris.

Robineau, D.

1989. Les types de cétacés actuels du Muséum National d'Histoire Naturelle. I. Balaenidae, Balaenopteridae, Kogiidae, Ziphiidae, Iniidae, Pontoporiidae. Bull. Mus. Natl. Hist. Nat., 4A 11:271-289.

1990. Les types de cétacés actuels du Muséum National d'Histoire Naturelle. II. Delphinidae, Phocoenidae. Bull. Mus. Natl. Hist. Nat., 4A 12:197-238.

2005. Cétacés de France. Collection faune de France 89, 646 p. Fed. Fr. Soc. Sci. Nat., Paris.

Romero, A., A. I. Agudo, and S. J. Blondell de Agudo.

1997. The scientific discovery of the Amazon river dolphin Inia geoffrensis. Mar. Mamm. Sci. 13:419-426. https:// doi.org/10.1111/j.1748-7692.1997.tb00649.x

Rondelet, G.

1554. Libri de piscibus marinis, in quibus veræ piscium effigies expressae sunt. Quæ in tota piscium historia continentur, indicat elenchus pagina nona et decima, 583 p. Matthiam Bonhomme, Lugduni.

Ross, M. J.

1982. Ross in the Antarctic: the voyage of James Clark Ross in Her Majesty's ships Erebus \& Terror, 18391843, 276 p. Caedmon of Whitby, Yorkshire, England.

Roxburgh, W.

1801. An account of a new species of Delphinus, an inhabitant of the Ganges. Asiatic Researches. Trans. Asiatick Soc. 7:170-174.
Rüppell, E.

1842. Beschreibung mehrere neuer sauethiere, in de zoologischen Sammlung der Senckenbergischen anutforshenden Gesellschaft befindlich. Museum Senckenbergianim: Abhandlungen aus dem Gebiete der beschreibenden Naturgeschichte 3:129-144.

Scammon, C. M.

1869. On the cetaceans of the western coast of North America. Edited by Edward D. Cope. Proc. Acad. Nat. Sci. Phila. 21:13-63.

1874. The marine mammals of the north-western coast of North America together with an account of the American whale-fishery, 319 p. John H. Carmany and Co., San Francisco, CA.

Scheffer, V. B., and D. W. Rice.

1963. A list of the marine mammals of the world. USFWS SSR-F 431, 12 p.

Schlegel, H.

1841a. Abhandlungen aus dem gebiete der zoologie und vergleichenden anatomie. Part 2. Weitere beiträge zur naturgeschichte der Cetaceen, 12 p. A. Arnz and Company, Leiden.

1841b. Abhandlungen aus dem gebiete der zoologie und vergleichenden anatomie. Part 1 . Beiträge zur charackteristik der Cetaceen, 44 p. A. Arnz and Company, Leiden.

1844. Les cétacés. In Fauna Japonica, vol. 5, (C. J. Temminck and H. Schlegel, eds.), p. 13-17. Apud Auctorem, Lugduni Batovorum. [Although various dates were imprinted on the title page of this work, and usually 1842 is cited, the actual date of publication for this work was determined to be 1844 .]

1862. Naturrlijke Historie van Nederland. De Dieren van Nederland, 133 p., 20 plates. Haarlem, A. C. Kruseman.

Sclater, W. L.

1891. Catalogue of Mammalia in the Indian Museum, Calcutta. Part 2. Rodentia, Ungulata, Proboscidea, Hyracoidea, Carnivora, Cetacea, Sirenia, Marsupialia, Monotrema, 375 p. Trustees of the Indian Museum, Calcutta, India.

Scoresby, W.

1820. An account of the Arctic regions, with a history and description of the northern whale-fishery, 2 vols. Archiblad Constable and Co., Edinburgh, Scotland.

Shaw, G.

1801. General zoology or systematic natural history, vol. 2, part 2, Mammalia, 560 p. G. Kearley, London.

Sleptsov, M. M.

1955. Novyi vid delfina dal'nevostochnykh morei Lagenorhynchus ognevi sp. nov. [A new species of dolphin from the far eastern seas Lagenorhynchus ognevi species nova]. Tr. Inst. Okeanol. 18:60-68.

Smeenk, C.

2018. A chronological review of the nomenclature of Delphinus rostratus Shaw, 1801 and Delphinus bredanensis (Lesson, 1828). Lutra 61:197-214.

Smeenk, C., M. J. Addink, A. B. van der Berg, C. A. W. Bosman, and G. C. Cadée.

1996. Sightings of Delphinus cf. tropicalis Van Bree, 1971 in the Red Sea. Bonn. Zool. Beitr. 46:389-398.

Smith, A.

1829. Contributions to the natural history of South Africa. Zool. J. 4:433-443. 
1834. An epitome of African zoology; or, a concise description of the objects of the Animal Kingdom inhabiting Africa, its islands and seas. South African Quart. J. 2:16-33, 49-64, 81-97, 113-128, 145-160, 169-192, 209-224, 233-248.

SMM (Society for Marine Mammalogy, Committee on Taxonomy).

2020. List of marine mammal species and subspecies. [Available from https://marinemammalscience.org/species-information/list-marine-mammal-species-subspecies/, accessed 2 November 2020.]

Thomas, O.

1898. The technical names of British mammals. Zoologist 2:97-103.

Tiedemann, D. F.

1808. Zoologie. Zu seinen voreseungren entworfen, 610 p. Landshut, in der Weberschen Buchhandlung.

Tomilin, A. G.

1957. Mammals of the U.S.S.R. and Adjacent Countries. Volume 9: Cetacea. [In Russian] Izd. Akad. Nauk. SSSR, Mosk., 756 p. (Translated by Isr. Program Sci. Transl., Jerusalem, 1967, 717 p.)

Traill, T. S.

1809. Description of a new species of whale, Delphinus melas. In a letter from Thomas Steward Traill, M. D. to Mr. Nicholson. J. Nat. Philos., Chem. Arts 22:81-83.

Trouessart, E. L.

1899. Catalogus mammalium tam viventium quam fossilum, vol. 2, 664 p. R. Friedländer and Sohn, Berolini. [Although the imprint date on the title page is 18981899 , the correct publication date for this volume is 1899.]

True, F. W.

1884. Catalogue of the aquatic mammals exhibited by the United States National Museum. Bull. U.S. Natl. Mus. 27:623-644.

1885. On a new species of porpoise, Phocaena dalli, from Alaska. Proc. U.S. Natl. Mus. 8:95-98.

1889. Contributions to the natural history of the cetaceans. A review of the family Delphinidae. Bull. U.S. Natl. Mus. 36:1-191.

1903. A note on the common bottlenosed porpoise of the North Atlantic, Tursiops truncatus (Montagu). Proc. Acad. Nat. Sci. Phila. 55:313-314.

Tubbs, P. K.

1986. Opinion 1413. Delphinus truncatus Montagu, 1821 (Mammalia, Cetacea): Conserved. Bull. Zool. Nomencl. 43:256-257.

Turvey, S. T., R. L. Pitman, B. L. Taylor, J. Barlow, T. Akamatsu, L. A. Barrett, X. Zhao, R. R. Reeves, B. S. Stewart, $\mathrm{K}$. Wang, et al.

2007. First human-caused extinction of a cetacean species? Biol. Lett. 3:537-540. https://doi.org/10.1098/ rsbl.2007.0292

Vaccaro, O. B., and M. J. Piantanida.

1998. Type specimens of recent mammals housed in national collections of Argentina. Iheringia, Ser. Zool., Porto Alegre 85:67-73.

Van Beneden, E.

1875. Mémoire sur un dauphin nouveau de la Baie de Rio de Janeiro, désigné sous le nom de Sotalia brasiliensis. Mem. Acad. R. Sci., Lett. Beaux-Arts Belg. 41:3-44.
Van Beneden, P. J.

1864. Sur un dauphin nouveau et un ziphiö̈de rare. Mem. Couronnés Autres Mem., Acad. R. Sci. Belles-Lettres Belg. 16:27-45.

1873. Sur deux dessins de cétacés du cap de BonneEspérance. Acad. Sci. Lett. Beaux-Arts Belg. (Ser. 2) $36: 32-40$

1881. Notice sur un nouveau dauphin de la Nouvelle-Zélande. Bull. l'Acad. Roy. Belg. 3:877-887.

1886. Description des ossements fossiles des environs d'Anvers. Part 5: Cétacés. Ann. Mus. R. Hist. Nat. Belg., Paleontol. 13:1-139.

Van Beneden, P. J., and P. Gervais.

1880. Ostéographie des cétacés vivants et fossiles comprenant la description et l'iconongraphie du squelette et du système dentaire de ces animaux ainsi que des documents relatifs à leur histoire naturelle, 634 p., 114 plates. Arteus Bertrand, Paris. [The complete work was published between 1868 and 1880.]

Van Breda, J. G. S.

1829. Aanteekening omtrent eene nieuwe soort van dolfijn. Nieuwe Verh. 2:235-238.

van Bree, P. J. H.

1971a. On Globicephala sieboldii Gray, 1846, and other species of pilot whales (notes on Cetacea, Delphinoidea III). Beaufortia 19:79-87.

1971b. On two skulls of Delphinus dussumieri Blanford, 1891 (notes on Cetacea, Delphinoidea I). Beaufortia 18:169-172.

1971c. Delphinus tropicalis, a new name for Delphinus longirostris G. Cuvier, 1829. Mammalia 35:345-346.

1971d. On the taxonomic status of Delphinus pernettensis de Blainville, 1817 (Notes on Cetacea, Delphinoidea II). Beaufortia 19:21-25.

1973a. On the description and the taxonomic status of Delphinus holboellii Nilsson, 1847 (notes on Cetacea, Delphinoidea VI). Beaufortia 20:129-134.

1973b. Neophocaena phocaenoides asiaorientalis (Pilleri and Gihr, 1973), a synonym of the preoccupied name Delphinus melas Schlegel, 1841 (notes on Cetacea, Delphinoidea 7). Beaufortia 21:17-24.

1974a. On the diagnosis of the South American dolphin Sotalia fluviatilis and its author. Ziet. Saug. 39:57-58.

1974b. Application for the suppression of Delphinus pernettensis de Blainville, 1817 and Delphinus pernettyi Desmarest, 1820, Z.N.(S.) 1974. Bull. Zool. Nomencl. 31:44-48.

1974c. On the taxonomic status of Delphinus pernettenisis de Blainville, 1817 (Notes on Cetacea, Delphinoidea II). Bull. Zool. Nomencl. 31:44-48.

1975. Over de skeletten van twee grieden, Globicephala melaena (Traill, 1809), afkomstig van de massastranding op tholen in 1825. Lutra 17:6-8.

1976. On the correct Latin name of the Indus susu (Cetacea, Platanistoidea). Bull. Zool. Mus. Univ. Amsterdam 5:139-140.

van Bree, P. J. H., and R. Duguy.

1972. Remarques sur quelques delphinides de Museum de la Rochelle et sur la taxomonie du Delphinorhynchus santonicus. Ann. Soc. Sci. Nat. Charente-Marit. 5:171-176. 
van Bree, P. J. H., and D. Robineau.

1973. Notes sur le holotypes de Inia geoffrensis geoffrensis (de Blainville, 1817) et de Inia geoffrensis boliviensis d'Orbigny, 1834 (Cetacea, Platanistidae). Mammalia 37:658-668. https://doi.org/10.1515/mamm.1973. 37.4 .658

van Bree, P. J. H., and W. F. Perrin.

1977. On the diagnosis of the spinner dolphin, Stenella longirostris (Gray, 1828) and its holotype. Zool. Meded. 52:255-259.

van Bree, P. J. H., and M. D. Gallagher.

1978. On the taxonomic status of Delphinus tropicalis van Bree, 1971. (Notes on Cetacea, Delphinoidea IX). Beaufortia 28:1-8.

Van Waerebeek, K., P. J. H. van Bree, and P. B. Best.

1995. On the identity of Prodelphinus petersii Lütken, 1889 and records of dusky dolphin Lagenorhynchus obscurus (Gray, 1828) from the southern Indian and Atlantic oceans. S. Afr. J. Mar. Sci. 16:25-35. https://doi. org/10.2989/025776195784156584

Varela, E. A., G. A. Daneri, M. N. P. Viola, M. F. Negri, C. C.

Di Martino, A. Harrington, R. A. Montiel, M. M. Zambrana,

R. L. Bustos, and O. B. Vaccaro.

2010. Revisión y actualización de la colección de mamíferos marinos del Museo Argentino de Ciencias Naturales "Bernardino Rivadavia” (Buenos Aires, Argentina). Mastozool. Neotrop. 17:213-218.

Viaud-Martínez, K. A., M. M. Vergara, P. E. Gol'din, V. Ridoux, A. A. Öztürk, B. Öztürk, P. E. Rosel, A. Frantzis, A. Komnenou, and A. J. Bohanak.

2007. Morphological and genetic differentiation of the Black Sea harbour porpoise Phocoena phocoena. Mar. Ecol. Prog. Ser. 338:281-294. https://doi.org/10.3354/ meps338281

Vollmer, N. L., E. Ashe, R. L. Brownell Jr., F. Cipriano, J. G.

Mead, R. R. Reeves, M. S. Soldevilla, and R. Williams.

2019. Taxonomic revision of the dolphin genus Lagenorhynchus. Mar. Mamm. Sci. 35:957-1057. https://doi. org/10.1111/mms.12573

von Spix, J. B., and C. F. P. von Martius.

1831. Reise in Brasilien auf Befehl Sr. Majestät Maximilian Joseph I. Königs von Baiern, in den Jahren 1817 bis 1820 gemacht und beschrieben, vol. 3, p. 888-1388. Fleischer, München, Germany.

Wagler, J.

1830. Natürliches system der amphibien, mit vorangehender classification der säugthiere und vögel ein beitrag zur vergleichenden zoologie, 3654 p. J. G. Cotta'schen Buchhandlung, München, Stuttgart und Tubingen.

Wagner, J. A.

1847. Die Säugethiere in Abbildungen nach der Natur, mit Berschreibungen, vol. 7, 427 p. Erlangen, Leipzig, Germany. [While some of the text was available in 1846, the volume that contains both text and plates was apparently published in 1847.$]$

Wang, J. Y.

2018. Bottlenose dolphin, Tursiops aduncus, Indo-Pacific bottlenose dolphin. In Encyclopedia of marine mammals, 3rd ed., (B. Würsig, J. G. M. Thewissen, and K. M. Kovacs, eds.), p. 125-130. Academic Press, London.

Wang, J. Y., A. P. B. Costa, and T. A. Jefferson.

2021. The correct name of Lahille's bottlenose dolphin, Tursiops truncatus gephyreus Lahille, 1908. Mar. Mamm. Sci. 37(2):696-701. https://doi.org/10.1111/ mms.12751

Wang, P.

1999. Chinese cetaceans, 325 p. Ocean Enterprises, Ltd., Hong Kong, China.

Waterhouse, G. R.

1838a. Family-Delphinidae. In The zoology of the voyage of H.M.S. Beagle under the command of Captain Fitzroy, R.N., during the years 1832 to 1836. Part 2: Mammalia (C. Darwin, ed.), p. 25-26. Smith, Elder \& Co., London. [Although the title page says 1839 , the actual date of publication has been determined to be May 1838.]

1838 b. On a new species of the genus Delphinus. Proc. Zool. Soc. Lond. 1838(part 6):23-24.

West, K. L., J. G. Mead, and W. White.

2011. Steno bredanensis (Cetacea: Delphinidae). Mammal. Spec. 43(886):177-189. https://doi.org/10.1644/886.1

Wickert, J. C., S. M. von Eye, L. R. Oliviera, and I. B. Moreno.

2016. Revalidation of Tursiops gephyreus Lahille, 1908 (Cetartiodactyla: Delphinidae) from the southwestern Atlantic Ocean. J. Mammal. 97:1728-1737. https://doi. org/10.1093/jmammal/gyw139

Wiegmann, A. F. A.

1840, 1844. Die Säugethiere in Abbildungen nach der Natur, mit Berschreibungen (Plates 281-385), 105 plates. Erlangen, Leipzig, Germany. [This publication has two correct publication dates, 1840 and 1844. See Appendix F for details.]

Wiig, Ø., and L. Bachmann.

2013. The mammal type specimens at the Natural History Museum, University of Oslo, Norway. Zootaxa 3736:587-597. https://doi.org/10.11646/ zootaxa.3736.5.9

Wilson, E. A.

1907. Mammalia. In National Antarctic expedition 19011904. Natural history. Volume 2: zoology (Vertebrata: Molusca: Crustacea) (F. J. Bell, and L. Fletcher, eds.), p. 1-69. Order of the Trustees of the British Museum, London.

Woodman, N., J. G. Mead, and M. R. McGowen.

2020. "Mostri Marini”: Constantine S. Rafinesque's names for three of Antonino Mongitore's Sicilian whales. Arch. Nat. Hist. 47:344-355.

Zhou, X., X. Guang, D. Sun, S. Xu, M. Li, I. Seim, W. Jie, L. Yang, Q. Zhu, J. Xu, et al.

2018. Population genomics of finless porpoises reveal an incipient cetacean species adapted to freshwater. Nat. Commun. 9:1276. https://doi.org/10.1038/ s41467-018-03722-x 


\section{Appendix A: A note on interpreting the early taxonomic literature}

Many biologists become confused when examining details in the early taxonomic literature, especially those from the eighteenth and nineteenth centuries. In taxonomic studies, the older books, monographs, and papers are extremely important because they contain many of the original descriptions of nominal species (both valid and invalid). This appendix provides guidance for interpreting this older literature.

\section{Publication dates}

Date of publication is exceedingly important in taxonomic literature, as this determines priority and precedence of names. Determining this can be very challenging in the older literature. One must be careful accepting the year of publication on the title page of a book or journal as accurate, because the true date of publication may be different from this. Thus it is important to do some "detective work" and try to find actual publication dates. Fortunately, others may have already determined the true publication dates for important works on cetacean taxonomic history (e.g., Gray and Saunders, 1875; Sherborn, 1891, 1897; Sherborn and Woodward, 1893, 1901a,b,c; Poche, 1911; Smith, 1993; Cretella, 2010; Kinze, 2011; Evenhuis, 2015). In particular, the series of papers by Sherborn provide publication dates for quite a number of the most important taxonomic references of the nineteenth century. These should be consulted, where relevant.

However, it is important also to verify and confirm the true date of publication, as some of the above references contain errors. For instance, J. E. Gray's classic "On the cetaceous animals," which has always been believed to have been published in 1846, was claimed by Evenhuis (2015) to have been published in 1844 . However, this is clearly not the case, as a detailed examination of Gray's monograph shows that it contains no less than 14 references to other published references and even specific events (such as whale strandings) that occurred in 1845 or 1846 (these occur on Gray's pages $15,26,27,28,31,35,46,47,49,51$, and 52). Therefore, the actual publication date cannot be 1844 and is confirmed to be 1846 .

\section{Authorship}

Similar to date of publication, authorship can sometimes be difficult to ascertain. In older publications it was common to include passages written by a different author than the one listed on the title page. This fact needs to be considered carefully, and every attempt should be made to determine the true authorship of type descriptions (which may have to be cited as something like "Owen in Gray, 1866" for the case in which Richard Owen penned the relevant description of Orcaella brevirostris in John E. Gray's 1866 catalog.

In other cases, credit for the naming of a species may be explicitly given to a different person than the one who actually authored the relevant account, and this should be considered as well (Article 50.1.1 of the Code - ICZN, 1999). An example of this is the case of Delphinus geoffrensis, in which Desmarest explicitly credited authorship to Blainville, in Desmarest (1817).

\section{Anatomical descriptions}

Anatomical descriptions in the early literature can be quite difficult to decipher. Besides the use of old fonts and challenges associated with inaccurate translations, many older references use terms that are now outdated and which may be quite unfamiliar to the modern biologist. For instance, in the literature of the 1800 s, the blowholes of a cetacean may be referred to as "spiracles" or even called "blowers."

\section{Measurements}

Measurements provided in older literature should also be subject to scrutiny, as units of measurement in the past were not always as well standardized as they are today, and in any event could vary from country to country. For instance, the English foot of 12 inches $(30.48 \mathrm{~cm})$ was slightly different in Scandinavian countries. As an illustration of this, Flower (1866) provided a table in his Preface which gave the Danish (1.0298) and Swedish (0.9742) equivalents of the English foot (1.0). This is just one example of where a foot is not always a foot (12 inches).

\section{Illustrations}

While some early illustrations did an admirably accurate job of reflecting the recognizable features of the species we recognize today (see Figs. A1, A2 lower three, A3), others are simply not identifiable to species (Figs. A2 top, A4, and A5 top), or sometimes even to genus or family (Fig. A6). Yet others were not very accurate at all, but nevertheless show diagnostic features that allow them to be identified (Fig. A5 lower three). Thus, while illustrations are often extremely useful in determining the true identification of animals involved in these early type descriptions, some skepticism must be applied to many of the features shown.

Early illustrations of cetaceans often showed the animals with spouts of water jetting from the blowhole(s), or with gills, or fin spines (Fig. A7), all of which are not accurate, and which originated from a 
time when it was not widely recognized that cetaceans are mammals, not fish. These elements in an illustration indicate that such renderings were often made from memory or from crude descriptions after the specimen was examined, and may be more reflective of the artist's image of what the animal was, rather than a true sketch of what was really there. They also remind us that other elements of these old illustrations must often be taken with a large "grain of salt."

\section{Literature cited}

Cretella, M.

2010. The complete collation and dating of the section $\mathrm{Zo}_{\mathrm{o}}$ ologie of the Coquille voyage. Boll. Malacol. 46:83-103.

Cuvier, G.

1812. Rapport fait à la classe des sciences mathématiques et physiques, sur divers cétacés pris sur les côtes de France, principalement sur ceux qui sont échoués près de paimpol, le 7 Janvier 1812. Ann. Mus. Hist. Nat. 19:1-16.

Desmarest, A. G.

1817. Dauphin. In Nouveau dictionnaire d'histoire naturelle, appliquée aux arts, à l'agriculture, à l'économie rurale et domestique, à la médicine, etc. par une société de naturalistes et d'agriculteurs, nouvelle édition, vol. 9, p. 146-180. Deterville, Paris.

Evenhuis, N. L.

2015. Publication and dating of the "Zoology of the Voyage of the H.M.S. Erebus and Terror." Sherbornia 2:9-20.

Flower, W. H. (ed.).

1866. Recent memoirs on the Cetacea by Professors Eschricht, Reinhardt and Lilljeborg, 312 p., 6 plates. R. Hardwicke, London.

Freminville, $\mathrm{M}$.

1812. Notice sur espèce de dauphin observée dans la mer glaciale. Nouv. Bull. Sci., Soc. Philom., Paris 3(56):71.

Gervais, P.

1853. Remarques sur les mammifères marins qui frequentent les côtes de la France et plus particulièrement sur une nouvelle espèce de dauphins propre à la Méditerranée. Bull. Soc. Cent. Agric. Dép. l'Hérault, Montpelier 40:140-156.

Gray, J. E.

1846. On the cetaceous animals. In The zoology of the voyage of H.M.S. Erebus and Terror, under the command of Captain Sir James Clark Ross, R.N., FR.S., during the years 1839 to 1843 . Volume 1: Mammalia, birds (J. Richardson and J. E. Gray, eds.), p. 13-53. E. W. Janson, London.

1866. Catalogue of seals and whales in the British Museum, 2nd ed., 402 p. Order of the Trustees, London.

Gray, J. E., and J. Saunders.

1875. List of the books, memoirs, and miscellaneous papers by Dr. John Edward Gray, F.R.S., 58 p. Printed for private distribution, London. [Although the imprint date on the title page is 1872 , Saunders later corrected the publication date to be 1875 .]

ICZN (International Commission on Zoological Nomenclature). 1999. The international code of zoological nomenclature, 4th ed., 306 p. International Trust for Zoological Nomenclature, London.
Jacquinot, H., and J. Pucheran.

1853. Mammifères et oiseaux. In Voyage au pole sud et dans l'Océanie sur les corvettes L'Astrolabe et la Zélée, Zoologie, vol. 3, part 1 (J. Hombron and H. Jacquinot, eds.), p. 7-166. Gide et J. Baudry, Paris.

Kinze, C. C.

2011. Daniel Frederik Eschricht (1798-1863), his investigations on cetaceans and the nordic whales in particular. Hist.-meereskund. Jahrb. (Hist. Oceanogr. Yearb.) 17:65-96.

Poche, F.

1911. Über den Inhalt und die Erscheinungszeiten der einzelnen Teile, Hefte etc. und die verscheidenen Ausgaben des Schreber'schen Säugetierwerkes (1775-1855). Arch. fur Naturgesh. 77(Band 1, Suppl. 4):124-183.

Quoy, J. R. C., and J. P. Gaimard.

1824. Des cétacés. In Voyage autour du monde, exécuté sur les corvettes du S. M. l'Uranie et la Physicienne pendant les années 1817, 1818, 1819 et 1820, par M. Louis de Freycinet, Zoologie, p. 76-89. Pillet Aîné, Paris.

1830. Voyage de decouvertes l'Astrolabe exécuté par Ordre du Roi, pendant les années 1826-1827-1828-1829, sous le Commandement de M. J. Dumont d'Urville. Zoologie, 268 p. J. Tatsu, Paris.

Reichenbach, H. G. L.

1846. Die cetaceen oder walthiere. Abt. 1 Saugethiere. In Die Vollstandigste Naturgesichte des In- und Auslandes. Expedition der Vollstandigsten Naturgesichte (H. G. L. Reichenbach, ed.), vol. 1, p. 53-132. Expedition der Vollfandigten Naturgeichichte, Dresden und Leipzig.

Sherborn, C. D.

1891. On the dates of the parts, plates, and text of Schreber's 'Säugthiere'. Proc. Zool. Soc. Lond. 1891:587-592.

1897. Note on the dates of "The Zoology of the 'Beagle’”. Ann. Mag. Nat. Hist. 20:483. https://doi. org/10.1080/00222939708680665

Sherborn, C. D., and B. B. Woodward.

1893. On the dates of the 'Encyclopédie Méthodique' (Zoology). Proc. Zool. Soc. Lond. 1893:582-584.

1901a. Notes on the dates of publication of the natural history portions of some French voyages.-Part I. 'Amérique méridionale'; 'Indes orientales'; 'Pôle Sud' ('Astrolabe' and 'Zélée'); 'Las Bonite'; 'La Coquille'; and 'L'Uranie et physicienne’. Ann. Mag. Nat. Hist. 7:388-392. https:// doi.org/10.1080/00222930108678490

1901b. Dates of publication of zoological and botanical portions of some French voyages, part 2. Ferret and Galinier's 'Voyage en Abyssinie'; 'Exploration scientificue de l'Algerie'; Castelnau's 'Amerique du Sud'; Dumont d'Urville's 'Voyage de l'Astrolabe'; ... Ann. Mag. Nat. Hist. (Ser. 7) 8(no. 44):161-164.

1901c. Dates of publication of zoological and botanical portions of some French voyages, part 2. Ferret and Galinier's 'Voyage en Abyssinie'; 'Exploration scientificue de l'Algerie'; Castelnau's 'Amerique du Sud'; Dumont d'Urville's 'Voyage de l'Astrolabe'; ... (continued). Ann. Mag. Nat. Hist. 1901:333-336.

Smith, J. C.

1993. Georges Cuvier: an annotated bibliography of his published works, 251 p. Smithsonian Institution Press, Washington, D.C. 


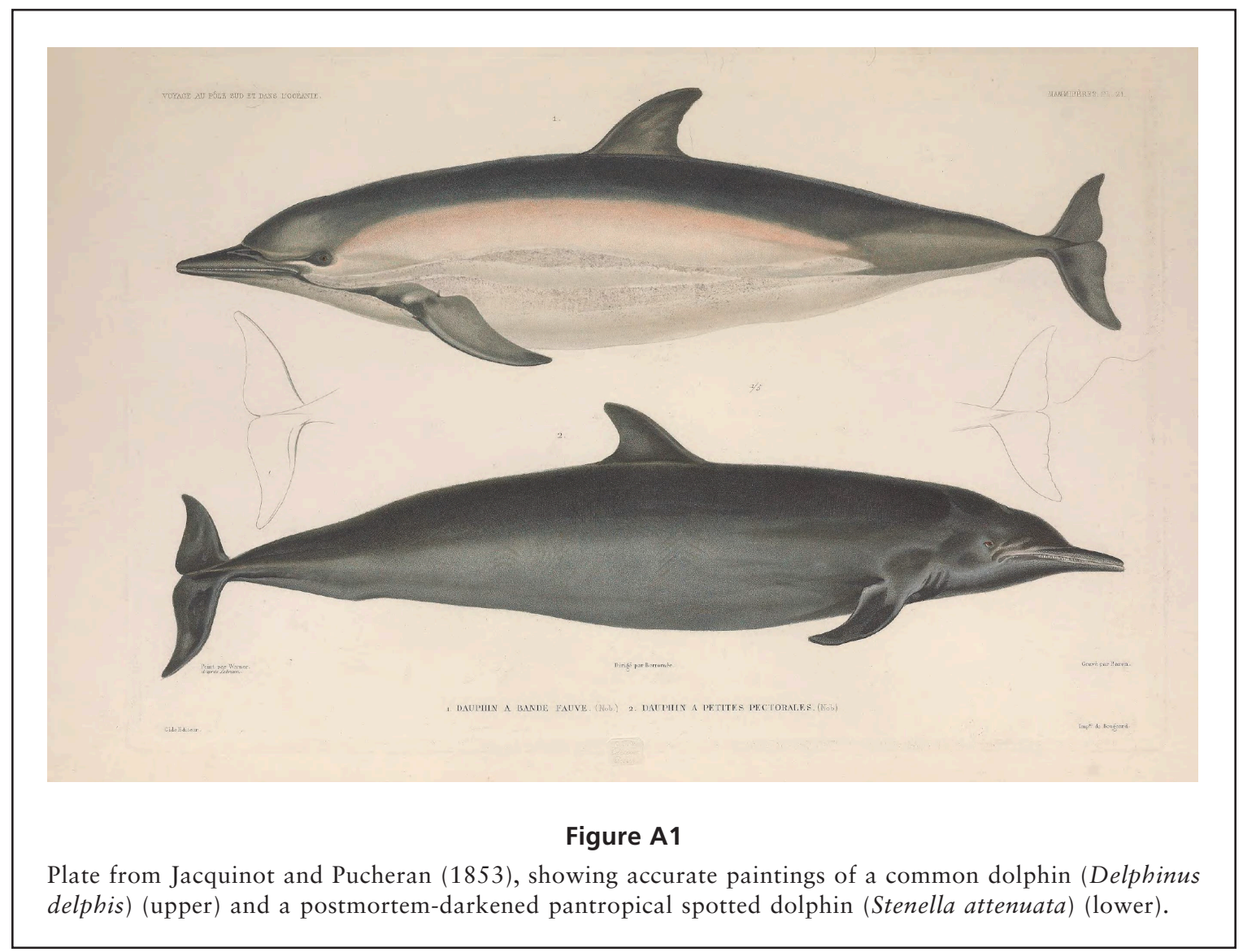




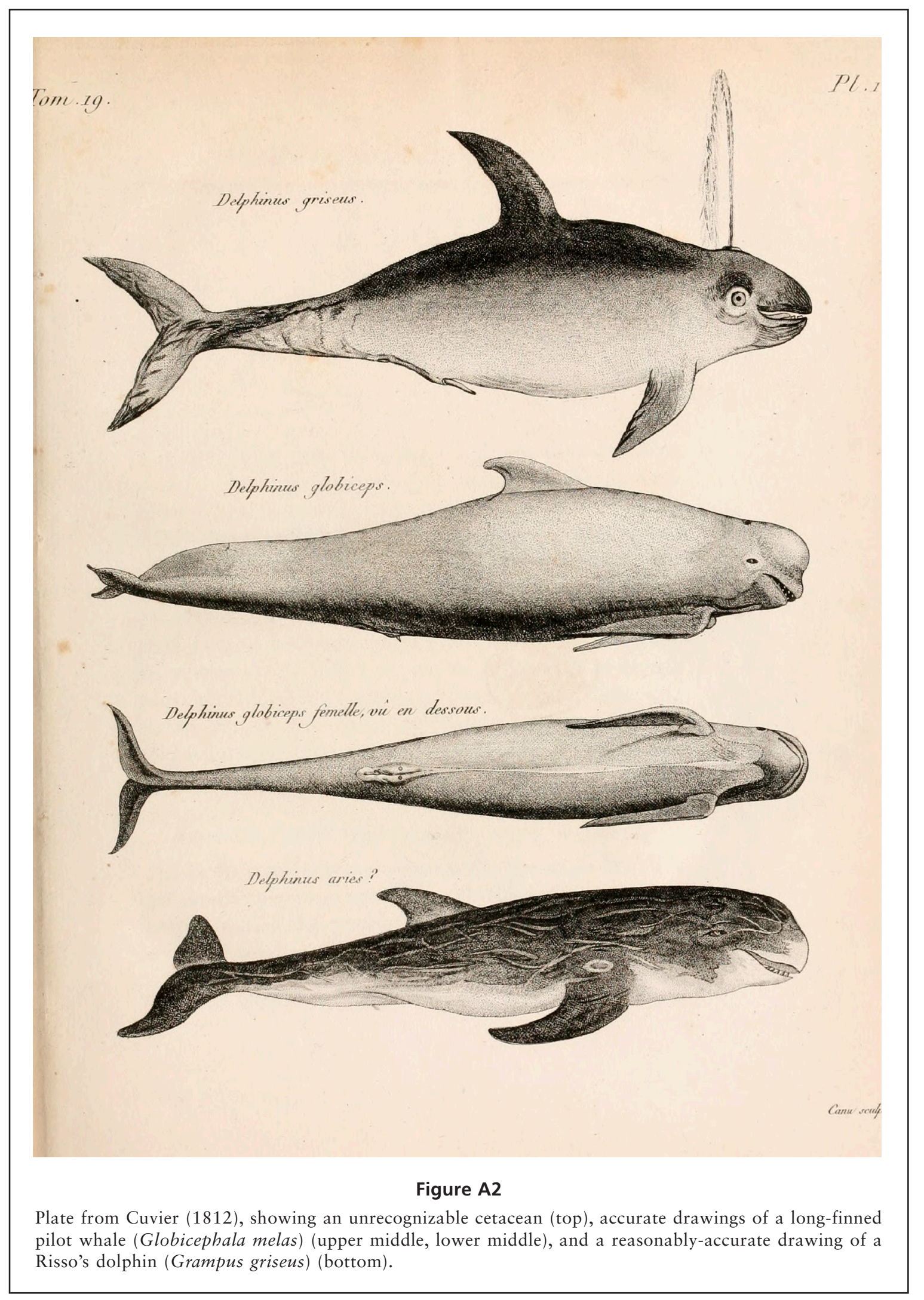




\section{Expedition de F. de Castehau (Américue du Sud).

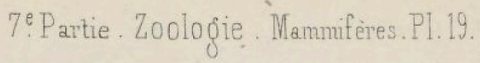
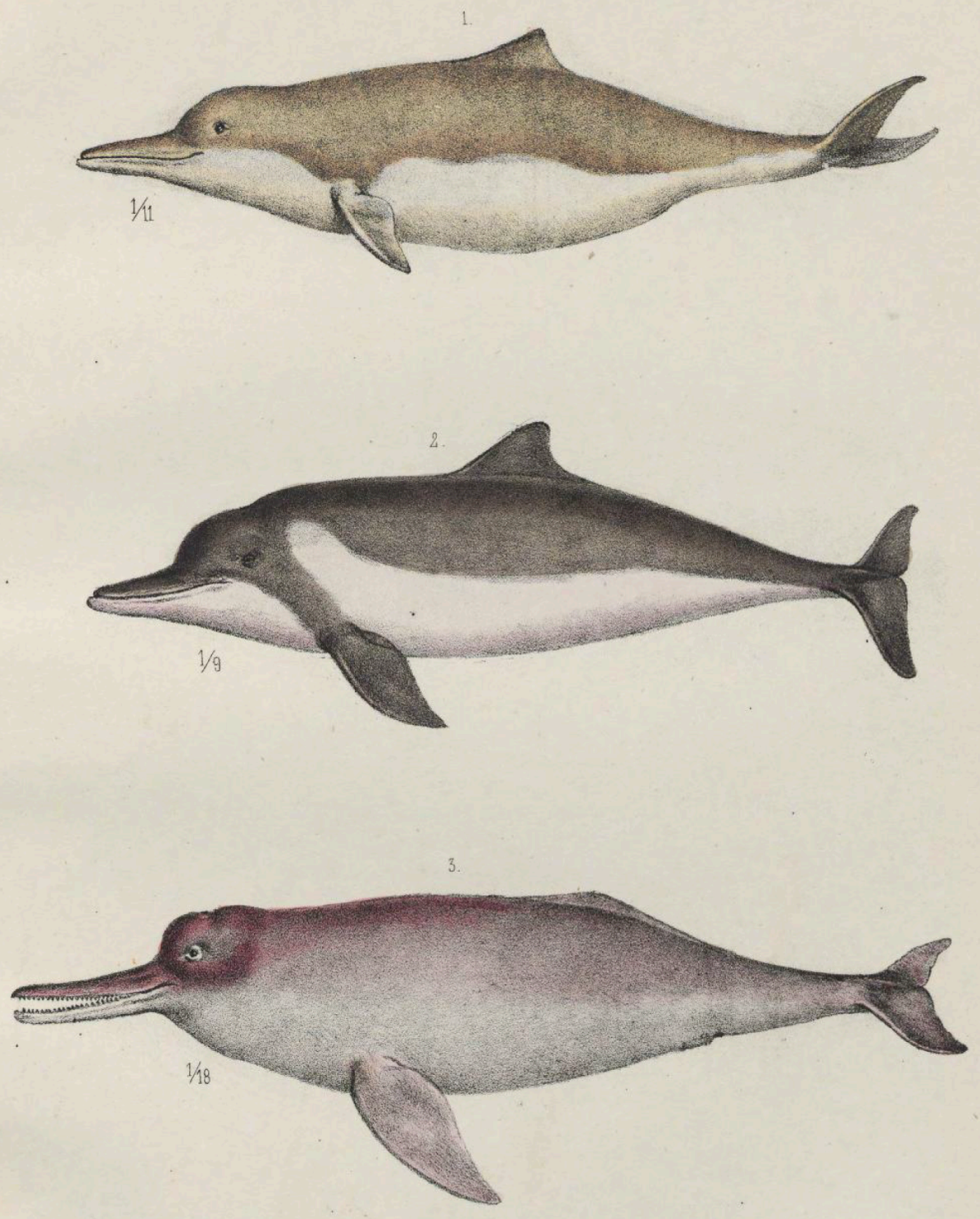

Wemer Lith.

\section{DELPHINUS PALLIDUS. 2. DELPHINUS FLUVIMTIIS.}

3. INIA GEOFFRENSIS.

\section{Figure A3}

Plate from Gervais (1853), showing accurate and recognizable paintings of Sotalia spp. (upper and middle), and an Amazon river dolphin (Inia sp.) (lower). While the proportions are a bit off, these are all easily identifiable to at least genus level. 


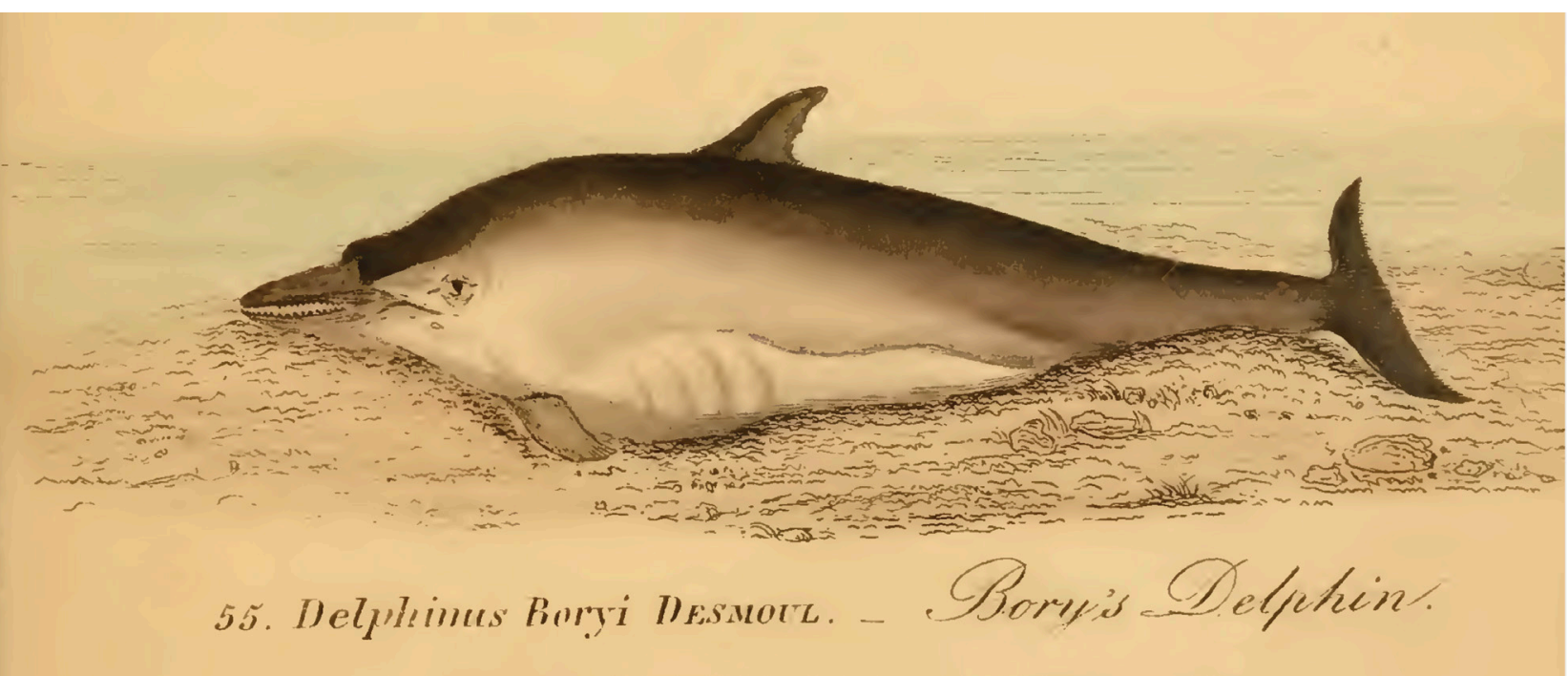

Figure A4

Plate from Reichenbach (1846), showing a dolphin of the subfamily Delphininae, but unrecognizable to species. 


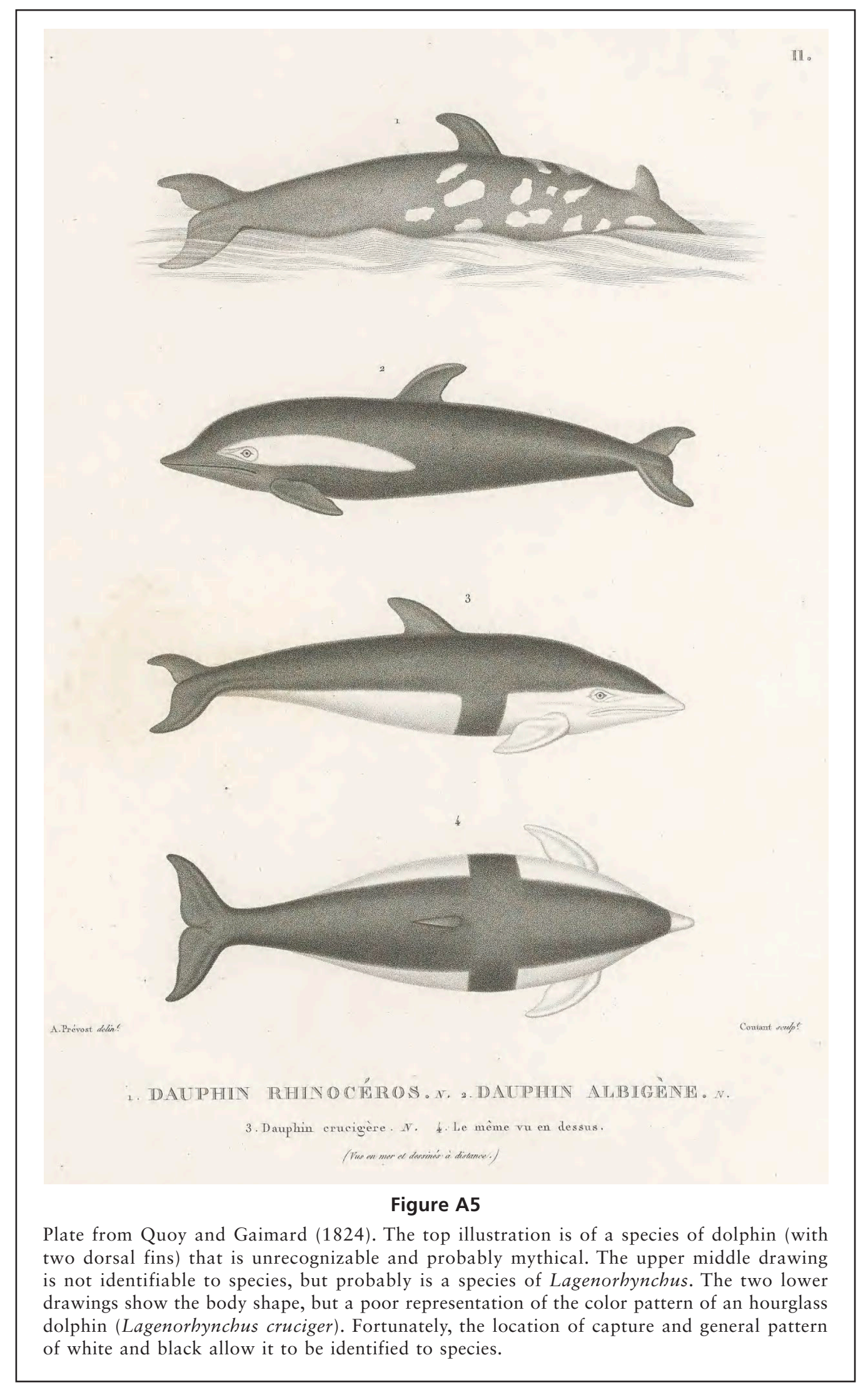




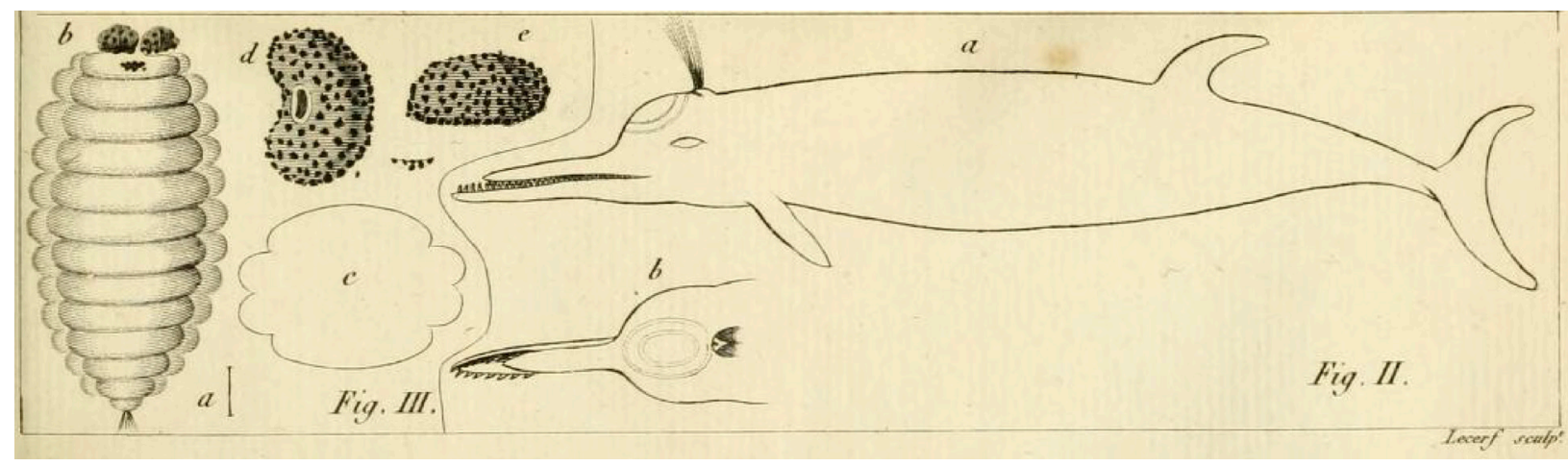

Figure A6

Plate from Freminville (1812), with fig. II showing an unrecognizable cetacean that is supposedly a dolphin, but shows more characteristics of a beaked whale (e.g., long, spindle-shaped body, un-notched flukes, dorsal fin set well back on the body). The presence of many teeth in the jaws, however, does not suggest a beaked whale. 


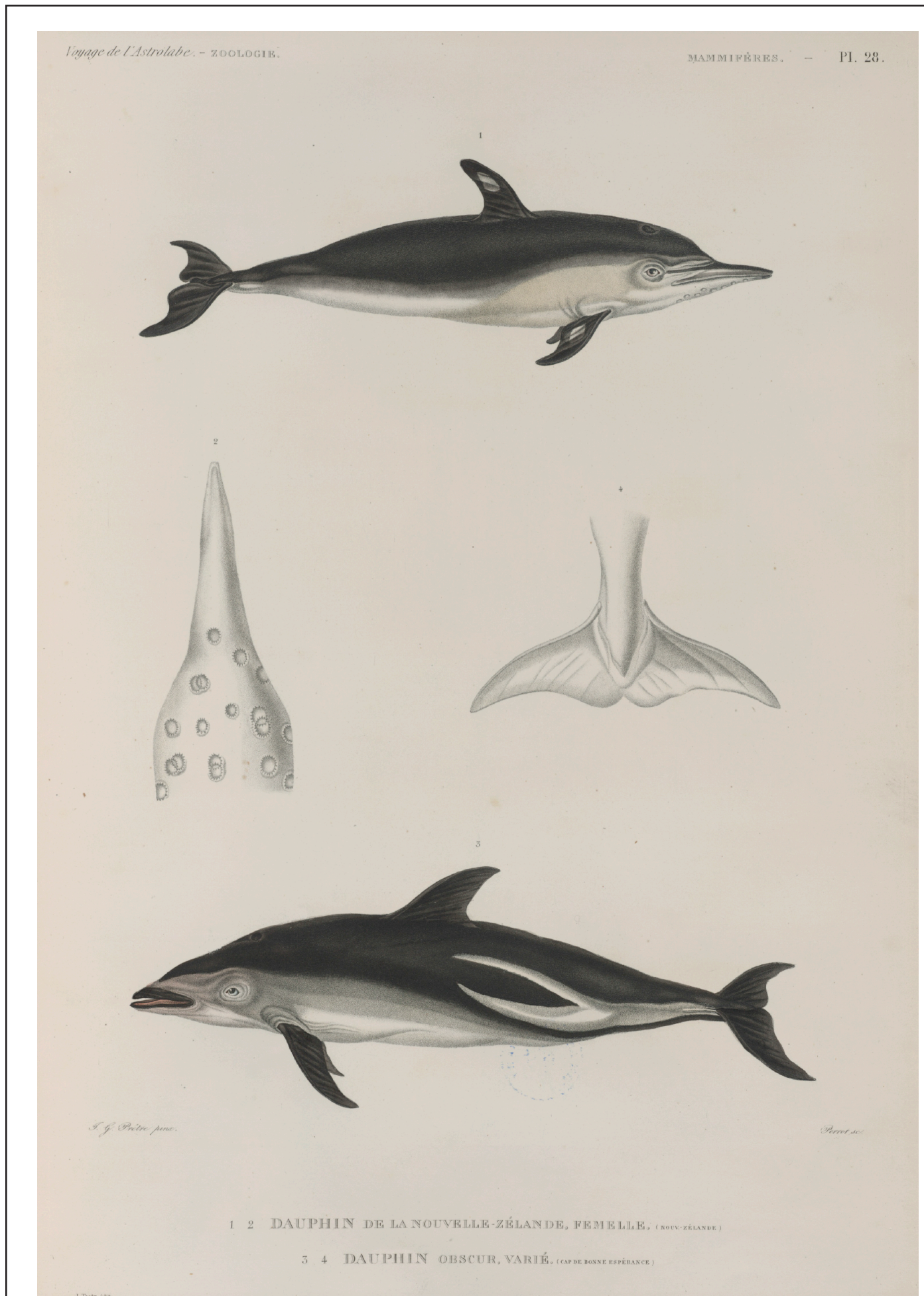

Figure A7

Plate from Quoy and Gaimard (1830), showing dolphins with fin rays. The top painting could be of either the genus Delphinus or Stenella, but other information allowed it to be identified as a common dolphin (Delphinus delphis). The bottom painting, while not very accurate, shows enough diagnostic features to be identifiable as a dusky dolphin (Lagenorhynchus obscurus). 


\section{Appendix B: Short biographies of the major describers of delphinoid cetaceans}

A large proportion of the 350 or so species of dolphins and porpoises have been described by a few biologists. As these men had a great impact on this field, it is instructive to know about their work and their professional (and personal) lives. The short biographies below provide some background on 11 of those that I perceive to be the most important such natural historians.

\section{Edward Drinker Cope (1840-1897)}

One of the premier American zoologists of the nineteenth century, Edward Cope was well known, sometimes revered and other times despised, for his strongly-held intellectual and socio-political views. At the Academy of Natural Sciences in Philadelphia, he studied nearly all aspects of zoology, but was best known for his work on fishes, amphibians, and reptiles, including studies of both extant and fossil species. Despite his almost superhuman publication record (with over 1,400 papers, books, and monographs), he did not publish extensively on living marine mammals (and he apologized for this in one of his late-career papers, blaming "incompetence" at his institution for this shortcoming). Nevertheless, he described more species of dolphins and porpoises (20) than anyone else, other than John Gray. None of his species of delphinoid cetaceans are recognized today as valid.

\section{Jean Léopold Nicolas Frédéric, Baron Cuvier (known as Georges Cuvier) (1769-1832)}

Perhaps one of the two greatest biologists of the nineteenth century (the other being Charles Darwin), French zoologist Georges Cuvier ${ }^{1}$ had extensive influence in several areas of natural history, including through his revolutionary (but ultimately, largely wrong) ideas about the evolution of life and the extinction of species. He published massive numbers of papers and books; his bibliography lists 908 of them. Most importantly, he produced several of the most influential treatises of the day on the animal kingdom, with detailed coverage of both living and extinct species. He is still known today as the founder of comparative anatomy. Although he did not describe a large number of dolphin and porpoise species, a higher proportion of Cuvier's species are considered valid today than those of any other biologist (4 of 11).

\footnotetext{
${ }^{1}$ Georges Cuvier's younger brother, Frederic, also published important works on cetaceans.
}

\section{John Edward Gray (1800-1875)}

British biologist John Gray described more than three times as many dolphins and porpoises $(73$ species in total) than any other person. Gray was associated with the British Museum (Natural History) for his entire career and was Keeper of Zoology from 1840 until his death in 1875 . He published extensively, producing at least 1,164 publications on a wide variety of natural history topics, with marine mammals as a major focus of his later career. Gray was not a theorist, nor a field biologist, and largely stayed at his post in the museum compiling lists and catalogs of specimens that were being collected by British colonial expeditions and voyages. He is remembered as a highly productive, but somewhat sloppy and ornery, naturalist of the Victorian era. See Appendix C for a more detailed and thorough biography of Gray.

\section{Bernard Germain Etienne de Laville-sur-Ilon Lacépède (1756-1826)}

Lacépède was a French zoologist who wrote one of the very first compilations and reviews of the cetaceans covering those species known at the start of the nineteenth century. This book, Histoire Naturelle des Cetacees, was first published in 1804 and was widely cited and reprinted in various forms over the following decades. It provided color illustrations of the known species, and Lacépède added several new species that he described himself. Most of his 13 species are no longer valid, and his species accounts tended to be very flowery and somewhat fanciful; nonetheless his works form an important part of the early taxonomic history of the Cetacea.

\section{Rene Primevere Lesson (1794-1849)}

Rene Lesson was a French naturalist and surgeon of the nineteenth century. His specialties were ornithology and herpetology, but he also published several books and monographs on mammals, including cetaceans. Early in his career, he served as a naturalist on the global voyage of the French vessel, La Coquille (1822-1825), on which he collected many natural history specimens. A fairly large number (15) of small cetaceans were among the species he described (some from the voyage of La Coquille), but the vast majority of them are no longer considered valid species.

\section{Sir Richard Owen (1804-1892)}

Perhaps best known for his work on terrestrial mammals, British biologist Sir Richard Owen was a super- 
star of nineteenth-century natural history. He had a long career and died at the ripe old age of 89 years. Owen was a proponent of the practice and promise of comparative anatomy, and served at the Royal College of Surgeons and later the British Museum for many years. His biological worldview, based on comparative anatomy, was largely replaced with the advent of evolutionary biology resulting from the publication of Darwin's On the Origin of Species in 1859. Owen famously feuded with several contemporaries over both scientific and administerial approaches and interpretations. He described the false killer whale (Phocaena [now Pseudorca] crassidens), based on a subfossil specimen, and thought the species likely extinct (he was wrong). His greatest contribution to the field was a monograph on small cetaceans of India, which gave us several new species of cetaceans, some of which are still valid (and one of which may soon be resurrected). Overall, he described nine species, with three of them still valid.

\section{Titian Peale (1799-1885)}

American Titian Peale, an artist and naturalist, was the son of the famous museum founder Charles Wilson Peale. Titian Peale's single contribution to the taxonomy of the cetaceans was a monograph on the birds and mammals collected during the U.S. Exploring Expedition (known as the "Ex Ex"), which took place using a fleet of vessels from 1838 to 1842 . Six new species of dolphins and porpoises were described therein, and two are still recognized as valid. Peale's monograph was perceived to contain too many taxonomic errors and was thus withdrawn (making it now very rare in its original form). A decade later it was replaced by a similar volume authored by John Cassin that included changes to many of the scientific names, but much of the text was nearly identical to Peale's. Although not individually credited, the plates illustrating the cetaceans were likely prepared by Peale.

\section{Rodolfo Armando Philippi (1808-1904)}

Rodolfo Philippi was a Chilean paleontologist and zoologist of German descent. He conducted studies of the cetaceans and pinnipeds of South America while at his museum post in Santiago, Chile. Philippi published a number of important papers on South American dolphins and porpoises. He described eleven new species, none of which is considered valid today.

\section{Hermann Schlegel (1804-1884)}

Although mostly known for his work in ornithology and herpetology, Hermann Schlegel also conducted important studies on marine mammals, small cetaceans prominently among them. Much of his career was spent working in Austria and later in the Netherlands. In 1858 he became the curator of the natural history museum in Leiden (Rijksmuseum van Natuurlijke Historie, today known as "Naturalis"). This institute held the third largest collection of marine mammal specimens in Europe at the time, after London and Paris. Schlegel published two important monographs on cetaceans in 1841 , naming six new species (though none of these is considered valid today).

\section{Pierre Joseph Van Beneden (1809-1894)}

The Belgian biologist is best known for his massive classic monograph, co-authored with French zoologist Paul Gervais, which included an extensive and beautifullyillustrated atlas of large plates of the skeletal structures of both living and fossil cetaceans (it was published in parts between 1868 and 1880). That monograph has remained invaluable to any person interested in the detailed structure of cetacean bones and skulls. Van Beneden wrote and published extensively on cetaceans, mostly in French, though most of his work is not well known to scientists today. He described seven species of dolphins and porpoises, but only two of them are still considered valid.

\section{Arend Friedrich August Wiegmann (1802-1841)}

Wiegmann was a German zoologist who mainly studied reptiles and amphibians, but is also well known for founding the journal Archiv für Naturgeschichte. As far as I know, Wiegmann never did any work on marine mammals, but he was nonetheless assigned to complete the cetacean sections of Schreber's Die Sangethiere (after the death of lead author, Schreber). However, Wiegmann was unable to complete the task, as he also died at an early age (38 years). Before he died, though, he commissioned several plates introducing new species names. Under the rules of the ICZN, these names established before 1931 with an "indication" (the illustrations in the plates) are available. Nine dolphin and porpoise names are therefore credited to him, though none of these is still considered valid. See Appendix F for more details on the authorship and dating of relevant marine mammal sections of Schreber's Die Sangethiere. 


\section{Appendix C: John Edward Gray (1800-1875): his contributions to marine mammal biology}

\section{Introduction}

No one has described more nominal species of delphinoid cetaceans than John Edward Gray (Fig. C1). Gray spent his entire career at the British Museum (Natural History). He was Assistant in the Department from 1824 to 1840 , and then Keeper of Zoology from 1840 until his death in 1875 , a period in which British exploring expeditions were bringing back zoological specimens at a pace that had never been seen before (Gunther, 1975). He is, without a doubt, one of the most important scientists in the early history of marine mammal research. Early in his career, Gray stated that one of his main aims at the British Museum was to amass the largest and best collection of zoological specimens in the world. In this, he was undoubtedly successful, because during his tenure the British Museum grew from a poorly organized and undocumented small collection to the largest set of zoological material in the world. This accomplishment was due to Gray's efficiency, ambition, and boundless energy (Gunther, 1975). He is credited by many for a ceaseless push to advance the natural history department of the museum, while battling the museum trustees, who were more interested in developing other areas at the time. Gray was not a field biologist and did not have a graduate degree, but having grown up in a family with many naturalists, was an expert on multiple taxa.

\section{Importance of Gray's work on marine mammals}

Gray published extensively throughout his career. The published list of his books, memoirs, and papers lists 1,162 references, and I know of two additional ones that seem to have been inadvertently left off the list, making the total 1,164 (Gray and Saunders, 1875).

His most important contributions are the monograph "On the cetaceous animals," contained in the zoology section of Ross' voyage of the H.M.S. Erebus and Terror (Gray, 1846) ${ }^{1}$, and five catalogs that documented and described the marine mammal specimens in the British Museum (Gray, 1850, 1866, 1868, 1871, 1874). These publications provided type descriptions of a large proportion of the nominal species of marine mammals, and some are still recognized as valid species. He also authored many of the genera of marine mammals.

\footnotetext{
${ }^{1}$ It is noteworthy, considering the number of new species described therein, that Gray's "On the cetaceous animals" (1846), though published in the official results of the 1838-1843 voyage of the H.M.S. Erebus and Terror (known as the Ross Antarctic Expedition), contains virtually no information about specimens collected during that voyage. In fact, it is possible that none of the new cetacean species described in that paper were actually collected during the voyage.
}

As a colleague, Gray could, at times, be very kind and supportive, but at other times, was a brash, arrogant antagonist, often willing to indulge his desire to say whatever popped into his head, no matter how degrading. Sir Joseph Hooker, the naturalist on the voyage of the H.M.S. Erebus and Terror, who was well acquainted with Gray, captured it well when he said (Huxley, 1918, p. 73): "Dr. Gray had a loosetongued habit, if anyone came under his criticism, of heaping reckless abuse upon him, quite out of proportion and often self-contradictory... Dr. Gray is not really malignant... he has all the attributes of malignancy, except malignance - there then!”

\section{Over-splitting, errors, and other problems}

Gray was prolific, and he made many contributions to marine mammal biology. But, he had a mixed reputation among his contemporaries, as well as among later workers, because: 1 ) His contributions were mainly descriptive, and he contributed little to hypotheses or general concepts of marine mammal biology, and 2) Gray was primarily concerned with quickly documenting and revealing to a larger audience the massive collections that were being acquired by the British Museum. Many believe that he was concerned more with quantity of publications than with quality. His papers and catalogs show evidence of this, containing a surprising number of errors, contradictions, and other blunders.

Although there is little doubt that his colleagues were well aware of these deficiencies, it was not until eight years after Gray's death (in 1875) that an honest criticism of his work with marine mammals was published. This came from his colleague, William Henry Flower, who had taken over curatorship of marine mammal specimens at the British Museum, and found them in a state of "chaos" (Flower, 1884, p. 467): “[Gray's] tendency to multiply divisions and impose names almost at random, his want of accuracy in description, and his defective anatomical knowledge, are exhibited in his writings on this group in their fullest development. Individual peculiarities, or such as are the effects of immaturity ... or of accidental mutilation ... or of mistaken impressions gathered from imperfect photographic representations ... are made the foundations of generic distinctions, which are maintained in successive catalogues and lists, notwithstanding the exposure of the errors upon which they were based. Specimens between which no one else finds any specific distinction are placed in different genera... Even the same individual specimen occurs twice over in the same list in different genera...". 
It seems likely that American zoologist Frederick W. True (1889) had Gray in mind when he vented his frustration about the state of dolphin taxonomy. True clearly recognized that some variation associated with each character will be natural in any population, and that these do not necessarily indicate separate species. Gray, on the other hand, was well known for describing new species based on a single specimen, sometimes quite incomplete or damaged. He seemed to have had little appreciation for the concepts of sexual, developmental, or individual variation in characters, much less of intraspecific geographic variation (which we now recognize as the raw material of evolution). The latter may be partly accounted for by his devout religious faith and strong conviction, maintained until his death, that species did not evolve. He rejected and argued against Darwin's theory of evolution by natural selection (Darwin, 1859).

\section{Conclusion}

Gray's work on cetaceans gets mixed reviews overall, but the assessment of Gunther (1975) that "his descriptions of cetaceans, derived from single specimens that had not turned up for over a hundred years, have proved correct" is not accurate (see above). In fact, most of Gray's described cetacean species are no longer recognized as valid. Today, it can be extremely frustrating to go through all of the nominal species that he introduced with minimal description, and based on only one or a few specimens. It has made determining proper nomenclature for many cetaceans a thorny mess. Nonetheless, we owe the type descriptions of many species of cetaceans to his efforts, and his work remains a crucial part of the early history of marine mammal taxonomy.

\section{Literature cited}

Darwin, C.

1859. On the origin of species by means of natural selection, or the preservation of favoured races in the struggle for life, 513 p. J. Murray, London.

Flower, W. H.

1884. On the characters and divisions of the family Delphinidae. Proc. Zool. Soc. Lond. 1883:466-513. [Although the date imprinted on the header of the paper is $20 \mathrm{No}-$ vember 1883, a handwritten note by the author (Flower) on a reprint sent to Agassiz indicates that it was actually published on 1 April 1884.]

Gray, J. E.

1846. On the cetaceous animals. In The zoology of the voyage of H.M.S. Erebus and Terror, under the command of Captain Sir James Clark Ross, R.N., FR.S., during the years 1839 to 1843 . Volume 1: Mammalia, birds (J. Richardson and J. E. Gray, eds.), p. 13-53. E. W. Janson, London.

1850. Catalogue of the specimens of Mammalia in the collection of the British Museum. Part 1, Cetacea, 153 p., part 2, seals, 48 p. Order of the Trustees, London.

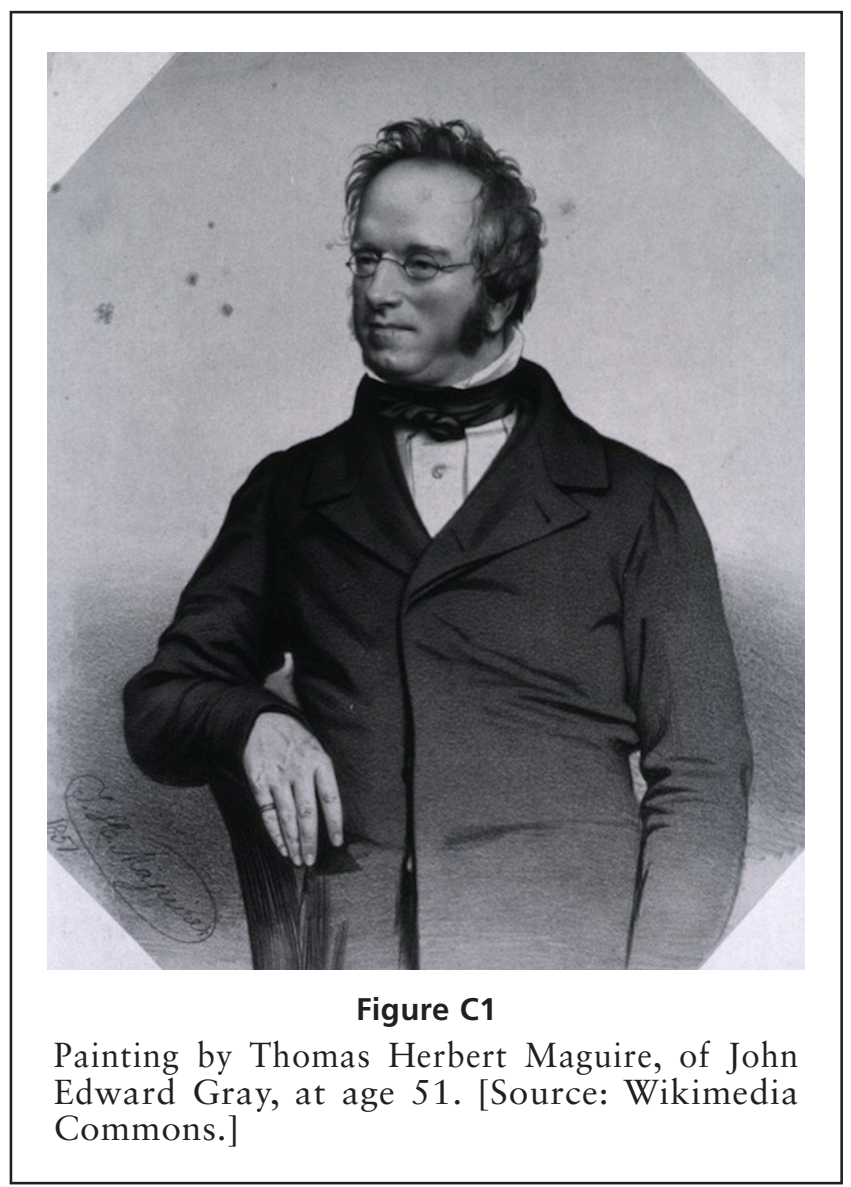

1866. Catalogue of seals and whales in the British Museum, 2nd ed., 402 p. Order of the Trustees, London.

1868. Synopsis of the species of whales and dolphins in the collection of the British Museum, 10 p., 37 plates. Bernard Quartitch, London.

1871. Supplement to the catalogue of seals and whales in the British Museum, 103 p. Order of the Trustees, London.

1874. Hand-list of seals, morses, sea-lions, and sea-bears in the British Museum, 43 p., 30 plates. Order of the Trustees, London.

Gray, J. E., and J. Saunders.

1875. List of the books, memoirs, and miscellaneous papers by Dr. John Edward Gray, F.R.S., 58 p. Printed for private distribution, London. [Although the imprint date on the title page is 1872 , Saunders later corrected the publication date to be 1875 .]

Gunther, A. E.

1975. A century of zoology at the British Museum through the lives of two keepers, 1815-1914, 533 p. Dawsons of Pall Mall, London.

Huxley, L.

1918. Life and letters of Sir Joseph Dalton Hooker, O.M., G.C.S.I., based on materials collected and arranged by Lady Hooker, 2 vols. J. Murray, London.

True, F. W.

1889. Contributions to the natural history of the cetaceans. A review of the family Delphinidae. Bull. U.S. Nat. Mus. 36:1-191. 


\section{Appendix D: Museum and collection acronyms}

AM: Australian Museum, Sydney, Australia

AMNH: American Museum of Natural History, New York City, USA

ANSP: Academy of Natural Sciences, Philadelphia, PA, USA

FMNH: Field Museum of Natural History, Chicago, IL, USA

IFAN: Institut Fondamental d'Afrique Noir, Dakar, Senegal

LACM: Los Angeles County Museum of Natural History, Los Angeles, CA, USA

MACN-Ma: Museo Argentino de Ciências Naturales "Bernardino Rivadavia," Buenos Aires, Argentina

MCZ: Museum of Comparative Zoology, Harvard University, Cambridge, MA, USA

MLP: Museo de La Plata, La Plata, Argentina

MNHN: Muséum National d'Histoire Naturelle, Paris, France

MNHNS: Museo Nacional de Historia Natural, Santiago, Chile

MTQ: Museum of Tropical Queensland, Townsville, Australia

NHMD: Natural History Museum of Denmark, Copenhagen

NHMO: Natural History Museum, Oslo, Norway
NHMUK: Natural History Museum, London, UK (formerly the British Museum of Natural History, $\mathrm{BMNH})$

NSMT: National Science Museum, Tokyo, Japan

PEM: Port Elizabeth Museum, South Africa

QM: Queensland Museum, Brisbane, Australia

RMHNB: Musée Royal d'Histoire Naturelle de Belgique, Brussels, Belgium

RMNH: Naturalis Biodiversity Center, Leiden, Netherlands

SMNS: Staatliches Museum für Naturkunde, Stuttgart, Germany

SWFSC: Southwest Fisheries Science Center (Marine Mammal Synoptic Collection), La Jolla, CA, USA

USNM: National Museum of Natural History (formerly United States National Museum), Smithsonian Institution, Washington, DC, USA

WAM: Western Australian Museum, Perth, Australia

ZAM: South African Museum, Capetown, South Africa

ZMA: Zoological Museum, University of Amsterdam, Netherlands

ZMB: Museum für Naturkunde, Berlin, Germany

ZRC: Zoological Record Collection, National University of Singapore, Singapore 


\section{Appendix E: Glossary of taxonomic nomenclature terms ${ }^{1}$}

Availability: a kind of status that requires that a name must be taken into account as a part of zoological nomenclature. Names that are not available effectively do not exist for the purposes of zoological nomenclature, and cannot enter into synonymy or homonymy, nor can they be used as the names of taxa. For instance, a nomen nudum or any name published before 1758 is considered unavailable.

Basionym: the original name on which a new name is based; also called original combination or protonym.

Emendation: an intentional change in the original spelling of an available name. The change must be consciously made, along with justification for altering the spelling originally used by the taxon author while describing the species. Any other spelling changes are considered to be unjustified. Valid emendations include changes made to correct.

Holotype: a single type specimen upon which the description and name of a new species is based.

Homonym: a name that is spelled the same as another name, which is in common use, but established for a different nominal taxon. A junior homonym cannot be a valid scientific name for a taxon.

Incertae sedis: Latin for "of uncertain placement." This is a term used for a taxonomic group where its broader relationships are unknown or undefined. Alternatively, such groups are frequently referred to as "enigmatic taxa." In a synonymy, such a species name is usually called a nomen dubium.

Indication: in the case of a name proposed before 1931 in which no description or type specimen was provided, a reference to previously published information or an act, which serves to satisfy the conditions of ICZN Articles 10 and 11, making the name available (i.e., not a nomen nudum).

Junior synonym: a name that describes the same taxon as a previously published name; the later published of two or more names based on specimens considered to be conspecific.

\footnotetext{
${ }^{1}$ Definitions adapted from Wikipedia <https://www.wikipedia.org/> and The International Code of Zoological Nomenclature, Fourth Edition. 1999. 366 p. International Trust for Zoological Nomenclature.
}

Lapsus calami: literally "slip of the pen." Similar to lapsus manus (slip of the hand), these terms are used to refer to situations in which an unintended spelling error is made in the use of scientific names in published literature. Although they may be listed in synonymies, these are not considered to be new scientific names, as they are variations that were introduced unintentionally.

Lectotype: a specimen later selected to serve as the single type specimen for species originally described from a set of syntypes. In zoology, a lectotype is a kind of name-bearing type.

Nomen conservandum (or conserved name): a name otherwise unavailable or invalid that the ICZN, by the use of its plenary power (through a vote of the commission members), has enabled to be used as a valid name by removal of the known obstacles to such use.

Nomen correctum: a name with change of spelling, because of incorrect spelling of stem form (rarely used in cetology).

Nomen dubium: a name that is of unknown or doubtful application. It may be impossible to determine whether a specimen belongs to that group or not. This may happen if the original type series is lost or destroyed, or if its name-bearing type is fragmentary or lacking important diagnostic features.

Nomen inquirendum: name that should be investigated (rarely used in cetology).

Nomen novum: new replacement name, proposed as a direct substitute for an invalid existing name.

Nomen nudum: a name that looks like a scientific name, and may have originally been intended to be one, but fails to be one because it has not (or has not yet) been published with an adequate description. Note that names published before 1931 can be accompanied by an "indication" instead of a description, which can simply be a reference to a previously-published description, or even just an illustration. A nomen nudum is a "bare" or "naked" name, and is unavailable. It can be made available if it is published again in a way that meets the criteria of availability; however, if this is done it is attributed to the author who first made it available, not the person who first used it. 
Nomen oblitum: a name shown not to have been used as a valid name within the scientific community since 1899 , and when it is either a senior synonym or a homonym, and when the preferred junior synonym or homonym has been shown to have been in wide use in 25 or more publications in the past few decades. Once formally declared to be a nomen oblitum, the disused name is to be "forgotten." By the same act, the next available name must be declared to be a nomen protectum; from then on, the latter takes precedence.

Nomen protectum: a specific kind of conserved name, which is a junior synonym given precedence over a senior synonym, primarily when the senior name has not been used since 1899, and the junior name is in common use. The older name becomes a nomen oblitum, and the junior name is declared a nomen protectum. A ruling of the ICZN is not required.

Objective synonym: one based on the same type material as another (earlier) named form. Because it is based on type material, it cannot be disputed. This may be species-group taxa of the same rank with the same type specimen, genus-group taxa of the same rank with the same type species, or, if their type species are themselves objective synonyms, family-group taxa with the same type genus.

Paratype: a specimen of an organism that helps define what the scientific name of a species and other taxon actually represents, but it is not the holotype. Often there is more than one paratype, and they are usually held in museum research collections.

Principle of homonymy: this is the principle that the name of each taxon must be unique. Consequently, a name that is a junior homonym of another name must not be used as a valid name.

Principle of priority: this is the principle that the correct formal scientific name for an animal taxon, the valid name, is the oldest available name that applies to it. It is the most important principle - the fundamental guiding precept that preserves zoological nomenclature stability.

Senior synonym: the earliest published name of a taxon. In most cases, this is the specific name applied to the taxon.

Subjective synonym: one of two or more different names that a specialist considers to belong to the same taxon. Because they do not share a type, the synonymy is open to taxonomic judgment, or opinion, they may be disputed or changed.

Syntype: each of a set of type specimens of equal status, upon which the description and name of a new species is based; sometimes called co-types.

Type series: the full set of type specimens of equal status, upon which the description and name of a new species is based.

Validity: a valid name is the correct name for a taxon, i.e., the oldest potentially valid name of a name-bearing type that falls within an author's concept of the taxon. "Potentially valid" means the name must be available, but not otherwise invalid for any other reason, such as being a junior homonym. 


\section{Appendix F: Species names originating in Schreber's Die Säugthiere in Abbildungen}

Several small cetacean species names originated from a 7-volume (plus supplements and plates) semipopular German series on the mammals of the world published between 1774 and 1855 . The reference for the complete set of volumes is:

Schreber, J. C. D., G. A. Goldfuss, and J. A. Wagner. 1774-1855. Die Säugthiere in Abbildungen nach der Natur, mit Beschreibungen, 7 vols. Erlangen, Leipzig, Germany.

The marine mammal species names appear in the final volume of the main 7-volume set (Vol. 7, authored by Wagner and published in 1847, although the title page lists 1846; Fig. F1), but the authorship and dates associated with the names have been confused in the marine mammal literature for many decades. Usually the text volume is cited incorrectly as Wagner (1846). The text of Wagner may have been available to some in 1846, but the volume that contains both text and plates was apparently published in 1847 (Poche, 1911).

This treatise on mammals was started by J. C. D. Schreber in 1774 , but he died in 1810 before it could be completed. Work on the final volume covering pinnipeds and cetaceans (including sirenians) was then undertaken by J. A. Wagner, but he transferred some of the work to Prof. A. F. A. Wiegmann of Berlin, who commissioned preparation of the plates that were to accompany the text. Wiegmann also died (in 1841), before completing his work, and so it eventually fell back to Wagner. Volume 7 was finally published in 1847 with Wagner as sole author, but also listing Schreber as the main author of the series. However, several of the plates for this volume (which are referenced in Volume 7 as part of the same work) were apparently available as early as 1840 in a separate release (Poche, 1911).

As was often the case in the nineteenth century, the plates were issued and distributed at different times. There has been much confusion ever since, due to the fact that in some versions, the plates for marine mammals were not published in the same volume as the text; this is indeed the case in the version in the Biodiversity Heritage Library archives. Plates were probably issued and distributed as they became ready, and with whatever text was being published at the time, thus often appearing out of sequence (see Per- rin, 2001), and this has made determining the specific publication dates for these very challenging. It is clear that some of the relevant plates were seen and referenced by a number of authors at various times between 1840 and 1846. Poche (1911) was only able to identify dates ranges (not exact years) for many of these plates, and I have used the earliest year in the range as the assumed date of publication for each. With this in mind, the actual publication of the plates for Delphinus breviceps, brevimanus, chamissonis, fulvifasciatus, hamatus, loriger, and pseudodelphis dates to 1840 and should be credited to Wiegmann (1840); however, Delphinus carbonarius and roseiventris should be dated as Wiegmann (1844) (Poche, 1911).

In conclusion, there are two published volumes in this series that deal with the delphinoid cetaceans. They should be cited as follows, and are treated as such in the present work:

Wiegmann, A. F. A. 1840, 1844. Die Säugethiere in Abbildungen nach der Natur, mit Beschreibungen (Plates 281-385), 105 plates. Erlangen, Leipzig, Germany. (This is the batch containing the marine mammal plates for Delphinus breviceps, brevimanus, carbonarius, chamissonis, fulvifasciatus, hamatus, loriger, pseudodelphis, and roseiventris [plates 352, 358-362, 368, 369] with no text.)

Wagner, J. A. 1847. Die Säugethiere in Abbildungen nach der Natur, mit Berschreibungen, vol. 7, 427 p. Erlangen, Leipzig, Germany. (This is the marine mammal volume with species text descriptions; the relevant plates are referenced in an appendix herein, and were included in this final version published in 1847.)

\section{Literature cited}

Perrin, W. F.

2001. Stenella attenuata. Mammal. Species 2001 (683):18. https://doi.org/10.1644/1545-1410(2001)683<0001: $\mathrm{SA}>2.0 . \mathrm{CO} ; 2$

Poche, F.

1911. Über den Inhalt und die Erscheinungszeiten der einzelnen Teile, Hefte etc. und die verscheidenen Ausgaben des Schreber'schen Säugetierwerkes (1774-1855). Arch. fur Naturgesch. 77 (Band 1, Suppl. 4):124-183. 


\section{Die \\ S $\mathfrak{a}$ แl $\mathfrak{g}$ t $\mathfrak{b} \mathfrak{i} \mathfrak{e} \mathfrak{r} \mathfrak{e}$ \\ in \\ I(bbilloungen nad) Der গRatur \\ mit $\mathfrak{B e r d} r \mathfrak{c}$ ibungen}

bon

\section{Dr. Johann Ehriftian Daniel von Sdreber,}

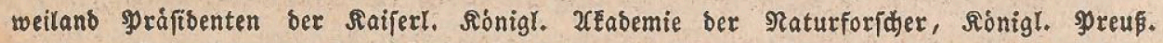

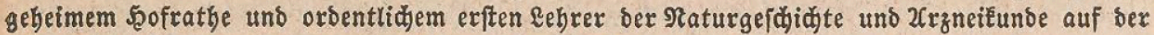

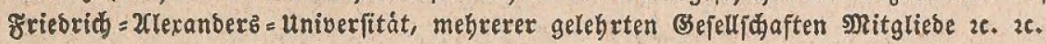

Foxtgefe色t

von

Dr. Sohann 2 noreą $\mathfrak{B a g n e r ,}$

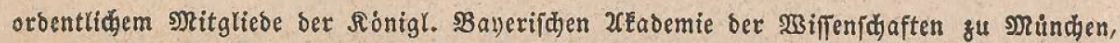
Sprofeffor ber 3oologie an ber subwig = Marimilians = Univerfitát, Eonjervator ber palaeontologijhen Sammlung bes Staates, 2rojunft an ber zoologifds: zootomifoen Sammlung beb Staates zc.

Siebenter Iheil.

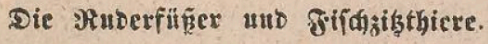

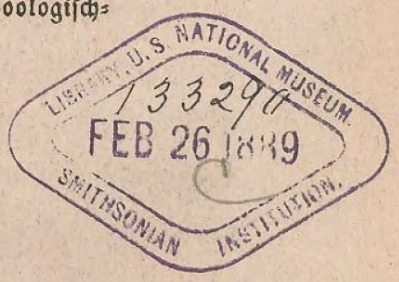

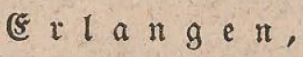

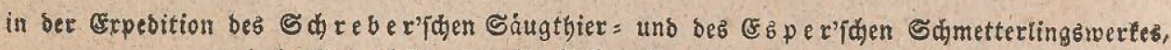

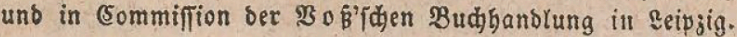

1846.

Figure F1

The title page of Wagner's volume covering the marine mammals (cetaceans, pinnipeds, and sirenians), bearing the date 1846, but actually published in 1847. 


\section{Appendix G: List of named species of dolphins, porpoises, and small whales}

\begin{tabular}{|c|c|c|c|c|c|c|c|c|c|}
\hline Current species & Nominal species & Authority & Page \# & Avail? & Valid? & Status & SPEC & Type dispos. & Notes \\
\hline \multirow[t]{9}{*}{$\begin{array}{l}\text { Narwhal-Monodon } \\
\text { monoceros }\end{array}$} & Monodon monoceros & Linnaeus, 1758 & 75 & $\mathrm{X}$ & $\mathrm{X}$ & Valid name & M MONO & No type & \\
\hline & Ceratodontis ceratodon & Brisson, 1762 & 231 & $\mathrm{X}$ & & Junior synonym & M MONO & No type? & \\
\hline & Monodon narwhal & Blumenbach, 1779 & 142 & $\mathrm{X}$ & & Junior synonym & M MONO & No type? & \\
\hline & Monodon narbval & Borowski, 1781 & 8 & $\mathrm{X}$ & & Junior synonym & M MONO & No type? & \\
\hline & Narwalus vulgaris & Lacépède, 1804 & 142 & $\mathrm{X}$ & & Junior synonym & M MONO & No type? & \\
\hline & Narwalus microcephalus & Lacépède, 1804 & 159 & $\mathrm{X}$ & & Junior synonym & M MONO & No type? & \\
\hline & Narwalus andersonianus & Lacépède, 1804 & 163 & $\mathrm{X}$ & & Junior synonym & M MONO & No type? & \\
\hline & Ceratodon monodon & Pallas, 1811 & 295 & $\mathrm{X}$ & & Junior synonym & M MONO & No type? & \\
\hline & Tachynices megacephalus & Brookes, 1828 & 40 & $\mathrm{X}$ & & Junior synonym & M MONO & No type? & \\
\hline \multirow[t]{15}{*}{$\begin{array}{l}\text { Beluga - Delphin- } \\
\text { apterus leucas }\end{array}$} & Cetus albicans & Brisson, 1762 & 359 & $\mathrm{X}$ & & Nomen oblitum & D LEU & No type & \\
\hline & Delphinus leucas & Pallas, 1776 & $85(\mathrm{fn})$ & $\mathrm{X}$ & $\mathrm{X}$ & Nomen protectum & D LEU & No type & \\
\hline & $D[$ lphinus $]$ phocaena albus & Kerr, 1792 & 363 & $\mathrm{X}$ & & \begin{tabular}{|l|}
$\begin{array}{l}\text { Not a species } \\
\text { name }\end{array}$ \\
\end{tabular} & D LEU & No type? & Subspecies/variety name \\
\hline & Delphinapterus beluga & Lacépède, 1804 & 243 & $\mathrm{X}$ & & Junior synonym & D LEU & $?$ & \\
\hline & Delphinus canadensis & Desmarest, 1822 & 516 & $\mathrm{X}$ & & Junior synonym & D LEU & $?$ & \\
\hline & $\begin{array}{l}\text { Delphinus (Delphinapterus?) } \\
\text { kingii }\end{array}$ & Gray, 1827 & 375 & $\mathrm{X}$ & & Junior synonym & D LEU & NHMUK & \\
\hline & Beluga borealis & Lesson, 1828 & 440 & & & Nomen nudum & D LEU & No type & \\
\hline & Beluga glacialis & Lesson, 1838 & plate 3, fig. 2 & $\mathrm{X}$ & & Junior synonym & D LEU & No type & \\
\hline & Beluga catodon & Gray, 1846 & \begin{tabular}{|l|}
29 \\
\end{tabular} & $\mathrm{X}$ & & Junior synonym & D LEU & NHMUK & \\
\hline & Beluga declivis & Cope, 1865 a & 278 & $\mathrm{X}$ & & Junior synonym & D LEU & MCZ & \\
\hline & Beluga concreta & Cope, $1865 \mathrm{a}$ & 278 & $\mathrm{X}$ & & Junior synonym & D LEU & ANSP & \\
\hline & Beluga rbinodon & Cope, 1865 a & 278 & $\mathrm{X}$ & & Junior synonym & D LEU & ANSP & \\
\hline & Beluga angustata & Cope, 1866 & 293 & $\mathrm{X}$ & & Junior synonym & D LEU & ANSP & \\
\hline & Delphinapterus freimani & Klumov, 1935 & 26 & $\mathrm{X}$ & & Junior synonym & D LEU & $?$ & \\
\hline & Delphinapterus dorofeevi & \begin{tabular}{|l} 
Barabash \& Klumov, \\
1935
\end{tabular} & 24 & $\mathrm{X}$ & & Junior synonym & D LEU & $?$ & \\
\hline \multirow[t]{2}{*}{$\begin{array}{l}\text { Irrawaddy dolphin - } \\
\text { Orcaella brevirostris }\end{array}$} & Phocaena (Orca) brevirostris & Gray, 1866a (Owen in) & 285 & $\mathrm{X}$ & $\mathrm{x}$ & Valid name & O BRE & NHMUK & \\
\hline & Orcaella fluminalis & $\begin{array}{l}\text { Gray, } 1871 \text { (Anderson } \\
\text { in) }\end{array}$ & 80 & $\mathrm{X}$ & & Junior synonym & O BRE & $\begin{array}{l}\text { Indian Muse- } \\
\text { um, Calcutta } \\
\end{array}$ & \\
\hline $\begin{array}{l}\text { Australian snubfin } \\
\text { dolphin - Orcaella } \\
\text { heinsohni }\end{array}$ & Orcaella heinsohni & Beasley et al., 2005 & 378 & $\mathrm{x}$ & $\mathrm{x}$ & Valid name & O HEI & QM & \\
\hline \multirow[t]{12}{*}{$\begin{array}{l}\text { Killer whale-Orcinus } \\
\text { orca }\end{array}$} & [Delphinus] orca & Linnaeus, 1758 & 77 & $\mathrm{x}$ & $\mathrm{x}$ & Valid name & O ORC & No type & $\begin{array}{l}\text { See Kinze (2018) for contro- } \\
\text { versy over this name }\end{array}$ \\
\hline & Delphinus serra & Borowski, 1781 & 38 & $\mathrm{X}$ & & Junior synonym & O ORC & No type & \\
\hline & Physeter microps & Fabricius, 1780 & 44 & $\mathrm{X}$ & & Junior synonym & O ORC & No type & \\
\hline & $D$ [elphinus] gladiator & Bonnaterre, 1789 & 23 & $\mathrm{X}$ & & Junior synonym & O ORC & NHMUK Lost? & No type? \\
\hline & Delphinus duhameli & Lacépède, 1804 & 314 & $\mathrm{X}$ & & Junior synonym & O ORC & No type & \\
\hline & Delphinus grampus & Desmarest, 1817 & 168 & $\mathrm{X}$ & & Junior synonym & O ORC & No type & $\begin{array}{l}\text { Homonym of Delphinus } \\
\text { grampus Gray, } 1846\end{array}$ \\
\hline & Orca capensis & Gray, 1846 & 34 & $\mathrm{X}$ & & Junior synonym & O ORC & NHMUK Lost? & \\
\hline & Delphinus victorini & Grill, 1858 & 21 & $\mathrm{X}$ & & Junior synonym & O ORC & No type? & \\
\hline & Orca eschrichtii & $\begin{array}{l}\text { Eschricht, } 1866 \text { (Rein- } \\
\text { hardt in) }\end{array}$ & 188 & $\mathrm{X}$ & & Junior synonym & O ORC & NHMD & $\begin{array}{l}\text { Eschricht (1866) is Engl. } \\
\text { Transl. of original from } \\
1862\end{array}$ \\
\hline & $\mathrm{O}[$ rca] schlegelii & Lilljeborg, 1866 & 235 & $\mathrm{X}$ & & Junior synonym & O ORC & Bergen Mus & \\
\hline & Orca magellanica & Burmeister, 1866 & 99 & $\mathrm{X}$ & & Junior synonym & O ORC & $\begin{array}{l}\text { MACN-Ma } \\
\text {-Lost? }\end{array}$ & \\
\hline & Orca ater & Scammon, 1869 (Cope in) & 57 & $\mathrm{X}$ & & Junior synonym & O ORC & No type & \\
\hline
\end{tabular}

Table continued 


\begin{tabular}{|c|c|c|c|c|c|c|c|c|c|}
\hline Current species & Nominal species & Authority & Page \# & Avail? & Valid? & Status & SPEC & Type dispos. & Notes \\
\hline & Orca rectipinna & Scammon, 1869 (Cope in) & 55 & $\mathrm{X}$ & & Junior synonym & O ORC & No type & \\
\hline & Orca stenorhyncha & Gray, 1870 & 71 & $\mathrm{X}$ & & Junior synonym & O ORC & NHMUK & \\
\hline & Orca latirostris & Gray, 1870 & 76 & $\mathrm{X}$ & & Junior synonym & O ORC & NHMUK & \\
\hline & Orca pacifica & Gray, 1870 & 76 & $\mathrm{X}$ & & Junior synonym & O ORC & NHMUK & \\
\hline & Orca africana & Gray, 1871 & 91 & $\mathrm{X}$ & & Junior synonym & O ORC & No type? & \\
\hline & Orca tasmanica & Gray, 1871 & 92 & $\mathrm{X}$ & & Junior synonym & O ORC & No type? & \\
\hline & Orca minor & Malm, 1871 & 81 & $\mathrm{X}$ & & Junior synonym & O ORC & Goteborg Mus & \\
\hline & Orca antarctica & Fischer, 1876 & 146 & $\mathrm{X}$ & & Junior synonym & O ORC & No type & \\
\hline & Orcinus nanus & Mikhalev et al., 1981 & 564 & $\mathrm{X}$ & & Junior synonym & O ORC & No type & $\begin{array}{l}\text { Inadequate description; } \\
\text { Mitchell (1985) and Rice } \\
\text { (1998) considered it a } \\
\text { nomen nudum }\end{array}$ \\
\hline & Orcinus mörzer-bruynsus & Heintzelman, 1981 & 24 & & & $\begin{array}{l}\text { Not available } \\
\text { name }\end{array}$ & O ORC & No type & $\begin{array}{l}\text { Based on description in } \\
\text { Mörzer Bryuns (1971); } \\
\text { name not properly } \\
\text { designated }\end{array}$ \\
\hline & Orcinus glacialis & $\begin{array}{l}\text { Berzin \& Vladimirov, } \\
1982\end{array}$ & 31 & $\mathrm{X}$ & & Junior synonym & O ORC & $\begin{array}{l}\text { TINRO Mus } \\
\text {-discarded }\end{array}$ & $\begin{array}{l}\text { Mitchell (1985) considered } \\
\text { it a nomen nudum } \\
\end{array}$ \\
\hline \multirow[t]{15}{*}{$\begin{array}{l}\text { Long-finned pilot } \\
\text { whale - Globicephala } \\
\text { melas }\end{array}$} & Delphinus melas & Traill, 1809 & 31 & $\mathrm{X}$ & $\mathrm{x}$ & Valid name & G MEL & NHMUK & \begin{tabular}{|l|} 
And senior homonym of \\
Delphinus melas Schlegel, \\
1841
\end{tabular} \\
\hline & Delphinus globiceps & G. Cuvier, 1812 & 14 & $\mathrm{x}$ & & Junior synonym & G MEL & $?$ & \\
\hline & Delphinus deductor & Scoresby, 1820 & 496 & $\mathrm{x}$ & & Junior synonym & G MEL & $?$ & \\
\hline & Delphinus grinda & Lyngbye, 1826 & 232 & $\mathrm{x}$ & & Junior synonym & G MEL & No type? & \\
\hline & Delphinus intermedius & Harlan, 1827 & 51 & $\mathrm{X}$ & & Junior synonym & G MEL & $\begin{array}{l}\text { Acad Nat Sci, } \\
\text { Philadelphia }\end{array}$ & $\begin{array}{l}\text { Homonym of Delphinus } \\
\text { intermedius Gray, } 1827\end{array}$ \\
\hline & Phocaena globiceps & Lesson, 1827 & 416 & $\mathrm{x}$ & & Junior synonym & G MEL & NHMUK & $\begin{array}{l}\text { Date is uncertain; pos- } \\
\text { sibly Globicephalus } \\
\text { macrorhynchus }\end{array}$ \\
\hline & Phocaena edwardii & Smith, 1834 & 239 & $\mathrm{x}$ & & Junior synonym & G MEL & \begin{tabular}{|l|} 
NHMUK or \\
Mus Hist Nat \\
Bordeaux \\
\end{tabular} & \\
\hline & Globicephalus conductor & Rapp, 1837 & 34 & $\mathrm{X}$ & & Junior synonym & G MEL & $?$ & \\
\hline & Globicephalus affinis & Gray, 1846 & 32 & $\mathrm{X}$ & & Junior synonym & G MEL & $\begin{array}{l}\text { Hunterian } \\
\text { Museum }\end{array}$ & \\
\hline & Globicephalus svineval & Gray, 1846 & 32 & $\mathrm{x}$ & & Junior synonym & G MEL & $\begin{array}{l}\text { Hunterian } \\
\text { Museum }\end{array}$ & \\
\hline & Delphinus grampus & Gray, 1846 & 32 & & & $\begin{array}{l}\text { Junior } \\
\text { homonym }\end{array}$ & G MEL & $\begin{array}{l}\text { Hunterian } \\
\text { Museum }\end{array}$ & $\begin{array}{l}\text { Unavailable - junior hom- } \\
\text { onym of Delphinus gram- } \\
\text { pus Desmarest, } 1817\end{array}$ \\
\hline & Globiocephalus incrassatus & Gray, 1861 & 309 & $\mathrm{X}$ & & Junior synonym & G MEL & NHMUK & \\
\hline & Globicephalus chiliensis & Philippi, 1895 & 7 & $\mathrm{X}$ & & Junior synonym & G MEL & $\begin{array}{l}\text { NHM, } \\
\text { Santiago }\end{array}$ & \\
\hline & Delphinus melaena & Thomas, 1898 & 99 & $\mathrm{X}$ & & Emendation & G MEL & $?$ & \\
\hline & \begin{tabular}{|l} 
Globicephala \\
leucosagmaphora
\end{tabular} & Rayner, 1939 & 543 & $\mathrm{X}$ & & Junior synonym & G MEL & NHMUK & \\
\hline \multirow[t]{7}{*}{\begin{tabular}{|l} 
Short-finned pilot \\
whale-Globicephala \\
macrorhynchus
\end{tabular}} & $\begin{array}{l}\text { Globicephalus } \\
\text { macrorhynchus }\end{array}$ & Gray, 1846 & 33 & $\mathrm{x}$ & $\mathrm{X}$ & Valid name & GMAC & NHMUK & $\begin{array}{l}\text { Gray later gave macrorhyn- } \\
\text { chus priority over sieboldii }\end{array}$ \\
\hline & Globicephalus sieboldii & Gray, 1846 & 32 & $\mathrm{X}$ & & Junior synonym & G MAC & RMNH & \\
\hline & Delphinus fuscus & Reichenbach, 1846 & 77 & $\mathrm{X}$ & & Junior synonym & GMAC & No type? & \\
\hline & Globicephalus indicus & Blyth, 1852 & 358 & $\mathrm{X}$ & & Junior synonym & G MAC & $\begin{array}{l}\text { Indian Muse- } \\
\text { um, Calcutta }\end{array}$ & \\
\hline & Globicephalus scammonii & \begin{tabular}{|l|} 
Scammon, 1869 (Cope \\
in)
\end{tabular} & 21 & $\mathrm{X}$ & & Junior synonym & G MAC & USNM & \\
\hline & Globiocephalus propinquus & Malm, 1871 & 85 & $\mathrm{X}$ & & Junior synonym & G MAC & Goteborg Mus & \\
\hline & $\begin{array}{l}\text { Globiocephalus } \\
\text { guadaloupensis }\end{array}$ & Gray, 1871 & 84 & & & Nomen nudum & G MAC & MNHN & \\
\hline
\end{tabular}




\begin{tabular}{|c|c|c|c|c|c|c|c|c|c|}
\hline Current species & Nominal species & Authority & Page \# & Avail? & Valid? & Status & SPEC & Type dispos. & Notes \\
\hline & Globicephalus sibo & Gray, 1871 & 85 & $\mathrm{X}$ & & Junior synonym & GMAC & No type? & \\
\hline & Globicephalus brachypterus & Cope, 1876 & 129 & $\mathrm{X}$ & & Junior synonym & G MAC & \begin{tabular}{|l} 
Acad Nat Sci, \\
Philadelphia
\end{tabular} & \\
\hline \multirow[t]{6}{*}{$\begin{array}{l}\text { False killer whale - } \\
\text { Pseudorca crassidens }\end{array}$} & Delphinus dalippus & $\begin{array}{l}\text { Rafinesque Schmaltz, } \\
1814\end{array}$ & 13 & $\mathrm{x}$ & & $\begin{array}{l}\text { Senior } \\
\text { synonym }\end{array}$ & P CRA & No type & $\begin{array}{l}\text { Name needs to be declared } \\
\text { a nomen oblitum }\end{array}$ \\
\hline & Phocaena crassidens & Owen, 1846 & 516 & $\mathrm{X}$ & $\mathrm{X}$ & Valid name & P CRA & Lost & \\
\hline & Orca meridionalis & Flower, 1864 & 420 & $\mathrm{X}$ & & Junior synonym & P CRA & NHMUK & \\
\hline & Orca destructor & Cope, 1866 & 293 & $\mathrm{X}$ & & Junior synonym & P CRA & USNM & \\
\hline & Globicephalus grayi & Burmeister, 1868 & 367 & $\mathrm{X}$ & & Junior synonym & P CRA & $\begin{array}{l}\text { MACN-Ma } \\
\text {-Lost? }\end{array}$ & \\
\hline & Psendorca? mediterranea & Giglioli, 1882 & 289 & $\mathrm{X}$ & & Junior synonym & P CRA & $\begin{array}{l}\text { Florence Mus; } \\
\text { Zool. Mus. } \\
\text { Palermo } \\
\end{array}$ & \\
\hline \multirow[t]{3}{*}{$\begin{array}{l}\text { Pygmy killer whale - } \\
\text { Feresa attenuata }\end{array}$} & Delphinus intermedius & Gray, 1827 & 376 & $\mathrm{X}$ & & Junior homonym & F ATT & NHMUK & $\begin{array}{l}\text { Junior homonym of } \\
\text { Delphinus intermedius } \\
\text { Harlan, } 1827\end{array}$ \\
\hline & Feresa attenuata & Gray, 1874 & 184 & $\mathrm{X}$ & $\mathrm{X}$ & Valid name & F ATT & NHMUK & \\
\hline & Feresa occulta & Jones \& Packard, 1956 & 167 & $\mathrm{X}$ & & Junior synonym & F ATT & No type & \\
\hline \multirow[t]{5}{*}{$\begin{array}{l}\text { Melon-headed whale - } \\
\text { Peponocephala electra }\end{array}$} & Lagenorhynchus electra & Gray, 1846 & 35 & $\mathrm{X}$ & $\mathrm{X}$ & Valid name & P ELE & NHMUK & \\
\hline & Lagenorhynchus asia & Gray, 1846 & 35 & $\mathrm{X}$ & & Junior synonym & P ELE & NHMUK & \\
\hline & Phocoena pectoralis & Peale, 1849 & 32 & $\mathrm{X}$ & & Junior synonym & P ELE & USNM & \\
\hline & $\begin{array}{l}\text { Delphinus (Lageno- } \\
\text { rhynchus) fusiformis }\end{array}$ & Owen, 1866 & 22 & $\mathrm{X}$ & & \begin{tabular}{|l} 
Junior \\
synonym
\end{tabular} & P ELE & NHMUK & \\
\hline & Electra obtusa & Gray, 1868 & 7 & $\mathrm{X}$ & & Junior synonym & P ELE & No type & \\
\hline \multirow[t]{12}{*}{$\begin{array}{l}\text { Risso's dolphin - } \\
\text { Grampus griseus }\end{array}$} & Delphinus griseus & G. Cuvier, 1812 & 14 & $\mathrm{X}$ & $\mathrm{X}$ & Valid name & G GRI & MNHN & \\
\hline & [Delphinus] aires & G. Cuvier, 1812 & 12, P.1 & $\mathrm{X}$ & & Junior synonym & G GRI & No type? & \\
\hline & Delphinus rissoanus & Desmarest, 1822 & 519 & $\mathrm{X}$ & & Junior synonym & G GRI & No type? & \\
\hline & $D$ [elphinus] risso & Risso, 1826 & 23 & $\mathrm{X}$ & & Junior synonym & G GRI & No type? & \\
\hline & Globicephalus rissii & Hamilton, 1837 & 219 & $\mathrm{X}$ & & Junior synonym & G GRI & No type? & \\
\hline & Grampus cuvieri & Gray, 1846 & 31 & $\mathrm{X}$ & & Junior synonym & G GRI & No type & \\
\hline & Grampus sakamata & Gray, 1846 & 31 & $\mathrm{X}$ & & Junior synonym & G GRI & MNHN? & \\
\hline & Grampus richardsoni & Gray, 1850 & 85 & $\mathrm{X}$ & & Junior synonym & G GRI & NHMUK & \\
\hline & Grampus stearnsii & Dall, 1873 & 13 & $\mathrm{X}$ & & Junior synonym & G GRI & USNM & \\
\hline & Grampus sowerbianus & Fischer, 1881 & 210 & $\mathrm{x}$ & & Junior synonym & G GRI & Bordeaux Mus. & \\
\hline & Grampidelphis kuzira & $\begin{array}{l}\text { Iredale \& Troughton, } \\
1933\end{array}$ & 34 & $\mathrm{X}$ & & Junior synonym & G GRI & No type? & \\
\hline & Grampidelphis exilis & $\begin{array}{l}\text { Iredale \& Troughton, } \\
1933\end{array}$ & 32 & $\mathrm{X}$ & & Junior synonym & G GRI & $\mathrm{AM}$ & \\
\hline \multirow[t]{3}{*}{$\begin{array}{l}\text { Tucuxi - Sotalia } \\
\text { fluviatilis }\end{array}$} & Delphinus fluviatilis & $\begin{array}{l}\text { Gervais, } 1853 \text { (Gervais } \\
\text { \& Deville in) }\end{array}$ & 148 & $\mathrm{X}$ & $\mathrm{X}$ & Valid name & S FLU & MNHN & \\
\hline & Delphinus pallidus & Gervais, 1855 & 94 & $\mathrm{X}$ & & Junior synonym & S FLU & MNHN & \\
\hline & Steno tucuxi & Gray, 1856 & 158 & $\mathrm{X}$ & & Junior synonym & S FLU & NHMUK & \\
\hline \multirow[t]{2}{*}{$\begin{array}{l}\text { Guiana dolphin - } \\
\text { Sotalia guianensis }\end{array}$} & Delphinus guianensis & P. J. Van Beneden, 1864 & 27 & $\mathrm{X}$ & $\mathrm{X}$ & Valid name & S GUI & MRHNB & \\
\hline & Sotalia brasiliensis & E. Van Beneden, 1875 & 8 & $\mathrm{X}$ & & Junior synonym & S GUI & $\begin{array}{l}\text { Louvain Mus., } \\
\text { Brussels }\end{array}$ & \\
\hline \multirow[t]{7}{*}{$\begin{array}{l}\text { Rough-toothed dolphin } \\
\text {-Steno bredanensis }\end{array}$} & Delphinus bredanensis & Lesson, 1828 & 206 & $\mathrm{X}$ & $\mathrm{X}$ & Valid name & S BRE & $\begin{array}{l}\text { Ghent Univ. } \\
\text { Mus.; syntypes } \\
\text { at MNHN? }\end{array}$ & $\begin{array}{l}\text { See Smeenk (2018) for } \\
\text { details }\end{array}$ \\
\hline & Delphinus chamissonis & Wiegmann, 1840 & Pl. 359 & $\mathrm{X}$ & & Junior synonym & S BRE & No type & No description \\
\hline & Delphinus planiceps & Schlegel, 1841b & 27 & $\mathrm{X}$ & & Junior synonym & S BRE & RMNH, lost? & \\
\hline & Delphinus reinwardtii & Schlegel, 1841b & 27 & $\mathrm{X}$ & & Junior synonym & S BRE & RMNH & \\
\hline & Delphinus compressus & Gray, 1843 & 105 & & & Nomen nudum & S BRE & NHMUK & \\
\hline & Delphinus chamissonis & Wagner, 1847 & 366, pl. 359 & $\mathrm{X}$ & & Junior synonym & S BRE & $?$ & \\
\hline & Steno compressus & Gray, 1850 & 129 & $\mathrm{X}$ & & Junior synonym & S BRE & NHMUK & \\
\hline
\end{tabular}




\begin{tabular}{|c|c|c|c|c|c|c|c|c|c|}
\hline Current species & Nominal species & Authority & Page \# & Avail? & Valid? & Status & SPEC & Type dispos. & Notes \\
\hline & $\begin{array}{l}\text { Delphinus (Steno) } \\
\text { perspicillatus }\end{array}$ & Peters, 1877 & 360 & $\mathrm{X}$ & & Junior synonym & S BRE & ZMB, Berlin & \\
\hline \multirow[t]{3}{*}{$\begin{array}{l}\text { Indo-Pacific hump- } \\
\text { back dolphin - Sousa } \\
\text { chinensis }\end{array}$} & Delphinus chinensis & Osbeck, 1765 & 337 & $\mathrm{X}$ & $\mathrm{X}$ & Valid name & S CHI & $\begin{array}{l}\text { No type; } \\
\text { neotype at } \\
\text { NHMUK }\end{array}$ & \\
\hline & Sotalia borneensis & Lydekker, 1901 & 88 & $\mathrm{X}$ & & Junior synonym & S CHI & NHMUK & \\
\hline & Sousa huangi & Wang, 1999 & 309 & $\mathrm{X}$ & & Junior synonym & S CHI & No type & \\
\hline \multirow{4}{*}{$\begin{array}{l}\text { Indian Ocean hump- } \\
\text { back dolphin - Sousa } \\
\text { plumbea }\end{array}$} & Delphinus plumbeus & G. Cuvier, 1829 & 288 & $\mathrm{x}$ & $\mathrm{X}$ & Valid name & SPLU & MNHN & \\
\hline & $\begin{array}{l}\text { Delphinus (Steno?) } \\
\text { lentiginosus }\end{array}$ & Owen, 1866 & 20 & $\mathrm{x}$ & & Junior synonym & SPLU & NHMUK & \\
\hline & Sotalia fergusoni & Lydekker, 1904 & 411 & $\mathrm{X}$ & & Junior synonym & SPLU & NHMUK & \\
\hline & Stenopontistes zambezicus & Miranda-Ribiero, 1936 & 3 & $\mathrm{X}$ & & Junior synonym & SPLU & \begin{tabular}{|l|} 
Mus. Nac., \\
Rio de Janiero \\
\end{tabular} & \\
\hline $\begin{array}{l}\text { Atlantic humpback } \\
\text { dolphin - Sousa teuszii }\end{array}$ & Sotalia teuszii & Kükenthal, 1892 & 442 & $\mathrm{X}$ & $\mathrm{x}$ & Valid name & STEU & NHMUK & \\
\hline \multirow{2}{*}{$\begin{array}{l}\text { Australian humpback } \\
\text { dolphin - Sousa } \\
\text { sabulensis }\end{array}$} & Sousa queenslandensis & Gaskin, 1972 & 124 & & & Nomen nudum & SSAH & No type & Name unavailable \\
\hline & Sousa sabulensis & $\begin{array}{l}\text { Jefferson \& Rosenbaum, } \\
2014\end{array}$ & 1526 & $\mathrm{x}$ & $\mathrm{X}$ & Valid name & SSAH & MTQ & \\
\hline \multirow[t]{17}{*}{$\begin{array}{l}\text { Common bottlenose } \\
\text { dolphin - Tursiops } \\
\text { truncatus }\end{array}$} & Delphinus tursio & Gunnerus, 1768 & 111 & $\mathrm{X}$ & & Nomen oblitum & T TRU & $\begin{array}{l}\text { Town Hall of } \\
\text { Gdansk -Lost? }\end{array}$ & $\begin{array}{l}\text { Proposed by Kinze (2018) as } \\
\text { valid name for common BND; } \\
\text { homonym of Delphinus tursio } \\
\text { Fabricius, } 1780\end{array}$ \\
\hline & Delphinus nesarnack & Lacépède, 1804 & 307 & $\mathrm{X}$ & & Nomen oblitum & T TRU & $\begin{array}{l}\text { Vet School of } \\
\text { Alford? }\end{array}$ & Suppressed by ICZN \\
\hline & Delphinus truncatus & Montagu, 1821 & 75 & $\mathrm{X}$ & $\mathrm{X}$ & $\begin{array}{l}\text { Nomen } \\
\text { conservandum }\end{array}$ & T TRU & NHMUK & Retained by ICZN \\
\hline & Delphinus compressicauda & Lesson, 1828 & 272 & $\mathrm{X}$ & & Junior synonym & T TRU & NHMUK & \\
\hline & Delphinus eurynome & Gray, 1846 & 38 & $\mathrm{X}$ & & Junior synonym & T TRU & NHMUK & \\
\hline & Delphinus metis [No. 1] & Gray, 1846 & 38 & $\mathrm{x}$ & & Junior synonym & T TRU & NHMUK & $\begin{array}{l}\text { Not Delphinus metis } \\
{[\text { [No. 2], for which it is a }} \\
\text { homonym }\end{array}$ \\
\hline & Delphinus cymodoce & Gray, 1846 & 38 & $\mathrm{X}$ & & Junior synonym & T TRU & NHMUK & Or Burmiester, 1867 \\
\hline & Delphinus tursio obtusus & Schlegel, 1862 & Pl. 13 & $\mathrm{X}$ & & $\begin{array}{l}\text { Not a species } \\
\text { name }\end{array}$ & T TRU & RMNH & Subspecies/variety name \\
\hline & Delphinus erebennus & Cope, 1865 a & 281 & $\mathrm{X}$ & & Junior synonym & T TRU & ANSP & \\
\hline & Tursiops gillii & Dall, 1873 & 13 & $\mathrm{X}$ & & Junior synonym & T TRU & USNM & \\
\hline & Tursiops subridens & True, 1884 & 16 & $\mathrm{X}$ & & Junior synonym & T TRU & USNM & \\
\hline & Tursiops parvimanus & P. J. Van Beneden, 1886 & 100 & & & Nomen nudum & T TRU & NHMD & \\
\hline & Tursiops parvimanus & Lütken, 1887 & 20 & & & Junior synonym & T TRU & NHMD & \\
\hline & Tursiops dawsoni & Lydekker, 1909 & 802 & $\mathrm{X}$ & & Junior synonym & T TRU & NHMD & \\
\hline & Tursiops gephyreus & Lahille, 1909 & 347 & $\mathrm{X}$ & & Junior synonym & T TRU & MACN-Ma & \\
\hline & Tursiops nииапи & Andrews, 1911a & 233 & $\mathrm{X}$ & & Junior synonym & T TRU & AMNH & \\
\hline & Tursiops mangeanus & $\begin{array}{l}\text { Iredale \& Troughton, } \\
1934\end{array}$ & 68 & $\mathrm{X}$ & & Junior synonym & T TRU & QVMAG & \\
\hline \multirow[t]{6}{*}{$\begin{array}{l}\text { Indo-Pacific bottlenose } \\
\text { dolphin-Tursiops } \\
\text { aduncus }\end{array}$} & Delphinus aduncus & $\begin{array}{l}\text { Hemprich \& Ehrenberg, } \\
1832\end{array}$ & on p. 6 of & $\mathrm{X}$ & $\mathrm{X}$ & Valid name & T ADU & ZMB, Berlin & Pages are un-numbered \\
\hline & Delphinus hamatus & Wiegmann, 1840 & Pl. 369 & $\mathrm{X}$ & & Junior synonym & T ADU & No type & No description \\
\hline & Delphinus abusalam & Rüppell, 1842 & 140 & $\mathrm{X}$ & & Junior synonym & T ADU & \begin{tabular}{|l|} 
Senckenberg \\
Mus \\
\end{tabular} & \\
\hline & Delphinus hamatus & Wagner, 1847 & 324, pl. 369 & $\mathrm{X}$ & & Junior synonym & T ADU & $?$ & \\
\hline & Tursiops catalania & Gray, 1862 & 143 & $\mathrm{X}$ & & Junior synonym & T ADU & NHMUK & \\
\hline & \begin{tabular}{|l} 
Delphinus (Steno?) \\
maculiventer
\end{tabular} & Owen, 1866 & 21 & $\mathrm{X}$ & & Junior synonym & T ADU & NHMUK? & \\
\hline
\end{tabular}

Table continued 


\begin{tabular}{|c|c|c|c|c|c|c|c|c|c|}
\hline Current species & Nominal species & Authority & Page \# & Avail? & Valid? & Status & SPEC & Type dispos. & Notes \\
\hline & Delphinus (Steno?) gadamu & Owen, 1866 & 17 & $\mathrm{X}$ & & Junior synonym & T ADU & NHMUK & \\
\hline & Delphinus salam & P. J. Van Beneden, 1886 & 111 & $\mathrm{X}$ & & Junior synonym & T ADU & $?$ & \\
\hline & Tursiops fergusoni & Lydekker, 1903 & 41 & $\mathrm{X}$ & & Junior synonym & T ADU & NHMUK? & \\
\hline & Tursiops australis & $\begin{array}{l}\text { Charlton-Robb et al., } \\
2011\end{array}$ & 13 & $\mathrm{x}$ & & Junior synonym & T TRU & QVMAG & \\
\hline \multirow[t]{5}{*}{$\begin{array}{l}\text { Spinner dolphin- } \\
\text { Stenella longirostris }\end{array}$} & Delphinus longirostris & Gray, 1828 & 1 & $\mathrm{x}$ & $\mathrm{x}$ & Valid name & SLON & RMNH & $\begin{array}{l}\text { Homonym of Delphinus } \\
\text { longirostris G. Cuvier, } 1829\end{array}$ \\
\hline & Delphinus roseiventris & Wiegmann, 1844 & Pl. 360 & $\mathrm{x}$ & & Junior synonym & SLON & No holotype & $\begin{array}{l}\text { No description; neotype in } \\
\text { MNHN }\end{array}$ \\
\hline & Delphinus alope & Gray, 1846 & Pl. 32 & $\mathrm{X}$ & & Junior synonym & S LON & NHMUK & \\
\hline & Delphinus microps & Gray, 1846 & 42 & $\mathrm{X}$ & & Junior synonym & SLON & NHMUK & \\
\hline & Delphinus stenorhynchus & Gray, 1866a & 396 & $\mathrm{x}$ & & Junior synonym & SLON & NHMUK & \\
\hline \multirow{13}{*}{$\begin{array}{l}\text { Pantropical spotted } \\
\text { dolphin - Stenella } \\
\text { attenuata }\end{array}$} & Delphinus velox & G. Cuvier, 1829 & 288 & $\mathrm{x}$ & & Nomen oblitum & S ATT & MNHN & Supressed by ICZN \\
\hline & Delphinus brevimanus & Wiegmann, 1840 & Pl. 361 & $\mathrm{X}$ & & Nomen oblitum & SATT & No type & No description \\
\hline & Delphinus psendodelphis & Wiegmann, 1840 & Pl. 358 & $\mathrm{X}$ & & Nomen oblitum & S ATT & ZMB, Berlin & No description \\
\hline & Delphinus pseudodelphis & Schlegel, 1841b & 22 & $\mathrm{X}$ & & Nomen oblitum & S ATT & No type/Lost? & Supressed by ICZN \\
\hline & Delphinus attenuatus & Gray, 1843a & 105 & & & Nomen nudum & S ATT & No type? & \\
\hline & Steno attenuatus & Gray, 1846 & 44 & $\mathrm{x}$ & $\mathrm{x}$ & $\begin{array}{l}\text { Nomen } \\
\text { conservandum }\end{array}$ & S ATT & NHMUK & Retained by ICZN \\
\hline & Delphinus albirostratus & Peale, 1849 & 34 & $\mathrm{X}$ & & Junior synonym & S ATT & USNM-Lost & \\
\hline & Delphinus? microbrachium & Gray, 1850 & 119 & $\mathrm{X}$ & & Junior synonym & S ATT & MNHN & $\begin{array}{l}\text { Considered a nomen obli- } \\
\text { tum by Perrin }\end{array}$ \\
\hline & Delphinus brevimanus & $\begin{array}{l}\text { Jacquinot \& Pucheran, } \\
1853\end{array}$ & 38 & $\mathrm{x}$ & & Nomen oblitum? & S ATT & MNHN & Supressed by ICZN \\
\hline & Steno capensis & Gray, $1865 \mathrm{a}$ & 522 & $\mathrm{x}$ & & Junior synonym & S ATT & $\begin{array}{l}\text { NHMUK } \\
\text { (maybe a cast) }\end{array}$ & \\
\hline & Clymene punctata & Gray, $1866 c$ & 738 & $\mathrm{X}$ & & Junior synonym & S ATT & Lost & \\
\hline & Steno consimilis & Malm, 1871 & 104 & $\mathrm{X}$ & & Junior synonym & S ATT & \begin{tabular}{|l} 
Tech Inst, \\
Sweden
\end{tabular} & \\
\hline & Prodelphinus graffmani & Lönnberg, 1934 & 1 & $\mathrm{x}$ & & Junior synonym & S ATT & $\begin{array}{l}\text { State MusNH, } \\
\text { Stockholm }\end{array}$ & \\
\hline \multirow[t]{4}{*}{$\begin{array}{l}\begin{array}{l}\text { Atlantic spotted dol- } \\
\text { phin - Stenella frontalis }\end{array} \\
\end{array}$} & Delphinus frontalis & G. Cuvier, 1829 & 288 & $\mathrm{x}$ & $\mathrm{x}$ & Valid name & SFRO & MNHN & \\
\hline & Delphinus froenatus & F. Cuvier, 1836 & 155 & $\mathrm{X}$ & & Junior synonym & SFRO & MNHN & \\
\hline & Delphinus doris & Gray, 1846 & 39 & $\mathrm{X}$ & & Junior synonym & SFRO & NHMUK & \\
\hline & Delphinus plagiodon & Cope, 1866 & 296 & $\mathrm{X}$ & & Junior synonym & SFRO & USNM & \\
\hline \multirow[t]{15}{*}{$\begin{array}{l}\text { Striped dolphin - } \\
\text { Stenella coeruleoalba }\end{array}$} & Delphinus coeruleo-albus & Meyen, 1833 & 609 & $\mathrm{x}$ & $\mathrm{X}$ & Valid name & $S \mathrm{COE}$ & $\begin{array}{l}\text { ZMB, } \\
\text { Berlin }\end{array}$ & \\
\hline & Delphinus styx & Gray, 1846 & 39 & $\mathrm{X}$ & & Junior synonym & SCOE & Lost? & \\
\hline & Delphinus euphrosyne & Gray, 1846 & 40 & $\mathrm{X}$ & & Junior synonym & S COE & NHMUK & \\
\hline & Delphinus holböllii & Nilsson, 1847 & 595 & $\mathrm{X}$ & & Junior synonym & S COE & ZMA, NHMD & \\
\hline & Delphinus lateralis & Peale, 1849 & 35 & $\mathrm{x}$ & & Junior synonym & S COE & Lost & \\
\hline & Delphinus tethyos & Gervais, 1853 & 150 & $\mathrm{X}$ & & Junior synonym & S COE & MNHN & \\
\hline & Delphinus marginatus & $\begin{array}{l}\text { Desmarest, } 1856 \text { (Du- } \\
\text { vernoy in) }\end{array}$ & 284 & $\mathrm{x}$ & & Junior synonym & $S \mathrm{COE}$ & MNHN? & \begin{tabular}{|l|l|} 
Homonym of Delphinus \\
marginatus Lafont, 1868
\end{tabular} \\
\hline & Delphinus mediterraneus & Loche, 1860 & 475 & $\mathrm{X}$ & & Junior synonym & S COE & MNHN & \\
\hline & Delphinus asthenops & Cope, $1865 b$ & 201 & $\mathrm{X}$ & & Junior synonym & S COE & ANSP & \\
\hline & Delphinus crotaphiscus & Cope, $1865 b$ & 203 & $\mathrm{X}$ & & Junior synonym & S COE & Lost & \\
\hline & Tursio dorcides & Gray, 1866a & 400 & $\mathrm{X}$ & & Junior synonym & S COE & NHMUK & \\
\hline & Clymenia euphrosynoides & Gray, 1868a & 6 & $\mathrm{X}$ & & Junior synonym & S COE & No type & \\
\hline & Clymenia burmeisteri & Malm, 1871 & 63 & $\mathrm{x}$ & & Junior synonym & $S \mathrm{COE}$ & $\begin{array}{l}\text { Rijkmuseum, } \\
\text { Stockholm }\end{array}$ & \\
\hline & Clymenia novae-zealandiae & Hector, 1873 & 159 & $\mathrm{X}$ & & Junior synonym & S COE & $?$ & \\
\hline & Delphinus amphitriteus & Philippi, 1893 & 7 & $\mathrm{X}$ & & Junior synonym & S COE & $?$ & \\
\hline
\end{tabular}




\begin{tabular}{|c|c|c|c|c|c|c|c|c|c|}
\hline Current species & Nominal species & Authority & Page \# & Avail? & Valid? & Status & SPEC & Type dispos. & Notes \\
\hline \multirow[t]{4}{*}{$\begin{array}{l}\text { Clymene dolphin- } \\
\text { Stenella clymene }\end{array}$} & Delphinus metis [No. 2] & Gray, 1846 & 39 & $\mathrm{X}$ & & Junior homonym & S CLY & No type & \begin{tabular}{|l|} 
Junior homonym of Del- \\
phinus metis [No. 1] Gray, \\
1846
\end{tabular} \\
\hline & Delphinus clymene & Gray, 1847 & 35 & & & Nomen nudum & $S \mathrm{CLY}$ & NHMUK & \\
\hline & Delphinus clymene & Gray, 1850 & 115 & $\mathrm{X}$ & $\mathrm{X}$ & Valid name & SCLY & NHMUK & \\
\hline & Clymene normalis & Gray, 1866a & 214 & $\mathrm{X}$ & & Junior synonym & S CLY & No type & \\
\hline \multirow[t]{24}{*}{$\begin{array}{l}\text { Common dolphin- } \\
\text { Delphinus delphis }\end{array}$} & Delphinus delphis & Linnaeus, 1758 & 77 & $\mathrm{X}$ & $\mathrm{X}$ & Valid name & D DEL & No type & \\
\hline & Delphinus vulgaris & Lacépède, 1804 & 250 & $\mathrm{X}$ & & Junior synonym & D DEL & No type? & \\
\hline & Delphinus capensis & Gray, 1828 & 2 & $\mathrm{X}$ & & Junior synonym & D DEL & NHMUK & \\
\hline & Delphinus longirostris & G. Cuvier, 1829 & 288 & $\mathrm{X}$ & & Junior synonym & D DEL & MNHN & $\begin{array}{l}\text { Homonym of Delphinus } \\
\text { longirostris Gray, } 1828\end{array}$ \\
\hline & Delphinus novae-zelandiae & Quoy \& Gaimard, 1830 & 149 & $\mathrm{X}$ & & Junior synonym & D DEL & ? & \\
\hline & Delphinus loriger & Wiegmann, 1840 & Pl. 362 & $\mathrm{X}$ & & Junior synonym & D DEL & ZMB, Berlin & No description \\
\hline & Delphinus zelandae & Gray, 1843b & 183 & $\mathrm{X}$ & & Junior synonym & D DEL & No type & \\
\hline & Delphinus janira & Gray, 1846 & 41 & $\mathrm{X}$ & & Junior synonym & D DEL & NHMUK & \\
\hline & Delphinus forsteri & Gray, 1846 & 42 & $\mathrm{X}$ & & Junior synonym & D DEL & No type? & \\
\hline & Delphinus loriger & Wagner, 1847 & 335 , pl. 362 & $\mathrm{X}$ & & Junior synonym & D DEL & No type? & \\
\hline & Delphinus albimanus & Peale, 1849 & 33 & $\mathrm{X}$ & & Junior synonym & D DEL & USNM & \\
\hline & Delphinus fulvifasciatus & \begin{tabular}{|l} 
Jacquinot \& Pucheran, \\
1853
\end{tabular} & 37 & $\mathrm{X}$ & & Junior synonym & D DEL & MNHN & \\
\hline & Delphinus frithii & Blyth, 1859 & 492 & $\mathrm{X}$ & & Junior synonym & D DEL & $\begin{array}{l}\text { Indian Muse- } \\
\text { um, Calcutta; } \\
\text { Lost }\end{array}$ & Probably long-beaked form \\
\hline & Delphinus algeriensis & Loche, 1860 & 474 & $\mathrm{X}$ & & Junior synonym & D DEL & \begin{tabular}{|l|}
$\mathrm{NH}$ \\
MusAlgiers \\
\end{tabular} & \\
\hline & Delphinus moorei & Gray, 1866b & 736 & $\mathrm{X}$ & & Junior synonym & D DEL & $\begin{array}{l}\text { Liverpool Free } \\
\text { Mus }\end{array}$ & \\
\hline & Delphinus walkeri & Gray, $1866 b$ & 737 & $\mathrm{X}$ & & Junior synonym & D DEL & $\begin{array}{l}\text { Liverpool Free } \\
\text { Mus }\end{array}$ & \\
\hline & Delphinus microps & Burmeister, 1866 & 101 & $\mathrm{X}$ & & Junior synonym & D DEL & $\begin{array}{l}\text { MACN-Ma } \\
\text {-Lost? }\end{array}$ & \\
\hline & Delphinus major & Gray, 1866a & 396 & $\mathrm{X}$ & & Junior synonym & D DEL & NHMUK & \\
\hline & Delphinus poтеegra & Owen, 1866 & 23 & $\mathrm{x}$ & & Junior synonym & D DEL & NHMUK & \\
\hline & Delphinus bairdii & Dall, 1873 & 12 & $\mathrm{X}$ & & Junior synonym & D DEL & $\begin{array}{l}\text { USNM - Lost; } \\
\text { neotype at } \\
\text { LACM }\end{array}$ & \\
\hline & $\begin{array}{l}\text { Lagenorhynchus de } \\
\text { castelnau }\end{array}$ & Van Beneden, 1873 & 38 & & & $\begin{array}{l}\text { Not a scientific } \\
\text { name }\end{array}$ & D DEL & No type? & \\
\hline & E[udelphinus] tasmaniensis & $\begin{array}{l}\text { Van Beneden \& Gervais, } \\
1880\end{array}$ & 604 & $\mathrm{X}$ & & Junior synonym & D DEL & MNHN -lost? & $\begin{array}{l}\text { Heyning \& Perrin } 1994 \\
\text { considered it a nomen } \\
\text { dubium }\end{array}$ \\
\hline & Delphinus dussumieri & Blanford, 1891 & 588 & & & $\begin{array}{l}\text { Junior } \\
\text { homonym }\end{array}$ & D DEL & No type & $\begin{array}{l}\text { Unavailable, as a junior } \\
\text { homonym of Delphinus } \\
\text { dussumieri Fischer, } 1829\end{array}$ \\
\hline & Delphinus tropicalis & van Bree, 1971c & 345 & $\mathrm{X}$ & & Junior synonym & D DEL & No type & $\begin{array}{l}\text { Delphinus delphis tropicalis } \\
\text { subspecies }\end{array}$ \\
\hline $\begin{array}{l}\text { Fraser's dolphin - } \\
\text { Lagenodelphis hosei }\end{array}$ & Lagenodelphis hosei & Fraser, 1956 & 496 & $\mathrm{X}$ & $\mathrm{X}$ & Valid name & L HOS & NHMUK & \\
\hline \multirow[t]{3}{*}{$\begin{array}{l}\text { White-beaked dolphin } \\
\text { - Lagenorbynchus } \\
\text { albirostris }\end{array}$} & Lagenorhynchus albirostris & Gray, 1846 & 84 & $\mathrm{X}$ & $\mathrm{X}$ & Valid name & L ALB & NHMUK? & \\
\hline & Delphinus pseudotursio & Reichenbach, 1846 & $\begin{array}{l}\text { Pl. 24, } \\
\text { Fig. } 76\end{array}$ & $\mathrm{X}$ & & Junior synonym & L ALB & No type & \\
\hline & Delphinus ibsenii & Eschricht, 1846 & 297 & $\mathrm{x}$ & & Junior synonym & L ALB & NHMD & \\
\hline $\begin{array}{l}\text { Atlantic white-sided } \\
\text { dolphin - Lagenorhyn- } \\
\text { chus acutus }\end{array}$ & Delphinus (Grampus) acutus & Gray, 1828 & 2 & $\mathrm{X}$ & $\mathrm{X}$ & Valid name & L ACU & RMNH & \\
\hline
\end{tabular}




\begin{tabular}{|c|c|c|c|c|c|c|c|c|c|}
\hline Current species & Nominal species & Authority & Page \# & Avail? & Valid? & Status & SPEC & Type dispos. & Notes \\
\hline & Delphinus eschrichtii & Schlegel, 1841b & 23 & $\mathrm{X}$ & & Junior synonym & L ACU & RMNH & \\
\hline & Delphinus lencopleurus & Rasch, 1843 & 100 & $\mathrm{X}$ & & Junior synonym & L ACU & $\begin{array}{l}\text { RMNH, } \\
\text { NHMO } \\
\end{array}$ & \\
\hline & Lencopleurus arcticus & Gray, 1868a & 7 & $\mathrm{X}$ & & Junior synonym & L ACU & No type? & \\
\hline & $\begin{array}{l}\text { Lagenorhynchus } \\
\text { perspicillatus }\end{array}$ & Cope, 1876 & 136 & $\mathrm{X}$ & & Junior synonym & L ACU & USNM & \\
\hline & Lagenorhynchus gubernator & Cope, 1876 & 138 & $\mathrm{X}$ & & Junior synonym & L ACU & Cast in USNM & \\
\hline & $\begin{array}{l}\text { L[agenorhynchus] } \\
\text { bombifrons }\end{array}$ & Cope, 1876 & 138 & & & Nomen nudum & L ACU & No type & \\
\hline \multirow{10}{*}{$\begin{array}{l}\text { Hourglass dolphin } \\
\text { - Lagenorbynchus } \\
\text { cruciger }\end{array}$} & Delphinus cruciger & Quoy \& Gaimard, 1824 & 87 & $\mathrm{x}$ & $\mathrm{X}$ & Valid name & L CRU & MNHN? & \\
\hline & Delphinus albigena & Quoy \& Gaimard, 1824 & 87 & $\mathrm{X}$ & & Junior synonym & L CRU & No type? & \\
\hline & Delphinus bivittatus & $\begin{array}{l}\text { Lesson \& Garnot, } 1827 \\
\text { (Lesson in) }\end{array}$ & 178, pl. 9 & $\mathrm{x}$ & & Junior synonym & L CRU & No type & \\
\hline & Phocaena homeii & Smith, 1829 & 440 & $\mathrm{X}$ & & Junior synonym & L CRU & SAM & \\
\hline & Lagenorhynchus clanculus & Gray, 1846 & Pl. 35 & $\mathrm{X}$ & & Junior synonym & L CRU & NHMUK & \\
\hline & Delphinus obscurus & Gray, 1850 & 107 & $\mathrm{X}$ & & Junior synonym & L CRU & MNHN? & \\
\hline & Electra clancula & Gray, $1868 \mathrm{a}$ & 7 & $\mathrm{x}$ & & Junior synonym & L CRU & NHMUK & $\begin{array}{l}\text { Senior homonym of Electra } \\
\text { clancula Hector, } 1872\end{array}$ \\
\hline & Lagenorhynchus latifrons & True, 1889 & 84 & & & Nomen nudum & L CRU & MNHN? & \\
\hline & Phocaena d'orbignyi & Philippi, 1893 & 10 & $\mathrm{X}$ & & Junior synonym & L CRU & No type? & \\
\hline & Lagenorhynchus wilsoni & Lillie, 1915 & 123 & $\mathrm{X}$ & & Junior synonym & L CRU & No type & \\
\hline \multirow[t]{9}{*}{$\begin{array}{l}\text { Dusky dolphin - } \\
\text { Lagenorhynchus } \\
\text { obscurus }\end{array}$} & $\begin{array}{l}\text { Delphinus (Grampus) } \\
\text { obscurus }\end{array}$ & Gray, 1828 & 2 & $\mathrm{x}$ & $\mathrm{x}$ & Valid name & L OBS & NHMUK & \\
\hline & Delphinus fitzroyi & Waterhouse, 1838a,b & 23 & $\mathrm{X}$ & & Junior synonym & L OBS & NHMUK & \\
\hline & Delphinus breviceps & Wiegmann, 1840 & Pl. 368 & $\mathrm{X}$ & & Junior synonym & L OBS & No type & No description \\
\hline & Delphinus breviceps & $\begin{array}{l}\text { Jacquinot \& Pucheran, } \\
1853\end{array}$ & 39 & $\mathrm{X}$ & & Junior synonym & L OBS & MNHN & \\
\hline & Clymene similis & Gray, 1868b & 146 & $\mathrm{x}$ & & Junior synonym & L OBS & NHMUK & $\begin{array}{l}\text { Type specimen ID is } \\
\text { uncertain }\end{array}$ \\
\hline & Prodelphinus petersii & $\begin{array}{l}\text { Lütken, } 1889 \\
\text { (Reinhardt in) }\end{array}$ & 43 & $\mathrm{X}$ & & Junior synonym & L OBS & NHMD & \\
\hline & Phocaena posidonia & Philippi, 1893 & 9 & $\mathrm{X}$ & & Junior synonym & L OBS & \begin{tabular}{|l|} 
NHM, \\
Santiago \\
\end{tabular} & $\begin{array}{l}\text { Some have considered a } \\
\text { nomen dubium }\end{array}$ \\
\hline & Tursio? panope & Philippi, 1895 & 284 & $\mathrm{X}$ & & Junior synonym & L OBS & \begin{tabular}{|l|} 
NHM, \\
Santiago
\end{tabular} & See Canto, 2014 for history \\
\hline & [Lagenorhynchus] thicolea & Trouessart, 1899 & 1038 & $\mathrm{X}$ & & Junior synonym & L OBS & NHMUK & Questions about identity?? \\
\hline \multirow{4}{*}{$\begin{array}{l}\text { Peale's dolphin- } \\
\text { Lagenorhynchus } \\
\text { australis }\end{array}$} & Phocoena australis & Peale, 1849 & 33 & $\mathrm{x}$ & $\mathrm{x}$ & Valid name & L AUS & USNM - lost? & \\
\hline & Delphinus obscurus (in part) & Cassin, 1858 & 27 & $\mathrm{X}$ & & Junior synonym & L AUS & USNM? & \\
\hline & Sagmatias amblodon & Cope, 1866 & 294 & $\mathrm{X}$ & & Junior synonym & L AUS & USNM & \\
\hline & Tursio chiloensis & Philippi, 1900 & 10 & $\mathrm{x}$ & & Junior synonym & L AUS & \begin{tabular}{|l|} 
NHM, \\
Santiago \\
\end{tabular} & \\
\hline \multirow[t]{3}{*}{$\begin{array}{l}\text { Pacific white-sided } \\
\text { dolphin - Lagenorbyn- } \\
\text { chus obliquidens }\end{array}$} & Lagenorhynchus obliquidens & Gill, 1865 & 177 & $\mathrm{x}$ & $\mathrm{x}$ & Valid name & L OBL & USNM & \\
\hline & Delphinus longidens & Cope, 1866 & 295 & $\mathrm{X}$ & & Junior synonym & L OBL & USNM & \\
\hline & Lagenorhynchus ognevi & Sleptsov, 1955 & 60 & $\mathrm{x}$ & & Junior synonym & L OBL & \begin{tabular}{|l} 
Zool Mus, \\
Moscow State \\
Univ \\
\end{tabular} & \\
\hline \multirow[t]{2}{*}{$\begin{array}{l}\text { Southern right whale } \\
\text { dolphin - Lissodelphis } \\
\text { peronii }\end{array}$} & Delphinus peronii & Lacépède, 1804 & 316 & $\mathrm{X}$ & $\mathrm{x}$ & Valid name & L PER & MNHN? & \\
\hline & Delphinus leucorhampus & $\begin{array}{l}\text { Lacépède, } 1804 \text { (Peron } \\
\text { in) }\end{array}$ & 316 & $\mathrm{X}$ & & Junior synonym & L PER & No type & $\begin{array}{l}\text { Description from specimens } \\
\text { observed at sea }\end{array}$ \\
\hline
\end{tabular}




\begin{tabular}{|c|c|c|c|c|c|c|c|c|c|}
\hline Current species & Nominal species & Authority & Page \# & Avail? & Valid? & Status & SPEC & Type dispos. & Notes \\
\hline & D[elphinus] bicolor & Gray, 1846 & 36 & & & Junior synonym & L PER & $?$ & \\
\hline & Delphinapterus lessonii & Philippi, 1893 & 17 & $\mathrm{X}$ & & Junior synonym & L PER & No type? & $\begin{array}{l}\text { No description in Philippi } \\
\text { (1893)? }\end{array}$ \\
\hline & Prodelphinus gervaisi & Trouessart, 1899 & 1036 & $\mathrm{X}$ & & Junior synonym & L PER & No type? & \\
\hline \multirow[t]{2}{*}{$\begin{array}{l}\text { Northern right whale } \\
\text { dolphin - Lissodelphis } \\
\text { borealis }\end{array}$} & Lagenorhynchus thicolea & Gray, 1846 & Pl. 36 & $\mathrm{X}$ & & Nomen oblitum & L BOR & NHMUK & $\begin{array}{l}\text { Some question the accuracy } \\
\text { of the collection locality, } \\
\text { which would make this } \\
\text { name a nomen dubium }\end{array}$ \\
\hline & Delphinapterus borealis & Peale, 1849 & 35 & $\mathrm{X}$ & $\mathrm{X}$ & Nomen protectum & L BOR & USNM-Lost & \\
\hline \multirow{3}{*}{$\begin{array}{l}\text { Commerson's dolphin } \\
\text { - Cephalorhynchus } \\
\text { commersonii }\end{array}$} & Delphinus commersonii & Lacépède, 1804 & 317 & $\mathrm{X}$ & $\mathrm{X}$ & Valid name & $\mathrm{C} \mathrm{COM}$ & No type? & \\
\hline & Lagenorhynchus floweri & Moreno, 1892 & 385 & $\mathrm{X}$ & & Junior synonym & $\mathrm{C} \mathrm{COM}$ & MLP & \\
\hline & $\begin{array}{l}\text { L[agenorhynchus] } \\
\text { burmeisteri }\end{array}$ & Moreno, 1892 & 390 & $\mathrm{X}$ & & Junior synonym & $\mathrm{C} \mathrm{COM}$ & No type & \\
\hline \multirow[t]{7}{*}{$\begin{array}{l}\text { Heaviside's dolphin } \\
\text { - Cephalorhynchus } \\
\text { heavisidii }\end{array}$} & $\begin{array}{l}\text { Delphinus (Grampus) } \\
\text { heavisidii }\end{array}$ & Gray, 1828 & 2 & $\mathrm{X}$ & $\mathrm{X}$ & Valid name & C HEA & NHMUK & \\
\hline & D[elphinus] capensis & $\begin{array}{l}\text { Cuvier, } 1829 \text { (Dussum- } \\
\text { ier in) }\end{array}$ & 289 & $\mathrm{X}$ & & Junior synomym & C HEA & MNHN & \\
\hline & Delphinus dussumieri & Fischer, 1829 & 656 & $\mathrm{X}$ & & Junior homonym & C HEA & MNHN? & \\
\hline & Delphinus cephalorhynchus & F. Cuvier, 1836 & 158 & $\mathrm{X}$ & & Junior synonym & C HEA & MNHN? & \\
\hline & Delphinus hastatus & F. Cuvier, 1836 & 161 & $\mathrm{X}$ & & Junior synonym & C HEA & $?$ & \\
\hline & Delphinus tridens & $\begin{array}{l}\text { P. J. Van Beneden, } 1873 \\
\text { (Castelnau in) }\end{array}$ & 33 & $\mathrm{X}$ & & Junior synomym & C HEA & $?$ & \\
\hline & Orca capensis & P. J. Van Beneden, 1873 & 32 & $\mathrm{X}$ & & $\begin{array}{l}\text { Junior } \\
\text { homonym }\end{array}$ & C HEA & $?$ & $\begin{array}{l}\text { Junior homonym of Orca } \\
\text { capensis Gray, } 1846\end{array}$ \\
\hline \multirow[t]{5}{*}{$\begin{array}{l}\text { Chilean dolphin - } \\
\text { Cephalorbynchus } \\
\text { eutropia }\end{array}$} & Delphinus lunatus & Lesson, 1826 & 373 & $\mathrm{X}$ & & Nomen oblitum & C EUT & No type? & $\begin{array}{l}\text { No type collected; described } \\
\text { from specimens seen at sea; } \\
\text { see Goodall et al. (1988), } \\
\text { p. } 205\end{array}$ \\
\hline & Delphinus eutropia & Gray, 1846 & Pl. 34 & $\mathrm{X}$ & $\mathrm{X}$ & $\begin{array}{l}\text { Nomen } \\
\text { protectum }\end{array}$ & C EUT & NHMUK & \\
\hline & Eutropia dickiei & Gray, 1866b & 215 & $\mathrm{X}$ & & Junior synonym & C EUT & No type? & \\
\hline & $\begin{array}{l}\text { Phocaena (Hyperoodon?) } \\
\text { albiventris }\end{array}$ & $\begin{array}{l}\text { Philippi, } 1893 \text { (Perez } \\
\text { Canto in) }\end{array}$ & 227 & $\mathrm{X}$ & & Junior synonym & C EUT & $\begin{array}{l}\text { NHM, } \\
\text { Santiago }\end{array}$ & \\
\hline & Tursio? platyrrbinus & Philippi, 1895 & 16 & $\mathrm{X}$ & & Junior synonym & C EUT & $\begin{array}{l}\text { NHM, } \\
\text { Santiago }\end{array}$ & \\
\hline \multirow[t]{3}{*}{$\begin{array}{l}\text { Hector's dolphin - } \\
\text { Cephalorbynchus } \\
\text { bectori }\end{array}$} & Electra clancula & Hector, 1873 & 160 & & & Junior homonym & C HEC & $\begin{array}{l}\text { Colonial Mus, } \\
\text { Wellington }\end{array}$ & $\begin{array}{l}\text { Junior homonym of Electra } \\
\text { clancula Gray, 1868; type } \\
\text { description contains mix } \\
\text { of Cephalorhynchus hec- } \\
\text { tori and Lagenorhynchus } \\
\text { obscurus }\end{array}$ \\
\hline & Electra hectori & P. J. Van Beneden, 1881 & 882 & $\mathrm{X}$ & $\mathrm{X}$ & Valid name & C HEC & $\begin{array}{l}\text { Louvain Mus, } \\
\text { Brussels }\end{array}$ & $\begin{array}{l}\text { Type possibly in Mus Roy } \\
\text { d'Hist Nat, Brussells }\end{array}$ \\
\hline & Cephalorhynchus albifrons & True, 1889 & 111 & $\mathrm{X}$ & & Junior synonym & C HEC & No type? & \\
\hline \multirow[t]{2}{*}{$\begin{array}{l}\text { Dall's porpoise - } \\
\text { Phocoenoides dalli }\end{array}$} & Phocaena dalli & True, 1885 & 95 & $\mathrm{X}$ & $\mathrm{X}$ & Valid name & P DAL & USNM & \\
\hline & Phocoenoides truei & Andrews, 1911b & 32 & $\mathrm{X}$ & & Junior synonym & P DAL & AMNH & \\
\hline \multirow[t]{6}{*}{$\begin{array}{l}\text { Harbor porpoise - } \\
\text { Phocoena phocoena }\end{array}$} & Delphinus phocoena & Linnaeus, 1758 & 77 & $\mathrm{X}$ & $\mathrm{X}$ & Valid name & P PHO & No type & \\
\hline & $D$ [elphinus] phocaena fuscus & Kerr, 1792 & 363 & $\mathrm{X}$ & & $\begin{array}{l}\text { Not a species } \\
\text { name }\end{array}$ & P PHO & No type? & Subspecies/variety name \\
\hline & Delphinus ventricosus & Lacépède, 1804 & 311 & $\mathrm{X}$ & & Junior synonym & P PHO & No type? & \\
\hline & Phocaena communis & Lesson, 1827 & 413 & $\mathrm{X}$ & & Junior synonym & P PHO & No type & \\
\hline & Phocaena tuberculifera & Gray, 1865b & 320 & $\mathrm{X}$ & & Junior synonym & P PHO & NHMUK & \\
\hline & Phocoena vomerina & Gill, 1865 & 178 & $\mathrm{X}$ & & Junior synonym & P PHO & USNM & \\
\hline
\end{tabular}




\begin{tabular}{|c|c|c|c|c|c|c|c|c|c|}
\hline Current species & Nominal species & Authority & Page \# & Avail? & Valid? & Status & SPEC & Type dispos. & Notes \\
\hline & Phocaena brachycium & Cope, 1865 a & 279 & $\mathrm{X}$ & & Junior synonym & P PHO & $\begin{array}{l}\text { Mus Essex } \\
\text { Inst, Salem }\end{array}$ & \\
\hline & Phocaena americana & J. A. Allen, 1869 & 206 & $\mathrm{X}$ & & Junior synonym & P PHO & No type? & \\
\hline & Phocoena rondeletti & Giglioli, 1870 & 78 & $\mathrm{X}$ & & Junior synonym & P PHO & No type? & \\
\hline & Phocaena lineata & Cope, 1876 & 134 & $\mathrm{X}$ & & Junior synonym & P PHO & USNM & \\
\hline & Phocoena relicta & Abel, 1905 & 388 & $\mathrm{X}$ & & Junior synonym & P PHO & $\begin{array}{l}\text { Acad Sci, } \\
\text { Sebastopol, } \\
\text { Russia }\end{array}$ & \\
\hline \multirow[t]{2}{*}{$\begin{array}{l}\text { Burmeister's porpoise - } \\
\text { Phocoena spinipinnis }\end{array}$} & Phocaena spinipinnis & Burmeister, 1865a,b & 228 & $\mathrm{X}$ & $\mathrm{X}$ & Valid name & P SPI & $\begin{array}{l}\text { MACN-Ma } \\
\text {-Skull lost } \\
\text { (mounted skin } \\
\text { still present) }\end{array}$ & \\
\hline & Phocaena philippii & Philippi, 1893 & 9 & $\mathrm{X}$ & & Junior synonym & P SPI & No type? & \\
\hline \multirow[t]{2}{*}{$\begin{array}{l}\text { Spectacled porpoise - } \\
\text { Phocoena dioptrica }\end{array}$} & Phocoena dioptrica & Lahille, 1912 & 271 & $\mathrm{X}$ & $\mathrm{X}$ & Valid name & P DIO & $\begin{array}{l}\text { Adult lost, } \\
\text { but fetus at } \\
\text { MACN-Ma }\end{array}$ & \\
\hline & Phocaena stornii & Marelli, 1922 & 229 & $\mathrm{X}$ & & Junior synonym & P DIO & MACN-Ma & \\
\hline $\begin{array}{l}\text { Vaquita-Phocoena } \\
\text { sinus }\end{array}$ & Phocoena sinus & $\begin{array}{l}\text { Norris \& McFarland, } \\
1958\end{array}$ & 24 & $\mathrm{X}$ & $\mathrm{X}$ & Valid name & P SIN & MVZ & \\
\hline \multirow{3}{*}{$\begin{array}{l}\text { Indo-Pacific finless por- } \\
\text { poise-Neophocaena } \\
\text { phocaenoides }\end{array}$} & Delphinus phocaenoides & G. Cuvier, 1829 & 291 & $\mathrm{X}$ & $\mathrm{X}$ & Valid name & N PHO & MNHN & \\
\hline & Delphinapterus molagan & Owen, 1866 & 24 & $\mathrm{X}$ & & Junior synonym & N PHO & No type? & \\
\hline & Neomeris kurrachiensis & Murray, 1884 & 351 & $\mathrm{X}$ & & Junior synonym & NPHO & $\begin{array}{l}\text { Kurrachee } \\
\text { Mus }\end{array}$ & \\
\hline \multirow{3}{*}{$\begin{array}{l}\text { Narrow-ridged finless } \\
\text { porpoise-Neopho- } \\
\text { caena asiaeorientalis }\end{array}$} & Delphinus melas & Schlegel, 1841b & 32 & $\mathrm{X}$ & & Junior homonym & N ASI & RMNH & $\begin{array}{l}\text { Junior homonym of Delphi- } \\
\text { nus melas Traill, } 1809\end{array}$ \\
\hline & Neomeris asiaeorientalis & Pilleri \& Gihr, 1972a & 118 & $\mathrm{X}$ & $\mathrm{X}$ & Valid name & N ASI & MCZ & \\
\hline & Neophocaena sunameri & Pilleri \& Gihr, 1975 & 668 & $\mathrm{X}$ & & Junior synonym & N ASI & RMNH & \\
\hline \multirow[t]{5}{*}{$\begin{array}{l}\text { South Asian river } \\
\text { dolphin - Platanista } \\
\text { gangetica }\end{array}$} & Delphinus gangeticus & Lebeck, 1801 & 280 & $\mathrm{X}$ & $\mathrm{X}$ & Valid name & P GAN & $\begin{array}{l}\text { Destroyed - } \\
\text { cast of man- } \\
\text { dible/rostrum } \\
\text { at NHMUK }\end{array}$ & $\begin{array}{l}\text { Senior homonym of Delphi- } \\
\text { nus gangeticus Roxburgh, } \\
1801\end{array}$ \\
\hline & Delphinus gangeticus & Roxburgh, 1801 & 171 & $\mathrm{X}$ & & Junior synonym & P GAN & $\begin{array}{l}\text { Destroyed } \\
\text {-cast of man- } \\
\text { dible/rostrum } \\
\text { at NHMUK }\end{array}$ & $\begin{array}{l}\text { Also, a junior homonym } \\
\text { of Delphinus gangeticus } \\
\text { Lebeck, } 1801\end{array}$ \\
\hline & Susu platanista & Lesson, 1828 & 440 & & & Nomen nudum & P GAN & No type & \\
\hline & Platanista minor & Owen, 1853 & 448 & $\mathrm{X}$ & & Junior synonym & P GAN & $\begin{array}{l}\text { Hunterian } \\
\text { Museum }\end{array}$ & \\
\hline & Platanista indi & Blyth, 1859 & 493 & $\mathrm{X}$ & & Junior synonym & P GAN & $\begin{array}{l}\text { Indian Muse- } \\
\text { um, Calcutta }\end{array}$ & $\begin{array}{l}\text { There is a neotype in the } \\
\text { SMNS, Stuttgart }\end{array}$ \\
\hline \multirow[t]{7}{*}{$\begin{array}{l}\text { Boto or Amazon } \\
\text { river dolphin - Inia } \\
\text { geoffrensis }\end{array}$} & Delphinus rostratus & Shaw, 1801 & 514 & $\mathrm{X}$ & & Nomen oblitum & I GEO & NHMUK & $\begin{array}{l}\text { Questionable species iden- } \\
\text { tity - see Smeenk (2018) } \\
\text { for details }\end{array}$ \\
\hline & Delphinus geoffrensis & $\begin{array}{l}\text { Desmarest, } 1817 \text { (Bla- } \\
\text { inville in) }\end{array}$ & 151 & $\mathrm{X}$ & $\mathrm{X}$ & Nomenprotectum & I GEO & MNHN & \\
\hline & Delphinus shawensis & $\begin{array}{l}\text { Desmarest, } 1817 \text { (Bla- } \\
\text { inville in) }\end{array}$ & 153 & $\mathrm{X}$ & & Junior synonym & I GEO & $\begin{array}{l}\text { Hunterian } \\
\text { Museum }\end{array}$ & \\
\hline & [Delphinus] frontatus & G. Cuvier, 1823 & 278 & $\mathrm{X}$ & & Junior synonym & I GEO & MNHN? & $\begin{array}{l}\text { Possibly based on composite } \\
\text { material }\end{array}$ \\
\hline & Delphinus amazonicus & $\begin{array}{l}\text { von Spix \& von Martius, } \\
1831\end{array}$ & 1118 & $\mathrm{X}$ & & Junior synonym & I GEO & Lost? & \\
\hline & Inia boliviensis & D’Orbigny, 1834 & 31 & $\mathrm{X}$ & & Junior synonym & I GEO & MNHN & \\
\hline & Delphinus inia & Rapp, 1837 & 42 & $\mathrm{X}$ & & Junior synonym & I GEO & No type? & \\
\hline
\end{tabular}




\begin{tabular}{|c|c|c|c|c|c|c|c|c|c|}
\hline Current species & Nominal species & Authority & Page \# & Avail? & Valid? & Status & SPEC & Type dispos. & Notes \\
\hline & Inia araguaiaensis & Hrbek et al., 2014 & 8 & $\mathrm{x}$ & & Junior synonym & I GEO & \begin{tabular}{|l|} 
National Re- \\
search Institute \\
of the Amazon \\
\end{tabular} & \\
\hline \multirow[t]{2}{*}{$\begin{array}{l}\text { Franciscana-Pontopo- } \\
\text { ria blainvillei }\end{array}$} & Delphinus blainvillei & $\begin{array}{l}\text { Gervais \& d'Orbigny, } \\
1844\end{array}$ & 39 & $\mathrm{X}$ & $\mathrm{X}$ & Valid name & P BLA & MNHN & \begin{tabular}{|l} 
Or d'Orbigny, \\
$1839: 31$ \\
\end{tabular} \\
\hline & Pontoporia tenuirostris & Malm, 1871 & 46 & $\mathrm{x}$ & & Junior synonym & P BLA & $\begin{array}{l}\text { Goteborg Nat } \\
\text { Mus, Sweden }\end{array}$ & \\
\hline Baiji - Lipotes vexillifer & Lipotes vexillifer & Miller, 1918 & 2 & $\mathrm{X}$ & $\mathrm{X}$ & Valid name & L VEX & USNM & \\
\hline \multirow[t]{32}{*}{ Incertae sedis } & Monodon spurius & Fabricius, 1780 & 31 & $\mathrm{x}$ & & Nomen dubium & UNKN & No type? & $\begin{array}{l}\text { Probably Monodon } \\
\text { monoceros }\end{array}$ \\
\hline & Delphinus tursio & Fabricius, 1780 & 49 & $\mathrm{X}$ & & Nomen dubium & UNKN & No type? & $\begin{array}{l}\text { Junior homonym of Delphi- } \\
\text { nus tursio Gunnerus, } 1768\end{array}$ \\
\hline & D[elphinus] feres & Bonnaterre, 1789 & 27 & $\mathrm{x}$ & & Nomen dubium & UNKN & $\begin{array}{l}\text { Mus Seminary } \\
\text { of Frejus }\end{array}$ & \\
\hline & Delphinapterus senedetta & Lacépède, 1804 & 249 & $\mathrm{X}$ & & Nomen dubium & UNKN & No type? & \\
\hline & Anarnak groenlandicus & Lacépède, 1804 & 164 & $\mathrm{x}$ & & Nomen dubium & UNKN & No type? & $\begin{array}{l}\text { Probably Monodon } \\
\text { monoceros }\end{array}$ \\
\hline & $D$ [elphinus] bonnaterrei & Tiedemann, 1808 & 583 & $\mathrm{X}$ & & Nomen dubium & UNKN & No type? & \\
\hline & Delphinus siculus & $\begin{array}{l}\text { Rafinesque Schmaltz, } \\
1810\end{array}$ & 5 & $\mathrm{x}$ & & Nomen dubium & UNKN & $?$ & \\
\hline & $D[$ elphinus $]$ dubius & G. Cuvier, 1812 & 14 & $\mathrm{x}$ & & Nomen dubium & UNKN & MNHN & $\begin{array}{l}\text { Name from a composite of } \\
\text { both spotted dolphins }\end{array}$ \\
\hline & [Delphinus] coronatus & Freminville, 1812 & 71 & $\mathrm{x}$ & & Nomen dubium & UNKN & No type? & \\
\hline & Delphimus pernettensis & $\begin{array}{l}\text { Desmarest, } 1817 \text { (Bla- } \\
\text { inville in) }\end{array}$ & 154 & $\mathrm{x}$ & & Nomen oblitum & UNKN & No type & $\begin{array}{l}\text { Suppressed by ICZN; prob- } \\
\text { ably Stenella attenuate or } \\
\text { Stenella frontalis }\end{array}$ \\
\hline & Delphinus bertini & $\begin{array}{l}\text { Desmarest, } 1817 \text { (Du- } \\
\text { hamel in) }\end{array}$ & 163 & $\mathrm{x}$ & & Nomen dubium & UNKN & $?$ & \\
\hline & Delphinus niger & Lacépède, 1818 & 475 & $\mathrm{X}$ & & Nomen dubium & UNKN & No type? & \\
\hline & Delphinus boryi & Desmarest, 1822 & 513 & $\mathrm{X}$ & & Nomen dubium & UNKN & No type? & \\
\hline & Delphinus anarnacus & Desmarest, 1822 & 520 & $\mathrm{x}$ & & Nomen dubium & UNKN & No type? & \\
\hline & Delphinus epiodon & Desmarest, 1822 & 521 & $\mathrm{X}$ & & Nomen dubium & UNKN & No type? & \\
\hline & Delphinus rhinoceros & Quoy \& Gaimard, 1824 & 86 & $\mathrm{X}$ & & Nomen dubium & UNKN & No type & Not likely a cetacean \\
\hline & Delphinus leucocephalus & Lesson, 1826 & 373 & $\mathrm{X}$ & & Nomen dubium & UNKN & No type? & \\
\hline & Delphinus malayanus & Lesson, 1826 & 373 & $\mathrm{x}$ & & Nomen dubium & UNKN & No type & $\begin{array}{l}\text { Probably Sousa plumbea - } \\
\text { see van Bree, } 1986\end{array}$ \\
\hline & Delphinus minimus & Lesson \& Garnot, 1827 & 185 & $\mathrm{x}$ & & Nomen dubium & UNKN & No type? & \\
\hline & Delphinus maculatus & Lesson \& Garnot, 1827 & 183 & $\mathrm{X}$ & & Nomen dubium & UNKN & No type? & \\
\hline & Delphinus superciliosus & Lesson \& Garnot, 1827 & 181 & $\mathrm{x}$ & & Nomen dubium & UNKN & Type lost? & $\begin{array}{l}\text { There are questions about } \\
\text { identity of type specimen, } \\
\text { possibly a dusky or hour- } \\
\text { glass dolphin }\end{array}$ \\
\hline & Delphinus nesarnac & Lesson, 1827 & 408 & $\mathrm{X}$ & & Nomen dubium & UNKN & $?$ & \\
\hline & [Delphinus] fabricii & Billberg, 1827 & 34 & $\mathrm{x}$ & & Nomen dubium & UNKN & $?$ & $\begin{array}{l}\text { Possibly a synonym of } \\
\text { Tursiops truncatus } \\
\end{array}$ \\
\hline & C[atodon] sibbaldi & Fleming, 1828 & 39 & $\mathrm{x}$ & & Nomen dubium & UNKN & No type? & May be a beluga \\
\hline & Delphinus harlani & Fischer, 1829 & $656(456)$ & $\mathrm{X}$ & & Nomen dubium & UNKN & $?$ & \\
\hline & \begin{tabular}{|l|}
$\begin{array}{l}\text { Delphinorhynchus } \\
\text { santonicus }\end{array}$ \\
\end{tabular} & Lesson, 1836 & 330 & $\mathrm{x}$ & & Nomen dubium & UNKN & No type & $\begin{array}{l}\text { Previously considered a syn- } \\
\text { onym of Steno bredanensis }\end{array}$ \\
\hline & Delphinus fulvifasciatus & Wiegmann, 1840 & Pl. 361 & $\mathrm{X}$ & & Nomen dubium & UNKN & No type & No description \\
\hline & Delphinus carbonarius & Wiegmann, 1844 & Pl. 352 & $\mathrm{x}$ & & Nomen dubium & UNKN & No type & $\begin{array}{l}\text { Probably a pilot whale, } \\
\text { Globicephala sp. }\end{array}$ \\
\hline & Delphinus rappii & Reichenbach, 1846 & 117 & $\mathrm{x}$ & & Nomen dubium & UNKN & $\begin{array}{l}\text { Stuttgart } \\
\text { Museum }\end{array}$ & \\
\hline & Delphinus sao & Gray, 1846 & 41 & $\mathrm{X}$ & & Nomen dubium & UNKN & MNHN & \\
\hline & $D$ [elphinus] carbonarius & Wagner, 1847 & 305, pl. 352 & $\mathrm{x}$ & & Nomen dubium & UNKN & No type? & \\
\hline & Delphinus perniger & Blyth, 1848 & 250 & $\mathrm{x}$ & & Nomen dubium & UNKN & $\begin{array}{l}\text { Indian Muse- } \\
\text { um, Calcutta }\end{array}$ & Probably Tursiops \\
\hline
\end{tabular}

Table continued 


\begin{tabular}{|c|c|c|c|c|c|c|c|c|c|}
\hline Current species & Nominal species & Authority & Page \# & Avail? & Valid? & Status & SPEC & Type dispos. & Notes \\
\hline & D[elphinus] oxyrhynchus & Gray, 1850 & 131 & $\mathrm{X}$ & & Nomen dubium & UNKN & No type? & Possibly Steno bredanensis \\
\hline & Delphinus obtusus & Schlegel, 1862 & Pl. 13 & $\mathrm{X}$ & & Nomen dubium & UNKN & $?$ & Possibly Tursiops \\
\hline & Lagenorhynchus? nilssonii & Gray, 1864 & 238 & $\mathrm{X}$ & & Nomen dubium & UNKN & $\begin{array}{l}\text { Museum of } \\
\text { Lund }\end{array}$ & $\begin{array}{l}\text { ID questionable; previously } \\
\text { misidentified as Delphinus } \\
\text { obscurus }\end{array}$ \\
\hline & Globicephalus chinensis & Gray, 1866a & 323 & $\mathrm{X}$ & & Nomen dubium & UNKN & No type? & \\
\hline & Delphinus marginatus & Lafont, 1868 & 518 & $\mathrm{X}$ & & Nomen dubium & UNKN & No type? & $\begin{array}{l}\text { Homonym of Delphinus } \\
\text { marginatus Desmarest, } \\
1856 \text { (Duvernoy in) }\end{array}$ \\
\hline & Delphinus caerulescens & Giglioli, 1874 & 88 & $\mathrm{X}$ & & Nomen dubium & UNKN & $?$ & \\
\hline & Phocaena obtusata & Philippi, 1893 & 12 & $\mathrm{X}$ & & Nomen dubium & UNKN & $\begin{array}{l}\text { NHM, } \\
\text { Santiago }\end{array}$ & $\begin{array}{l}\text { Probably Cephalorhynchus } \\
\text { eutropia? }\end{array}$ \\
\hline & Delphinus chilensis & Philippi, 1895 & 283 & $\mathrm{X}$ & & Nomen dubium & UNKN & $?$ & \\
\hline & Lagenorhynchus fitzroyi & Lahille, 1899 & 200 & $\mathrm{X}$ & & Nomen dubium & UNKN & No type? & $\begin{array}{l}\text { Possibly Lagenorhynchus } \\
\text { obscurus }\end{array}$ \\
\hline
\end{tabular}

